\author{
Universidade de São Paulo \\ Faculdade de Filosofia, Letras e Ciências Humanas \\ Programa de Pós-Graduação em História Econômica
}

\title{
ENTRE A HISTÓRIA E A ECONOMIA: O PENSAMENTO ECONÔMICO DE ROBERTO SIMONSEN
}

\author{
Versão Corrigida
}

Luiz Felipe Bruzzi Curi

São Paulo

2014 


\author{
Universidade de São Paulo \\ Faculdade de Filosofia, Letras e Ciências Humanas \\ Programa de Pós-Graduação em História Econômica
}

\title{
ENTRE A HISTÓRIA E A ECONOMIA: O PENSAMENTO ECONÔMICO DE ROBERTO SIMONSEN
}

\author{
Versão Corrigida
}

Luiz Felipe Bruzzi Curi

Dissertação apresentada ao Programa de PósGraduação em História Econômica do Departamento de História da Faculdade de Filosofia, Letras e Ciências Humanas da Universidade de São Paulo, como requisito parcial à obtenção do título de Mestre em História Econômica.

Orientador: Prof. Dr. Alexandre Macchione Saes

De acordo - Prof. Dr. Alexandre Macchione Saes

São Paulo

2014 
Dissertação de Mestrado

Aluno: Luiz Felipe Bruzzi Curi

Título: "Entre a história e a economia: o pensamento econômico de Roberto Simonsen"

Defendida em:

Banca Examinadora

Prof. Dr. Alexandre Macchione Saes

Orientador - Programa de Pós-Graduação em História Econômica/USP

Prof. Dr. Alexandre Mendes Cunha

Cedeplar/UFMG

Prof. Dr. Felipe Pereira Loureiro

IRI/USP 
Ser radical é apreender as coisas na raiz. A raiz do homem, porém, é o próprio homem.

Karl Marx 


\title{
Resumo
}

Esta dissertação versa sobre o pensamento econômico de Roberto Simonsen. A partir de uma perspectiva de reconstituição histórica do pensamento econômico, busca-se compreender a formação do pensamento de Simonsen, levando em conta as instituições que frequentou e sua trajetória como empresário e político. Enfatiza-se a dimensão da participação de Simonsen na difusão internacional de ideias econômicas, adaptando ideias estrangeiras ao contexto brasileiro. Mostra-se que a interpretação que Simonsen dá para a história do Brasil, em seu livro clássico, é muito importante para a construção de seu pensamento econômico, estruturado em torno dos eixos do protecionismo e do planejamento.

\begin{abstract}
This dissertation deals with the economic thought of Roberto Simonsen. From a perspective based on the historical reconstitution of economic thought, we seek to understand the formation of Simonsen's economic thought, taking into account the institutions to which he belonged and his role as a businessman and as a politician. We emphasize Simonsen's participation in the international diffusion of economic ideas, adapting foreign ideas to the Brazilian context. We show that Simonsen's interpretation of Brazilian economic history, present in his classic book, is very important for the construction of his economic thought, structured around two axes: protectionism and economic planning.
\end{abstract}




\section{Agradecimentos}

Este trabalho é o resultado de pesquisa feita no âmbito do Programa de Pós-Graduação em História Econômica da Faculdade de Filosofia, Letras e Ciências Humanas da Universidade de São Paulo, ao longo dos anos de 2012 e 2013, com o apoio da FAPESP. Embora a dissertação leve o nome de apenas um autor, a sua realização não teria sido possível sem a co-laboração - o trabalho conjunto - de várias pessoas que estiveram comigo ao longo desse percurso.

O mestrado significou, para mim, mudar de universidade. O professor Alexandre Saes, o nosso querido Xixo, me acolheu na USP como orientador e amigo, abrindo-me as portas e acompanhando-me pelas veredas da pesquisa com rigor e confiança, sem nunca perder o bom humor e a tranquilidade. Para este trabalho em particular e para meu crescimento intelectual em geral, tem sido fundamental o ambiente de aprendizado conjunto, construído na FEA/USP pelo Xixo e por nós, alunos. E aqui vai meu agradecimento aos companheiros do "Brancaleone", pelas discussões, pelas oportunidades de interlocução e debate de ideias.

A escolha por uma formação em História, que começa a se concretizar com este mestrado, foi amadurecida ainda ao longo do curso de Economia, na UFMG, por incentivo do professor Alexandre Mendes Cunha, que muito tem contribuído para os meus vínculos com o campo da história das ideias econômicas e a quem sou grato por compartilhar comigo, com generosidade e amizade, sua erudição e sua capacidade de trabalho.

Cursar o mestrado na USP envolveu deixar Belo Horizonte para me estabelecer em São Paulo, onde contei com amigos que acabaram se tornando cúmplices dessa empreitada do mestrado. Fui acompanhado na mudança pelo André, o Tenn, a quem agradeço as muitas atitudes de amigo: o esforço em entender o meu jeito de ser, a paciência ao escutar (e debater) meus discursos contra a direita recalcada, a disposição de compartilhar tantas atividades lúdicas e prazerosas comigo. "Para ser historiador, tem que ter suavidade..." - agradeço aqui este e tantos outros conselhos de amigo do Victor, que, além de vibrar com alegria nas vitórias e honrar o nome de Minas, sabe que amizade é estar junto, na história ou na economia, no Horto, no Morumbi ou no Mário Helênio: para o que der e vier. Embora sejamos muitos, São Paulo não se faz só de mineiros - e aqui vai meu muito obrigado ao Gian Spanish, meu mano, que teve a generosidade de me acompanhar e de colaborar comigo em bibliotecas, arquivos, biroscas da Cardeal, grupos de estudo... - e de me ensinar a cortar laranja no bandejão.

Recebi, ao longo da pesquisa, contribuições de professores e colegas, a quem devo muito do que está aqui consignado. Os professores Nelson Nozoe e Felipe Loureiro fizeram valiosas 
observações na qualificação. Meu interlocutor e amigo Danilo Barolo compartilhou comigo sua pesquisa para que juntos fizéssemos um trabalho do qual essa dissertação muito se beneficiou. Os colegas de pesquisa, Roney Cytrynovicz e Beatriz Saes, ajudaram-me a buscar materiais importantes para o trabalho. Deixo ainda um agradecimento especial aos professores Flávio Saes, Gustavo Barros, Carlos Suprinyak e Marco Cavalieri, pelas indicações de leitura e pela enriquecedora troca de ideias, nos fóruns em que estivemos juntos.

Sou grato a todos os que me facilitaram a pesquisa e os trâmites nas instituições às quais este trabalho me levou: bibliotecas da FFLCH, da FEA, do IEB e Arquivo Histórico da Escola Politécnica, na USP; Biblioteca do IFCH/Coleção Roberto Simonsen, na Unicamp; Centro de Documentação (CEDOC), na Escola de Sociologia e Política (ESP-SP). Em especial, agradeço a confiança do Programa de Pós-Graduação em História Econômica da USP, nas pessoas dos docentes e dos colegas, que acolheram meu trabalho, proporcionando-me os meios institucionais e o ambiente acadêmico para realizá-lo. Não poderia deixar de reiterar o fundamental apoio da Fundação de Amparo à Pesquisa do Estado de São Paulo (FAPESP), por meio da concessão da bolsa de mestrado e dos pareceres anônimos enviados, quando da submissão do projeto inicial de pesquisa.

Por fim, agradeço a meus familiares e amigos que vêm acompanhando minha trajetória intelectual há anos: aos meus pais, Thereza Christina e Antônio Celso, pelo esforço em compreender a minha distância e pelo apoio incondicional; à minha irmã Daniella e sua trupe, por encherem as minhas passagens por $\mathrm{BH}$ com alegrias que só crianças são capazes de proporcionar; ao Dart, Lucão, Bernardo Salles, Daniel, Diogo, Thiago Metal, Pirilampo, Douglas, pela cumplicidade e amizade, mesmo em outro estado; ao Bruno e à Bela, pela acolhida em Sampa, antes e depois da minha chegada para ficar; à Camilinha, porque o Rio de Janeiro continua lindo; e, à Paula, minha prima, pela amizade sincera - e por tudo que restou da nossa família. 


\section{SUMÁRIO}

Introdução .................................................................................................................................

Capítulo 1. Roberto Simonsen: da modernização ao pensamento nacional ......................16

1.1. Primeira República e modernização ............................................................................ 18

1.2. Da Revolução de 1930 ao Estado Novo: um novo tipo de atuação................................... 34

Capítulo 2. Nacionalismo, industrialismo e história.....................................................50

2.1. O início da carreira de Simonsen: da Escola Politécnica à FIESP …................................53

2.2. A Escola Livre de Sociologia e Política e a História econômica do Brasil ........................ 84

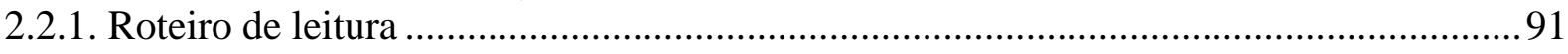

2.2.2. A História econômica do Brasil e o projeto industrialista de Simonsen ...................... 109

2.3. Outras contribuições historiográficas: Aspectos da história econômica do café (1938), Evolução industrial do Brasil (1939) e Recursos econômicos e movimentos das populações

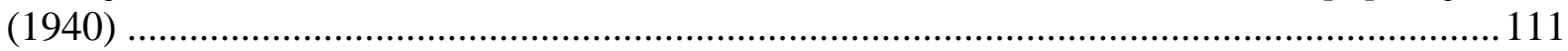

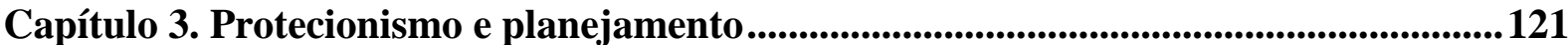

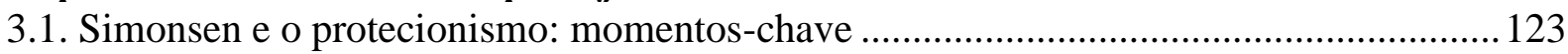

3.1.1. "As finanças e a indústria": Manoilescu e Woytinsky ............................................... 128

3.1.2. O Tratado Comercial de 1935 e a participação de Simonsen ....................................... 141

3.2. Planejamento: a controvérsia, antecedentes e contexto............................................... 159

3.3. O pós-guerra e algumas questões latino-americanas .................................................... 187

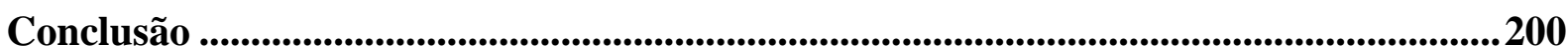

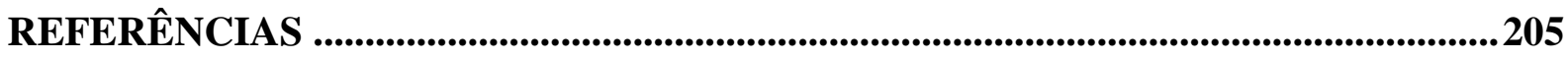

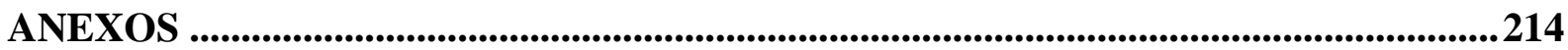




\section{Lista de abreviaturas}

AC-SP: Associação Comercial de São Paulo

CFCE: Conselho Federal de Comércio Exterior

CIB: Centro Industrial do Brasil

CIESP: Centro das Indústrias do Estado de São Paulo

CIFTSP: Centro das Indústrias de Fiação e Tecelagem de São Paulo

CME: Coordenação de Mobilização Econômica

CNPIC: Conselho Nacional de Política Industrial e Comercial

CPE: Comissão de Planejamento Econômico

CREAI: Carteira de Crédito Agrícola e Industrial

DASP: Departamento Administrativo do Serviço Público

ELSP: Escola Livre de Sociologia e Política

FIESP: Federação das Indústrias do Estado de São Paulo

IDORT: Instituto de Organização Racional do Trabalho

PSD: Partido Social-Democrático

SAIN: Sociedade Auxiliadora da Indústria Nacional

SPA: Sociedade Paulista de Agricultura

SUMOC: Superintendência de Moeda e Crédito

UDN: União Democrática Nacional

Abreviaturas de publicações de Roberto Simonsen:

$M P$ : Á margem de profissão (1930)

$H E B$ : História econômica do Brasil (1937)

ESPE: Ensaios sociais, políticos e econômicos (1943)

EIB: Evolução industrial do Brasil e outros estudos (org. de Edgard Carone, 1973) 


\section{Introdução}

A evolução industrial do Brasil. Roberto C. Simonsen. Setembro, 1939 (São Paulo). Sintese interessante e informativa. É um trabalho muito sumário, mas único no assunto. Seu autor fala com a autoridade e experiência de um dos grandes industriais brasileiros.

(Caio Prado Júnior, História econômica do Brasil (1945), bibliografia comentada)

Por suas contribuições historiográficas e por suas ideias econômicas, Roberto Simonsen é um importante intérprete do Brasil. Foi um intérprete que esteve não apenas entre a história e a economia, mas também entre a liderança industrialista e a elaboração intelectual, entre a esfera empresarial privada e a discussão de políticas estatais, entre o apoio à causa paulista e a adesão ao regime Vargas - foi, portanto, um pensador brasileiro de características singulares. O Brasil, dos anos 1910 aos anos 1940, foi o tema central das reflexões de Simonsen. Há textos de cunho mais técnico, ligados a discussões de engenharia civil ou voltados para a administração da produção, mas as contribuições mais relevantes de Simonsen certamente se relacionam às tentativas de se pensar o Brasil em perspectivas novas, isto é, em moldes condizentes com o país que se transformava com a industrialização e a superação do modelo primário-exportador.

Simonsen viveu um dilema, comum a pensadores brasileiros, de pensar sobre um país, ou nação, que se formou externamente, como colônia subordinada aos interesses de uma metrópole. O período em que viveu Simonsen - grosso modo, a primeira metade do século XX - foi marcado por transformações econômicas e sociais, trazidas pela industrialização, e também por uma profusão de movimentos culturais e investigações intelectuais que muito contribuíram para que fosse "inventado" o Brasil que somos hoje. Boa parte desses movimentos - o modernismo da Semana de 1922 é emblemático - procurou resolver de alguma forma essa tensão entre o forâneo e o genuíno, o exterior e o puramente nacional, as "ideias fora do lugar" e a criatividade nativa. A questão, no entanto, é complexa: onde identificar o genuinamente nacional se a "nação" em questão é formada como extensão de uma outra?

Nesse sentido, uma reflexão sobre qualquer processo social que aconteça nessa nação "incompleta" ou em processo de constituição leva a que se pense sobre a formação dessa nação, isto é, sobre o processo de colonização e todas as suas consequências. Simonsen se deparava com problemas relacionados à indústria brasileira: por que não tínhamos o mesmo grau de avanço industrial dos Estados Unidos? A resposta a essa pergunta passaria, no seu caso, por um estudo da história do Brasil. A problemática do atraso no desenvolvimento industrial levou Simonsen a construir uma interpretação da nossa história colonial, a buscar na colonização as raízes do atraso visto em seu tempo presente. Nesse sentido, Simonsen não é 
diferente de contemporâneos seus, como Gilberto Freyre, Sergio Buarque de Holanda, Caio Prado Jr. e Celso Furtado, cujas obras publicadas nos anos 1930 e 1940 voltaram à colonização para explicar aspectos econômicos e sociológicos da formação da nação brasileira. $^{1}$

A construção de uma interpretação da história foi constitutiva do pensamento econômico de Simonsen, na medida em que lhe permitiu constatar que o protecionismo industrial, por exemplo, que não era tido como benéfico por toda uma corrente de economistas, fora uma realidade: países industrializados foram protecionistas, quando se viram diante do desafio de desenvolver suas indústrias. Para além disso, a ideia de que o desenvolvimento econômico é um processo histórico abre margem para uma mudança estrutural como a industrialização induzida, ou planejada, o que não era possível quando se partia do pressuposto de que o Brasil tinha de se aferrar às suas dotações naturais, mantendo-se um país agroexportador.

Simonsen foi buscar na colônia as origens dos entraves que o preocupavam - e também fez seu próprio processo de apropriação de ideias estrangeiras. Seu pensamento econômico se estruturou a partir de múltiplas referências, nem sempre provenientes de uma mesma matriz de pensamento. Na tensão entre o forâneo e o "nacional", numa nação formada externamente, Simonsen contribuiu para a formação de um pensamento econômico brasileiro, por sua apropriação seletiva e criativa de ideias de difusão internacional, por suas tentativas de articular os processos históricos com as formas de pensar a economia. É nesse sentido que esta dissertação pretende contribuir: reconstituir historicamente o pensamento de Simonsen é, de alguma forma, buscar os traços de um pensamento econômico que se possa chamar de brasileiro.

\section{$\underline{\text { Historiografia e questões metodológicas }}$}

"Fazendo-se justiça ao senador Roberto Simonsen, pode-se afirmar que, com a sua morte, o país perde um de seus mais resolutos propugnadores do seu progresso moral, social e material". ${ }^{2}$ Roberto Simonsen faleceu cercado de uma aura de grande homem, o que gerou uma série de textos elogiosos à sua pessoa e à sua obra, como a biografia apresentada pela Folha da Manhã, publicada por ocasião de seu falecimento. Roberto Simonsen foi um personagem marcante entre as décadas de 1910 e 1940, no cenário econômico e político brasileiro. Por sua atuação como industrial e líder classista, pela obra que legou, pelo carisma

\footnotetext{
${ }^{1}$ Trata-se aqui das seguintes obras: Casa grande \& senzala (Gilberto Freyre, 1933); Raízes do Brasil (S. B. de Holanda, 1936); Formação do Brasil contemporâneo (Caio Prado Jr., 1942) e Economia colonial no Brasil nos séculos XVI e XVII (tese de doutoramento de Celso Furtado, defendida na França em 1948).

${ }^{2}$ Folha da Manhã, 26/05/1948.
} 
pessoal que cronistas da época lhe imputavam, Simonsen vem merecendo vários textos biográficos e relativos à sua obra, desde, pelo menos, 1948, quando os jornais paulistas e cariocas noticiaram seu falecimento. Essa aura, que de alguma forma persistiu ao longo dos anos, torna complexa a análise da historiografia sobre a vida e obra de Simonsen.

Em 1963, é publicado, por Heitor Ferreira Lima, que trabalhara com Simonsen na FIESP, um estudo sobre Roberto Simonsen e o barão de Mauá, que os qualificava como "pioneiros do desenvolvimento" ". Trata-se de uma tentativa de colocar Simonsen na linha daqueles que batalharam pela industrialização, pela superação da condição primário-exportadora do Brasil, resistindo à ideia de vocação agrícola natural. Neste texto e em escritos posteriores, Lima prioriza o aspecto biográfico e comenta, de forma quase laudatória, passagens dos textos de Simonsen, mostrando as qualidades de caráter do autor e seus compromissos com a industrialização brasileira. Ainda que de forma assistemática, Lima associa, por meio de evidências textuais, a figura de Roberto Simonsen a temas recorrentes no pensamento econômico brasileiro, como o protecionismo, o planejamento, o pauperismo e as formas de cálculo da renda nacional.

A partir do trabalho seminal de Lima, outros estudos surgem, dos anos 1970 em diante, que tratam da vida e obra do industrial paulista. Para os propósitos deste trabalho, que se situa num registro de história do pensamento econômico, os estudos que se referem à vida e obra de Roberto Simonsen podem ser divididos em três grupos principais: os que versam sobre Simonsen especificamente ou o têm como um de seus principais temas; as sínteses de história do pensamento econômico que abordam, de alguma maneira, o pensamento simonseniano; e as contribuições recentes que adotam uma linha comparativa.

Entre os trabalhos que se dedicam a Roberto Simonsen, o primeiro a tentar analisar o conjunto da obra de Roberto Simonsen, recorrendo aos seus textos publicados e a alguma literatura referente à personalidade do autor, é a tese de Helena Fanganiello ${ }^{4}$, que faz um abrangente resumo biográfico e esquematiza o pensamento simonseniano em temas diversos, tendo como referencial a questão do desenvolvimento econômico. Do ponto de vista da história do pensamento econômico, o trabalho é importante por apontar Simonsen como precursor brasileiro da teoria do desenvolvimento econômico, mais especificamente da vertente do "desenvolvimento equilibrado". Embora consistente na análise dos textos de Simonsen, a tese de Fanganiello é restrita a tais escritos, não se beneficiando de estudos históricos que permitam colocar o autor em seu contexto, o que torna pouco convincente o argumento de que Simonsen é "precursor" de uma corrente tão específica de pensamento

\footnotetext{
${ }^{3}$ LIMA, Heitor Ferreira. Mauá e Roberto Simonsen: dois pioneiros do desenvolvimento. São Paulo: Edaglit, 1963.

${ }^{4}$ FANGANIELLO, Helena. Roberto Simonsen e o desenvolvimento econômico. São Paulo: FEA/USP, 1970.
} 
como os teóricos do desenvolvimento equilibrado.

Edgard Carone organiza, em 1973, num volume da Coleção Brasiliana (Cia. Editora Nacional), uma coletânea de textos selecionados de Simonsen, que constitui, até hoje, importante referência para o estudo da obra do autor, por ter tornado públicos textos esparsos, cujos originais, em muitos casos, estão restritos a bibliotecas temáticas e arquivos. ${ }^{5}$ Em 1976, Heitor Ferreira Lima publica mais um estudo sobre Simonsen, em larga medida baseado em seu texto de 1963, trazendo informações biográficas pertinentes, mas ainda em tom laudatório e pouco crítico do pensamento simonseniano.

A tese de Vera Cepêda ${ }^{6}$, de 2003, foi uma contribuição importante, cujo argumento central, relacionado à questão política, é que Simonsen teria sido um intelectual à frente de seu tempo e cujas elaborações estavam num horizonte mais progressista que o da média de sua classe: a burguesia industrial. No momento em que radicaliza mais suas posições, propugnando enfaticamente o Estado propulsor do desenvolvimento e atuando nos Conselhos Técnicos, sua liderança se afasta de seus pares. O momento-chave para este afastamento é a participação de Simonsen na Constituinte de 1933-34, em que, segundo a autora, deixa de defender certas convicções intelectuais para subscrever posições da bancada paulista, pelos vínculos políticos que tinha com esta: seria um limite posto pela ideologia industrial da época. Do ponto de vista do pensamento econômico, merece destaque, nesse estudo abrangente, as relações estabelecidas com o pensamento de Friedrich List e o reforço da ideia de que Simonsen é antecipador da teoria do desenvolvimento: no caso de Cepêda, a versão estruturalista cepalina dessa corrente teórica.

Ainda entre os trabalhos que se centram em Roberto Simonsen, cabe menção à tese de Fábio $\mathrm{Maza}^{7}$, que elege como eixo de sua análise a concepção simonseniana de ciência, a qual teria orientado a produção intelectual do autor - tal ideia de ciência é chamada de "idealismo prático". Mais do que a ideia de que há uma concepção de conhecimento científico positivista e darwinista - que estaria a informar o pensamento de Simonsen ao longo dos anos, é digna de nota, neste estudo, a incursão em debates intelectuais da época em que Simonsen atuou, como as questões relativas à raça brasileira, à modernização do país e ao papel do passado colonial em nossa história. Essas incursões, assim como o estudo de ambientes intelectuais, como o da Escola Livre de Sociologia e Política de São Paulo, ajudam

\footnotetext{
${ }^{5}$ SIMONSEN, Roberto. Evolução industrial do Brasil e outros estudos. São Paulo: Cia. Editora Nacional, 1973. (Seleção, notas e bibliografia de Edgard Carone).

${ }^{6}$ CEPÊDA, Vera. Roberto Simonsen e a formação da ideologia industrial no Brasil: limites e impasses. São Paulo: FFLCH/USP, 2003. Tese de Doutorado.

${ }^{7}$ MAZA, Fábio. O idealismo prático de Roberto Simonsen: ciência, tecnologia e indústria na construção da nação. São Paulo: Instituto Roberto Simonsen, 2004.
} 
a situar o autor em seu tempo.

Antes de entrar mais propriamente no próximo grupo de estudos - as sínteses de história do pensamento econômico -, vale mencionar a contribuição pioneira de Nícia Vilela Luz sobre a história do movimento industrialista brasileiro, datada de 1960. Embora trate de poucos textos de Simonsen, a autora destaca que este teria esboçado uma renovação do pensamento industrial brasileiro, no bojo da ofensiva industrialista possibilitada pelas mudanças introduzidas pela crise de 1929 e pela Revolução de 1930. De acordo com Luz, Simonsen procurava reconciliar a indústria com os interesses nacionais, harmonizando capital e trabalho. ${ }^{8}$

Dentro das referidas sínteses de história do pensamento econômico ou industrialista brasileiro, os marcos iniciais poderiam ser a tese de Marisa Saenz Leme ${ }^{9}$, de 1977, e outro estudo de Heitor Ferreira Lima ${ }^{10}$, de 1978. O objeto de estudo de Leme é o pensamento industrial brasileiro, mas seu recorte enfatiza mais a oposição industriais versus lavoura e a atuação da burguesia industrial frente ao operariado, do que o pensamento econômico. Considera Simonsen o principal ator na elaboração de um programa econômico para o Brasil, por parte da burguesia industrial, mas baseia seus argumentos na análise de poucos textos do autor. O livro de Heitor Ferreira Lima é talvez a síntese mais abrangente da história do pensamento econômico no Brasil, abarcando desde os economistas portugueses até as controvérsias estruturalistas e monetaristas em voga nos anos 1970. Embora não aprofunde muito em cada tema, tem no esforço de síntese seu maior mérito. $\mathrm{O}$ capítulo dedicado a Simonsen, embora mencione alguns pontos fundamentais do pensamento do autor, não faz uma análise aprofundada do mesmo.

Em 1988, Ricardo Bielschowsky publica sua tese sobre o pensamento econômico ligado ao ciclo ideológico do desenvolvimentismo, talvez o primeiro entre os trabalhos citados até aqui a enquadrar-se numa perspectiva metodológica de história do pensamento econômico. ${ }^{11}$ Trata-se de obra de fôlego, escorada em ampla pesquisa de textos originais, que compõe um quadro das principais correntes do pensamento econômico brasileiro no período 1930-1964. Simonsen é classificado por Bielschowsky como pioneiro importante das correntes desenvolvimentistas ligadas ao setor privado e ao setor público. O tratamento dado à obra de Simonsen é consistente: o argumento é que seu pensamento se estruturou em torno do protecionismo, num primeiro momento, e do planejamento, posteriormente. Merece reparo,

\footnotetext{
${ }^{8}$ LUZ, Nícia Vilela. A luta pela industrialização do Brasil: 1808-1930. [1960]. 2. ed. São Paulo: Alfa-Ômega, 1975.

${ }^{9}$ LEME, Marisa Saenz. O pensamento industrial no Brasil (1919-1945). São Paulo: FFLCH/USP, 1977.

${ }^{10}$ LIMA, Heitor Ferreira. História do pensamento econômico no Brasil. São Paulo: Cia. Editora Nacional, 1978.

${ }^{11}$ BIELSCHOWSKY, Ricardo. [1988]. Pensamento econômico brasileiro: o ciclo ideológico do desenvolvimentismo. Rio de Janeiro: Contraponto, 2000.
} 
como ficará claro ao longo do trabalho, a ideia de que a obra de Simonsen paira sobre um "vazio téorico"12, assim como o grosso da produção brasileira na área de economia entre os anos 1930 e 1940. O equívoco parece ser motivado pela tendência de mensurar o pensamento de Simonsen - e dos economistas e industrialistas brasileiros anteriores aos anos 1950 - pela régua das formulações teóricas cepalinas.

Carlos Lopes Rodrigues defende, em 2005, dissertação que estuda a controvérsia entre Roberto Simonsen e Eugênio Gudin, na qual se destaca a busca por compreender os referenciais teóricos subjacentes à defesa do protecionismo, feita por Simonsen neste debate: no caso de Simonsen, merecem destaque as relações feitas com Friedrich List e Mihail Manoilescu. ${ }^{13}$ Nesta linha comparativa, vale mencionar o artigo de Flávio Saes, ${ }^{14}$ publicado em 2009, que contrapõe as visões de Celso Furtado e Roberto Simonsen acerca da industrialização e do desenvolvimento econômico. Embora se baseie apenas em alguns textos de Simonsen, o trabalho traz uma contribuição importante ao conectar a perspectiva histórica de Simonsen - interpretação cíclica - com o caráter industrialista de seu pensamento econômico, pouco afeito à economia de base agrária ou colonial. Além disso, o texto aprofunda ideia de que Simonsen foi pioneiro ou precursor da vertente teórica desenvolvimentista cepalina. É também nesta linha comparativa que se iniciou a pesquisa que resultou nesta dissertação: em trabalho de 2011, procurou-se requalificar a participação de Roberto Simonsen no debate com Eugênio Gudin, a partir de suas sintonias internacionais. ${ }^{15}$

Pretende-se que esta dissertação seja uma contribuição à historiografia do pensamento de Roberto Simonsen, avançando em dois sentidos principais: metodologia e fontes. A perspectiva metodológica adotada, no âmbito da história do pensamento econômico, pode ser denominada de reconstrução histórica, com ênfase na difusão internacional do pensamento econômico. Como ficará claro, essa perspectiva exige que a pesquisa abarque um tipo de fonte pouco explorado pelos trabalhos até aqui, qual seja, os autores internacionais referidos, direta ou indiretamente, por Simonsen em seus trabalhos.

Uma referência fundamental para se refletir sobre o fazer do historiador do pensamento

\footnotetext{
${ }^{12}$ BIELSCHOWSKY, 2000, p. 82.

${ }^{13}$ RODRIGUES, Carlos Henrique Lopes. A questão do protecionismo no debate entre Roberto Simonsen e Eugenio Gudin. Campinas: Unicamp, 2005.

${ }^{14}$ SAES, Flávio Azevedo Marques de. "Industrialização e desenvolvimento na perspectiva de duas gerações de pensadores brasileiros: Roberto Simonsen e Celso Furtado". IN: COELHO, Francisco da Silva e GRANZIERA, Rui Guilherme. Celso Furtado e a formação econômica do Brasil: Edição Comemorativa dos 50 Anos de Publicação (1959-2009). São Paulo: Atlas, 2009.

${ }^{15}$ BRUZZI CURI, Luiz Felipe e CUNHA, Alexandre Mendes. "Redimensionando a contribuição de Roberto Simonsen à controvérsia do planejamento (1944-45): pioneirismo e sintonia". IN: Anais do $39^{\circ}$ Encontro Nacional de Economia. ANPEC: Foz do Iguaçu, 2011.
} 
econômico e seus objetos de estudo permanece sendo Schumpeter. ${ }^{16}$ Este autor define três categorias básicas: história da análise econômica, história dos sistemas de economia política e história do pensamento econômico. A história da análise econômica, que é o projeto de Schumpeter em seu livro clássico, seria a história da teoria econômica em si, dos conceitos e instrumentos científicos (do ponto de vista da ciência empírica) usados pelos economistas para compreender a realidade. É uma categoria não muito clara, que se define por oposição às outras. Os sistemas de economia política seriam "o amplo conjunto de políticas econômicas que seu autor sustenta tendo por fundamento determinados princípios unificadores”"17. Já o pensamento econômico seria a "soma total de todas as opiniões e desejos referentes a assuntos econômicos, especialmente relativos à política governamental que, em determinados tempos e lugares, pertencem ao espírito público" ${ }^{" 18}$. A história da análise econômica seria, portanto, aquilo que "sobra", ao se retirar a história da política econômica e as opiniões e desejos que acompanham o evolver da economia ao longo do tempo - em suma, haveria que se separar os "humores do tempo" da análise econômica pura. Embora pretenda fazer uma história da análise econômica, Schumpeter logra construir uma obra que extrapola esses limites estreitos colocados no projeto inicial, talvez porque essa separação total não seja muito possível, ao se produzir uma narrativa histórica do pensamento econômico.

Num momento posterior, Mark Blaug propõe duas novas categorias, emprestadas à filosofia, relacionadas em alguma medida com aquilo que Schumpeter já havia discutido. Para Blaug, haveria duas formas básicas de se fazer história do pensamento econômico: abordagem absolutista ou reconstrução racional e abordagem relativista ou reconstrução histórica. As categorias schumpeterianas "história do pensamento econômico" e "história dos sistemas de economia política" se fundem na abordagem relativista.

O relativista considera todas as teorias formuladas no passado como um reflexo mais
ou menos fiel das condições contemporâneas, de modo que cada teoria se justifica
em princípio igualmente em seu próprio contexto; o absolutista só tem olhos para o
desenvolvimento estritamente intelectual do tema, considerado como uma
progressão incessante do erro até a verdade.

Essas categorias - absolutismo e relativismo - podem ser desdobradas em outras. Screpanti e Zamangni veem dois tipos de abordagem, dentro do âmbito mais geral das formas absolutistas de se entender a história do pensamento econômico. ${ }^{20} \mathrm{~A}$ primeira seria a visão “incrementalista", adotada por economistas neoclássicos como Knight, Stigler e o próprio

\footnotetext{
${ }^{16}$ SCHUMPETER, Joseph Alois. História da análise econômica. v.1. [1954] Rio de Janeiro: Fundo de Cultura, 1964.

${ }_{17}$ SCHUMPETER, 1964. p. 64.

${ }^{18}$ SCHUMPETER, 1964, pp. 64-65.

${ }_{19}^{19}$ BLAUG, Mark. Teoría económica en retropección. [1962]. México, D.F.: Fondo de Cultura Económica, 2001. pp. 17-18.

${ }^{20}$ SCREPANTI, Ernesto e ZAMAGNI, Stefano. An outline of the history of economic thought. 2. ed. Oxford: Oxford University Press, 2005. pp. 1-15.
} 
Blaug, em seu manual Economic theory in retrospect. Nessa perspectiva, a ciência econômica progride pouco a pouco, sendo que cada teoria beneficia-se da anterior, num processo de acúmulo de saber similar a uma bola de neve que, ao rolar, torna-se mais robusta à medida que junta o que encontra pela frente. Não há espaço para as crises, para as mudanças de orientação, trata-se de uma história das verdades econômicas. A segunda perspectiva seria a "catastrofista", representada pela aplicação do modelo de revoluções científicas de Kuhn à ciência econômica: o conhecimento, neste caso, evolui por meio de revoluções, ocasionadas pelo acúmulo de anomalias no paradigma dominante. À diferença da visão "incrementalista", a kuhniana vê a ciência como progredindo de forma descontínua, mas ambas se situam no âmbito absolutista, isto é, atentam para aquilo que Schumpeter chamou de análise econômica, sem preocupar-se com os fatores sociais ou culturais que afetam a produção de ideias econômicas.

Do ponto de vista relativista, haveria diversas formas de produzir história do pensamento econômico, de acordo com o tipo de fator histórico que se privilegia como influência mais forte sobre a produção de ideias econômicas. Eric Roll, por exemplo, baseia sua abordagem na "convicção de que a estrutura econômica de cada época e as mudanças que sofre são as principais influências atuantes sobre o pensamento econômico". ${ }^{21}$ A economia smithiana representaria, nessa perspectiva, a situação em que a ordem capitalista estava em condições de equilíbrio, sendo este equilíbrio baseado na pequena fábrica não-mecanizada e numa economia de troca desenvolvida no âmbito de um mercado nacional, no qual a mão invisível era capaz de integrar produção agrícola e industrial. Já o sistema walrasiano representava uma ordem econômica em que a competição era quase perfeita, nos mercados de bens e de trabalho, ao menos nos países mais industrializados. ${ }^{22}$ Outros fatores podem ser eleitos como determinantes da produção das ideias econômicas: o político, o geracional e mesmo o cultural. A visão relativista tende a ser adotada por acadêmicos de orientação marxista e por historiadores de forma geral, que não adotam uma orientação positivista. Roll, Mitchell, Stark e os próprios Screpanti e Zamagni podem ser citados como seguidores desta perspectiva de estudo.

No fundo, esta é a tensão que divide os estudos de história do pensamento econômico: ora pendem para a reconstrução do núcleo teórico ou científico do pensamento dos economistas, vendo a ciência econômica como algo que progride analiticamente, ora se inclinam à reconstituição histórica da formação das ideias. De um lado, parte-se do pressuposto de que é possível isolar os aspectos ideológicos e políticos da análise econômica

\footnotetext{
${ }^{21}$ ROLL, Eric. Historia de las doctrinas económicas. México, D.F.: Fondo de Cultura Económica, 1971. p. 14.

${ }^{22}$ SCREPANTI e ZAMAGNI, 2005, p. 7.
} 
pura; do outro, as ideias econômicas são parte integrante de um quadro ideológico e político. Ainda que ambas as abordagens contribuam para a construção do conhecimento em história do pensamento econômico, a ênfase, neste trabalho, tende a ser uma dessas duas linhagens de pesquisa: a reconstrução histórica, em virtude da forma como se enxerga o objeto de estudo.

Roberto Simonsen foi um intelectual político, que não só escreveu tratados de economia e de história, mas que se dedicou, sobretudo, à defesa de um projeto de classe. Foi um personagem importante no processo de consolidação da hegemonia da burguesia industrial no Brasil. Nos termos de Gramsci, poder-se-ia qualificar Simonsen como um intelectual orgânico da burguesia industrial. A categoria de intelectual tem aqui um sentido que não se prende exatamente à pessoa, mas à sua função: ser intelectual é exercer uma função organizativa no processo de construção de hegemonia. Para ser mais preciso, o momento crítico do estabelecimento da hegemonia de uma classe sobre as demais é quando seus interesses específicos se tornam os interesses da sociedade como um todo e passam a orientar o governo. Ora, como ficará claro ao longo da dissertação, um dos eixos da atuação de Simonsen, como economista e como historiador, é associar a ideia de progresso nacional com o desenvolvimento industrial. A viabilidade do Brasil, como nação, passaria, para Simonsen, pela sua transformação em país industrializado, pelo "deslocamento do eixo dinâmico" da economia para a indústria. A defesa de interpretações da ciência econômica e da história, que enfatizam a industrialização e elevam-na ao posto de interesse nacional ou de necessidade histórica inelutável, não acontece apenas em livros ou tratados: dá-se na Assembleia Constituinte, na Câmara e no âmbito do próprio Executivo federal. Portanto, trata-se de uma produção intelectual eivada de um elemento ideológico que não pode ser separado dela, como quer Schumpeter, porque é constitutivo da mesma. ${ }^{23}$

A opção pela reconstituição histórica, apoiada no reconhecimento da função organizativa de Simonsen como intelectual orgânico de uma classe, não deve obscurecer as especificidades de seu pensamento, aquilo que o torna mais do que um apologista dos interesses da burguesia industrial. Essas especificidades podem ser resumidas em duas: interpretação histórica e sintonias internacionais. Roberto Simonsen granjeou um lugar no cânone do pensamento social brasileiro com sua contribuição historiográfica, a História econômica do Brasil, de 1937, que é uma obra de síntese, contendo uma interpretação da história econômica do Brasil seguida e combatida por gerações de historiadores: é a ideia dos ciclos, tomada de empréstimo a João Lúcio de Azevedo, aplicada à evolução da economia brasileira. Outros industrialistas

\footnotetext{
${ }^{23}$ Sobre o conceito de intelectual orgânico em Gramsci e sua relação com o processo de construção de hegemonia, ver GRAMSCI, Antonio. Cuadernos de la cárcel. Tomo II. Caderno 4. 2. ed. México, D.F.: Ediciones Era, 1999. pp. 168-170 e p. 188.
} 
contemporâneos de Simonsen, como Paulo Assumpção e Vicente Galliez, embora defendessem a indústria com argumentos contundentes, não chegaram a elaborar uma interpretação da história do Brasil, calcada em pesquisa e análise de dados, que enfatizasse o caráter efêmero da riqueza gerada nos processos cíclicos da economia colonial.

A outra especificidade importante refere-se às influências teóricas. Simonsen foi um autor que se utilizou de amplo leque de referências estrangeiras para conferir legitimidade e dar suporte às suas elaborações. Para além da influência já estudada de Friedrich List e Mihail Manoilescu, há autores ligados a uma matriz alemã, como Rodbertus e Wagner, e mesmo autores russos, como Prokopovitch e Woytinsky, com os quais Simonsen estava em sintonia. A ideia de sintonia, mais do que influência, serve para caracterizar essa situação estudada aqui: Simonsen não aderia exatamente a uma escola de pensamento, nem utilizava esses autores de forma sistemática, em todos os seus trabalhos. Citava-os, tomava-lhes ideias que fossem construtivas para cada argumentação, para legitimar cada texto perante seu respectivo público-alvo. Mas certamente estava em contato com seus escritos, buscava neles elementos para formular seu próprio pensamento. Em sintonia com esses pensadores, Simonsen estava inserido num ambiente de ideias econômicas, marcado sobretudo pela preocupação com a evolução econômica de nações atrasadas ou atingidas pela guerra, pelo protecionismo industrial e pelas propostas de planejamento.

É em virtude dessa especificidade do pensamento simonseniano que esta dissertação comporta uma dimensão de difusão internacional das ideias econômicas. ${ }^{24}$ José Luís Cardoso elenca três atributos principais que justificam o estudo da difusão internacional das ideias. O primeiro seria o aprofundamento da compreensão dos autores apropriados internacionalmente: as leituras seletivas em países estrangeiros, os objetivos com os quais determinado autor é referido, a utilização de recomendações e receituários no campo da política econômica - tudo isso alarga o conhecimento sobre o autor apropriado. Em segundo lugar, o estudo da difusão de ideias permite rever ou esclarecer melhor a relação entre precursores e antecipadores, relativizando auras de pioneiros ou inventores e permitindo que se identifiquem ambientes favoráveis a que certas ideias vicejem. O terceiro atributo é relacionado à possibilidade de melhor aquilatar a importância e impacto de escolas heterodoxas no país receptor, relativizando esquemas, por vezes muito rígidos, de arrumação e classificação de autores. Todos esses atributos da abordagem de difusão das ideias podem ser entendidos como meios de se construir uma história nacional do pensamento econômico.

\footnotetext{
${ }^{24}$ CARDOSO, José Luís. "Reflexões periféricas sobre a difusão internacional do pensamento econômico". Nova Economia, vol. 19, $\mathrm{n}^{\circ}$ 2. Belo Horizonte, 2009.
} 
A difusão internacional do pensamento econômico constitui um poderoso instrumento que visa tanto melhor compreensão do processo de formação da ciência econômica quanto uma tomada de consciência das suas implicações sobre o funcionamento e a mudança da realidade econômica e social num contexto nacional determinado. ${ }^{25}$

Em seu estudo comparativo sobre as teorias do subdesenvolvimento na Romênia e no Brasil, Joseph Love afirma que, ao se fazer esse tipo de abordagem que capta a difusão internacional, o menos importante é o vínculo direto entre as ideias de um país e de outro. Há, segundo Love, três processos dignos de interesse nesse tipo de estudo: o empréstimo de ideias originárias de outras partes, a adaptação ou transformação dessas ideias e a criação ou recriação independente de proposições surgidas em outras épocas e outros lugares. Não raro, discute-se se é correto dizer que determinada ideia foi, de fato, tomada de "empréstimo", negligenciando-se o processo de recriação e redescoberta de uma ideia em outro contexto. ${ }^{26}$

Essa dimensão da pesquisa, que incorpora a difusão internacional de ideias, pressupõe que se compulsem fontes pouco trabalhadas nos estudos referidos, que versam sobre Roberto Simonsen em particular. Trata-se dos livros e escritos de época, que foram objeto da leitura de Simonsen e que circularam no meio intelectual de seu tempo. Chega-se a esses textos ora por meio de citações textuais, em muitos casos somente o nome de algum autor, ora por meio da afinidade de ideias e conteúdos. Na verdade, uma combinação desses dois tipos de indícios produz resultados interessantes: ao identificar um autor citado num discurso, por exemplo, que serve a embasar determinada argumentação, busca-se, entre as obras do autor que circularam no Brasil no momento da referência, elementos do conteúdo trabalhado por Simonsen em seu texto, permitindo que se demonstre a sintonia entre autores. A circulação de uma obra estrangeira em determinado contexto nacional pode ser investigada a partir de indícios como: sua presença ainda hoje em certas bibliotecas ou arquivos, data de edição, editora e língua na qual foi traduzida.

Para além do quesito específico da difusão internacional, a proposta de reconstrução histórica do pensamento se associa ao uso de fontes que ajudem a entender o contexto intelectual e institucional em que atuou Roberto Simonsen. Um exemplo deste tipo de fonte são os programas da Escola Livre de Sociologia e Política de São Paulo (ELSP), onde Simonsen ministrou o curso que deu origem a seu livro clássico. A partir desses programas e da história da instituição em que o curso foi dado pode-se aprofundar a compreensão de como se deu a elaboração da interpretação simonseniana da história do Brasil. A ELSP era vinculada a um projeto, pós-1932, de criação de quadros qualificados no âmbito da elite

\footnotetext{
${ }^{25}$ CARDOSO, 2009, p. 263.

${ }^{26}$ LOVE, Joseph. A construção do Terceiro Mundo: teorias do subdesenvolvimento na Romênia e no Brasil. Rio de Janeiro: Paze Terra, 1998.
} 
paulista, com claro viés técnico-prático, em resposta intelectual ao projeto de fundação da USP, mais voltado para a especulação acadêmica. Esse ambiente intelectual não somente condicionou a elaboração das ideias de Simonsen, mas foi determinante fundamental nesse processo.

O historiador que se ocupa do pensamento de Roberto Simonsen se defronta com a dificuldade associada à inexistência de um arquivo pessoal deste pensador. A Coleção Roberto Simonsen, hoje pertencente à Biblioteca do IFCH/Unicamp, inclui livros, antes pertencentes ao acervo da FIESP, das décadas de 1920, 1930 e 1940, que teriam sido da biblioteca de Simonsen. Para além da Coleção Roberto Simonsen, consultamos os arquivos da Escola Politécnica da USP e da Escola de Sociologia e Política, instituições pelas quais Simonsen passou. Para a reconstrução de alguns episódios biográficos de Simonsen, recorreuse a jornais paulistas de circulação à época, como a Folha da Manhã.

\section{Estrutura da dissertação}

Dentro da proposta de investigar o pensamento econômico de Roberto Simonsen, numa perspectiva de reconstrução histórica do pensamento, que inclui a dimensão da difusão internacional das ideias, esta dissertação se divide em três capítulos, além desta Introdução.

O primeiro capítulo é dedicado à reconstrução da trajetória de Roberto Simonsen, em seu contexto histórico. Norteia o capítulo a ideia de que a atuação de Simonsen, como empresário e intelectual, reflete os projetos de país vigentes nos períodos em que atravessou. Até o final dos anos 1920, na Primeira República, Simonsen se destacou como dono de uma construtora que realizou obras marcantes, ligadas a um projeto de modernização do Brasil, que ainda não incluía de fato a industrialização integrada. Com a formação do Centro das Indústrias do Estado de São Paulo (1928) e a ascensão de Vargas em 1930, há uma inflexão importante: Simonsen torna-se porta-voz de uma classe, mas seu alcance político se restringe à esfera parlamentar e das associações classistas. Destacam-se as mudanças ocorridas com o Estado Novo, quando o planejamento estatal passa a fazer parte da agenda do governo e uma nova forma de representação - os conselhos técnicos - dá viabilidade à representatividade industrial no âmbito do Executivo. É neste contexto que Simonsen é chamado a posicionar-se sobre o planejamento econômico, em discussão com o principal economista liberal brasileiro à época, Eugênio Gudin.

O segundo capítulo é centrado em reconstruir a formação do nacionalismo de Simonsen, baseando-se em seus textos, em textos de autores estrangeiros referidos por Simonsen e nas fontes disponíveis em instituições acadêmicas pelas quais passou, como aluno e professor. Se 
estava praticamente ausente dos textos da década de 1910, a perspectiva nacionalista/industrialista começa a aparecer ao longo da década de 1920, para amadurecer na formulação de uma interpretação da história do Brasil calcada neste nacionalismo específico, que associa progresso nacional com desenvolvimento industrial. Faz-se análise detida do livro História econômica do Brasil e de outras contribuições historiográficas de Simonsen.

O terceiro capítulo versa sobre os dois principais aspectos do pensamento econômico de Roberto Simonsen: o protecionismo e o planejamento. O eixo de análise é dado pelas sintonias que se pode estabelecer entre Simonsen e os autores que referencia em seus textos. No caso do protecionismo, são destacados dois momentos-chave para o estudo da difusão internacional de ideias: a conferência de 1931, no Mackenzie College de São Paulo e a participação no debate acerca do Tratado Comercial Brasil-Estados Unidos, de 1935. O estudo sobre o planejamento se centra na controvérsia Simonsen-Gudin (1944-45), terminando-se o capítulo com as questões relativas ao pós-Segunda Guerra e à América Latina. Por fim, delineiam-se as conclusões. 


\section{Capítulo 1. Roberto Simonsen: da modernização ao pensamento nacional}

Nascido em 1889, Roberto Simonsen atuou, como empresário e pensador, do início do século XX a 1948, data do seu falecimento. Houve, ao longo deste período, mudanças importantes na economia e na sociedade brasileiras, que condicionaram as formas de participação de Simonsen como intelectual e industrial. Em suma, pode-se dizer que este período foi marcado pela aceleração do processo de industrialização do Brasil. Essa transição não significou apenas a instalação de atividades de transformação até então pouco expressivas no país, mas envolveu transformações sociais e econômicas, condicionadas pela posição periférica ocupada pelo Brasil no capitalismo mundial.

A produção de gêneros primários para a exportação continuava desempenhando papel fundamental na economia brasileira, mas seu dinamismo já não era dado exclusivamente pelas atividades primário-exportadoras. Essa transição para uma economia industrializada esteve associada, na República Velha, ao processo de modernização da forma como o define Celso Furtado $^{27}$, associado à imitação de padrões de consumo estrangeiros, ao crescimento das cidades e à concentração econômica no Centro-Sul do país. O crescimento e a diversificação dos estabelecimentos industriais estiveram ligados à ampliação do fornecimento de insumos fundamentais à atividade fabril: os setores de eletricidade, combustíveis, ferro e aço foram dinamizados, ainda que muitas vezes de forma insuficiente, dado o caráter limitado do processo de modernização em curso. Já relevante para o escoamento da produção exportada, a rede de transportes passou a ter a importância de articular o nascente mercado interno para produtos industriais, polarizado por São Paulo e pelo Distrito Federal. A sociedade urbana em formação também trouxe consigo novas possibilidades sociopolíticas, com a formação de uma classe industrial organizada, de um operariado industrial e de grupos médios urbanos com interesses próprios.

Durante o período em que Simonsen viveu, portanto, houve importantes alterações na paisagem econômica e social brasileira. Atuou durante a Primeira República e a Era Vargas, vindo a falecer no início do governo Dutra, primeiro da série de governos democraticamente eleitos que se sucederam até o golpe militar de 1964. As condições para a atuação de Simonsen e para o seu alcance como participante ativo desse processo de transformação que ocorreu no Brasil foram distintas ao longo de sua vida. O estudo dos textos de Simonsen

\footnotetext{
27 O conceito de modernização refere-se, para Furtado, a "este processo de adoção de novos padrões de consumo, correspondente a níveis mais elevados de renda, na ausência de desenvolvimento econômico". "Desenvolvimento econômico" é entendido como acumulação de capital e adoção de processos produtivos mais eficientes. A modernização seria, portanto, a sofisticação dos padrões de consumo motivada por um aumento da renda baseado na extração de recursos naturais não renováveis e/ou na realocação de recursos, visando à especialização, no âmbito da divisão internacional do trabalho. Ver FURTADO, Celso. O mito do desenvolvimento. Rio de Janeiro: Paz e Terra, 1974.
} 
revela que suas preocupações até meados da década de 1920 eram quase integralmente voltadas para a melhoria das condições de funcionamento de suas empresas, sobretudo da principal delas, nesses anos iniciais, a Companhia Construtora de Santos, voltada para a execução de projetos de modernização urbana. Isso mudaria a partir dos anos 1920, quando Simonsen começava a tratar de questões associadas ao projeto de classe dos industriais, que estavam empenhados em construir a sua hegemonia nacional. Os problemas nacionais, notadamente aqueles relacionados à indústria brasileira e ao atraso do Brasil com relação à das nações ricas, passaram ao primeiro plano para Simonsen. Essa perspectiva nacionalista e industrialista norteou a interpretação de Simonsen da história do Brasil e o seu tipo de abordagem dos problemas econômicos brasileiros.

Roberto Simonsen, todavia, restringia sua atuação política, na Primeira República e durante boa parte dos anos Vargas, à condição de empresário e de líder de associações industriais como o Centro das Indústrias do Estado de São Paulo/CIESP (depois Federação das Indústrias do Estado de São Paulo/FIESP) e o Centro Industrial do Brasil (CIB) que, mais tarde, deu origem à Confederação Nacional da Indústria (CNI): não havia, até o Estado Novo, uma participação direta no âmbito do aparelho planejador estatal, exceção feita à participação nos órgãos de coordenação da "guerra paulista" de 1932. Simonsen foi deputado classista, representando as entidades empresariais, na Constituinte de 1933 e na legislatura que se iniciou em 1935. Porém, foi durante o Estado Novo que integrou o Conselho Federal de Comércio Exterior e o Conselho Nacional de Política Industrial e Comercial, onde pôde formular propostas de planejamento industrial que de fato foram debatidas como possíveis vias de desenvolvimento para o Brasil. Essa mudança - de empresário executor de melhorias urbanas, preocupado em otimizar tempos e tarefas a formulador de propostas de política econômica nacional, que discutia com o já renomado economista Eugênio Gudin - esteve associada a uma série de fatores, entre os quais certamente merecem destaque as transformações econômicas e políticas vividas pelo Brasil. Foram essas transformações, refletidas no aparelho do Estado, que abriram a possibilidade de um tipo de representação para os industriais no âmbito do poder Executivo, por meio dos Conselhos Técnicos. Por meio desse tipo de participação mais direta na definição dos rumos da política econômica do país, partir de 1937 e sobretudo no episódio da controvérsia do planejamento (1944-45), Simonsen pôde exercer influência significativa sobre o debate de ideias econômicas em âmbito nacional.

Com a Revolução de 30 e o Estado getulista, houve uma importante diversificação do aparelho estatal, no sentido de fomentar a produção industrial e incentivar setores específicos da economia. Com a Grande Depressão, o liberalismo econômico e político em franco 
declínio e o advento do exitoso primeiro Plano Quinquenal soviético (1928-1933), o planejamento aparecia como estratégia importante para as administrações públicas de países capitalistas. No Brasil, o governo de Vargas foi ambíguo em muitos aspectos - e as medidas imediatamente posteriores a 1930 não denotam um claro alinhamento do governo com a planificação e com o desenvolvimento econômico pela via da industrialização. No Estado Novo, porém, a inclinação se tornou mais clara e o projeto nacional de industrialização planejada passou a orientar, de forma mais marcada, a atuação do Estado.

As duas próximas seções discutem os dois períodos históricos nos quais atuou Roberto Simonsen: a Primeira República e a Era Vargas, com ênfase nas questões econômicas e no tipo de Estado vigente, nesses dois momentos. O objetivo é fornecer elementos para uma reconstrução histórica das ideias de Simonsen, na perspectiva mencionada na Introdução. A seção 1.1. trata da Primeira República, com base em algumas interpretações do período, enfatizando a ideia de um projeto vigente de modernização do Brasil. A seção 1.2. trata da Era Vargas, destacando as ambiguidades do governo e as alterações ocorridas com o Estado Novo, que permitiu aos industriais um novo tipo de representação política.

\subsection{Primeira República e modernização}

O período da chamada Primeira República ou República Velha se inicia com a queda do poder monárquico no Brasil e as consequências da desestruturação da estrutura imperial: não havia mais a figura do imperador, asseguradora da unidade nacional, no nível simbólico, e nem o Poder Moderador, em torno do qual se organizava a política brasileira. Os estados da federação, apoiados pelos potentados locais, os coronéis, apareciam como unidades de poder mais relevantes do que haviam sido durante a Monarquia: podiam organizar suas próprias milícias e tomar empréstimos externos. São Paulo e Minas Gerais se destacavam como atores principais no processo político, mas o Rio Grande do Sul desempenharia um papel relevante, sobretudo depois de apaziguadas as tensões da primeira década republicana, que, no estado, tomaram a forma de uma guerra civil. Após os conflitos dos anos 1890, cujos exemplos mais marcantes foram a Revolução Federalista no Extremo Sul e as batalhas de Canudos, no Nordeste, vigorou uma relativa estabilidade política, sob a predominância da política dos governadores, que garantia a permanência no poder das elites ou oligarquias dirigentes. Do ponto de vista econômico, a Primeira República foi o período de auge do café e do complexo cafeeiro paulista, onde se instalaram, gradativamente, relações capitalistas de produção. A indústria dava seus primeiros passos, com destaque para os ramos leves: têxteis e alimentos, mas alguma diversificação foi atingida nos anos 1920. 
As articulações entre os fatos elencados acima foram interpretadas de maneiras distintas pela historiografia: interessa aqui indagar, a partir de alguns autores que interpretaram a Primeira República, o caráter do projeto político e econômico vigente no Brasil neste período. Isso permitirá situar a produção dos primeiros anos de atuação intelectual de Roberto Simonsen numa perspectiva histórica. Grosso modo, podem-se dividir as interpretações da República Velha em duas correntes principais: a dos que enfatizam a hegemonia da economia cafeeira e sua contrapartida política - a predominância do poder estadual, sob a liderança de São Paulo e Minas - e os que procuram rever estas teses, qualificando e reavaliando a importância dos interesses cafeeiros e a ideia de uma fragmentação política que gera conflitos de caráter exclusivamente inter-regional

À primeira linhagem pertencem, entre outros, os trabalhos de Maria do Carmo Campello Souza e Joseph Love. Para Souza ${ }^{28}$, o Brasil monárquico era um país ligado internamente pelo mercado nacional de escravos (e pelo poder imperial): quando esta estrutura se desfez, o país se tornou um conjunto de seções justapostas, vinculadas ao mercado internacional. Dentre essas regiões produtoras, a cafeeira se destacava como polo dinâmico, sendo, então, o movimento republicano, ao lutar pela autonomia regional e pela ligação com o mercado mundial sem as injunções da União, expressão do setor cafeicultor. Nesse sentido, não haveria um projeto autônomo do "setor interno" da economia brasileira: "Ligado umbilicalmente à lavoura cafeeira, crescendo à sombra de sua política econômico-financeira, o setor interno não apresentava qualquer oposição fundamental à estrutura vigente que levasse seus representantes a tentativas de superá-las."29

O foco de poder do sistema político da Primeira República se localizava nos Estados, sob hegemonia dos mais fortes: era um sistema liberal na sua forma e oligárquico quanto ao funcionamento efetivo. País periférico e dependente das exportações de insumos básicos, ao Brasil foram se impondo os princípios liberais do laissez faire, que eram um amparo ideológico e institucional das nações mais poderosas, garantindo a desigualdade do sistema: aos países periféricos, cabia exportar gêneros primários. No caso brasileiro, à adoção dos princípios liberais em nível externo, juntou-se a prática de dirigismo interno, isto é, a política de valorização do café, possibilitada pela condição de quase monopólio do fornecimento internacional da rubiácea. Na visão da autora, não se constituiu, na Primeira República, uma ideologia industrialista capaz de projetar-se significativamente no nível político. "No período assinalado, os interesses urbano-industriais se beneficiavam do quadro montado para atender

\footnotetext{
${ }^{28}$ SOUZA, Maria do Carmo Campello. "O processo político partidário na Primeira República”. IN: MOTA, Carlos Guilherme (org.). Brasil em perspectiva. São Paulo: Alfa-Ômega, 1976.

${ }^{29}$ SOUZA, 1976, p. 165.
} 
as reivindicações da atividade exportadora" ${ }^{30}$. Numa visão concorde com Celso Furtado ${ }^{31}$, Campello de Souza entende que o mercado interno beneficiava-se, indiretamente, da política de defesa do café de duas formas: a manutenção da renda agrícola sustentava o crescimento do mercado e a política de desvalorização cambial protegia a indústria nascente. O período da Primeira República seria marcado, em suma, pela descentralização política - o foco de poder estava nos estados - e pela hegemonia dos interesses econômicos cafeeiros, o que se refletia numa preponderância das oligarquias estaduais ligadas ao café, sobretudo de São Paulo. A política dos governadores dava sustentação a esse sistema, ao arbitrar os potenciais conflitos entre as oligarquias dominantes, Minas e São Paulo, garantindo seu domínio sobre as oligarquias dissidentes.

Joseph Love está na mesma linha de Campello de Souza ao dirigir seus dois livros sobre o período justamente para o estudo do papel de duas unidades da federação: o Rio Grande do Sul e São Paulo ${ }^{32}$. Em seu estudo sobre São Paulo, Love enfoca a elite paulista, cujos interesses estão ligados, direta ou indiretamente, à economia cafeeira. Ainda que complexa, essa elite é vista como um todo articulado, capaz de uma ação coesa em questões políticas: o elemento que dava coesão a sua atuação era a cafeicultura. O PRP, partido que dominou boa parte da política estadual no período, é tido como um partido da cafeicultura ou um partido “dos fazendeiros". Embora influente, a elite paulista não teria logrado se sobrepor, a todo momento, aos interesses econômicos do governo federal: este tinha interesses próprios, associados a suas receitas (dependentes do imposto de importação) e à credibilidade externa do Brasil, fundamental para as contas do governo. Momentos de preocupação com a moeda estável e o crédito externo, como houve nos governos de Campos Sales, Artur Bernardes e Washington Luís, são vistos por Love como uma manifestação desses interesses do poder central, que se chocavam com os interesses de um grupo relativamente coeso, qual seja, a elite paulista.

Embora já houvesse industriais no âmbito dessa elite paulista estudada por Joseph Love, o autor é enfático ao reconhecer que predominavam os interesses ligados à economia exportadora, como demonstra o espírito associativo dos cafeicultores, muito maior do que o

\footnotetext{
${ }^{30}$ SOUZA, 1976, p. 220.

${ }^{31}$ Trata-se de duas teses clássicas de Furtado, presentes em Formação econômica do Brasil. A primeira, baseada nos trabalhos de Prebisch, refere-se à tendência secular à deterioração dos termos de troca dos produtos primários, que era contrarrestada pela desvalorização cambial, atendendo aos interesses dos produtores do café, principal produto de exportação brasileiro. A segunda é que os benefícios gerados pela política de proteção ao café (manutenção dos preços - e por conseguinte da renda interna elevados e desvalorização cambial) beneficiavam o mercado interno, mas indiretamente, ou inconscientemente. Essa ideia será discutida mais adiante.

${ }^{32}$ Neste trabalho, o foco é no estudo sobre São Paulo: LOVE, Joseph. A locomotiva: São Paulo e a federação brasileira (18891937). Rio de Janeiro: Paz e Terra, 1982. Sobre o Rio Grande do Sul, ver LOVE, Joseph. O regionalismo gaúcho e as origens da Revolução de 30. São Paulo: Perspectiva, 1975.
} 
dos industriais. A Sociedade Paulista de Agricultura (sucessora do pouco expressivo Centro da Lavoura Paulista, criado nos anos 1890) foi fundada em 1902, ano de grande safra, preços baixos e taxa cambial elevada. A SPA patrocinou o programa da primeira valorização do café, em 1906-08, e seus membros ocuparam cargos de secretários e ministros da agricultura. Outras associações ligadas ao setor agrícola foram fundadas posteriormente com o fito de combater a influência da SPA. Destacava-se a Sociedade Rural Brasileira, organizada em 1919. As associações se aproximaram na defesa da terceira operação valorizadora, em 192123, mas dissensões voltaram a existir por ocasião da crise de 1929.

De toda forma, os industriais tiveram muito menos influência do que as associações agrícolas, na leitura de Love. Ainda que os industriais têxteis de São Paulo tivessem fundado o Centro das Indústrias de Fiação e Tecelagem de São Paulo (CIFT-SP), em 1919, a categoria só teve algum peso político a partir de 1928, quando romperam com a Associação Comercial de São Paulo, fundando o Centro das Indústrias do Estado de São Paulo (CIESP). Mesmo ao longo dos anos 1930, sob a presidência de Vargas, não teria havido, para Joseph Love, uma política consistente de proteção e a apoio à indústria em geral. ${ }^{33}$ No âmbito dessa elite paulista, havia elementos de nacionalismo, mas seu projeto era fundamentalmente vinculado à economia cafeeira e aos interesses estaduais.

Na esfera ideológica, os intelectuais paulistas, que constituíam importante segmento
da burguesia nacional, desenvolviam as bases de um nacionalismo autêntico,
superando definitivamente a xenofobia do nativismo. Entretanto, é bastante
plausível que, pelo menos até a década de 1930 , o poder crescente do governo
estadual tenha contribuído para os paulistas conceberem o sistema político nacional
como idêntico a São Paulo. ${ }^{34}$

Na linha revisionista, Winston Fritsch e Gustavo Franco qualificam, em estudo sobre o padrão-ouro no Brasil da Primeira República, a ideia de uma prevalência dos interesses cafeeiros, à qual estaria associada a desvalorização cambial. ${ }^{35} \mathrm{Um}$ dado importante apresentado neste trabalho é que, embora fosse uma economia dependente do setor exportador, o Brasil não era uma grande economia aberta, na comparação com outros agroexportadores. $\mathrm{O}$ valor das exportações per capita do Brasil teria subido levemente de 1872 a 1913, de 11,7 para 12,9 dólares, devido ao boom da borracha. Mas ainda era baixo na comparação com o Uruguai (US\$ 19,7); Chile (US\$ 41,4) e Argentina (US\$ 66,9). ${ }^{36}$ Partindo dessa ideia de que não era somente o interesse do setor exportador de café que dava a tônica da política econômica brasileira do período, o modelo de Fritsch e Franco procura analisar os

\footnotetext{
${ }^{33}$ LOVE, 1982, pp. 182-183.

${ }^{34}$ LOVE, 1982, p. 194.

35 FRITSCH, Winston e FRANCO, Gustavo. "Aspects of the Brazilian experience under the gold standard". Texto para discussão n’ 286. Rio de Janeiro: Departamento de Economia/PUC-Rio, 1992.

${ }^{36}$ FRITSCH e FRANCO, 1992, p. 03. Os autores apresentam mais detalhes sobre a obtenção destas e de outras estimativas.
} 
dois momentos em que vigorou o padrão-ouro no país.

As duas ocasiões em que vigeu o sistema de câmbio fixo a uma paridade ouro (1906-14 e 1926-30) tiveram traços muito semelhantes, no que se refere às condições e aos objetivos pretendidos. Os dois episódios foram precedidos por desequilíbrios macroeconômicos, originados de choques externos, aos quais se seguiram baixas cambiais, como as dos anos 1890, no período do Encilhamento, e de 1921-22, em decorrência da recessão internacional. Os colapsos cambiais tenderam a restaurar um pouco o equilíbrio externo, pela via comercial, ainda que em bases frágeis, devido aos seus efeitos orçamentários (o governo dependia do imposto de importação) e inflacionários. Nessas ocasiões, as autoridades foram induzidas a buscar acomodação financeira no mercado internacional, favorável em ambas as ocasiões, o que resultou nas políticas monetárias muito restritivas de Campos Sales (1898-1902) e Artur Bernardes (1922-26). Nesses períodos deflacionários, a estabilidade foi buscada conscientemente e as recessões foram atenuadas pela melhoria do valor das exportações brasileiras e pelos investimentos induzidos pelo restabelecimento da capacidade de buscar empréstimos externos. ${ }^{37}$ A tendência de apreciação, intencionalmente pretendida, acabava por ser excessivamente reforçada, num mecanismo circular, pois a credibilidade restaurada implicava cada vez mais disponibilidade de divisas no país.

Neste contexto, não era de se estranhar que a adoção do padrão-ouro fosse bem-vinda, com a promessa de coibir novas valorizações excessivas ou "disruptivas" e, dada a posição favorável do balanço de pagamentos, pôr fim ao dinheiro caro (reduzindo juros). Para as autoridades, o padrão-ouro significava credibilidade em mercados de capital, favoráveis nestes dois momentos, o que permitia obter financiamento para obras e reescalonar dívidas. Os mais ortodoxos, defensores das políticas austeras de estabilização de Campos Sales e Artur Bernardes, não se opunham ao padrão-ouro: os conflitos se davam em torno do mecanismo de funcionamento das Caixas de Conversão e Estabilização e do nível ao qual seria estabelecida a paridade. Vale notar que, uma vez adotado, o padrão-ouro tinha um valor político muito grande, o que explica a insistência em mantê-lo, mesmo após a reversão das condições externas favoráveis e à custa de grandes contrações monetárias. Esse valor político está ligado ao compromisso representado pela paridade fixa: o detentor da moeda nacional fica protegido contra perdas advindas da desvalorização cambial. O rompimento com a paridade, por outro lado, provoca uma perda de confiança dos possuidores de moeda, desgastando politicamente a autoridade que venha a romper com o padrão fixado.

Em suma, o padrão-ouro foi adotado no Brasil como resultado de condições externas e

\footnotetext{
${ }^{37}$ FRITSCH e FRANCO, 1992, p. 13.
} 
internas favoráveis: disponibilidade de capitais no mercado internacional, situação folgada do balanço de pagamentos e a preocupação, por parte das autoridades, em restaurar a credibilidade financeira. A uma fase de depreciação cambial, seguia-se um ajuste recessivo, que acabava por gerar pressões excessivas para a valorização, a qual podia ser sustada pelo câmbio fixo lastreado em ouro. Ainda que apresente dados convincentes sobre a política cambial, que não se teria orientado exclusivamente pelos interesses da lavoura cafeeira, desejosa de elevar o valor que recebia em mil-réis pelo café embarcado, o estudo de Fritsch e Franco, limitado por seu foco no mecanismo do padrão-ouro, não se detém sobre o sentido dessa política econômica voltada para o saneamento financeiro e para a moeda estável: frear um processo de valorização cambial era atender aos interesses da economia do café, em sentido lato, ou era uma preocupação das autoridades com uma moeda estável? ${ }^{38}$

Os trabalhos de Renato Perissinotto e de Ana Luíza Backes buscam, a partir de perspectivas metodológicas distintas, aprofundar questões como os conflitos de classe e as clivagens parlamentares do período, propondo interpretações que tentam dar conta das questões levantadas por essa linha revisionista. O estudo de Perissinotto, que lança mão do conceito de fração de classe para entender os conflitos da República Velha, desloca o foco da atenção dos conflitos regionais para os conflitos de classe, especialmente os que se dão no interior da classe dominante, utilizando para isso o conceito de fração de classe. ${ }^{39}$ Nesse sentido, busca-se qualificar categorias comuns na historiografia, como burguesia cafeeira, setor cafeicultor e elite cafeeira: o autor mostra que, no interior desse grupo social vinculado ao café, havia frações de classe distintas, com interesses divergentes e, em certo sentido, antagônicos. O papel hegemônico caberia, neste caso, não à lavoura, mas ao grande capital cafeeiro, isto é, o capital que não se mantinha preso à lavoura, mas se diversificava para outros setores.

Ao longo da primeira metade do século XIX, o investimento fundamental que permitiu essa diversificação fora a ferrovia. À medida que se diversificava a economia cafeeira, sobretudo a partir dos anos 1890, esse capital começava a ser invertido em bancos, casas comerciais (vinculadas ao comércio importador) e empresas de serviço público. ${ }^{40} \mathrm{O}$ grande capital cafeeiro, vale dizer, muitas vezes esteve associado ao capital estrangeiro, por meio do setor bancário e importador. Haveria, pois, um conflito, no interior da classe dominante, entre

\footnotetext{
${ }^{38}$ Em outra oportunidade, é preciso mencionar, Winston Fritsch apresenta uma interpretação do sentido mais geral da política econômica brasileira na Primeira República. Seu argumento é que a instabilidade da demanda internacional (por café) era o principal determinante das medidas tomadas pelas autoridades econômicas neste período. Somada às intempéries naturais internas, essas flutuações da demanda internacional faziam com que os formuladores de política agissem de forma defensiva. Ver FRITSCH, Winston, External constraints on economic policy in Brazil. Houndmills: The Macmillan Press, 1988.

${ }^{39}$ PERISSINOTTO, Renato M. Classes dominantes e hegemonia na República Velha. Campinas: Ed. da Unicamp, 1994.

${ }^{40}$ PERISSINOTTO, 1994, p. 45.
} 
a lavoura e o grande capital cafeeiro, cabendo ao último uma posição hegemônica. O exemplo clássico de representante do grande capital é a família Prado, que era vinculada ao café, mas cujos negócios não dependiam da lavoura em si, diversificados que eram, a ponto de garantir uma rentabilidade independente do preço do café. ${ }^{41}$

O projeto de país vigente na República Velha era, para o autor, um projeto do grande capital cafeeiro - e nesse sentido há uma divergência historiográfica: não é a oligarquia cafeeira que impunha seus interesses, por meio das políticas de proteção ao café, mas, sim, uma fração dessa classe, que não mais é encarada como um todo coeso, capaz de atuação política em favor dos interesses de uma região. $\mathrm{O}$ foco da análise não é mais as fronteiras do estado, de São Paulo no caso, mas as linhas delimitadoras entre os interesses da lavoura e do grande capital cafeeiro.

A política econômica é considerada terreno privilegiado para identificar esses conflitos. No que se refere à política cambial, o argumento de Perissinotto é convergente com o de Fritsch e Franco: para esses autores, não prevaleceu uma política deliberada de desvalorização cambial, nem teria havido uma tendência secular nesse sentido. $O$ câmbio apresentou oscilações e as depreciações mais marcantes, dos anos 1890, de 1915-17 e de 1921-22, teriam tido como causas, respectivamente: as políticas emissionistas da fase do Encilhamento, somadas à crise argentina associada ao Baring; a Primeira Guerra Mundial; e a recessão que atingiu as economias centrais no início dos anos 1920. Por mais que houvesse pressões da lavoura, o Estado muito dificilmente desvalorizaria o câmbio, porque isso o fragilizaria duplamente: pelo lado da receita, proveniente do imposto de importação, e do serviço da dívida denominada em moeda estrangeira. Essas pressões, embora constantes, não eram tão significativas: prevaleciam os interesses do grande capital, ligado ao comércio importador e aos bancos. $^{42}$

Mesmo no que se refere às políticas de valorização do café, Perissinotto identifica um esquema que acaba por privilegiar, no final das contas, o grande capital. Nos momentos de baixa aguda do preço do café, havia uma preocupação comum de sustentar seu preço, afinal

\footnotetext{
${ }^{41}$ A questão da diversificação da economia cafeeira foi abordada de forma mais aprofundada por Flávio Saes (1986) Perissinotto se baseia neste estudo e no de Joseph Love (1982) para compreender a clivagem entre lavoura e grande capital cafeeiro. Para os propósitos deste trabalho, é suficiente pensar a lavoura como os empresários cujos negócios se restringem à produção do café, sem atuação em outras esferas da economia. O grande capital diversificado é um capital acima de tudo comercial, embora vinculado a uma economia de base agrária: extrai sua rentabilidade das ferrovias, da especulação bancária e do comércio importador

${ }^{42}$ Essa visão, corroborada por Fritsch e Franco e por Perissinotto de que a política cambial da República Velha não era favorável à lavoura, sendo a taxa de câmbio fundamentalmente determinada por contingências externas e pelos interesses do grande capital vai na direção oposta da argumentação de Maria Antonieta Leopoldi, que vê a política cambial de Rui Barbosa e Serzedelo Correia, na primeira década republicana, como de cunho claramente industrialista e papelista. Ver LEOPOLDI, Maria Antonieta P. Política e interesses na industrialização brasileira. São Paulo: Paz e Terra, 2000. pp. 160-161.
} 
toda a economia cafeeira, inclusive o grande capital, estava, de alguma maneira, ligada ao café. O modus operandi dos esquemas, contudo, não refletia exatamente os interesses da lavoura: se havia consenso sobre a necessidade de alguma proteção, a forma de estruturar a defesa era objeto de conflito, e nesse conflito prevaleciam os interesses do grande capital. ${ }^{43}$

Um exemplo é a forma como foi definido o comprador que operaria com os estoques de café, no episódio da $1^{\text {a }}$ valorização (1906). Nos termos do Convênio de Taubaté, ficara estabelecido o monopólio estatal da aquisição e comercialização do café, com vistas a proteger os fazendeiros - a chamada "lavoura" - do jogo especulativo feito pelas casas exportadoras. No entanto, prevaleceram as disposições do plano Siciliano, que previam que o monopólio seria exercido por um sindicato de capitalistas, em sua maioria firmas estrangeiras, que, por meio de contrato de seis anos com o estado de São Paulo, centralizariam todas as compras e a comercialização do café, com vistas a elevar seu preço. ${ }^{44}$ Outra medida importante na valorização de 1906-08 foi a adoção do câmbio fixo, nos termos do padrãoouro referidos acima: a taxa, proposta pela lavoura, de 12 pence por mil-réis não foi atendida, ficando em 15 pence por mil-réis. Era uma taxa que buscava conciliar interesses agrários, comerciais, financeiros e industriais. Não era, portanto, a taxa propugnada pela lavoura. Nas outras valorizações do café, a composição de interesses seria semelhante: as medidas tomadas favoreciam os capitalistas ligados à produção, mas sem atender integralmente a suas reivindicações.

A burguesia industrial começava a constituir-se, na Primeira República, como uma fração de classe importante, que começou a ser representada por associações como o Centro Industrial do Brasil, fundado no Rio de Janeiro e, em São Paulo, a Associação Comercial. Uma importante bandeira dos defensores da indústria no início do período republicano foi a proteção tarifária. Com o advento da República, os industrialistas passaram a ganhar mais espaço, ocupando cadeiras no Congresso e participando diretamente das comissões de tarifas. A questão tarifária passou a estar mais presente na imprensa, à medida que a elite industrial se ampliava e passava a incluir diferentes profissionais (engenheiros, militares, industriais e parlamentares). A tarifa de 1895-96 é considerada a primeira tarifa protecionista, tendo sido elaborada sob pressão dos industrialistas. Foi revisada logo em seguida. A tarifa que perdurou durante boa parte da República Velha foi a de 1900, que não tinha intenção claramente

\footnotetext{
${ }^{43}$ Essa forma de funcionamento das políticas de valorização, baseada no atendimento parcial às reivindicações da lavoura, com prevalência dos interesses do grande capital, só pode ser identificada, segundo o autor, na $1^{\text {a }}(1906-08)$ e na $3^{\text {a }}$ valorização (1921-23) e na estruturação da defesa permanente do café. Para o detalhamento das medidas tomadas em cada ocasião, ver PERISSINOTTO, 1994, cap. 02.

${ }^{44}$ O plano Siciliano foi apresentado por Alexandre Siciliano à Sociedade Paulista de Agricultura em 1903, tendo recebido o apoio desta entidade e de figuras importantes como Antonio Prado. Sobre as diferenças entre o plano e o Convênio de Taubaté, ver PERISSINOTTO, 1994, pp. 69-77.
} 
protecionista, mas restabelecia a quota-ouro (medida que visava compensar os efeitos da desvalorização cambial sobre a arrecadação estatal), não sendo de todo desfavorável à indústria. $^{45}$

Foi na Primeira República que o empresariado industrial começou a se organizar em associações, conformando um grupo mais coeso, sobretudo a partir dos anos 1920. O marco inicial desse associativismo foi, segundo Leopoldi, a fundação do Centro Industrial do Brasil (CIB), em 1904, por Serzedelo Correia, que foi a primeira entidade de classe permanente da indústria, organizada sem interferência estatal. Foi o resultado da fusão da Sociedade Auxiliadora da Indústria Nacional (SAIN) com o Centro de Fiação e Tecelagem do Rio de Janeiro. A SAIN (1827-1904) fora uma entidade de caráter consultivo. Identificada com a Monarquia, a entidade deu voz, em seu período áureo (anos 1870), aos fazendeiros do Sudeste, que debateram a questão da mão-de-obra escrava. Sua publicação $O$ Auxiliador da Indústria Nacional veiculou, neste mesmo período, debates entre defensores do protecionismo tarifário à indústria e livre-cambistas. ${ }^{46}$

Em São Paulo, a entidade que congregava os industriais era a Associação Comercial, fundada em 1894, com 152 associados, entre comerciantes e industrialistas, número que cresceria para 1118 em 1914. No Rio, a entidade agregadora - o CIB - precedera as associações setoriais, ocorrendo o contrário em São Paulo, onde o Centro das Indústrias de Fiação e Tecelagem de Algodão (CIFTSP), surgiu em 1919, antes do Centro das Indústrias do Estado de São Paulo, que congregaria a indústria paulista. O CIESP foi fundado a partir da ruptura dos industriais com a Associação Comercial, por divergências de interesses relacionados a políticas cambiais e tarifárias. Roberto Simonsen teve papel importante nesse movimento, como será discutido mais adiante, quando for analisado o discurso proferido por Simonsen na ocasião, em 1928.

Ainda que a indústria tenha se estabelecido como setor importante da economia nacional, ao longo da Primeira República, não se pode dizer que seus interesses tenham prevalecido sobre os aqueles ligados à economia agroexportadora como um todo: tanto os interesses da lavoura quanto os do grande capital, de base mercantil, cuja rentabilidade provinha sobretudo do setor bancário-financeiro e do comércio de importação e exportação. O próprio Simonsen afirmava, em 1918, que o Brasil deveria desenvolver sua agricultura, pois fora este o setor fundamental que proporcionara, à indústria norte-americana suas matérias-primas e seus

\footnotetext{
${ }^{45}$ Sobre a política tarifária e as reivindicações da burguesia industrial, ver LEOPOLDI, 2000, cap. 3 e PERISSINOTTO, 1994, pp. 138-146.

${ }^{46}$ LEOPOLDI, 2000, pp. 62-65.
} 
capitais. $^{47}$

\begin{abstract}
A indústria era, a um só tempo, setor significativo e subordinado, com interesses próprios mas sem condições de elaborar e apresentar um projeto hegemônico de sociedade alternativo ao projeto agroexportador; defendia seus próprios interesses mas não um programa industrialista alternativo à economia agroexportadora; organizava-se em associações de classe, mas não constituiu um partido político autônomo; criticava a preponderância da sociedade agroexportadora e monocultora mas não aderiu à Revolução de $30 .{ }^{48}$
\end{abstract}

Se Perissinotto mostra a prevalência dos interesses da fração de classe constituída pelo grande capital mercantil, deslocando o foco da questão regional para os conflitos de classe, seu trabalho se refere quase exclusivamente ao grande capital mercantil ligado à economia cafeeira do estado de São Paulo. Nesse sentido, não fica claro o que dava estabilidade nacional ao regime da Primeira República: para os historiadores dos anos 1960-70, como vimos, tratava-se de um acordo entre as elites regionais dirigentes, cuja garantia era a política dos governadores. O trabalho de Ana Luíza Backes, que segue essa mesma linha revisionista de estudo do período, busca reinterpretar o pacto de Campos Sales, que instituiu a política dos governadores, dando ênfase ao seu caráter nacional, isto é, mostrando que tal política significou uma unidade política nacional em torno de um projeto específico, que, embora a autora não o diga com todas as letras, é claramente ligado aos interesses econômicos do grande capital mercantil associado. ${ }^{49}$

A autora se baseia principalmente nos debates ocorridos na Câmara, no Senado e na Constituinte de 1891 para argumentar que as interpretações tradicionais, que enfatizam o caráter oligárquico e regionalista da política da Primeira República não são suficientes para se entender o pacto político estabelecido por Campos Sales, com seu plano de austeridade econômica e o estabelecimento da política dos governadores. Não se nega a preponderância dos interesses das elites ligadas ao café, nem a preponderância de São Paulo, mas enfatiza-se o fato de Campos Sales ter conseguido unir um Congresso dividido, sob a hegemonia do projeto dos republicanos históricos, derrotando o projeto dos "concentrados" (herdeiros do florianismo). Importa frisar que se tratava de um projeto de modernização conservadora, baseado em criar a ordem, para depois gerar o progresso. Era necessário, para este projeto, saneamento financeiro, orçamentos equilibrados e uma moeda forte e estável, para que se pudesse atingir alguma modernização econômica, que ocorreria com o auxílio do capital estrangeiro. Este projeto de modernização conseguiu atrair o apoio, inclusive, de deputados ligados à indústria, como Serzedelo Correia e Alcindo Guanabara. O estudo qualifica a ideia

\footnotetext{
${ }^{47}$ SIMONSEN, $1918 \mathrm{~b}$.

${ }^{48}$ PERISSINOTTO, 1994, p. 130.

49 BACKES, Ana Luíza. Fundamentos da ordem republicana: repensando o Pacto de Campos Sales. Brasília: Plenarium, 2006.
} 
de descentralização política, mostrando que houve, sim, um projeto que recebeu apoio político nacional: esse projeto não era nem da lavoura cafeeira e nem da indústria, mas esses setores o apoiaram.

\begin{abstract}
A nova elite no poder pretende 'modernizar' o país, mostrando seriedade e competência para atrair o capital estrangeiro. No entanto, é ela quem comanda, os dirigentes não são títeres do capital internacional. A política econômica é decorrente de um projeto de modernização conservadora, que procurou promover o desenvolvimento do país com o auxílio do fluxo internacional de capitais. ${ }^{50}$
\end{abstract}

Esse projeto de modernização parece claramente vinculado ao capital mercantil, mais que à indústria ou à lavoura. A ideia de modernização, como forma de entender uma etapa da formação econômica do Brasil, é convergente com o conceito de Celso Furtado, referido acima. ${ }^{51}$ Para este autor, diferentemente do que ocorreu nas regiões centrais do capitalismo, em que a assimilação do progresso técnico se dava por meio da incorporação e desenvolvimento das forças produtivas, em economias periféricas com o Brasil, este processo ocorre via transformações nos padrões de consumo. A dinâmica desse processo se dava a partir da conversão das rendas geradas nos setores agroexportadores na incorporação de padrões de consumo típicos dos países centrais. É um processo de modernização, porque promove o crescimento econômico e eleva a satisfação das classes mais abastadas: os que têm a possibilidade de incorporar padrões de consumo de países centrais são aqueles que auferem a maior parte da renda proveniente da agroexportação. Entretanto, esse mecanismo de modernização pela imitação exige cada vez mais recursos da sociedade para manter seu dinamismo, na medida em que torna a economia ainda mais vulnerável externamente.

Um importante meio pelo qual esse processo de modernização entrou no Brasil foi a oferta de serviços e a construção de melhorias nos centros urbanos, principalmente no Rio de Janeiro e em São Paulo. Esses serviços e melhorias geravam externalidades importantes para a indústria: a instalação de rede elétrica para iluminação e transportes, por exemplo, significou a geração de capacidade energética que alimentou a indústria que se instalava. Desse modo, a modernização, no sentido furtadiano, esteve associada ao crescimento industrial, mas este ainda se manteve, ao longo da Primeira República, rigorosamente dependente do desempenho da economia primário-exportadora, pois era restringido pela natureza periférica e limitada do processo: os padrões de consumo das classes altas se sofisticavam, mas, para suprir essa nova demanda, era necessária uma tecnologia e um equipamento industrial inexistentes no Brasil, o que tornava o processo intrinsecamente dependente da geração de divisas via exportação de primários. $\mathrm{O}$ avanço industrial esteve, também, crescentemente associado ao capital

\footnotetext{
${ }^{50}$ BACKES, 2006, p. 281.

${ }^{51}$ FURTADO, Celso. O mito do desenvolvimento econômico. Rio de Janeiro: Paz e Terra, 1974.
} 
estrangeiro, que, articulado à economia nacional, era um agente promotor do referido processo de modernização. ${ }^{52}$

Dentro desse projeto de modernização, associado aos interesses de um capital que é mais mercantil do que propriamente ligado à produção agrícola ou industrial, a atuação de Roberto Simonsen, ao longo da República Velha, não pode ser associada à defesa de um projeto industrialista, nem a um nacionalismo econômico sólido, mesmo que Simonsen fosse um ator importante no processo de construção da consciência industrialista. Isso ficará claro a partir da análise de seus textos, em especial aqueles anteriores aos meados da década de 1920. Tanto a formação acadêmica de Simonsen quanto várias atividades que exerceu no período eram relacionadas com essa ideia de modernização.

Simonsen se formou pela Escola Politécnica de São Paulo, na turma de 1909. A própria criação da Politécnica, em 1893, inspirada no modelo do Polytechnikum de Zurique, mostra a busca, por parte da elite de São Paulo, de dotar o estado de uma instituição nos moldes europeus. A Escola deveria veicular um conhecimento técnico, que refletisse os avanços tecnológicos da Segunda Revolução Industrial, muito embora no Brasil a industrialização ainda estivesse em estágios iniciais, desenvolvendo-se sobre uma base técnica pouco sofisticada para os padrões da época. A formação de engenheiro civil na Politécnica significou, para Simonsen, o contato com um tipo de conhecimento específico, ligado ao projeto de modernização da elite paulista. No capítulo seguinte, trataremos do conhecimento econômico veiculado na Escola Politécnica, neste início do século XX.

A vida profissional de Simonsen se iniciou, talvez por influência do avô materno ${ }^{53}$, na Southern Brazil Railway, onde trabalhou de 1909 a 1910. Entre 1911 e 1912, trabalhou na Prefeitura de Santos, como diretor-geral e, depois, engenheiro-chefe da Comissão de Melhoramentos do Município de Santos. Nessas funções, organizou um plano de melhoramentos da cidade, que incluía recalcamento de ruas, drenagem de águas pluviais e estudos sobre passeios e arborização. Em 1912, retirou-se da prefeitura para fundar, com alguns amigos, aquela que seria a célula-mãe de suas empresas: a Companhia Construtora de Santos. 54

\footnotetext{
${ }^{52}$ SAES, Alexandre Macchione. Conflitos do capital. Bauru: Edusc, 2010. cap. 05.

${ }^{53}$ Simonsen fez os estudos secundários no Ginásio Anglo-Brasileiro, tendo mudado de Santos para São Paulo, para morar com o avô materno. $\mathrm{O}$ avô de Roberto Simonsen, o engenheiro Wallace da Gama Cochrane, trabalhou nas estradas de ferro Central do Brasil e Santos-Jundiaí. Wallace Cochrane foi deputado à Assembleia Legislativa Provincial de 1870 a 1879 e fez parte da primeira diretoria da Companhia Paulista de Estradas de Ferro. Ver LIMA, Heitor Ferreira. 3 industrialistas brasileiros: Mauá, Rui Barbosa, Simonsen. São Paulo: Alfa-Ômega, 1976.

${ }^{54}$ Anuario da Escola Polytechnica de São Paulo - 1909. Arquivo Histórico da Escola Politécnica. Ver, também, SANTOS, Maria Cecília Loschiavo dos. Escola Politécnica da Universidade de São Paulo (1894-1984). São Paulo: Reitoria da USP/EPUSP, 1985. pp. 46-48; e AIDAR, José Luiz; CYTRYNOWICZ, Roney; ZURQUIM, Judith. Escola Politécnica 100 anos. São Paulo: Expressão e Cultura, 1993.
} 
Esta Companhia construiu diversas residências, vilas operárias, armazéns, teatro, matadouro, frigoríficos, igrejas, campos esportivos, bancos, bem como obras de calçamento de ruas. Numa tentativa de "criar mercado" para as realizações da Companhia, foram organizados outros empreendimentos, sempre com participação da empresa principal: apareceram, então, a Companhia Santista de Habitação Econômica, a Companhia Parque Balneário, a Companhia Brasileira de Calçamentos e a Companhia Frigorífica de Santos. Obras marcantes dessas empresas, no município de Santos, são o monumento aos Andradas, o edifício da Bolsa do Café e o bairro operário de Vila Belmiro.

Fora de Santos, as obras mais destacadas do grupo empresarial de Simonsen foram os quartéis construídos para o Exército, entre 1922 e 1923. As obras para o Exército foram de porte considerável, chegando a empregar, em alguns meses, mais de 15.000 operários espalhados pelo território nacional. Foram construídos quartéis no Distrito Federal, Rio de Janeiro, São Paulo, Goiás, Mato Grosso, Minas Gerais, Paraná, Santa Catarina e Rio Grande do Sul. Este episódio da construção dos quartéis pela Companhia Construtora de Santos foi relatado por Simonsen em livro de 1931, cujo objetivo era a defesa contra críticas, circulantes à época, de que haveria favorecimento nos contratos firmados entre a Companhia e o governo federal. As obras foram contratadas por Pandiá Calógeras, ministro do governo de Epitácio Pessoa. Tiveram início em 1921 e foram suspensas em 23 dezembro de 1924 por decreto presidencial. Os motivos para a suspensão, alegados por Simonsen, para a paralisação das obras eram a instabilidade reinante no Rio Grande do Sul, onde se concentravam as obras ainda em andamento, e as dificuldades financeiras do Tesouro Nacional. Das 53 obras contratadas, Simonsen registra que 38 haviam sido entregues até meados de $1924 .{ }^{55}$

Roberto Simonsen era um empresário inserido na lógica vigente da modernização que ocorreu no Brasil da Primeira República: o Palácio da Bolsa do Café, construído por sua Companhia, é um edifício emblemático da força hegemônica do grande capital mercantil, ligado à economia cafeeira. Boa parte das obras da Companhia Construtora de Santos era constituída por melhorias urbanas, voltadas para as classes abastadas, em uma cidade dominada pelo capital mercantil ligado ao café. Principal porto de escoamento do café, Santos viveu intensas transformações no começo do século XX, dentro do processo de modernização pela via da imitação e da incorporação de novos padrões de vida, por parte das elites. A Bolsa do Café teria sido um marco urbano desse processo de modernização: de acordo com Ana Lanna, o Palácio da Bolsa refletia o projeto da elite cafeeira, que vinculava a produção de riqueza ao campo, sendo a cidade o lugar do comércio e do dispêndio determinado por

\footnotetext{
${ }^{55}$ SIMONSEN, Roberto. A construção de quartéis para o Exército. São Paulo: sem editora, 1931. pp. 111-114.
} 
padrões imitados do estrangeiro.

\begin{abstract}
A proposta elaborada por essa elite [cafeeira] compreendia um campo produtor onde residiria a maioria dos trabalhadores, inclusive imigrantes. Contraposta e vinculada a esse universo rural, a cidade aparecia formulada utopicamente como lugar de comércio e consumo, europeizada, lugar privilegiado das elites e de uma população trabalhadora necessária mas colocada sob severos controles e restrições. Não por acaso as esculturas que adornavam a fachada do edifício [da Bolsa] simbolizavam a agricultura e o comércio. A cidade aparecia no Palácio apenas através dos painéis internos executados por Benedito Calixto. ${ }^{56}$
\end{abstract}

Como ficará claro a partir da análise dos textos escritos nesse período, Simonsen era, nesses anos iniciais do século XX, um empresário preocupado com questões de eficiência e organização produtiva, no âmbito de suas empresas, mas não havia um questionamento da lógica da economia agroexportadora, nem uma ideia de atraso a ser superado pela via da industrialização. Sua atuação como empresário se dava no sentido de participar do processo de modernização em curso, sem que esse processo em si fosse questionado de forma contundente, como será feito em momentos posteriores.

Em 1919, Simonsen foi convidado pelo Ministro da Agricultura Pádua Sales a integrar a missão comercial brasileira em viagem à Inglaterra, chefiada por João Pandiá Calógeras. Esta viagem projetou Roberto Simonsen na cena política nacional: de fato, ao longo da estada na Europa, Simonsen pronunciou discursos que tinham uma perspectiva mais abrangente da economia nacional. Contudo, eram textos que versavam sobre possibilidades de crescimento da economia brasileira, articulada à divisão do trabalho vigente naquele momento: os temas eram indústria frigorífica, possibilidades algodoeiras e madeireiras do Brasil - em suma, discutia-se o fomento à produção de gêneros exportáveis para a Inglaterra.

Um exemplo do tipo de questão que interessava a Simonsen nesse momento é a controvérsia sobre o asfaltamento em São Paulo, entre o próprio Simonsen e Victor da Silva Freire, que se deu na imprensa paulistana e resultou na publicação de um pequeno volume, em 1923, contendo os pareceres trocados entre os dois engenheiros. ${ }^{57}$ A discussão se dava em torno do tipo de calçamento que deveria ser utilizado na cidade de São Paulo, no início da década de 1920. A participação de Roberto Simonsen no episódio se deu por meio de uma controvérsia com o engenheiro e professor da Escola Politécnica Victor da Silva Freire, em

\footnotetext{
${ }^{56}$ LANNA, Ana Lúcia Duarte. “A transformação urbana: Santos 1870-1920”. IN: Revista USP. n. 41, março-maio. São Paulo: USP, 1999.

${ }^{57}$ SIMONSEN, Roberto e QUEIROZ, Luiz Augusto Pereira. O calçamento de asphalto em São Paulo. São Paulo: Typographia Brazil de Rothschild, 1923. O livro contém os seguintes artigos: 1. "O asphaltamento de São Paulo", originalmente publicado no "Estado de São Paulo", de 23 e março de 1923. 2. "A questão do asphalto", originalmente publicado no "Estado de São Paulo", de 25 de março de 1923. 3. "O asphaltamento de São Paulo", publicado no "Estado de São Paulo", em 17 de abril de 1923.
} 
torno de uma questão puramente técnica, travada nos termos da época e utilizando referências estrangeiras, sobretudo americanas e francesas. O objeto da polêmica é a atribuição dos problemas existentes no calçamento de São Paulo ao tipo de betume utilizado na composição da massa asfáltica. Sem entrar nos pormenores da discussão, de resto técnica e datada, convém ressaltar que a controvérsia resvala para uma oposição entre uma postura mais empírica, defendida por Silva Freire, e uma posição mais científica, mais valorizadora dos "testes realizados em laboratório", que era a de Roberto Simonsen.

Para além do conteúdo em si, de caráter técnico, vale observar que Victor da Silva Freire era, à altura, o Diretor de Obras Públicas da Municipalidade de São Paulo, responsável por implantar importantes medidas urbanísticas na São Paulo de início do século XX. Essas medidas estariam vinculadas a um projeto de higienização urbana, por meio da implantação de um projeto de cidade salubre. Teria sido Freire o responsável pela introdução, na legislação municipal paulistana, dos conceitos de "isolação" e "aeração", que operaram modificações importantes na paisagem urbana, como alterações no formato das janelas, que permitissem uma melhor ventilação, dentro da ideia de casa salubre. Também se credita a Victor da Silva Freire o plano do Vale do Anhangabaú, que deveria ser uma espécie de pulmão, higienizando o triângulo central paulistano e tornando a área um local de recreio e usufruto estético. ${ }^{58}$

A discussão com Victor da Silva Freire, travada em público, no "Jornal do Commercio" e no "Estado de São Paulo", entre março e abril de 1923 se dá sobre um tema diretamente ligado ao processo de modernização vivido pelo Brasil neste momento: a preocupação, tanto de Simonsen quanto de Silva Freire, era bem aplicar os princípios consignados nos manuais americanos e franceses ao calçamento paulistano. O próprio projeto de higienização urbana levado a cabo por Victor da Silva Freire em São Paulo, semelhante ao que também se implementava no Rio de Janeiro, é exemplar desse período de modernização que passa pelos serviços urbanos e pela imitação de padrões de vida estrangeiros. Simonsen, como se observou, entra no debate como opositor a Silva Freire, mas está inserido nesta lógica de pensamento.

No último parecer sobre asfaltamento, publicado em 1923, Simonsen assumiu uma postura menos técnica e mais nacionalista ao rebater declaração do vereador Orlando de Almeida Prado, em apoio à lei que nomeava Victor da Silva Freire representante brasileiro no Congresso Internacional de Estradas, a realizar-se em Sevilha. O argumento favorável à lei era que o Diretor de Obras Públicas encontraria, no evento, subsídios adequados para a abertura de uma concorrência pública de asfaltamento "em virtude da falta patente,

\footnotetext{
${ }^{58}$ Ver SIMÕES JUNIOR, José Geraldo. “A pesquisa e o debate urbanístico em São Paulo (1900-1920): as proposições em torno do tema da 'casa e cidade salubres"'. IN: Arq.urb. n. 01. São Paulo: USJT, 2008.
} 
indiscutível, de individualidades nacionaes, familiarisadas com assumpto de tal modo especial". ${ }^{59}$ Simonsen respondeu que essa postura, que refletia o pensamento do Diretor Silva Freire, só fazia amesquinhar o papel da engenharia brasileira e as instituições técnicas do país. "Para se poder julgar de uma sciencia e tambem do valor da sua applicação, não são indispensaveis congressos internacionaes em que se tratam os assumptos sob um caracter muito geral e vago, e aos quaes as adhesões de interessados são voluntarias e facultativas". 60 Esses pareceres são representativos das preocupações de Simonsen nesse momento: há alguns traços de nacionalismo, mas ainda inseridos na lógica da modernização do início do século $\mathrm{XX}$, desvinculada de um projeto industrialista.

Ainda no período da Primeira República, a situação começou a alterar-se, no sentido de uma preocupação maior, por parte de Simonsen, com problemas nacionais e da incorporação de questões relativas à industrialização em meados da década de 1920, num processo correlato à diversificação industrial que ocorreu no Brasil nesses anos. Segundo Wilson Suzigan, o período 1919-1929 foi um momento em que o investimento industrial se elevou em praticamente todos os setores. Ramos tradicionais, como têxteis, calçados e alimentação tiveram sua capacidade ampliada e/ou modernizada. No ramo têxtil, além da ampliação da tecelagem de algodão, introduziu-se a fabricação de seda artificial (raiom). Os setores de moagem de trigo, açúcar e cerveja realizaram grandes investimentos. Para além da ampliação do parque já existente, houve um processo de diversificação significativo. A primeira fábrica de cimento bem-sucedida foi construída em 1924-1926 e foram construídas cinco usinas siderúrgica, das quais três foram exitosas. No ramo metal-mecânico, o investimento ampliouse, com o início da produção de máquinas agrícolas pesadas e equipamento industrial leve. Indústrias que se instalaram no parque brasileiro nos anos 1920 incluem borracha, química, farmacêutica e perfumaria. ${ }^{61}$

A participação de Simonsen nesse momento de diversificação é atestada pelos cargos que assumiu no período. Em 1923, assumiu a presidência do Sindicato Nacional dos Combustíveis Líquidos e, no ano seguinte, passou a dirigir a Cerâmica São Caetano. Em 1926, organizou a Companhia Nacional da Borracha e a Companhia Nacional de Artefatos de Cobre. Simonsen também ingressou no comércio de café, tendo fundado, em sociedade com o cunhado, Edwin Murray, a Casa Comissária Murray, Simonsen e Cia. Ltda. que representou os Lazard Brothers, banqueiros ingleses financiadores do Instituto Paulista de Defesa do Café, durante o governo Washington Luís.

\footnotetext{
${ }^{59}$ SIMONSEN, 1923, p. 124.

${ }^{60}$ SIMONSEN, 1923, p. 124.

${ }^{61}$ SUZIGAN, Wilson. Indústria brasileira: origem e desenvolvimento. São Paulo: Hucitec/Unicamp, 2000. pp. $90-92$.
} 
Durante esse período dos anos 1920, Simonsen se afirmou como industrial importante, mas seu projeto intelectual e de país, ainda era mais ligado à ideia de modernização e de aprofundamento do processo em curso de crescimento de certos setores da economia, do que à noção de superação de uma estrutura atrasada por meio do processo de industrialização. A hegemonia, econômica e política, do grande capital mercantil, diretamente dependente da produção agroexportadora, não dava condições de possibilidade a uma atuação política e intelectual mais marcadamente voltada para a indústria e para seu papel na superação do atraso brasileiro. O distanciamento de Simonsen com relação a essa visão modernizadora, mas não exatamente desenvolvimentista, no sentido de Bielschowsky ${ }^{62}$, não coincide exatamente com as rupturas econômicas e políticas do Brasil, mas está, em certa medida, relacionadas com elas.

Essa mudança intelectual foi um processo de elaboração que se deu entre meados dos anos 1920 e o início dos anos 1930. Mesmo no conhecido discurso de fundação do CIESP (1928), analisado mais adiante, que é uma peça importante de questionamento à ideia da “indústria artificial”, ainda estava presente a concepção de que o Brasil era um país agrícola. A categoria "atraso econômico", por exemplo, e sua associação às produções de base colonial ou primário-exportadora não tinha lugar importante nas produções de Simonsen anteriores aos anos 1930. Foi nesses anos, sobretudo no período do Estado Novo, que Simonsen, industrial já estabelecido, se consolidou como intérprete do Brasil, aprofundando o estudo do protecionismo e do planejamento e formulando seu pioneiro ensaio de interpretação de nossa história econômica. A próxima seção dedica-se a este período, que começa a partir do movimento político iniciado com a sucessão de Washington Luís e que culminou com a ascensão de Getúlio Vargas ao poder, marcando o início de uma era de transformações econômicas e políticas que impactaram o desenvolvimento industrial brasileiro, de forma geral, e a trajetória de Simonsen em particular.

\subsection{Da Revolução de 1930 ao Estado Novo: um novo tipo de atuação}

A interpretação da chamada Revolução de 1930 e do Estado que a partir dela se construiu no Brasil é objeto de debate na historiografia brasileira. ${ }^{63}$ A questão central, sobre a qual se debruçam vários trabalhos relativos às relações entre Estado, economia e sociedade

\footnotetext{
${ }^{62}$ Desenvolvimentismo é entendido aqui no sentido atribuído por Bielschowsky: ideologia de transformação social, baseada na industrialização integral e na convicção de que seria impossível atingir essa industrialização somente pelas forças do livre mercado. BIELSCHOWSKY, Ricardo. Pensamento econômico brasileiro: o ciclo econômico do desenvolvimentismo. Rio de Janeiro: Contraponto, 2000. p. 7.

${ }^{63}$ FAUSTO, Boris. A revolução de 1930: historiografia e história. [1969]. 16 ed. 1997. pp. 29-36, pp. 34 a 36. Veja-se, em especial, o "Prefácio à edição de 1997" (pp. 11-27), no qual o autor faz uma síntese das contribuições mais recentes à historiografia da Revolução de 1930.
} 
engendradas pela Revolução de 30, é a associação desse movimento de ruptura política a uma classe social específica e, por extensão, a um projeto específico de país. A partir dos anos 1930, a participação de Roberto Simonsen na política e na esfera pública tornou-se mais constante e mais enfática, no sentido da defesa dos interesses industriais. Contudo, não se deve correlacionar, de forma imediata, a mudança de regime com uma viabilidade maior dos interesses de classe dos industriais, que Simonsen passou a representar. O CIESP, do qual Simonsen era vice-presidente quando da Revolução de 1930, apoiou Júlio Prestes à presidência da República, na condição de representante da elite paulista. No final do Estado Novo, todavia, encontramos Simonsen no Conselho Nacional de Política Industrial e Comercial, órgão ligado à Presidência da República, formulando propostas de planificação que, se não foram totalmente postas em prática, foram, sem dúvida, levadas a sério, como fica claro no debate travado com Eugênio Gudin.

Não deixa de ser intrigante que Roberto Simonsen, que se posicionou contrariamente à eleição de Vargas e esteve ao lado da Frente Única Paulista, de oposição ao governo federal em 1932, tenha ocupado postos importantes no âmbito da administração de Vargas, alguns anos mais tarde, influenciando o debate de política econômica em nível nacional. Ainda que admita respostas variadas, uma possível explicação para essa indagação parece relacionada com o tipo de representação que o governo Vargas abriu para a burguesia industrial, sobretudo a partir do Estado Novo, mas já antes da sua implantação. Essa representação, baseada nos Conselhos Técnicos, diretamente vinculados ao poder executivo e dissociada de processos de eleição democrática, garantia aos industriais uma participação política estratégica, permitindo-lhes e defender seus interesses de classe a partir de posições mais influentes.

Durante o movimento constitucionalista em São Paulo, Simonsen presidiu a Comissão de Cadastro e Mobilização Industrial e integrou o Conselho Consultivo-Econômico do Estado, o Departamento Central de Munições e o Conselho de Assistência Civil. Com a redemocratização, em 1933 Simonsen foi escolhido como deputado classista, representante dos industriais paulistas nas eleições para a Assembleia Nacional Constituinte. Teve seu mandato renovado em 1934, tendo participado ativamente da legislatura vigente no período democrático do governo de Vargas: colaborou em estudos de problemas econômicos e sociais e fez parte da Comissão Especial de Leis Complementares da Constituição e as comissões de Legislação Social e de Diplomacia e Tratados. Também participou dos códigos de Águas, do Ar e dos Serviços Industrializados. Participou ativamente do debate em torno da ratificação do Tratado Comercial com os Estados Unidos, em 1935. 
Eleito presidente da FIESP em 1937, Simonsen passou a fazer parte, como substituto de Euvaldo Lodi, do Conselho Federal de Comércio Exterior (CFCE), órgão diretamente ligado ao presidente Vargas, cujas funções de fato excediam a área do comércio exterior: era um órgão de formulação de política econômica no geral. Sua participação no CFCE resultou na publicação de um livro, no mesmo ano de 1937, intitulado A indústria em face da economia nacional. Os pareceres feitos para o CFCE se referem a temas diversos, como transporte ferroviário, mineração de diamantes e política algodoeira. ${ }^{64}$ Com a implantação do Estado Novo, em novembro de 1937, Simonsen perdeu sua cadeira de deputado, mas não se opôs à nova administração. Na introdução do referido livro, datada de novembro de 1937 Simonsen apresentou uma justificativa para seu apoio ao regime ditatorial:

\begin{abstract}
As condições de insegurança e de intranquilidade, provocadas por uma campanha demagogica e insincera e o emperramento creado de um lado pela burocracia e de outro pelos processos observados no Poder Legislativo, estavam a reclamar providencias de caracter inadiavel e necessarias ao progresso do paiz. Essas medidas de excepcional gravidade estão assim justificadas. ${ }^{6}$
\end{abstract}

O fato de Simonsen ter incluído, em seu livro, uma "justificativa" para o apoio ao novo regime é indicativo de que ele próprio considerava necessário apresentar um motivo para a mudança de posição política. As razões apresentadas - insegurança e intranquilidade - fazem coro à retórica do momento e não contribuem muito para a explicação do episódio. $\mathrm{O}$ apoio de Simonsen ao Estado Novo nos parece relacionado com a natureza do regime implantado e com as possibilidades abertas por ele. A partir de 1937, Simonsen ficaria cada vez mais próximo do círculo de empresários e técnicos ligados a Getúlio Vargas. ${ }^{66}$

Em 1938, foi reeleito à presidência da FIESP, provocando um movimento de protesto que resultou no desligamento de 297 empresas filiadas à entidade, inclusive as tradicionais indústrias de Francisco Matarazzo. Esse é um movimento curioso, captado por Vera Cepêda: à medida que se aproximava do aparelho do Estado e torna-se defensor de um intervencionismo estatal mais radical, Simonsen perdia o apoio de alguns seus pares industriais. Seria um limite da ideologia industrialista brasileira, incapaz de assumir posições mais enfáticas na arena política. ${ }^{67}$

Durante a Segunda Guerra Mundial, em novembro de 1942, Simonsen foi nomeado para o conselho consultivo da Coordenação de Mobilização Econômica, cujo objetivo era organizar a economia de guerra. Este órgão ganhou o status de um superministério,

\footnotetext{
${ }^{64}$ SIMONSEN, Roberto. A indústria em face da economia nacional. São Paulo: Graphica da "Revista dos Tribunaes", 1937.

${ }^{65}$ SIMONSEN, 1937, p. 23.

${ }^{66}$ A maioria dos dados biográficos desta seção está em: DIAS, Sônia, "Roberto Simonsen". IN: Dicionário histórico-biográfico brasileiro: pós-1930. 2. ed. Rio de Janeiro: FGV/CPDOC, 2001. pp. 5481-5485.

${ }^{67}$ CEPÊDA, Vera Alves. Roberto Simonsen e a formação da ideologia industrial no Brasil: limites e impasses. São Paulo: FFLCH/USP, 2003. Tese de Doutorado.
} 
absorvendo parte das funções do CFCE e passando a controlar a carteira de crédito do Banco do Brasil. Em 1943, Roberto Simonsen integrou a Comissão do Imposto Sindical e participou do I Congresso Brasileiro de Economia. Nomeado para o Conselho Nacional de Política Industrial e Comercial (CNPIC), em 1944, Simonsen elaborou o relatório que seria o documento inicial da conhecida controvérsia sobre o planejamento, com Eugênio Gudin, a esta altura membro da Comissão de Planejamento Econômico. Esse importante debate, que envolveu, em 1945, uma resposta de Gudin seguida de réplica e tréplica, será analisado no capítulo 3. Neste ano, Simonsen participou da I Conferência das Classes Produtoras, em Teresópolis (RJ), na qual defendeu a criação de um Ministério da Economia, voltado para o desenvolvimento econômico, separado do já existente Ministério da Fazenda. Com o fim do Estado Novo e o interregno do governo Dutra, Simonsen passou a atuar, até seu falecimento, em 1948, em órgãos como o recém-formado Partido Social-Democrático (PSD), legenda pela qual elegeu-se senador por São Paulo em 1947.

A partir da participação no CFCE, em 1937, Simonsen foi se aproximando do governo Vargas, do qual inicialmente fora um opositor, chegando a ocupar posições de relevo no Estado, em nível federal. Parte-se aqui da ideia que este movimento de Simonsen esteve relacionado, não apenas com um sentimento de insegurança com relação à manutenção da ordem e da institucionalidade da época, mas, também, com as mudanças na estrutura do Estado brasileiro, ocorridas a partir de 1930 e intensificadas com o Estado Novo, que acabaram por lhe permitir uma participação mais efetiva no debate sobre a política econômica no Brasil. Nesse sentido, é oportuno percorrer algumas interpretações do processo histórico de constituição desse Estado que deu condições de possibilidade ao discurso e ao projeto industrialista, do qual Simonsen foi se tornando representante destacado.

Historiadores de orientação marxista, entre os quais se destaca Nelson Werneck Sodré, tenderam a ver em 1930 o marco da ascensão da burguesia industrial ao poder no Brasil, sendo o Estado que aí se instituiu uma expressão dos interesses burgueses. A partir de uma conceituação marxista, essa linhagem caracteriza os acontecimentos de 1930 como um imperativo histórico de adaptar o aparelho do Estado às necessidades da expansão burguesa. Contudo, esse processo de expansão burguesa e dissolução do latifúndio (associado ao feudalismo) não é, para Sodré, tão imediato como uma leitura simplista faz parecer. Tendo em vista que começara a preponderar a economia de mercado e que, no poder, não havia uma correspondência com essa nova realidade das forças produtivas, a situação era de 
instabilidade. ${ }^{68}$ Dessa forma, a Revolução de 1930 teria significado a dissolução da estrutura oligárquica, que, contudo, não desapareceu por completo do embate político e econômico entre os vitoriosos do movimento, encontravam-se duas correntes: a reformista (burguesa) e a conformista (latifundiária). A figura de Getúlio é diretamente associada à componente reformista da Revolução, que ganha espaço nos anos 1930, com a janela deixada pelo "recuo imperialista" da crise de 1929. A ala reformista, no entanto, não é vista como hegemônica no pós-1930: “A luta entre as facções vencedoras realmente prosseguiu, mais violenta e mais desencontrada, na fase posterior à vitória revolucionária". 69

Outra vertente, cujo pioneiro seria Virgínio Santa Rosa, associa 1930 à vitória das classes médias. Em seu estudo, escrito ainda sob o impacto da Revolução de 1930, Santa Rosa vê, como estruturante da sociedade brasileira, uma dicotomia ligeiramente distinta da aquela apresentada por Sodré: o Brasil seria cindido entre a burguesia, que se confundiria com a alta burguesia, possuidora dos latifúndios e do poder político, e pequena burguesia, por vezes confundida com o proletariado, "formada exclusivamente pelas classes médias das cidades, o operário das fábricas e os párias quase inconscientes dos campos". ${ }^{70}$ A partir da dissolução da aristocracia rural brasileira, que teria ocorrido com a desintegração da monarquia, a burguesia teria vivido um processo de ascensão contínua, ao longo da história republicana. O "progresso material" da nação só teria beneficiado a "alta burguesia", ligada ao latifúndio, mantendo alijada dos ganhos advindos da modernização a pequena burguesia, que crescera também, acompanhando o desenvolvimento da indústria e do comércio. É essa classe, detentora de interesses um tanto quanto difusos, que se teria insurgido na Revolução de 30. Os tenentes foram, para Santa Rosa, a primeira expressão política dessa pequena burguesia, ou da classe média, da qual eram oriundos. Os fatores que lhes deram condição de representar as classes médias foram sua própria consciência de classe e a experiência acumulada ao longo das revoltas dos anos 1920.

Também nessa linha, Guerreiro Ramos faz uma análise do período republicano a partir da participação da classe média brasileira no exercício do poder, entendendo essa classe como o conjunto dos pequenos negociantes e industriais, profissionais liberais, funcionários, militares e assalariados, que se diferenciavam da massa operária comum por sua qualificação e instrução. ${ }^{71}$ Com uma curta pausa "bonapartista", entre 1889 e 1894, em que a classe média

\footnotetext{
${ }^{68}$ SODRÉ, Nelson Werneck. História da burguesia brasileira. 3. ed. Rio de Janeiro: Civilização Brasileira, 1976 [1964]. p. 264. Para Sodré, a burguesia é a classe ligada exclusivamente ao setor industrial, não há uma "burguesia cafeeira" - esta classe, seria, por definição, associada ao latifúndio.

${ }^{69}$ SODRÉ, 1976, p. 279.

${ }^{70}$ SANTA ROSA, Virgínio. O sentido do tenentismo. 3. ed. São Paulo: Alfa-Ômega, 1976. [1933]. p. 27.

${ }^{71}$ GUERREIRO RAMOS, Alberto. A crise do poder no Brasil. Rio de Janeiro: Zahar, 1961. pp. 21-32.
} 
teria feito sua primeira incursão no centro do poder, pela via de uma aliança com o setor militar, o Brasil teria sido governado, de 1822 a 1930, pelo latifúndio e pelo alto comércio. O ímpeto reformista da classe média teria existido, de fato, na Primeira República, como atestam os episódios das rebeliões tenentistas (representantes do ideário pequeno-burguês) e da campanha civilista. Todavia, a política dos governadores, implantada por Campos Sales com um sentido restaurador da ordem latifundiária pré-republicana, teria logrado manter a classe média na periferia do poder até 1930. A Revolução de 30 daria a essa classe um lugar na esfera decisória do país: inaugurava-se assim o ciclo das lutas pela estruturação ideológica dos interesses de classe no Brasil. 1930 seria um marco, portanto, de mudança na composição da minoria dirigente, passando a fazer-se sentir "os reclamos do novo empresariado que a industrialização criou e do crescente assalariado de 'colarinho e gravata'. A classe operária, embora em ascensão política, é contida na periferia do poder."72

É um pouco diferente a interpretação de Francisco Weffort que, em estudo sobre o populismo $^{73}$, qualifica o papel tanto da burguesia industrial quanto dos grupos médios urbanos no episódio revolucionário de 1930, visto como um movimento liderado por homens de classe média e alguns oligarcas, que abriu a crise do sistema oligárquico estabelecido em 1889. A partir de 1930, teria havido uma ampliação institucional das bases sociais do Estado, com a participação crescente das classes médias e dos setores burgueses, vinculados à industrialização. A burguesia industrial teria sido um dos setores mais beneficiados pelo Estado que se instala a partir de 1930, mas seria ilusório supor que os industriais tiveram um papel dominante no movimento que destituiu as oligarquias do poder, pois a Aliança Liberal teria sido uma transação entre grupos oligárquicos dissidentes e alguns grupos médios urbanos. Aqui, Weffort concorda com Furtado e assume que a reorientação da economia brasileira para a indústria, posta em marcha na esteira da crise dos anos 1930, não teria sido resultado de uma política industrialista deliberada. As classes médias, por sua vez, exerceram importante pressão pela mudança de regime, ainda durante a Primeira República: eram, em sua maioria, funcionários públicos, militares e profissionais liberais os líderes dos movimentos antioligárquicos da década de 1920. Nesse quesito, o autor está na linha de Santa Rosa e Guerreiro Ramos ao perceber a Revolução de 1930 como ponto culminante dessas pressões dos grupos médios.

As classes médias, entretanto, não possuíam "vocação para o poder": socialmente dependentes de uma estrutura em que a grande propriedade ainda era o padrão econômico

\footnotetext{
${ }^{72}$ GUERREIRO RAMOS, 1961, p. 32.

${ }^{73}$ WEFFORT, Francisco. “O populismo na política brasileira”. IN: FURTADO, Celso (org.). Brasil: tempos modernos. 2. ed. Rio de Janeiro: Paz e Terra, 1977. pp. 52-64.
} 
dominante, essa classe não forma uma ideologia própria, isto é, um programa de transformação social original. "Nessas condições, o novo Governo terá que mover-se sempre dentro de uma complicada faixa de compromissos e conciliações entre interesses diferentes e por vezes contraditórios". ${ }^{74}$ Nesse vácuo de hegemonia, o Estado adquire uma imagem de soberania sobre o conjunto da sociedade, com um poder personalista e com a necessária participação das massas urbanas. Esse Estado, que é burguês, mas não se enquadra no conceito tradicional europeu, é um "Estado de compromisso": expressão da crise agrária, das pressões populares e da dependência socioeconômica das classes médias e da burguesia industrial.

Essa ideia do Estado de compromisso é adotada por Boris Fausto, que mostrou, com base em pesquisa histórica mais aprofundada, que a Revolução de 1930 foi um movimento que não era expressão direta nem da burguesia industrial, nem das classes médias. Para Fausto, a liderança do movimento coube a uma frente difusa, com apoio das classes médias, do setor militar e de certas classes dominantes regionais. Com a vitória da Revolução e a quebra da institucionalidade da República Velha, abriu-se um vazio de poder, dando lugar ao Estado de compromisso. ${ }^{75}$ A ideia de compromisso e de vácuo de hegemonia se sustenta: não deve obscurecer, todavia, um aspecto relevante. Por mais que não tenha sido instituído e sustentado por uma classe específica, é no âmbito deste Estado que se abriu a possibilidade histórica concreta do desenvolvimento industrial fomentado pelo setor público no Brasil. O desenvolvimento industrial esteve ligado ao fortalecimento político da burguesia industrial, da qual Simonsen foi representante, mas esse processo não foi automático. A construção da hegemonia desta classe, nos termos de Gramsci, se deu por meio da reafirmação gradual de seus interesses no âmbito desse Estado de compromisso.

De toda maneira, essa possibilidade histórica da industrialização com o apoio do Estado não se colocou de forma imediata com a Revolução de 1930, nem estava contida em seu ideário. Houve, ao longo dos anos 1930 e 1940, um processo de industrialização concomitante com a criação de instituições estatais voltadas para o planejamento e o fomento à atividade econômica: um processo não determina o outro de forma unívoca. No percurso político da Era Vargas, o Estado Novo, instituído em 1937, foi uma inflexão importante, que teve impacto sobre a trajetória de Simonsen: com sua implantação e a criação de vários Conselhos Técnicos, Simonsen passou a atuar diretamente na esfera pública de forma mais direta, e em nível federal, isto é, galgou postos de maior influência no debate de ideias econômicas e na formulação de política econômica. Para dar sentido histórico a essa trajetória de Simonsen,

\footnotetext{
${ }^{74}$ WEFFORT, 1977, p. 61.

${ }^{75}$ FAUSTO, [1969] 1997, pp. 136-144.
} 
convém perguntar sobre os condicionantes que a determinaram: como era este Estado que abriu as portas para sua participação política mais efetiva? Um fator importante a se discutir é a natureza dos projetos políticos do governo Vargas, da Revolução de 1930 ao Estado Novo. Como pretendemos mostrar - e os postos ocupados por Simonsen já sinalizam isso - com o Estado Novo se solidificou, no âmbito do Estado, um projeto político mais nacionalista e ideologicamente mais próximo daquilo que Bielschowsky identificou como ideologia desenvolvimentista.

As propostas contidas na Plataforma da Aliança Liberal, de fato, não eram de cunho industrialista: os setores primários eram os mais destacados, merecendo especial atenção o café. A Plataforma chegava a criticar os programas de valorização então em curso, sugerindo uma diminuição do grau de envolvimento do Estado com o setor cafeicultor. Basta lembrar que a própria Aliança Liberal não era uma candidatura avessa ao regime da Primeira República: o que houve de novidade foi um alinhamento de oligarquias dissidentes - Rio Grande do Sul e estados menores do Norte e Nordeste - com Minas Gerais, em torno do nome de Getúlio. Tratava-se, como visto acima, de um movimento apoiado por grupos médios e por militares, mas liderado por políticos ligados aos setores primários, dos quais a economia brasileira dependia fundamentalmente, ainda que, já houvesse um processo de diversificação econômica em marcha na década de $1920 .^{76}$

Se não era a ênfase da Plataforma da Aliança Liberal, a indústria também não foi esquecida. Uma menção, em especial, é digna de destaque, por representar uma mudança no tipo de industrialização que um governo, ao menos no plano das intenções, projetava para o Brasil: propunha-se a fabricação de munição e vasos de guerra, ainda que de pequena tonelagem, numa clara tentativa de ganhar a simpatia dos militares. ${ }^{77}$ Tal proposta pressupunha o encaminhamento da questão siderúrgica, fundamental para a indústria de base, o que significa uma mudança qualitativa na direção da ideia de construção de um parque industrial diversificado. O encaminhamento dado pelo governo Vargas, em seus anos iniciais, à questão siderúrgica é um exemplo de ambiguidade entre intenção e colocação em prática de uma política econômica. Em conhecido discurso, proferido em Belo Horizonte, no dia 23 de fevereiro de 1931, Vargas destacou a siderurgia como prioridade máxima do governo revolucionário.

Mas o problema máximo, pode dizer-se, básico da nossa economia, é o siderúrgico. Para o Brasil, a idade do ferro marcará o período da sua opulência econômica. No amplo emprêgo dêsse metal, sôbre todos precioso, se expressa a equação do nosso progresso. (...) Creio poder, portanto, afirmar que a grandeza futura do Brasil

\footnotetext{
${ }^{76}$ FONSECA, Pedro Cezar Dutra. Vargas: o capitalismo em construção. Rio de Janeiro: Brasiliense, 1987. pp. 118-120.

${ }^{77}$ FONSECA, 1987, pp. 121-122.
} 
depende, principalmente, da exploração das suas jazidas de ferro. E o ferro é Minas Gerais. $^{78}$

Em que pese a ênfase dada e o reconhecimento, por parte da historiografia, de que o discurso é uma manifestação clara das intenções desenvolvimentistas de Getúlio, tal ponto tem sido matizado por uma leitura que contrasta o discurso com as medidas de fato tomadas durante os governos provisório e constitucional de Vargas (1930-37). ${ }^{79}$ O sentido da política siderúrgica teria sido a separação dos problemas da exploração do minério de ferro e de produção de aço, com a priorização da atividade extrativa. Essa separação tem um sentido importante no debate siderúrgico, pois a reivindicação histórica era que empresas mineradoras vinculassem a extração de minério ao compromisso de beneficiar ao menos uma parte dele em território nacional, favorecendo a instalação da indústria siderúrgica no Brasil. A posição do governo federal, como mostra Gustavo Barros, era a de manter a exploração de minério a cargo da Itabira Iron e a siderurgia a cargo da Belgo-Mineira. Essa posição era a mesma do governo mineiro, com o qual Vargas tinha de cultivar uma aliança estável neste período pósrevolução, já que, como vimos, tratou-se de um movimento capitaneado por oligarquias dissidentes. A referência a Minas Gerias neste discurso, proferido em Belo Horizonte, não é casual. Neste caso, trata-se de um encaminhamento basicamente político de uma questão relativa à siderurgia: isso não significa que não tenham sido tomadas medidas, como a criação da Comissão Nacional de Siderurgia e a construção de um ramal ferroviário que favorecia a Usina Belgo-Mineira, mas os determinantes da política siderúrgica, neste primeiro momento, parecem ser mais ligados à afirmação política do governo do que a um plano de desenvolvimento econômico. A questão siderúrgica passou a receber um tratamento mais enfaticamente intervencionista no Estado Novo, já sem o vínculo a Minas Gerais e de forma articulada à oportunidade engendrada pelo contexto da Segunda Guerra. Neste momento, já havia uma consciência clara de que o Estado deveria assumir para si a instalação da grande siderurgia e o problema, antes vinculado a Minas Gerais, ganha caráter nacional.

Embora tentasse dar um sentido inovador a suas propostas neste início de governo, Getúlio Vargas tinha de lidar com o fato de que a cafeicultura ainda era a principal atividade econômica do país. Sobre a política cafeeira de Vargas, a interpretação clássica é a apresentada por Celso Furtado. Para Furtado, a indústria teria sido favorecida pela compra e eliminação de estoques de café, na medida em que, ao adquirir o café invendável, o governo mantinha a renda nacional em patamares mais elevados do que teria sido possível sem a

\footnotetext{
${ }^{78}$ VARGAS, Getúlio. A nova política do Brasil. I. Da Aliança Liberal às realizações do $1^{\circ}$ ano de governo. Rio de Janeiro: Livraria José Olympio Editora, 1938.

${ }^{79}$ BARROS, Gustavo. "Discurso e contexto: política siderúrgica no primeiro governo Vargas (1930-1937)”. Texto de discussão apresentado no Seminário Hermes \& Clio. São Paulo: FEA/USP, 2012.
} 
intervenção, num contexto em que o Brasil não possuía divisas suficientes para fazer frente às suas necessidades de importação. Isso criava uma proteção à indústria doméstica instalada, que passava a substituir importações de bens manufaturados de consumo, sobretudo pela utilização da capacidade ociosa. ${ }^{80}$ Vale lembrar que, para Furtado, esse mecanismo funcionou devido à existência de um fluxo de renda, que, com o advento do trabalho assalariado, fazia com que a criação de renda proporcionada pela compra de estoques de café representasse, para o conjunto da economia, um aumento da renda nacional incompatível com a capacidade para importar, o que estimulou a substituição de importações. ${ }^{81}$ Se via a política cafeeira do governo Vargas como variável fundamental a explicar o deslocamento do eixo dinâmico da economia brasileira nos anos 1930, Furtado não considera tais medidas como de cunho intencionalmente industrializante.

O debate sobre a intencionalidade não só da política cafeeira, mas da política econômica dos primeiros anos de Vargas, iniciara-se já com Roberto Simonsen, que diz, em 1939, sobre a evolução industrial recente do Brasil: "É um progresso industrial, em sua maior parte alheio à ação dos governos e às questões de política interna, gerado por um determinismo econômico inelutável." ${ }^{, 82}$ Para Celso Furtado, como foi referido, o desenvolvimento industrial não foi alheio à atuação do governo, cuja política cafeeira teria contribuído para manter o dinamismo interno num contexto de crise, mas esta atuação não era intencional: "Praticou-se no Brasil, inconscientemente, uma política anticíclica de maior amplitude que a que se tenha sequer preconizado em qualquer dos países industrializados". 83

Pedro Dutra Fonseca retomou essa discussão, ao contestar a ideia furtadiana da industrialização inconsciente por meio da apresentação de evidências da consciência industrializante do governo Vargas. ${ }^{84}$ Tais evidências, se robustas para o período do Estado Novo, são fracas para o início do governo Vargas. O autor elenca como evidências dessa consciência, ainda antes de 1937, o Tratado de 1935, a Reforma Tarifária de 1934, os discursos de Vargas e as diversas instituições criadas pelo governo. Com exceção da Tarifa de 1934, as outras duas evidências são pontos polêmicos na historiografia.

\footnotetext{
${ }^{80}$ FURTADO, Celso. Formação econômica do Brasil. [1959]. 34 ed. São Paulo: Companhia das Letras, 2007.

${ }^{81}$ Esta interpretação de Furtado foi duramente criticada por Carlos Manuel Peláez. Segundo este autor, as compras de café teriam sido financiadas via imposto sobre a exportação, o que anularia os efeitos multiplicadores sobre a renda referidos por Furtado. Ademais, a prolongada intervenção no mercado, por parte do governo, teria prejudicado o desenvolvimento da indústria no Brasil, ao distorcer as rentabilidades relativas dos setores industrial e agrícola da economia. Ver PELÁEZ, Carlos Manuel. História da industrialização brasileira. Rio de Janeiro: APEC, 1972. Para uma síntese deste debate, que gerou outras contribuições importantes, ver SUZIGAN, Wilson. Indústria brasileira: origem e desenvolvimento. São Paulo: Hucitec, 2000. pp. 30-47.

${ }^{82}$ SIMONSEN, Roberto. A evolução industrial do Brasil. São Paulo: FIESP, 1939. p. 29.

${ }^{83}$ FURTADO, [1959] 2007, p. 272

${ }^{84}$ FONSECA, Pedro Cezar Dutra. "Sobre a intencionalidade da Política Industrializante do Brasil na Década de 1930". IN: Revista de Economia Política, v. 23, n.1(89), jan-mar/2003. pp. 133-148.
} 
Como já foi dito no caso da siderurgia, nem sempre houve uma correspondência clara entre o discurso de Vargas e a adesão e colocação em prática de um projeto claro de desenvolvimento da indústria siderúrgica: além do exemplo da siderurgia, pode-se citar o do setor de energia elétrica. Uma medida muitas vezes citada como desenvolvimentista é o Código de Águas (1934) que, ao eliminar a propriedade privada de cursos e quedas d'água, estabelecia que as tarifas deveriam ser cobradas, pelas empresas fornecedoras de energia elétrica (ligadas ao capital estrangeiro), com base no "custo do serviço" prestado, mantendo uma taxa de lucro "justa" e evitando cobranças abusivas. No entanto, o Código só foi regulamentado por lei em $1950^{85}$. Embora, no plano do discurso, reconhecesse por meio da promulgação do Código, a importância de uma política energética que resguardasse os interesses nacionais e promovesse o desenvolvimento industrial, o governo Vargas não avançou significativamente na questão da energia elétrica. Pedro Paulo Bastos aponta como principal crítica ao primeiro governo Vargas o fato de ter-se limitado a uma declaração de princípios, sem avançar nem no plano da regulação, fiscalizando a rentabilidade das empresas, nem no da expansão da oferta, criando possíveis mecanismos de financiamento que garantissem energia abundante a preços baratos. Para o autor, a atuação mais incisiva, por parte de Vargas, no setor elétrico se dará somente em seu segundo governo. ${ }^{86}$ Por meio dos casos da siderurgia e da eletricidade, fica claro que não é possível depreender um projeto industrializante efetivo a partir dos discursos e declarações de princípios do início do governo Vargas.

Quanto ao Tratado de 1935, a posição dos industriais na Câmara dos Deputados, quando dos debates em torno da ratificação do tratado, é enfática e contrária ao acordo. Simonsen, em discurso proferido em 11 de novembro de 1935, na qualidade de deputado classista, afirmava: "asignámos um tratado em que prevaleceram as directrizes da politica norte-americana". ${ }^{87} \mathrm{De}$ fato, prevaleciam os interesses norte-americanos no tratado, devido à cláusula de nação mais favorecida concedida aos EUA pelo Brasil. Ainda que incluísse a redução de tarifas para produtos possivelmente ligados à intensificação do desenvolvimento industrial no Brasil, tais como máquinas agrícolas, autopeças, automóveis, etc., torna-se difícil entender a assinatura do Tratado de 1935 como uma medida de fomento à industrialização, por parte do governo Vargas, quando se leva em conta que a iniciativa de firmar o acordo foi tomada unilateralmente pelos Estados Unidos. Essa discussão será retomada mais adiante, quando

\footnotetext{
${ }^{85}$ BASTOS, Pedro Paulo Zahluth. "O projeto nacionalista de Vargas". IN: BASTOS, Pedro Paulo Zahluth e FONSECA, Pedro Cezar Dutra. (orgs.) A Era Vargas: desenvolvimentismo, economia e sociedade. São Paulo: Editora da Unesp. p. 277.

${ }^{86}$ BASTOS, 2012, pp. 280-292.

${ }^{87}$ Anais da Câmara dos Deputados, v. XV (11/05/1935), p. 291.
} 
tratarmos da participação de Simonsen nos debates sobre o Tratado de 1935.

A tarifa de 1934, que pôs fim à cobrança da quota-ouro e estabeleceu taxas específicas fixas sobre as mercadorias importadas, é um argumento mais condizente com um projeto industrialista no primeiro governo Vargas. Associada a essa medida, há que lembrar a criação da Comissão de Similares, que deveria conceder o registro de similar ao produto nacional que estivesse em condição de substituir o artigo importado. ${ }^{88}$

Outro argumento válido, em favor da intencionalidade da política industrializante de Vargas, é a criação de um aparato administrativo que possibilitou a formulação e aplicação de políticas estatais de fomento ao desenvolvimento industrial. Tais instituições, todavia, foram, em sua maioria, criadas no período do Estado Novo. Com exceção do Conselho Federal de Comércio Exterior, de 1934, a maioria dos órgãos que dizem respeito à indústria ou à "agroindústria" foi fruto da centralização política da ditadura Vargas. Como exemplos, vale mencionar: Departamento Administrativo do Serviço Público (DASP) e Instituto Brasileiro de Geografia e Estatística (1938); Plano de Obras Públicas e Aparelhamento de Defesa (1939); Fábrica Nacional de Motores (1940); Companhia Siderúrgica Nacional e Comissão de Combustíveis e Lubrificantes (1941); Companhia Vale do Rio Doce e Banco de Crédito da Borracha (1942); Companhia Nacional de Álcalis, Comissão de Financiamento da Produção e Coordenação de Mobilização Econômica (1943); Conselho Nacional de Política Industrial e Comercial (CNPIC) e Comissão de Planejamento Econômico (1944). A esses órgãos acrescentem-se os Institutos Nacionais do Pinho, do Sal e do Mate, também criados no Estado Novo. Por fim, vale citar a Superintendência de Moeda e Crédito (SUMOC), de 1945, que desempenharia funções de banco central, controlando a política monetária e cambial. Do ponto de vista da criação de novas instituições, o Estado Novo significou uma ruptura no sentido do planejamento econômico e do fomento à produção industrial.

No que se refere ao uso das reservas cambiais e ao pagamento da dívida pública, o Estado Novo também significou uma inflexão significativa. Com o golpe, em 1937, foi suspenso o pagamento do serviço da dívida externa, retomado a partir dos acordos de 1940 e 1943 . Ao suspender o pagamento da dívida e colocar a questão em termos de "ou pagamos a dívida, ou reequipamos as forças armadas", Vargas cortejava a opinião pública e seus grupos de sustentação política. Dada a rigidez da pauta de importações, a suspensão do pagamento do serviço da dívida permitia o aumento da importação de insumos considerados essenciais e mesmo de bens de consumo conspícuo, o que seria bem recebido por setores industriais e pelas classes médias urbanas. Marcelo de Paiva Abreu identifica, com o Estado Novo, uma

\footnotetext{
${ }^{88}$ LEOPOLDI, 2000, pp. 116 e 118.
} 
reversão da tendência de "generosidade" brasileira com os empréstimos estrangeiros, presente nos acordos de pagamento da dívida firmados anteriormente, em 1931 e $1934{ }^{89}$

A eclosão da Segunda Guerra resultou na perda dos mercados de exportação brasileiros na Europa ocidental, agora ocupada pelo Eixo, perda esta não compensada, pelo menos antes de 1941-42, pelo aumento das exportações aos aliados e neutros. A situação mudou com a combinação de acordos estratégicos de fornecimento aos aliados e de uma maior demanda por produtos brasileiros em mercados antes supridos por Reino Unido e EUA, que restringiam exportações devido ao esforço de guerra. A escassez crônica de importações, combinada com os estímulos mencionados, gerou uma melhora no saldo comercial brasileiro. Se, por um lado, a restrição às importações poderia fomentar o desenvolvimento de setores produtores de bens sem alternativa de fornecimento externo, a dificuldade de obtenção de certos insumos emperraria o crescimento industrial. Concretamente, viu-se nesse período um incremento da taxa de crescimento da produção industrial doméstica brasileira, após um breve ajustamento. ${ }^{90}$ Há um contraste entre a política inicial, de buscar compromissos com os credores internacionais, concretizada por meio dos funding loans de 1931 e de 1934, e a moratória da dívida externa em 1937. As estimativas apontam que esta interrupção no pagamento permitiu que o Brasil reduzisse os dispêndios com a dívida externa a um nível inferior à sua capacidade de pagamento, numa clara inversão de prioridades no uso das reservas cambiais. ${ }^{91}$

$\mathrm{Na}$ Constituição de 1937, foi incluído o princípio da nacionalização de novas licenças para bancos e companhias de seguro, medida que foi regulamentada em 1941. Pouco antes do golpe, em outubro de 1937, fora criada a Carteira de Crédito Agrícola e Industrial (CREAI) do Banco do Brasil, visando a contornar a carência de financiamento de longo prazo no setor bancário privado brasileiro. Medidas como a moratória da dívida, a criação da CREAI e o princípio de nacionalização das instituições financeiras demonstram que se consolidara a percepção, por parte do governo, de que o Brasil não poderia contar somente com influxos privados de recursos para financiar o seu crescimento econômico. Seria necessário fortalecer os mecanismos de obtenção de capitais locais e os fundos estatais. Nesse sentido, pode-se afirmar, com Pedro Paulo Bastos, que o Estado Novo trouxe, na política de crédito e pagamento da dívida, uma inflexão nacionalista-desenvolvimentista. ${ }^{92}$

\footnotetext{
${ }^{89}$ ABREU, Marcelo de Paiva. "Crise, crescimento e modernização autoritária: 1930-1945”. IN: ABREU, Marcelo de Paiva (org.). Ordem do progresso; cem anos de política econômica republicana 1889-1989. Rio de janeiro: Elsevier, 1990. p. 100.

${ }^{90}$ Segundo dados de Marcelo de Paiva Abreu, em 1939-42, a taxa de crescimento do produto industrial foi de 1,6\%; entre 1939 e 1945, foi de 9,9\%. Ver ABREU, 1990, p. 94.

${ }^{91}$ BASTOS, 2012.p. 265.

${ }^{92}$ BASTOS, 2012,. pp. 267-269.
} 
Foi no Estado Novo que o Estado brasileiro surgiu de fato como empresário da indústria de base, por meio da Companhia Siderúrgica Nacional, constituída em 1941, responsável pela Usina de Volta Redonda, da Companhia Vale do Rio Doce (1942), da Fábrica Nacional de Motores (1940) e da Fábrica Nacional de Álcalis (1943). Vale ressaltar a importância da Segunda Guerra Mundial: durante o período, o Estado Novo se caracterizou, de forma clara, como impulsionador do desenvolvimento industrial. A situação de guerra fazia com que fosse necessário fomentar a atividade econômica de forma mais coordenada e planejada. ${ }^{93}$

No Estado Novo, consolidou-se um projeto industrialista, ou ligado à ideologia desenvolvimentista. Francisco Iglésias resume esta ideia ao afirmar que é no Estado Novo que se confirma a superação da ideologia liberal pela intervencionista, protecionista, nacionalista. “O Estado Novo tornou conhecidas e frequentes palavras como 'plano', 'planejamento', 'planificação'." Se já havia órgãos estatais voltados para o planejamento antes de 1937, o novo regime aumentou-lhes o número, dando mais funcionalidade à máquina administrativa. ${ }^{94}$ Em suma, depreende-se, dos parágrafos anteriores que o Estado varguista assumiu um projeto industrialista, que terá orientação ideológica mais clara e resultará em realizações concretas, a partir de novembro de 1937, com a instituição do regime do Estado Novo. Diversos fatores contribuíram para isso. Um dado importante é o aprofundamento das tensões internacionais, que levou à Segunda Guerra, tornando indispensável ao Brasil promover algum tipo de coordenação das suas atividades econômicas, para lidar com as restrições que a guerra impunha. Não só as restrições, mas as oportunidades abertas pela guerra também contribuíram para que o Estado assumisse um papel destacado: o caso da siderurgia é exemplar. Ademais, o próprio caráter ditatorial do regime facilitava a criação de órgãos executivos e empresas estatais.

Para além do planejamento econômico e da formulação de políticas de fomento ao desenvolvimento industrial, os órgãos e Conselhos Técnicos criados no Estado Novo operaram uma mudança na estrutura de poder. O eixo de representação da sociedade civil, num regime que fechara o Congresso, deslocara-se para os órgãos e conselhos técnicos. Tratava-se, é claro, de uma representação antidemocrática, ligada às concepções autoritárias que viam a política de forma elitista, valorizando o aspecto técnico, em detrimento da incorporação das camadas populares ao processo político. Tal representação garantia a possibilidade de que os interesses industriais se expressassem sem a mediação políticoeleitoral. Na referida situação de "compromisso", em que não havia exatamente uma

\footnotetext{
${ }^{93}$ GORENDER, Jacob. “A participação do Brasil na Segunda Guerra Mundial e suas consequências”. IN: SZMRECSÁNYI, Tamás e GRANZIERA, Rui G. (org.). Getúlio Vargas e a economia contemporânea. 2. ed. São Paulo: Hucitec, 2004.

${ }^{94}$ IGLÉSIAS, Francisco. "Aspectos políticos e econômicos do Estado Novo". IN: SZMRECSÁNYI e GRANZIERA, 2004.
} 
hegemonia da burguesia industrial, a forma democrática da política podia representar ameaça aos interesses dessa classe em ascensão. Não por acaso, um dos principais argumentos para a legitimação da ditadura de Vargas foi o perigo comunista. Nos termos colocados por Eli Diniz, os Conselhos Técnicos evitavam mediações: a indústria estava representada dentro do Estado, no âmbito do poder executivo. ${ }^{95}$

É nesse contexto que Simonsen foi chamado a integrar o já citado Conselho Nacional de Política Industrial e Comercial (CNPIC), na qualidade de representante de um projeto de desenvolvimento de uma classe específica, que encontrava representatividade direta no âmbito do Estado, por meio do arranjo institucional do Estado Novo. Ao adotar esse arranjo institucional específico, estruturado em torno dos Conselhos Técnicos que permitiam uma representação direta da burguesia industrial, o Estado assumia o projeto industrialista de forma mais clara. Simonsen, que era um reconhecido porta-voz dos interesses industriais, participou ativamente dessa nova estrutura de poder.

Inicialmente ligado um projeto de modernização, isto é, de transformação muito restrita do Brasil, Simonsen foi inicialmente um opositor do governo Vargas. Subindo ao poder a partir de uma situação de compromisso político, tal governo não tinha um projeto que expressava os interesses de uma classe específica. Como vimos, no entanto, ao longo dos anos 1930, e sobretudo no período do Estado Novo, o governo criou órgãos e tomou medidas de política econômica que aproximaram da ideologia desenvolvimentista, nos termos colocados por Bielschowksy. Entre essas instituições criadas, de fomento à atividade econômica e planejamento, estavam os Conselhos Técnicos, que permitiram uma representação direta da burguesia industrial, uma classe em processo de afirmação hegemônica, no âmbito do Executivo. A mudança de posição política de Simonsen, que apoiou o golpe de 1937, de alguma forma coincide com sua participação mais direta nessa estrutura de poder: fez parte do Conselho Federal de Comércio Exterior, em 1937; da Coordenação de Mobilização Econômica, durante a Segunda Guerra; e do Conselho Nacional de Política Industrial e Comercial, em 1944-45. Esse percurso de Simonsen - da lógica da modernização, no sentido furtadiano, a uma atuação política voltada para a proposição de políticas econômicas de abrangência nacional - é reconhecível em sua produção intelectual, ligada à história e aos temas mais estritamente econômicos: é sobre essas elaborações que versam os capítulos seguintes.

${ }^{95}$ DINIZ, 1978, p. 79 e pp. 106-107. 


\section{Capítulo 2. Nacionalismo, industrialismo e história}

Neste capítulo propõe-se analisar os textos daquela que se poderia chamar a fase de “formação intelectual" de Simonsen e, a partir disso, reconstruir a interpretação dada pelo autor para a história do Brasil. Os textos iniciais, das décadas de 1910 e 1920, estão reunidos na coletânea, publicada por Simonsen em janeiro 1932, intitulada À margem da profissão, que reunia seus textos desde os anos 1910 até o texto "As finanças e a indústria - Conferência no Mackenzie College", de 1931. Essa publicação foi, em conjunto com o livro A construção de quartéis para o exército (1931), uma tentativa de dar uma resposta à opinião pública sobre os questionamentos feitos a respeito das obras executadas pela Companhia Construtora de Santos. Outros textos analisados neste capítulo, que permitem reconstruir a interpretação de Simonsen da história do Brasil, são: o opúsculo As crises no Brasil (1930), além de História econômica do Brasil (1937), Aspectos da história econômica do café (1938), Evolução industrial do Brasil (1939) e "Recursos econômicos e movimentos das populações" (1940). Há aí um salto cronológico: de 1930 para 1937. Alguns dos textos escritos nesse período, bem como os registros da participação parlamentar de Simonsen, serão estudados em separado no capítulo seguinte.

Dois eixos estão presentes nos textos de Simonsen, sobretudo a partir de finais dos anos 1920: o primeiro é mostrar que os interesses da indústria equivalem aos interesses da nação. Isso já aparece com força no discurso “Orientação Industrial Brasileira”, de 1928, que marca a fundação do CIESP (Centro das Indústrias do Estado de São Paulo), decorrente da cisão dos industriais paulistas com relação à Associação Comercial de São Paulo. O segundo eixo é interpretar a economia brasileira e sua formação histórica a partir desse nacionalismo industrialista. Esse tipo de interpretação orientou a aplicação, para a história do Brasil, da abordagem dos ciclos, utilizada previamente para o caso português por João Lúcio de Azevedo.

Vale notar que aquilo que está implícito na abordagem dos ciclos é coerente com o projeto nacionalista-industrialista de Simonsen e lança bases para interpretações posteriores: a ideia de que a economia colonial era dominada por fases de expansão pronunciada da riqueza, seguidas por momentos de dilapidação rápida da mesma implica que a economia de bases coloniais nada legava de permanente à nação. Somente a industrialização poderia de fato possibilitar a "evolução progressista" do Brasil, por legar ao país uma riqueza permanente. Portanto, se, por um lado, é esquemática e alvo de críticas por parte de historiadores posteriores, a interpretação de Simonsen não é incoerente com seu projeto intelectual e suas implicações têm profunda importância para as discussões posteriores acerca da nossa história 
econômica. ${ }^{96}$

O nacionalismo de Simonsen está referido numa perspectiva de consolidação da hegemonia burguesa no Brasil: Roberto Simonsen poderia ser considerado um intelectual orgânico, nesse processo de construção hegemônica, no sentido dado por Gramsci. O momento-chave do estabelecimento da hegemonia de uma classe social sobre as demais é quando a ideologia de uma classe específica supera os limites dessa classe, passando a prevalecer sobre as outras, constituindo-se na ideologia do Estado-governo. As classes subordinadas passam a perceber tal ideologia como sua própria. Um intelectual, nessa perspectiva, tem função organizativa: estabelecer um consenso em torno do prestígio e dos projetos da classe dominante - no caso, a burguesia industrial - e mecanismos de coerção para aqueles grupos que não consintam com a hegemonia estabelecida. A associação entre interesses da indústria e interesses da nação, feita por Simonsen, e a própria interpretação da história que daí decorre podem ser vistos sob a ótica da construção de uma hegemonia industrial-burguesa no Brasil. ${ }^{97}$

Do ponto de vista da história do pensamento social brasileiro, esse nacionalismo industrialista de Simonsen parece relacionado a um tipo de pensamento, formado ao longo da Primeira República, classificado por alguns autores como nacionalista autoritário. Esse pensamento se teria formado a partir de uma "ideologia de Estado", no sentido dado por Bolívar Lamounier: a condensação de um clima de ideias e de aspirações políticas no final do século XIX e início do XX que se conformou numa reação filosófica ao iluminismo e ao utilitarismo. É uma visão do mundo na qual são afastadas as representações relacionadas à ideia de "mercado político", que era a imagem central e integradora no modelo liberal clássico. Na visão liberal, o próprio Estado é teorizado em função do mercado. No modelo da ideologia de Estado, ao contrário, o fulcro é o intento de domesticar o mercado, pela via do Estado. ${ }^{98}$

Nenhum autor considera Simonsen exatamente um membro desse grupo nacionalista autoritário, que inclui Oliveira Viana, Azevedo Amaral e Francisco Campos, mas algumas afinidades entre as ideias desses pensadores e as de Simonsen merecem ser mencionadas, sobretudo aquelas relacionadas à visão do processo histórico. Nas décadas de 1920 e 1930, até a implantação do Estado Novo, havia um cenário de fermentação ideológica, no qual se sentia que o projeto político da Primeira República estava se esgotando. A Grande Depressão

\footnotetext{
${ }^{96}$ Sobre essa questão e sobre as afinidades entre Roberto Simonsen e Celso Furtado, no que se refere à interpretação da história econômica do Brasil, ver SAES, 2009.

${ }^{97}$ GRAMSCI, Antonio. Cuadernos de la cárcel. Tomo II. Caderno 4. 2. ed. México, D.F.: Ediciones Era, 1999. pp. 168-170ep. 188.

${ }^{98}$ LAMOUNIER, Bolívar. 'Formação de um pensamento autoritário na Primeira República, uma interpretação'. IN: História geral da civilização brasileira, tomo 3, volume2. São Paulo: Difel, 1977.p. 357.
} 
e, no plano interno, a Revolução de 1930 deram aos intelectuais a sensação de que era necessário “explicar o Brasil”. Oliveira Viana e Azevedo Amaral abandonaram a descrição, a história política, para fazer uma leitura histórica mais estrutural, com auxílio de outras ciências, como a geografia, a antropologia, a psicologia, a "ciência das raças". 99

Em sua leitura do processo histórico brasileiro, Oliveira Viana valorizava as mudanças evolutivas e as instituições que promoviam o equilíbrio na cúpula do poder. Viana ressaltou o significado do período colonial para a compreensão do Brasil e, destacando fatores mesológicos (extensão territorial e carência de vias), via a América portuguesa como carente de instituições sólidas e abrangentes, nos planos social e político. $\mathrm{O}$ resultado disso seria o isolamento das populações e supremacia da vida privada cujo centro era o clã rural patriarcal. Sua visão da Colônia, entretanto, não era totalmente negativa. Via o clã familiar como uma forma de solidariedade, centrada nos valores tradicionais. Elogiava o período monárquico, visto como responsável por assegurar a unidade do país, por meio da centralização do poder. A República teria vindo, com o federalismo, arrasar a obra ainda inconclusa da construção nacional. Os princípios da representação parlamentar, da soberania popular e do abolicionismo eram vistos como imposições do racionalismo dos liberais.

Azevedo Amaral tinha uma leitura um pouco distinta do passado brasileiro. Com inspiração biológica, sustentava a predominância, nas sociedades, dos instintos militar, econômico e político. No Brasil, prevaleceria o "Estado econômico", devido à colonização mercantilista portuguesa. Amaral, no entanto, não valorizava a colonização portuguesa, considerando-a responsável pelos entraves impostos ao progresso econômico da Colônia. A Monarquia também era vista de forma negativa. O Estado, embora estivesse no centro da nacionalidade nos anos 1930, não era, para o autor, um ente a-histórico: era visto, nos períodos colonial e monárquico, como condensação das tendências retrógradas e do parasitismo social. Um momento constituía exceção: a época mineradora, que possibilitara a criação de riquezas e esboçara o surgimento de uma consciência nacional.

A leitura de que a Colônia e o Império não foram exatamente benéficos é retomada por Simonsen a partir da perspectiva protecionista e industrialista, que via uma impossibilidade de auferir riquezas perenes da exportação de produtos primários e uma desorganização quase absoluta no que se referia à política tarifária e econômica de forma geral. A abordagem dos ciclos, que enfatiza o caráter efêmero da riqueza produzida pela exportação dos produtos-reis, também assume uma postura crítica diante do passado colonial.

Além disso, Simonsen - e também Celso Furtado - têm uma leitura diferenciada, à

\footnotetext{
${ }^{99}$ FAUSTO, Boris. O pensamento nacionalista autoritário. Rio de Janeiro: Jorge Zahar Ed., 2001. pp. 30-36. A discussão dos parágrafos seguintes se baseia nesta síntese de Boris Fausto.
} 
semelhança da de Azevedo Amaral, da economia mineradora: embora tenha sido uma economia colonial, suas potencialidades e suas contribuições, do ponto de vista da articulação de zonas antes desconexas e da formação de um mercado interno, foram maiores do que as da economia açucareira. ${ }^{100}$ Uma discussão mais aprofundada das relações entre o nacionalismo autoritário da Primeira República e o nacionalismo de Simonsen passaria por uma análise mais abrangente da produção intelectual, ligada ao autoritarismo, na Primeira República, o que foge ao escopo deste trabalho.

Destacam-se, neste capítulo, dois movimentos, inter-relacionados, no pensamento de Roberto Simonsen. O primeiro é a passagem de uma perspectiva mais centrada nas preocupações com a unidade produtiva privada ligada para uma perspectiva mais abrangente, vinculada aos problemas de âmbito nacional. Os primeiros textos publicados de Simonsen, possivelmente inspirados por sua formação em engenharia civil na Politécnica de São Paulo, referem-se a questões de organização e racionalização produtiva e inserem-se numa perspectiva de modernização do Brasil. Assuntos como política econômica, evolução histórica das atividades econômicas do Brasil, dentre outros de abrangência maior, vão aparecendo ao longo do tempo, principalmente a partir dos anos finais da década de 1920. O segundo movimento é a construção da referida interpretação da história do Brasil, baseada num nacionalismo vinculado ao projeto de classe dos industriais.

No esforço de buscar compreender as sintonias internacionais de Simonsen, destacam-se dois autores francófonos, referidos no texto As crises no Brasil, onde há alguma discussão mais teórica sobre crise e moeda: Maurice Ansiaux, belga, e Albert Aftalion, francês. A análise da apropriação de Simonsen desses autores aponta mais para um hibridismo de referências teóricas do que para a filiação a alguma escola de pensamento específica, como ficará claro a partir da análise dos cruzamentos entre esses autores.

\subsection{O início da carreira de Simonsen: da Escola Politécnica à FIESP}

Nos textos iniciais publicados por Simonsen, dos anos 1910 e início da década de 1920, a preocupação dominante era o aumento da produção, a melhora do desempenho da unidade produtiva capitalista, por meio da racionalização dos processos produtivos e da conciliação de classes. Os trabalhadores, que deveriam ser bem pagos, tinham, para Simonsen, interesses convergentes com os dos patrões. A perspectiva nacional aparecia de forma relativamente difusa: pode ser resumida na ideia de que, pelo bem da sociedade, isto é, patrões e trabalhadores deveriam cooperar e chegar a acordos. A aceitação da inserção do Brasil na

\footnotetext{
${ }^{100}$ Ver FURTADO, Celso. Formação econômica do Brasil. 34. ed. Companhia das Letras: São Paulo, 2007. cap. 13.
} 
divisão internacional do trabalho clássica, como produtor de gêneros primários permanecia praticamente inconteste.

Em "Pelo Trabalho Organizado", discurso que abre a coletânea Á margem da profissão, Roberto Simonsen louvava o trabalho conjunto, empreendido pelos operários durante o combate à gripe espanhola no município de Santos. O raciocínio subjacente à fala era centrado na importância do trabalho coletivo, organizado e cooperativo: uma preocupação mais interna à firma. Uma perspectiva mais ampla aparecia quando Simonsen se referia a "vós, operarios brasileiros, pioneiros de uma classe que apenas se esboça, a do proletariado nacional; vós, operarios estrangeiros, que emigrastes de vossos paizes" e que teriam vindo buscar no Brasil a liberdade que a pátria lhes recusava. ${ }^{101} \mathrm{~A}$ conclamação aos obreiros tinha um sentido claro de conciliação conservadora. Após louvar o espírito de solidariedade, Simonsen exortava: "E, agindo com esse pensamento, sempre unidos, contribuamos para evitar a todo transe que sejam trazidas para o Brasil as lutas de classe, as organizações artificiaes, os entraves á verdadeira noção de liberdade, que foram, em grande parte, as causas dessa campanha sangrenta que custou milhões de vidas de nossos semelhantes.". A referência era à Primeira Guerra Mundial.

Outro ponto a se destacar neste texto é a organização do trabalho. "Ha bastante tempo que me domina esse problema da organização industrial, - a organização scientifica, como a denominam os norte-americanos - que está sendo adoptada soffregamente pelos paizes mais adeantados, em todos os ramos de sua actividade, e que visa, em synthese: a maxima economia na produção pela realização da maxima efficiencia." ${ }^{102} \mathrm{O}$ raciocínio era simples: a guerra devastara as nações e só se recuperariam, no esforço do pós-guerra, as empresas mais bem organizadas. Não se falava de planejamento em nível nacional. Deveria ser buscado o barateamento da produção, sem redução salarial, mas, sim, pela obtenção da maior eficiência no trabalho. Isto era constante no pensamento de Simonsen: elogiar os altos salários pagos nos EUA, dentro da lógica taylorista/fordista, reiterando que a redução dos custos deveria ser buscada na racionalização produtiva e não via arrocho salarial.

A administração científica pode ser considerada, segundo Hobsbawm, uma "filha da Grande Depressão" dos anos 1870. F. W. Taylor (1856-1915), o fundador e principal divulgador desse tipo de estratégia de organização da produção, desenvolveu suas ideias ao longo dos anos 1880, para resolver problemas ligados à indústria siderúrgica norte-americana. Os principais fatores a impulsionar a criação da doutrina da administração científica teriam

\footnotetext{
${ }^{101}$ SIMONSEN, Roberto. "Pelo Trabalho Organizado - Resposta à saudação dos companheiros de trabalho, após a terminação da epidemia de gripe hespanhola, a 9 de dezembro de 1918”. [1918a] IN: MP, pp. 17-21.

${ }^{102}$ SIMONSEN, 1918a, p. 19. Grifo do autor.
} 
sido, para Hobsbawm, as pressões sobre os lucros, advindas da depressão econômica, e o tamanho e complexidade crescentes das firmas, que tornaram os métodos tradicionais, empíricos e improvisados, inadequados. O objetivo do "taylorismo", como ficou conhecida a administração científica, era fazer com que os operários trabalhassem mais. Para isso, os três principais métodos utilizados foram: o isolamento do operário, transferindo-se o controle do processo de trabalho aos agentes da administração; a compartimentação sistemática dos processos em unidades componentes cronometradas; e a introdução de vários sistemas escalonados de pagamento, de forma a criar incentivos à maior produção por operário. ${ }^{103} \mathrm{~A}$ administração científica do trabalho será uma questão importante e recorrente para Simonsen: para além dos vários escritos em que tocou no assunto, Simonsen foi, em 1931, um dos fundadores do IDORT (Instituto de Organização Racional do Trabalho), importante instituição de difusão dos princípio do taylorismo no Brasil.

Essa preocupação com a organização científica do trabalho e a conciliação de classes, no texto de 1918 e em outros, dos anos seguintes, além de estar na ordem do dia nas primeiras décadas do século XX, certamente está ligada às referências intelectuais de Simonsen à época, adquiridas ao longo de sua formação acadêmica. Formado em 1909 pela Escola Politécnica de São Paulo, Simonsen foi aluno da cadeira intitulada "Economia Política, Direito Administrativo e Estatística", na qual possivelmente obteve noções importantes de economia e organização do trabalho. ${ }^{104} \mathrm{O}$ próprio projeto pedagógico da Escola Politécnica de São Paulo estava ligado a esse tipo de tendência à produção e transmissão de um conhecimento técnico e prático, como reação à mentalidade livresca e ao bacharelismo, presentes no ensino superior brasileiro até então. Convém lembrar que, quando foi fundada a Escola Politécnica de São Paulo, em 1894, havia, no Brasil, poucos cursos superiores formalizados e apenas uma escola de engenharia. Havia a Faculdades de Direito de São Paulo e do Recife, a Faculdade de Medicina no Rio de Janeiro e, na área de engenharia, a Escola Politécnica do Rio de Janeiro e a Escola de Minas de Ouro Preto. ${ }^{105}$ Esse número reduzido de instituições superiores ressalta o fato de que o ensino superior era muito restrito no Brasil: no caso da turma de Roberto Simonsen, que concluiu o curso de engenharia civil, em 1909, graduaram-se apenas 13 alunos. Nesse sentido, o projeto da Politécnica era ligado a uma ideia de modernização elitista: embora questionasse o bacharelismo, a proposta era reproduzir uma instituição em moldes europeus para a elite paulista.

\footnotetext{
${ }^{103}$ HOBSBAWM, Eric. A era dos impérios: 1875-1914. 3. ed. Rio de Janeiro: Paz e Terra, 1988. pp. 71-72.

104 Anuario da Escola Polytechnica de São Paulo - 1909. Arquivo Histórico da Escola Politécnica. Ver, também, SANTOS,1985. pp. 145-150.

${ }^{105}$ AIDAR et al., 1993, p.
} 
A cadeira de "Economia Política, Direito Administrativo e Estatística" fazia parte do currículo do curso de engenheiros civis, da Escola Politécnica e, no período em que Simonsen foi aluno, era ministrada por Brazilio de Campos, engenheiro formado pela Escola Politécnica do Rio de Janeiro. ${ }^{106}$ O programa da disciplina enfatizava Economia Política e Direito Administrativo. A parte referente a Economia Política era dividida em quatro seções: "Produção da riqueza", "Circulação da riqueza", "Distribuição da riqueza" e "Consumo da riqueza". A seção referente à produção não apresenta exatamente teorias - não se mencionam autores clássicos, nem são citados manuais estrangeiros - mas, sim, uma descrição do processo de produção e de seus instrumentos e um conjunto de condições e recomendações para o desenvolvimento da produção. Depois dos itens referentes ao processo (1) e aos instrumentos de produção (2), os itens do programa se apresentam da seguinte maneira:

3. Como a industria aumenta e progride

4. Condições geraes que concorrem para o desenvolvimento da producção

5. Condições especiaes favoraveis ao desenvolvimento da producção

I. Condições intrinsecas ou de organização. a) Divisão do trabalho. b) Systema de remuneração do trabalho. Trabalho por unidade de obra; participação dos operarios nos beneficios da industria. c) Associação

II. Condições extrínsecas. d) Machinas, instrumentos, invenções e descobertas. e) Qualidades pessoaes dos trabalhadores.

III. Condições sociaes. f) Liberdade de trabalho. g) Regimen militar.

6. Organisação do trabalho.

I. Socialismo. (...). Refutação geral dos sistemas socialistas.

II. Comunismo. Absurdo das teorias comunistas; insucessos praticos.

III. Systema regulamentar.

7. Industrias ou ramos de produção. Classificação das industrias; ordem natural em que se desenvolvem.

8. Regimen economico das industrias.

I. Industria agricola.

II. Industrias manufatora e comercial. ${ }^{107}$

Percebe-se que o programa da disciplina procura responder a questões relativas ao incremento da produção, mais do que a questões teóricas. Era uma economia essencialmente aplicada. Questões abordadas no programa, como as condições gerais de incremento da produção, o sistema mais eficiente de remuneração do trabalho, a recusa ao socialismo e ao comunismo como alternativas políticas estarão presentes ao longo da obra de Simonsen, tanto nos primeiros textos quanto em elaborações posteriores. Nesse sentido, é importante reter que Simonsen adquiriu, em seu curso universitário na Politécnica de São Paulo, uma formação em engenharia calcada num projeto pedagógico voltado para o ensino técnico e contrário ao bacharelismo. Ademais, teve um contato com a economia política, como disciplina, a partir de um programa voltado para questões de organização produtiva e marcado por uma visão de

\footnotetext{
${ }^{106}$ Pasta do professor Brazilio de Campos. Arquivo Histórico da Escola Politécnica.

${ }^{107}$ Programma da Quinta cadeira do terceiro anno do curso de engenheiros civis, quarta do terceiro anno dos cursos de engenheiros industriaes e architectos e quarta do segundo anno do curso de electricistas - 1913. Arquivo Histórico da Escola Politécnica. Fundo Escola Polytechnica (1892-1934). Caixa 19.
} 
que os interesses capitalistas deveriam prevalecer sobre os do trabalho.

A ideia de vocação agrícola estava claramente presente no discurso intitulado "Orientação Agricola Brasileira"108. A produção primária era apontada como atividade-chave para geração de riqueza, como era de se esperar num discurso proferido em solenidade oferecida ao Ministro da Agricultura. Até no caso dos EUA, a atividade merecia papel de destaque: "Foi nella [agricultura] que a America buscou os elementos de vida para suas industrias ás quaes a lavoura não proporcionou apenas as matérias-primas, mas proporcionou tambem os seus capitaes". ${ }^{109} \mathrm{O}$ argumento central era que se devia, por meio do uso de técnicas científicas, incrementar a produção agrícola brasileira, nos moldes do que ocorreu nos EUA. Ressaltava-se o papel do Estado americano como fomentador da produção agrícola, distribuindo sementes, divulgando novas técnicas e métodos, mas Simonsen é enfático ao afirmar: "A acção do Estado nada tem alli de burocratica". 110

A preocupação central era que, sobretudo no pós-Primeira Guerra, "a producção, para ter efficiencia economica precisará, pois, assentar em bases scientificas". Nesse sentido, "Adeus ao doce 'laisser-aller' doutro tempo. Adeus aos negocios feitos ao acaso." "111 Mais do que uma defesa do protecionismo ou da intervenção deliberada do Estado nos negócios, o que havia era um deslocamento do eixo de importância: seriam o trabalho humano e a organização científica deste, fomentada pelo Estado "não-burocrático", que permitiriam a exploração agrícola.

No que tange ao Brasil, Simonsen fez uma descrição relativamente detalhada do território nacional, associando a "historia da exploração de nossas riquezas naturaes" à "historia da nossa conformação geológica", para exortar a "exploração generalizada e intensiva das nossas riquezas", com a consequente promoção de relações interestaduais "para que a nacionalidade brasileira se mantenha una" ${ }^{, 12}$. Era o mesmo princípio: aplicar métodos mais eficientes para um melhor aproveitamento da riqueza. Destacam-se nesse discurso a aplicação às atividades agrícolas do princípio da organização do trabalho como forma de aumentar a produtividade e a valorização da agricultura como atividade-chave, não só do Brasil, mas também do desenvolvimento dos EUA, país que, ao lado da Inglaterra, será recorrentemente tomado como modelo. Roberto Simonsen uniu, neste texto, suas preocupações ligadas ao aumento da produtividade e à organização da produção, com a necessidade de valorizar as

\footnotetext{
${ }^{108}$ SIMONSEN, Roberto. “Orientação Agricola Brasileira - Saudação ao Ministro da Agricultura, Exmo. Sr. Dr. Padua Salles, no banquete que lhe offereceu a cidade de Santos, a 27 de Dezembro de 1918”. [1918b]. IN: MP, pp. 25-33.

${ }^{109}$ SIMONSEN, 1918b, p. 28.

${ }^{110}$ SIMONSEN, 1918b, p. 29.

${ }^{111}$ SIMONSEN, 1918b, p. 28.

${ }^{112}$ SIMONSEN, 1918b, pp. 31-32.
} 
atividades agrícolas para se legitimar perante um público ligado a este setor. Certamente, o público-alvo do discurso teve influência sobre seu conteúdo, o que não invalida a ideia de que as preocupações de Simonsen, neste início de sua carreira, são distintas daquelas que terá em momentos posteriores.

Simonsen publicou dois excertos de Relatórios, que apresentou à Diretoria e à assembleia de acionistas da Companhia Construtora de Santos, em 1918 e 1919. No Relatório de 1918, o autor procurou se defender de ataques dirigidos à Construtora, por parte de "certa imprensa de Santos". Sua prestação de contas referia-se a empresas de cuja administração participou, à parte do cargo de diretor da Companhia Construtora de Santos: "Companhia Santista de Habitações Economicas", "Companhia Parque Balneario", "Companhia Brasileira de Calçamentos", "Companhia Frigorifica de Santos".

A “Companhia Santista de Habitações Economicas” merece alguma atenção, por ter sido idealizada para a construção, em Santos, de uma vila operária modelo, em período considerado chave na história da construção de vilas operárias no Brasil. Segundo Palmira Petratti Teixeira ${ }^{113}$, datam da década de 1890 os primeiros documentos em que se aventava a construção de vilas operárias, no entorno da cidade de São Paulo, como forma de melhorar ou "higienizar" - as precárias condições prevalecentes nos cortiços. Nas duas primeiras décadas do século XX, a construção de vilas operárias tornou-se negócio lucrativo: houve um movimento, do qual a empresa de Simonsen parece beneficiar-se, de incentivo estatal à iniciativa privada, para que construísse moradias operárias. O poder público limitou os juros para o capital investido em tais empreendimentos, tornando-os mais rentáveis. A construção dessas vilas também está inserida num projeto racional de moldagem de um novo trabalhador ${ }^{114}$ : se até os anos 1910, as medidas preconizadas pelos empresários ao lidar com os trabalhadores eram de caráter punitivo, o novo trabalhador que começa a surgir neste momento atua numa fábrica higiênica, que funciona de acordo com os princípios racionais defendidos por Simonsen e por outros empresários, como Jorge Street. Esses operários tinham diante de si não mais patrões arbitrários, mas, sim, benfeitores e preocupados com seu bemestar. No limite, a construção de vilas operárias era parte do projeto de construção de uma hegemonia burguesa, na medida em que permitia que vigorassem, não só no interior da fábrica, valores ligados à racionalização e ordem.

Com apoio da Câmara Municipal de Santos e de Belmiro Ribeiro ${ }^{115}$ para obtenção do

\footnotetext{
113 TEIXEIRA, Palmira Petratti. A fábrica do sonho: trajetória do industrial Jorge Street. Rio de Janeiro: Paz e Terra, 1990. pp. 69-101.

114 TEIXEIRA, 1990, p. 74.

${ }^{115}$ Belmiro Ribeiro de Morais e Silva foi um político influente na cidade de Santos, na Primeira República.
} 
capital inicial e escolha do terreno, Simonsen criou a referida Companhia, construtora de habitações operárias, com capital inicial de 500 contos. A principal realização da empresa foi a construção do Bairro Modelo, ou Vila Belmiro, cujo arruamento, nas palavras de Simonsen, “obedece aos mais modernos preceitos da 'Town-planning". ${ }^{116}$ Tratava-se de transpor, para as habitações operárias, aquilo que Simonsen defendia como princípio norteador da produção: a organização racional. Em seu relatório, Simonsen nota, no entanto, que as casas construídas por sua Companhia não eram habitadas por operários propriamente ditos: "nunca foram ellas [as casas] habitadas por operarios, propriamente, mas sim por elementos da classe média, os 'operários de casaca'". ${ }^{117}$ De fato, o preço mencionado por Simonsen, $60 \$ 000$ pelo aluguel de uma casa em Vila Belmiro, parece incompatível com a renda que um trabalhador braçal da época despenderia com habitação, ao se tomar a cifra apresentada por Palmira Petratti para a renda média desse tipo de trabalhador, em São Paulo: entre 60\$000 e 75\$000.

O estudo de Ana Lanna corrobora o relatório de Simonsen, ao salientar que o projeto de construção de habitações operárias em Santos, encampado pela Companhia Construtora, falhou devido à concorrência imposta pela construção clandestina de casas de madeira. $\mathrm{O}$ foco da empresa teria passado, a partir de então, à construção de palacetes sofisticados na região das praias. A autora insere essa tentativa de construção de moradias operárias no cenário de "guerra aos cortiços", parte do processo de transformação urbana, vivido pela cidade de Santos sob a égide do grande capital ligado ao café. Era necessário criar uma cidade para o comércio e para o consumo das elites, de acordo com padrões europeus: traços do cotidiano das populações trabalhadoras - jogos, festejos e mesmo as formas de morar - foram colocados no território do indesejável. Os cortiços, bem como seus habitantes, eram encarados como promíscuos, devendo ser alijados da nova vida urbana incorporada pela elite. ${ }^{118}$

No Relatório de 1919, o foco era mais diretamente no problema da remuneração do trabalho. Roberto Simonsen defendia que os industriais reconhecessem o descontentamento de seus operários e proporcionassem a justa remuneração do trabalho, "se não quizerem assistir ao entravamento da producção pela tentativa de decisão deste problema, erradamente, por vias políticas, quando poderia ser resolvido, com acerto, por vias econômicas." "119. Segundo o autor, o conflito de classes ocorreria por buscarem os dois grupos - capitalistas e trabalhadores - apenas interesses imediatos, em detrimento dos verdadeiros interesses de toda a sociedade. Simonsen culpava o mau sistema de pagamento por essa situação, em que os

\footnotetext{
${ }^{116}$ SIMONSEN, Roberto. "Problemas de Administração - Excerptos dos Relatorios apresentados á Directoria e assembléa de accionistas da Companhia Construtora de Santos em 1918 e 1919”. [1918/1919]. IN: MP, pp. 37-53.

${ }^{117}$ SIMONSEN, 1918/1919, p. 41.

${ }^{118}$ LANNA, 1999, pp. 104-105.

${ }^{119}$ SIMONSEN, 1918/1919, p. 49
} 
operários se reúnem coletivamente para lutar contra os patrões. Tal problema deveria ser resolvido por meio do estudo científico do processo produtivo e da individualização do trabalhador. Esse sistema científico deveria premiar, com equidade, o esforço pessoal e a variação de produtividade de um homem para outro, bem nos termos da administração científica ou "taylorista" mencionados acima. A questão operária - habitação e salário - está presente com força nesses relatórios de 1918 e 1919, como reflexo de um momento de reivindicações trabalhistas sobre o qual convém deter-se um pouco mais.

Influenciado por ideias anarquistas ${ }^{120}$, o movimento operário não despertara muita atenção da mídia e das elites brasileiras até 1917. A grande agitação trabalhista da Primeira República deu-se entre 1917 e 1920, quando se modificou essa situação, com um importante ciclo de greves nas duas principais cidades do país. Associados a essas paralisações, estão alguns fatores importantes: o agravamento da carestia, em decorrência da Primeira Guerra Mundial e a vaga revolucionária europeia, aberta com a Revolução Russa. Entre 1917 e 1920, o número de greves em São Paulo chegaria a mais de cem e no Rio de Janeiro, ultrapassaria sessenta, refletindo uma clara mudança de conjuntura. A sindicalização ganhou ímpeto e o movimento ganhou a imprensa, passando a preocupar a elite dirigente. $\mathrm{O}$ foco das paralisações foram as fábricas propriamente ditas, sobretudo as têxteis, onde havia um grande número de mulheres e crianças trabalhando.

As reivindicações dos trabalhadores eram mais relacionadas à melhoria de suas condições de vida do que à revolução social, ainda que houvesse setores movidos pelo ideal de uma sociedade igualitária. Um exemplo disso foi o Comitê de Defesa Proletária, que se formou em São Paulo em 1917 e que tinha como pontos principais de sua pauta: aumento de salários, interdição ao trabalho de menores de catorze anos, abolição do trabalho noturno para mulheres e menores de dezoito anos, jornada de oito horas, fim do trabalho nos sábados à tarde, garantia de emprego, respeito ao direito de associação.

Dentre as greves gerais do período, a mais marcante foi a de junho/julho de 1917, em São Paulo, tendo permanecido mais forte na memória histórica do movimento. Começando por

\footnotetext{
${ }^{120}$ O movimento operário da Primeira República teve características distintas nos dois principais centros industriais do Brasil. De forma bastante simplificadora, pode-se dizer que, no Rio de Janeiro, teria predominado um sindicalismo de resultados, baseado em ideias socialistas, voltado para reivindicações pontuais, como aumento salarial, salubridade no trabalho, redução da jornada. Na cidade de São Paulo, ganhou força o anarcossindicalismo, que tinha em seus horizontes uma transformação mais radical da sociedade, a ser alcançada por meio da greve geral revolucionária. Os ideais previam uma sociedade sem classes, sem Estado, organizada numa livre federação de trabalhadores. Não haveria, para os anarquistas, o interlúdio do Estado forte, administrado pelo proletariado: a luta se daria sem o Estado e até mesmo contra o Estado. Na prática, os anarquistas acabaram por pugnar pelas mesmas reivindicações feitas por seus adversários socialistas, dada a distância entre seus ideais e a realidade brasileira. Esse panorama do movimento operário brasileiro na Primeira República está em: FAUSTO, Boris. História do Brasil. 13. ed. São Paulo: Edusp, 2009. cap. 6. Para uma visão mais aprofundada do tema, ver: BATALHA, Claudio Henrique de Morais. O movimento operário na Primeira República. Rio de Janeiro: Zahar, 2000.
} 
duas fábricas têxteis, estendeu-se para quase toda a classe trabalhadora da cidade. Bairros operários como Brás, Mooca e Ipiranga estiveram por dias em mãos dos grevistas. O governo mobilizou tropas para repressão e a Marinha chegou a enviar dois navios de guerra a Santos. Houve, ao final, um acordo com os industriais e o governo, mediado por um Comitê de Jornalistas: o resultado foi um aumento salarial e vagas promessas de atendimento às demais reivindicações. No início dos anos 1920, o movimento começou a arrefecer, devido às dificuldades de organização e de obtenção de êxitos e à repressão, que se intensificou, perseguindo especialmente os líderes operários estrangeiros. ${ }^{121}$

Toda essa agitação trabalhista gerou preocupações no empresariado: era necessário responder às questões colocadas pelo movimento. No caso de Simonsen, a resposta, neste momento, era de cunho fordista: passava pela criação de condições materiais para o operariado e pelo pagamento de salários baseados na produtividade. Esse raciocínio era permeado por uma lógica corporativista de conciliação de classes.

De facto, o que o patrão procura é pagar o menos possivel por unidade de producção, e o que o operario visa é ser o mais remunerado possivel por unidade de tempo: dahi a viabilidade em ser obtida a solução harmonica dos interesses das duas classes por investigações scientificas das condições reaes do trabalho e pela applicação intelligente das leis economicas que regem a producção". ${ }^{122}$

Esse tipo de resposta às questões operárias, que procurava escamotear o conflito entre capital e trabalho, estava presente no conteúdo dado na disciplina de "Economia Política" da Escola Politécnica referida acima, cursada por Simonsen. A seção dedicada à "Distribuição da riqueza" apresenta os seguintes tópicos, dentro do item "Da parte [da riqueza] que cabe ao emprezario": "Legitimidade do lucro do emprezario. Causas que influem sobre a quota de lucros. Do pretendido antagonismo entre o lucro e o salario. Paredes de operarios, meios de evital-as ou de atenuar seus efeitos". ${ }^{123}$

Em 1919, Simonsen recebeu um convite que lhe proporcionou um destaque novo, permitindo-lhe extrapolar o meio empresarial santista: foi chamado a integrar a Missão à Inglaterra, formada pelo governo brasileiro e chefiada por Pandiá Calógeras, a qual iria à GrãBretanha, nas palavras de Simonsen "não á cata de representações ou visando um incremento provisorio de relações commerciaes, mas sim conhecer em seus largos traços os grandes progressos da indústria ingleza, e ficarem habilitados a aconselhar quaes os productos e methodos que possam ser aproveitados para a intensificação economica do Brasil" ${ }^{\text {"124 }}$. Neste

\footnotetext{
${ }^{121}$ FAUSTO, 2009, cap. 6.

${ }^{122}$ SIMONSEN, 1918/1919, p. 49.

${ }^{123}$ Programma da Quinta cadeira do terceiro anno do curso de engenheiros civis, quarta do terceiro anno dos cursos de engenheiros industriaes e architectos e quarta do segundo anno do curso de electricistas - 1913. Arquivo Histórico da Escola Politécnica. Fundo Escola Polytechnica (1892-1934). Caixa 19.

${ }^{124}$ SIMONSEN, Roberto. “Missão à Inglaterra - A) Orientação commercial brasileira”. [1919a]. IN: MP, pp. 65-66.
} 
mesmo discurso, proferido ainda no Brasil, vale destacar a crítica feita por Simonsen ao hábito dos brasileiros de encaminharem seus filhos para as profissões liberais, em vez de incentivá-los a dedicarem-se aos "negócios" ou às profissões técnicas. ${ }^{125}$ Como vimos, isso era parte do projeto pedagógico e acadêmico dentro do qual Simonsen recebeu sua formação em engenharia, na Politécnica de São Paulo: combate ao bacharelismo e à mentalidade livresca.

No que tange aos "aspectos brasileiros", Simonsen via um problema de ausência de aparelhamento técnico como o grande entrave ao enriquecimento do Brasil. "O Brasil sem minas de carvão, no estado actual da sciencia, tinha de ser naturalmente, em primeiro logar agricola e pastoril. O combustivel barato attrahe a industria; o salario alto attrahe o braço e consequentemente a população; o povoamento condensado amplia o mercado e valoriza as terras, criando riquezas e formando organizações". ${ }^{126}$ É interessante que, embora fosse reconhecida a vocação agrícola - e os outros textos da "Missão à Inglaterra" confirmam esse reconhecimento - ela não aparecia como algo irremediável em si, estando associada ao "estado actual da sciencia". Nesse trecho, há o esboço de um raciocínio econômico logicamente encadeado: uma melhora de produtividade na extração de combustível reduz os custos para a indústria, que se instala e pressiona os salários. Cria-se um afluxo populacional e valorização das terras: em suma, criam-se riquezas. Fica claro, todavia, que, neste momento, a ênfase era muito mais no aproveitamento da inserção primário-exportadora do Brasil do que em qualquer tentativa de se pensar a sua superação.

A despeito de uma valorização retórica da indústria, a sequência de discursos e artigos que compõem a "Missão à Inglaterra" mostra que as preocupações de Simonsen estavam voltadas para o reforço da corrente comercial já existente, de produtos primários. Os temas dos artigos são ilustrativos: "A indústria de carnes frigoríficas no Brasil"127 e "Opportunidades para negócios de madeira no Brasil"128.

No caso do setor de carne congelada, Simonsen defendia propostas como o estabelecimento de linhas regulares de navios frigoríficos entre Inglaterra e Brasil, inversão de capitais ingleses em terras e na indústria pecuária brasileira e a fundação de agências vendedoras de máquinas e de vagões frigoríficos. O período em questão de fato foi importante para o desenvolvimento da indústria frigorífica no Brasil: estimulado pela escassez de carne e

\footnotetext{
${ }^{125}$ SIMONSEN, 1919a, p. 59.

${ }^{126}$ SIMONSEN, 1919a, p. 62.

${ }^{127}$ SIMONSEN, Roberto. 'Missão à Inglaterra - D) A Industria de Carnes Frigorificas no Brasil. Artigo publicado no 'Times', de Londres, a 19 de Julho 1919" [1919b]. IN: MP, pp. 72-77.

${ }^{128}$ SIMONSEN, Roberto. "Missão à Inglaterra - E) Opportunidade para Negocios de Madeiras no Brasil. Artigo publicado no 'Tines' de Londres, conjuntamente com o Dr. Manoel de Souza Bandeira, em Julho de 1919’. [1919c]. IN: MP, pp. 65-66.
} 
derivados na Europa durante a Primeira Guerra, o setor frigorífico brasileiro recebeu importante incentivo governamental por meio do Decreto Legislativo 3.347, de 3 de outubro de 1917, que concedeu, por cinco anos a contar de 30 de junho de 1917, isenção de direitos alfandegários para qualquer importação de equipamento, maquinaria e utensílios, não fabricados no Brasil, necessários à implantação de frigoríficos. Essa legislação, considerada exitosa, ensejou a criação de cinco frigoríficos no Brasil, sendo um deles em Santos, administrado pela já referida Companhia Frigorifica de Santos, que foi incorporada por Roberto Simonsen. Tal empresa, entretanto, era controlada pela Companhia Mecânica e Importadora de São Paulo, que era de propriedade de Antônio Prado e Alexandre Siciliano. Os abates excessivos no período da guerra e uma geada em julho de 1918 colocaram a indústria frigorífica em dificuldades, situação que foi agravada pela valorização do mil-réis em 1919 e 1920: o resultado foi uma absorção das grandes empresas do setor pelo capital estrangeiro. A referida companhia incorporada por Simonsen foi encampada pelo Frigorífico Anglo, de origem britânica, em 1924. ${ }^{129}$

Ainda na sequência da Missão à Inglaterra, há um texto sobre metalurgia, no qual Simonsen reiterava a inserção brasileira na divisão internacional do trabalho: "Nós viemos de um paiz reconhecidamente rico em minerios de toda sorte. Vós tendes a experiencia e o capital: nós, a materia prima e a ancia do progresso. O estabelecimento de succursaes de vossas industrias no paiz e a collaboração de vossos elementos de trabalho no desenvolvimento de nossas riquezas naturaes concorrerão sem duvida para o estreitamento do intercambio anglo-brasileiro". ${ }^{130}$

Havia um projeto de modernização, no sentido furtadiano de sofisticação dos padrões de consumo, e ideias de racionalização produtiva, no âmbito da divisão internacional do trabalho tradicional. A frase seguinte sintetiza isso: "O Velho Brasil que entre o vosso povo tão pittorescamente ficou conhecido pelas suas castanhas, transformou-se em um Novo Brasil, que está neste momento desenvolvendo sua producção, justamente em artigos que a Inglaterra consome largamente"131. Ou seja: tratava-se de "desenvolver a produção", mas de produtos exportáveis para a Inglaterra. Além de integrar a Missão à Inglaterra, Simonsen foi, nesta mesma viagem, o delegado brasileiro ao Congresso Internacional dos Industriais de Algodão,

\footnotetext{
${ }^{129}$ SUZIGAN, 2000, pp. 349-361.

${ }^{130}$ SIMONSEN, Roberto. "Missão à Inglaterra - F) A Industria Metalurgica. Palavras pronunciadas em Swansea, no Cameron Hotel, em agradecimento á saudação de F. W. Gilbertson, Presidente da Bolsa de Metaes de Swansea, a 14 de Agosto de 1919”'[1919d]. IN: $M P$, p. 85 .

${ }^{131}$ SIMONSEN, Roberto. "Missão à Inglaterra - B) Relações Anglo-Brasileiras. Palavras pronunciadas no Savoy Hotel, em Londres, a 28 de Junho de 1919, no banquete offerecido pela Federação dos Industriaes Britannicos á Delegação Commercial Brasileira". [1919e]. IN: MP, p. 69.
} 
em Paris, onde apresentou um estudo, em 4 de setembro de $1919^{132}$. De acordo com o próprio Simonsen, o estudo foi bem recebido e resultou na vinda de Arno Pearce ao Brasil, com o intuito de verificar o que a Federação Internacional dos Industriais de Algodão poderia fazer para melhorar a cultura desse produto no Brasil.

Em 1920, Simonsen proferiu um discurso de paraninfo aos alunos do Mackenzie College de São Paulo. O eixo do discurso era argumentar que a profissão "homem de negócio" também poderia ser exercida de forma científica. Simonsen contestava o "business in business" e propunha, em seu lugar, o “idealismo prático". Essa ideia consiste em exercer a consciência individual no comércio e na indústria, como se fizera durante a Primeira Guerra. “(...) essas produções [durante a guerra] foram conseguidas nas organizações em que se souberam apreciar devidamente a importancia do factor humano e a necessidade de ser elle estimulado intellectual, moral e physicamente." ${ }^{133}$. Vale dizer que o princípio do idealismo prático vinha associado à ideia de conciliação de classes, de convergência de interesses entre capitalistas e operários: "Agindo com esse idealismo prático é que se poderá chegar a tão almejada conjugação de interesses entre o patrão e o operário". ${ }^{134}$ Nesse sentido, a "alma" da profissão de negócios poderia ser assim definida: "a prestação de serviços à sociedade nas questões attinentes às suas relações econômicas, empregando a verdade e promovendo o desenvolvimento do sentimento da responsabilidade social". ${ }^{135} \mathrm{O}$ ideal de homem de negócios, apontado por Simonsen, era Henry Ford: prestou grande serviço à comunidade, enriquecendo-se ao mesmo tempo.

Reforçando esse ideal de capitalista dinâmico, inovador e, ao mesmo tempo, sensível às demandas dos trabalhadores, Simonsen citou, em outro discurso, o personagem Scrooge, de Charles Dickens, para reforçar o modelo de capitalista que seus ouvintes na ocasião, formandos do Ginásio Anglo-Brasileiro, não deveriam seguir. Scrooge era descrito como "um rico usurario (...) só, isolado, não compartilhou dos periodos alegres dos seus condiscipulos, não fazia parte integrante da vida collegial". ${ }^{136} \mathrm{O}$ capitalista ideal seria aquele que cria no seu trabalho. “(...) devemos nos esforçar para saldar nossa divida para com os antepassados, que em cada geração nos legaram, augmentando-o, o patrimonio comum das cousas e das

\footnotetext{
132 SIMONSEN, Roberto. "Missão à Inglaterra - I) Possibilidades Algodoeiras no Brasil. These apresentada ao Congresso Internacional dos Industriaes de Algodão realizado em Paris, a 4 de setembro de 1919, onde o autor foi delegado unico do Brasil”. [1919f]. IN: MP, pp. 91-99.

133 SIMONSEN, Roberto. "A função dos Homens de Negocios. Conferência no Mackenzie College, a 19 de Novembro de 1920 como paranympho dos bacharelandos em commercio”. [1920a]. IN: MP, p 115.

${ }^{134}$ SIMONSEN, 1920a, p. 118.

${ }^{135}$ SIMONSEN, 1920a, p. 117.

${ }^{136}$ SIMONSEN, Roberto. "Vida de Estudante e Luta pela Vida. Discurso de paranympho na distribuição de diplomas aos bacharelandos do Gymnasio Anglo-Brasileiro, a 21 de Novembro de 1920.” [1920b]. IN: MP, p. 123.
} 
idéas." 137

Nos textos analisados até aqui, fica claro que o pensamento de Simonsen estava estruturado em torno de alguns eixos. O primeiro deles é a preocupação com o aumento da produção: era necessário produzir mais, superar as dificuldades impostas pela Primeira Guerra - e isso devia ser feito por meio da racionalização da produção, que permitiria elevar a produtividade, isto é, reduzir o custo unitário de produção a partir de uma maior eficiência dos processos produtivos. Não se deveria atingir esse resultado de redução nos custos por meio da redução de salários, mas, sim, por meio da administração científica, baseada na divisão do processo de trabalho e na remuneração escalonada, que incentivasse a maior produtividade do operário. A questão salarial era outro eixo importante: Simonsen reforçava, a todo momento, a convergência de interesses entre capital e trabalho. A luta de classes deveria ser contornada e era vista como algo irracional e que poderia (e deveria) ser evitado, por meio do referido método científico de determinação salarial. Por fim, no que tange à perspectiva nacional, há uma preocupação, muito presente nos textos da Missão à Inglaterra, com o comércio brasileiro e com as formas de se produzir no Brasil, mas não se trata de uma preocupação relacionada à superação da condição primário-exportadora pela industrialização. Pelo contrário, a ideia é reforçar as oportunidades que se apresentavam ao Brasil, no âmbito de sua inserção internacional.

$\mathrm{Na}$ carta de Simonsen à Missão Montagu ${ }^{138}$, de 1924, apareciam elementos de questionamento a um desses pontos: a inserção agrário-exportadora do Brasil. Ainda que de forma discreta e inserida na lógica da política econômica da época, o texto pode ser considerado como inovador, pelo tipo de preocupação: se antes eram os processos internos à firma que estavam em jogo, tratava-se agora da política cambial brasileira - e o autor se sentia confortável o suficiente para dirigir uma carta que continha sugestões de política econômica, não só de racionalização do trabalho com o objetivo específico de elevar a produtividade uma empresa ou de um grupo de empresas. No início da década de 1920, a principal atividade de Simonsen ainda era a construção civil. Em 1920, a Companhia Construtora de Santos, assinara o referido contrato com Pandiá Calógeras, ministro da Guerra de Epitácio Pessoa, para a construção de quartéis para o Exército. A projeção de Simonsen como líder industrial aumentou ao longo da década de 1920: em 1923, assumiu a presidência do Sindicato Nacional dos Combustíveis Líquidos e, no ano seguinte, passou a dirigir a Cerâmica São Caetano essas posições lhe davam a possibilidade de participar mais ativamente da discussão pública

\footnotetext{
${ }^{137}$ SIMONSEN, 1920b, p. 126.

${ }^{138}$ SIMONSEN, Roberto. 'Necessidade de Estabilização Cambial - Carta enviada á Missão Financeira Ingleza chefiada pelo Sir Edwin Montagu, a 8 de fevereiro de 1924." [1924]. IN: MP, p. 143-148.
} 
de questões como a política monetária e cambial. ${ }^{139}$

Antes de entrar na discussão sobre a visita de Montagu e a reação de Simonsen, vale recapitular as articulações entre a política monetária brasileira e o padrão-ouro, durante a Primeira República. Durante o período de vigência do padrão-ouro nas economias ocidentais centrais (1870-1914), o Brasil adotou a conversibilidade após o ajuste feito com o Convênio de Taubaté e a criação da Caixa de Conversão, em 1906. O câmbio fixo perduraria até 1914, quando, com a eclosão da Primeira Guerra, a Caixa foi fechada. Seguiu-se um período de câmbio flexível até 1926, quando o governo implantou uma reforma monetária e criou a Caixa de Estabilização, nos mesmos moldes da Caixa de Conversão, cujo objetivo era a emissão de notas conversíveis em ouro. Vale lembrar que, ao eclodir a crise de 1929, a primeira reação do governo Washington Luís foi aferrar-se à ortodoxia, intensificando os efeitos da recessão. Como se sabe, essa situação mostrou-se insustentável, contribuindo para a derrocada do regime político da República Velha. ${ }^{140}$

A missão Montagu, à qual Simonsen se dirigiu na carta, aconteceu devido à pretensão do governo brasileiro de levantar um empréstimo de 25 milhões de libras junto à casa Rothschild. O governo Bernardes viu-se diante da necessidade de buscar o aporte por problemas que remontavam ao contrato do empréstimo de valorização de 1922, que impedia o governo de iniciar nova operação de valorização antes da liquidação do empréstimo, prevista para ocorrer em 10 anos. Para encurtar esse prazo, o governo buscou acelerar as amortizações por meio da venda dos cafés retidos em estoque. Essas vendas rápidas conjugadas com a safra duas vezes maior que a do ano anterior em 1923, levaram a pressões depressivas sobre o preço do café na segunda metade do ano. Desse modo, o governo acabou optando por sustentar os preços, ainda que informalmente. A sustentação, no entanto, poderia tornar necessário o abandono da política monetária restritiva, que fazia parte do programa de Bernardes. Isso dependeria da capacidade do sistema bancário privado de cumprir seu papel no financiamento à retenção de estoques. Pressionados pelo aperto de liquidez e por problemas sazonais de demanda de crédito em outras lavouras, os bancos foram incapazes, a partir do terceiro trimestre de 1923, de acomodar os compromissos financeiros necessários a essa retenção para sustentação de preços. O Banco do Brasil passou, então, a lançar mão de sua faculdade de emissão e, a partir de agosto, acelerou-se a depreciação do mil-réis. O governo perdera o controle sobre a política monetária e temia uma crise cambial e seus efeitos orçamentários: o déficit público em 1923 atingiu um terço dos gastos públicos totais. Nesse

\footnotetext{
${ }^{139}$ DIAS, Sônia. "Roberto Simonsen”. IN: Dicionário histórico-biográfico brasileiro: pós-1930. Rio de Janeiro: FGV/CPDOC, 2011.pp. 5481-5485.

${ }^{140}$ FRITSCH, Winston. “Apogeu e crise na primeira república”. IN: ABREU, 1990, pp. 61-62.
} 
contexto, o governo passou a considerar a obtenção de um novo empréstimo em Londres. ${ }^{141} \mathrm{~A}$ casa Rothschild, todavia, não se dispôs a recomendar o empréstimo ao governo federal sem maiores conhecimentos da situação financeira brasileira: enviou-se ao Brasil uma missão financeira, chefiada por Edwin Montagu, com o objetivo de verificar se o país tinha condições assumir o compromisso financeiro que o empréstimo acarretaria.

O relatório privado da missão continha a recomendação de que se levantasse um novo empréstimo, dado que se cumprissem algumas propostas (imposições) feitas ao governo brasileiro. Essas medidas recomendadas incluíam: equilíbrio orçamentário, melhora na gestão do orçamento, reformas tributárias e limites ao gasto governamental. Os projetos de envolvimento do governo no setor siderúrgico deveriam ser congelados. O governo deveria considerar a venda de ativos como ferrovias e empresas de transporte para cumprir compromissos financeiros, em caso de necessidade. Uma comissão mista público-privada deveria tratar da questão das tarifas ferroviárias, ponto de atrito entre interesses britânicos e brasileiros. Por fim, o programa de valorização do café foi criticado pelo relatório. O empréstimo, afinal, não foi levantado, devido a um embargo a empréstimos externos que se implantou em Londres em meados de 1924. ${ }^{142}$

Neste contexto, Roberto Simonsen escreveu o texto chamado "Necessidade de estabilização cambial", na verdade uma carta enviada à missão Montagu em 8 de fevereiro de 1924, que Simonsen também remeteu a Washington Luís, à época presidente do estado de São Paulo e a Carlos de Campos, líder da bancada paulista na Câmara Federal. Simonsen foi enfático no início de seu texto: "Sustento que o nosso problema fundamental é o da estabilização cambial." ${ }^{\text {"143 }}$ Passava, em seguida, a uma explicação do fato de ser o café a principal fonte de crédito do Brasil, em sua balança comercial.

Sendo o café um produto de que o Brasil tem praticamente o monopolio, as oscillações cambiaes não desorganizam a sua producção. De facto, o cambio subindo muito rapidamente, é sempre possivel promover uma valorização do producto pela sua simples retenção nas mãos dos vendedores, dada a impossibilidade dos mercados irem se suprir sufficientemente de outros fornecedores. $O$ mesmo não acontece, porém, com o algodão, a carne, o fumo e outros productos agricolas e materias primas dos quaes não temos privilegio ou monopolio da producção. ${ }^{144}$ (grifo nosso).

Ou seja, o café era nossa principal fonte de recursos pela posição monopolista ocupada pelo Brasil no mercado internacional. Essa posição dava ao país, neste momento, certa independência das oscilações cambiais. No caso de outros produtos de exportação, porém, o

\footnotetext{
${ }^{141}$ FRITSCH, 1990, pp. 52-53.

${ }^{142}$ ABREU, Marcelo de Paiva e SOUZA, Pedro Carvalho Loureiro de. "'Palatable foreign control': British money doctors and central banking in South America”. Texto para Discussão, n 597. Rio de Janeiro: PUC Rio, 2011.

${ }^{143}$ SIMONSEN, 1924, p. 144.

${ }^{144}$ SIMONSEN, 1924, p. 144.
} 
comportamento da taxa de câmbio, mais especificamente a possibilidade de valorização repentina da moeda nacional, tinha papel importante, chegando a determinar a oferta ou não de tais produtos pelo Brasil. Vale lembrar que este é um momento em que o Brasil adotava um regime de câmbio flexível, estando em curso um processo de depreciação do mil-réis, como referido acima. ${ }^{145}$ "A taxa cambial ao nivel baixo em que actualmente se encontra constitue, certamente, por algum tempo, um forte premio para a exportação."146 As exportações brasileiras, todavia, não necessariamente se deveriam restringir ao café: “é incontestavel que o Brasil offerece, neste momento, uma grande opportunidade para o desenvolvimento e exportação de outros produtos."147

Simonsen propunha, então, um esquema de política econômico-financeira baseado no desenvolvimento do plantio do algodão, por considerar que o Brasil teria grande potencial para produzir este gênero, aproveitando que possuía um custo de produção mais baixo do que o norte-americano, o que tornaria a cotonicultura nacional mais competitiva que a dos EUA.

Os peritos financeiros e technicos, determinariam o custo médio da producção do
algodão nos Estados Unidos e no Brasil; e estabeleceriam, algebricamente, uma taxa
de cambio a vigorar para o Brasil, calculada de tal fórma que o custo da producção
do algodão no paiz, transformado em ouro, ficasse $10 \%$ inferior ao custo de
producção do algodão nos Estados Unidos. ${ }^{148}$

O Brasil deveria, portanto, adotar uma taxa cambial que fosse favorável ao aproveitamento dessa oportunidade identificada no setor algodoeiro. Há dois aspectos a se notar nessa proposta de Simonsen. O primeiro é bem evidente. Simonsen pretendia mostrar aos financistas ingleses que o Brasil teria condições de, com as divisas obtidas, não só pela venda de café, mas pela exportação de outros gêneros, fazer frente aos seus compromissos externos. O que estava em jogo era um empréstimo de 25 milhões de libras, por meio do qual o governo brasileiro pretendia regularizar sua situação financeira. Nesse sentido, Simonsen tencionava mostrar aos credores que o Brasil contava com outras fontes potenciais de divisas, e não somente com a lavoura cafeeira. Um segundo aspecto, talvez menos perceptível, é que Roberto Simonsen atrelava a possibilidade de o Brasil ser um país com finanças sólidas, capaz de fazer frente aos seus compromissos, à diversificação produtiva. Somente a lavoura cafeeira não seria suficiente para isso.

Não se tratava aqui de uma defesa aberta da industrialização, nem do protecionismo, como Simonsen fará em momentos posteriores de sua obra. O documento analisado é a carta de um empresário a uma missão financeira estrangeira: uma peça de convencimento, para que

\footnotetext{
${ }^{145}$ FRITSCH, 1990, p. 53.

${ }^{146}$ SIMONSEN, 1924, p. 145.

${ }^{147}$ SIMONSEN, 1924, p. 145.

${ }^{148}$ SIMONSEN, 1924, p. 146.
} 
o Brasil consiga levantar um empréstimo para regularizar suas finanças. Apareciam, no entanto, argumentos que, embora inseridos no vocabulário e na lógica da política econômica do momento, apontavam na direção da diversificação da economia brasileira. $\mathrm{O}$ raciocínio seria: o câmbio fixo (nos termos do padrão-ouro) seria importante não só para garantir a inserção do Brasil nos fluxos de capitais internacionais, mas também para que se permitisse, por meio da eliminação da incerteza cambial, a diversificação de nosso parque produtivo, por meio, por exemplo, da cotonicultura de exportação.

O argumento ficaria mais claro quando Simonsen se referisse aos "outros problemas", para além do cambial. "Debatemo-nos em forte crise de transportes, em deficiencia de organização e de credito e na falta da regularização da importação."149. O problema dos transportes deveria ser resolvido com a atração de capitais externos, sobretudo ingleses, visando ao fornecimento de material ferroviário. O encaminhamento da questão do crédito passaria pela estabilização do câmbio, que, aliada a uma "politica bancaria convincente" traria para o Brasil correntes de numerário, organização da produção e, como corolário, facilidades creditícias. Quanto à questão da pauta de importações, Simonsen era mais enfático:

\footnotetext{
Impõe-se, a meu vêr, uma politica do Governo, facilitando a importação de machinas, ferro, aço, carvão e productos medicinaes e tornando verdadeiramente prohibitivas as importações de productos de luxo. Do contrario, correremos sempre os riscos de orgias na importação em certos Estados do Brasil, em momentos de grande abundancia de recursos regionaes, prejudicando toda a nação. Essa medida em nada virá affectar a Inglaterra que é, para orgulho de seus filhos, productora principalmente de artigos de primeira necessidade. ${ }^{150}$ (grifo nosso).
}

Há aqui novamente dois eixos de análise. Por um lado, Simonsen pretendia mostrar aos ingleses que o Brasil não desperdiçaria divisas com importações de produtos de consumo conspícuo, de modo a priorizar compromissos financeiros, como o empréstimo que se desejava levantar em Londres. Por outro, as importações deveriam ser controladas por meio de uma política consciente do governo, de modo a garantir o fornecimento dos insumos necessários à indústria nacional em vias de se implantar: "machinas, ferro, aço, carvão". Mais uma vez, a solidez brasileira passava não só por uma política de "economia de divisas" para fazer frente aos compromissos externos, mas pela diversificação produtiva. No caso do trecho acima, passava pelo fomento à indústria que se instalava, por meio de uma política deliberada de discriminação de importações, de forma a priorizar os interesses da indústria de transformação que se implantava.

A reivindicação de uma política de discriminação de importações faz sentido ao se notar

\footnotetext{
${ }^{149}$ SIMONSEN, 1924, p. 146.

${ }^{150}$ SIMONSEN, 1924, p. 147.
} 
que a década de 1920 foi um momento de diversificação da indústria brasileira. O investimento na indústria de transformação passava a não se concentrar primordialmente em ramos complementares à economia exportadora: diversificava-se para os setores de bens intermediários, como cimento, ferro e aço, produtos químicos, fertilizantes, papel e celulose e para o setor de bens de capital. Nesse sentido, Simonsen estava fazendo a reivindicação da parte de uma indústria que estava em expansão e diversificação da capacidade produtiva (o investimento industrial se mantém elevado para praticamente toda a década de 1920, segundo Suzigan), mas dependia fortemente de importações estratégicas. Era elevado grau de dependência externa, sobretudo no que se refere ao fornecimento de insumos e bens de capital. $^{151}$

Pretende-se frisar que, embora dentro de um contexto de aceitação da inserção primárioexportadora e da política econômica ditada pela potência britânica, voltada para o pagamento dos compromissos externos, Simonsen trouxe, em sua carta, elementos das necessidades de um setor industrial em diversificação. A linguagem usada ainda é a da ortodoxia dos money doctors. ${ }^{152}$ Simonsen mostrava à missão Montagu que o Brasil tinha capacidade de pagamento para contrair um empréstimo externo. Mas, para tal, a economia brasileira deveria passar por certas reformulações, na direção da diversificação produtiva, tanto no setor agrícola, quanto na indústria.

A sugestão de que o governo deveria, conscientemente, discriminar importações em favor dos insumos industriais não era algo que se incluía no receituário professado pela missão inglesa. Ademais, vale lembrar que, neste momento, embora houvesse um problema cambial, ainda não estava em curso a mudança estrutural trazida pela industrialização: o eixo dinâmico da economia brasileira era dado pelo setor exportador e não pela acumulação industrial. No âmbito do Estado também não havia projeto claro de industrialização planejada: predominava o capital mercantil, ligado à agroexportação. A proposta de discriminação de importações em favor dos insumos e equipamentos industriais, em 1924, tinha, portanto, um elemento inovador digno de destaque.

O argumento simonseniano, neste momento de início dos anos 1920, ainda não incorporava questões como a superação do atraso ou a industrialização programada, que

\footnotetext{
${ }^{151}$ SUZIGAN, 2000. pp. 90-93 e pp. 261-264.

${ }^{152}$ Money doctor é o nome dado aos "conselheiros de finanças" que prescrevem um receituário de política econômica aos países subdesenvolvidos. A denominação "ortodoxia” dos money doctors ou ortodoxia da finança internacional é associada a agentes de grandes grupos financeiros ingleses ou americanos que, geralmente, recomendam aos países periféricos políticas de austeridade monetária e fiscal, que priorizem o pagamento de seus compromissos externos. No período em questão, as primeiras décadas do séc. XX, prevaleciam os money doctors ingleses na América do Sul. Sobre esse tema, ver: FLANDREAU, Marc. Money doctors: the experience of international financial advising 1850-2000. New York: Routledge, 2003
} 
Simonsen abordará posteriormente: o que fica claro é que, para ser um país financeiramente sólido, o Brasil deveria adotar certas prioridades, na direção da diversificação da sua pauta de exportações e do fomento à indústria. Era uma argumentação, relativa aos problemas brasileiros, que incorporava sugestões de diversificação produtiva e de incremento das atividades de transformação, embora não estivesse calcada num sólido projeto industrialista.

Quando do encaminhamento do projeto de reforma monetária do presidente Washington Luís ao Congresso, em 2 de dezembro de 1926, Roberto Simonsen concedeu uma entrevista ao diário $O$ Jornal, de Assis Chateaubriand, publicada em 16 de dezembro deste mesmo ano. Tratava-se do projeto do "câmbio vil", que visava à estabilização da moeda brasileira, nos termos do padrão-ouro. Basicamente, propunha-se uma taxa cambial máxima em ouro, que não poderia ser ultrapassada: caso o fosse, o governo adquiriria as divisas excedentes. Era uma estabilização que, nos termos colocados por Fritsch e Franco ${ }^{153}$, visava a conter uma "valorização disruptiva": a um período de ajuste recessivo, como fora o governo Bernardes, seguia-se uma apreciação cambial que podia atingir níveis considerados excessivos. Simonsen era favorável à reforma, com base na ideia de que a incerteza cambial prejudicaria os cálculos dos produtores: eliminada esta insegurança, as classes produtivas nacionais poderiam fazer suas previsões mais precisamente. Seu raciocínio passava por um mecanismo simples de ajuste monetário:

Cada vez que as classes produtoras exercem um esforço de expansão, aumentando a sua produção, segue-se, fatalmente, uma valorização brusca da moeda, caindo os preços em mil-réis, a maior parte das vezes abaixo do custo da produção, porquanto as oscilações cambiais têm correspondido a valores muito maiores que a margem de lucro que iria auferir o produtor ou o industrial. ${ }^{154}$

O ajuste implícito nesse raciocínio ocorreria, aparentemente, via entrada de divisas. Simonsen supunha que a produção resultante do "esforço de expansão" encontraria colocação no mercado internacional, gerando um afluxo de moeda estrangeira, que valorizaria o mil-réis, reduzindo os preços em moeda doméstica. A taxa máxima, aplicada na primeira fase do projeto de Washington Luís, garantiria, assim, às classes produtoras brasileiras, uma receita mínima, portanto um ganho mínimo projetável, em mil-réis. Caso o câmbio se desvalorizasse, haveria, para Simonsen, um ajuste automático.

A primeira fase em que se vai desenvolver a execução da nova lei não pode, a meu ver, evitar a baixa cambial se, conforme opinião de muitos entendidos das atuais condições econômicas e financeiras do país, resultar essa tendência. Mas, existindo esse limite de alta, qualquer tendência para a baixa cambial será corrigida

\footnotetext{
${ }^{153}$ FRITSCH e FRANCO, 1992.

${ }^{154}$ SIMONSEN, Roberto. "Projeto de Reforma Monetária". [1926, publicado também em MP, pp. 151-154]. IN: EIB, pp. 6669.
} 
imediatamente por um crescimento da nossa produção exportável. Essa baixa funcionará como um prêmio à produção e a tendência niveladora será irresistível. ${ }^{155}$

O mecanismo de ajuste era o do modelo clássico de funcionamento do padrão-ouro: a baixa cambial tornaria o produto doméstico mais competitivo, melhorando sua aceitação pelo mercado internacional, o que proporcionaria entrada de divisas, que corrigiriam a desvalorização inicial. Fica claro, nesta entrevista, que Simonsen se utilizava de fundamentos da teoria monetária convencional para balizar seu posicionamento sobre a reforma cambial. Era uma argumentação bem diferente daquela que apresentaria, no final dos anos $1930^{156}$, que já incorporava a ideia de que as divisas geradas pelas exportações eram insuficientes, havendo uma tendência à baixa cambial crônica, ao desequilíbrio - e não a "tendência niveladora irresistível" - resultando dessa situação o fomento à produção substitutiva nacional. Ainda assim, a preocupação de Simonsen não era exclusivamente monetária: havia uma ideia, relacionada às elaborações anteriores sobre a eficiência e a organização do trabalho, que articulava a estabilização cambial, nos termos da política econômica adotada pelo governo, e o fomento às atividades produtivas.

\begin{abstract}
Sendo o barateamento da produção uma consequência da organização e esta por sua vez uma consequência da continuidade da produção e da sua expansão, claro é que no regime atual nos apresentamos desarmados e pobres na concorrência internacional. Com a fixação do máximo da taxa cambial, o agricultor e o industrial brasileiro só conhecerão como limites da sua expansão a organização e os preços da concorrência estrangeira; não sofrerão mais a amputação violenta da oscilação cambial para a alta. ${ }^{157}$
\end{abstract}

O objetivo da estabilização cambial era, portanto, reduzir a incerteza para o agricultor e para o industrial, pois a redução dos custos - e a maior competitividade - deveriam ser alcançados por meio de uma produção contínua e que poderia se expandir. Essa ideia, ainda pouco desenvolvida aqui, ganhará força nas discussões sobre planejamento econômico, em que Simonsen, apoiado já numa literatura específica sobre planejamento, defenderá o plano como forma de reduzir a incerteza causadora do ciclo econômico, minorando assim os efeitos das baixas cíclicas sobre o sistema econômico-social como um todo. Mais uma vez, trata-se de um texto inserido na lógica da inserção externa clássica do Brasil e que defendia a política econômica voltada para austeridade e o cumprimento dos compromissos ligados à finança internacional.

Mais enfático foi o discurso pronunciado por Simonsen em 1928, por ocasião da fundação do Centro das Indústrias do Estado de São Paulo (CIESP). A fundação do CIESP foi um momento importante na formação do sistema corporativo de representação industrial no

\footnotetext{
${ }^{155}$ SIMONSEN, 1926, p. 68.

${ }^{156}$ SIMONSEN, Roberto. A evolução industrial do Brasil. São Paulo: FIESP, 1939.

${ }^{157}$ SIMONSEN, 1926, p. 67.
} 
Brasil, que tinha como órgãos-chave as associações representativas. ${ }^{158}$ O CIESP surgiu, em 1928, como dissidência da Associação Comercial de São Paulo. A AC-SP, fundada em 1894, congregara os interesses tanto da indústria quanto do comércio no estado de São Paulo: neste momento o grande capital comercial era o eixo da vida econômica paulista, situação que foi se tornando mais complexa ao longo da Primeira República, à medida que a indústria crescia e se diversificava. Com a valorização cambial de 1924-1925, decorrente da política cambial do presidente Bernardes, a indústria passou por situação difícil: em 1926, o mercado brasileiro foi inundado por tecidos estrangeiros, principalmente ingleses. Os industriais têxteis começaram a pressionar por um aumento de tarifas, no que não foram apoiados por seus colegas ligados ao comércio: a Associação não lhes deu apoio. Em 1928, quando da eleição para a diretoria da entidade, Jorge Street, antigo líder do CIB, encabeçou uma chapa ligada aos interesses industriais, de oposição à chapa oficial, ligada ao comércio. Tentou-se uma conciliação, mas os industriais recusaram o acordo. A cisão, portanto, ocorreu e foi formado o CIESP, tendo como primeiro presidente Francisco Matarazzo. A vice-presidência foi ocupada por Roberto Simonsen. ${ }^{159}$

O discurso proferido na fundação do CIESP, publicado como "Orientação Industrial Brasileira"160 é uma peça de defesa do papel da indústria nacional para o desenvolvimento do Brasil. Embora ainda estivesse presente a ideia de uma simbiose entre indústria e agricultura, este texto constituiu um passo decisivo na associação da indústria aos interesses nacionais, sugerindo a noção de que o desenvolvimento do Brasil, como nação, dependia da pujança do setor industrial. Simonsen destacava, de início, que, em todo o mundo, "as indústrias são consideradas padrão do adiantamento de um povo" e exaltava os ganhos de produtividade trazidos pela indústria movida a máquinas, as quais "reduziram o preço de custo das utilidades, pondo ao alcance dos bolsos mais modestos o que dantes era privilégio dos ricos". ${ }^{161}$ No caso brasileiro, a concepção ainda era de preponderância da agricultura, mas a indústria tinha papel fundamental na construção da nação independente.

Se é certo que a base da estrutura econômica do Brasil deve repousar na cultura da terra, não é menos certo que no estágio atual da civilização, a independência econômica de uma grande nação, seu prestígio e sua atuação política como povo independente no concerto das nações só podem ser tomados na consideração devida,

\footnotetext{
${ }^{158}$ Ver LEOPOLDI, 2000. Para a autora, o sistema corporativo de representação industrial se forma ao longo da Primeira República, ganha força nos anos 1920, com a consolidação das associações industriais, chegando ao seu apogeu na Era Vargas. Esse sistema se alteraria significativamente a partir dos anos 1950, com as associações setoriais específicas ganhando força.

${ }^{159}$ Sobre a cisão dos industriais em 1928 ver: PERISSINOTTO, 1994, pp. 135-136 e SAES, Alexandre Macchione; CYTRYNOVICZ, Monica Mussati; CYTRYNOVICZ, Roney. História da Federação do Comércio do Estado de São Paulo. Fecomércio 70 anos. São Paulo: Federação do Comércio, 2008. Ver também CEPÊDA, 2003, pp. 226-227.

${ }^{160}$ SIMONSEN, Roberto. “Orientação Industrial Brasileira”. [1928]. IN: EIB, pp. 53-69.

${ }^{161}$ SIMONSEN, 1928, p. 54.
} 
possuindo este país um Parque Industrial eficiente, na altura de seu desenvolvimento agrícola. $^{162}$

O eixo do texto era uma contestação ao conceito de indústria artificial, aquela que depende de insumos e matéria-prima importados, ao contrário da indústria natural, que aproveita os recursos presentes no país. O debate indústria natural versus indústria artificial tinha raízes anteriores ao período de atuação de Simonsen e remontava às discussões pioneiras sobre industrialização, ainda no período imperial. ${ }^{163}$ Esse caráter artificial era atribuído à indústria brasileira com o intuito de desqualificá-la, associando-a ao parasitismo, ao monopólio e à ideia de que produzia de forma ineficiente, encarecendo os produtos. Ao contestar a concepção de indústria artificial, Simonsen respondeu a cinco acusações, direcionadas à indústria nacional: a) A indústria importava a matéria-prima do estrangeiro; b) Não contribuía para o enriquecimento do Brasil; c) Elevava o custo de vida da população, por produzir sob tarifas protecionistas; d) Deslocava braços e perturbava a mão de obra agrícola; e, e) Constituía um monopólio em favor de alguns poucos industriais. ${ }^{164}$

Para responder à acusação de que a indústria nacional importava suas matérias-primas e, portanto, seria artificial, Simonsen citou o exemplo inglês. Argumentava que, a pensar dessa maneira, a Inglaterra não seria um país industrial, visto que importava $65 \%$ de sua matériaprima, ao passo que o Brasil importava 20\%. "O industrialismo na Inglaterra teve o seu grande desenvolvimento com o monopólio que soube criar de abastecimento industrial às suas colônias". ${ }^{165}$ Simonsen percebia que, na medida em que estabeleceu uma relação colonial com diversas regiões do globo, retirando-lhes matéria-prima e fornecendo-lhes produtos industriais, a Inglaterra teria atingido um desenvolvimento industrial sólido.

No que se refere ao enriquecimento, Simonsen apresentou o argumento da produtividade: "A grande indústria, por toda a parte do mundo em que se instala, traz como corolário a melhoria dos salários, o barateamento relativo do produto, o enriquecimento social e o aumento da capacidade do consumo"166. Além disso, a indústria traria a intensificação dos transportes e das relações comerciais. Nesse sentido, o protecionismo associado à indústria não seria empecilho ao fomento do comércio exterior. Simonsen considerava que não existia,

\footnotetext{
${ }^{162}$ SIMONSEN, 1928, p. 55.

${ }^{163}$ Segundo Nícia Vilela Luz, a distinção entre indústria artificial e indústrias natural já estava presente no Império: a tarifa Alves Branco, por exemplo, já tinha uma tendência de favorecimento a indústrias cujas matérias-primas fossem produzidas no Brasil. Ao taxar em $50 \%$ a juta, a referida tarifa visava à sua progressiva substituição por fibras nacionais. Foi com a crise da primeira década republicana, contudo, que a ideia teria tomado corpo, dando ensejo a duas correntes críticas ao industrialismo: uma, mais radical, representada por Joaquim Murtinho, recusava qualquer tipo de proteção; a outra, representada por Américo Werneck, enfatizava a solidariedade entre agricultura e indústria, criticando o artificialismo do desenvolvimento industrial brasileiro. Ver LUZ, Nícia Vilela. A luta pela industrialização do Brasil: 1808-1930. 2. ed. São Paulo: Alfa-Ômega, 1975.

${ }^{164}$ SIMONSEN, 1928, p. 56.

165 SIMONSEN, 1928, p. 57. Simonsen não cita as fontes dos dados que refere.

${ }^{166}$ SIMONSEN, 1928, p. 57.
} 
de fato, um regime protecionista no Brasil e que, se havia tarifas aduaneiras altas, estas "respondem, porém, precipuamente antes a exigências do tesouro que a intuitos protecionistas". ${ }^{167} \mathrm{Na}$ visão do autor, haveria falta - e não excesso - de protecionismo, num país cuja política tarifária, ainda que beneficiasse indiretamente setores industriais, era conduzida de acordo com as necessidades do Estado, cuja principal fonte de financiamento era o imposto de importação. "Uma política protecionista organizada para o desenvolvimento das indústrias, desonera as matérias-primas, pouco grava os produtos semiindustrializados, fazendo incidir os impostos aduaneiros principalmente sobre os produtos manufaturados." 168

À acusação de deslocamento de braços da agricultura, Simonsen contrapôs os dados do censo de 1920, segundo os quais na agricultura estavam ocupados $21 \%$ da população, ao passo que na indústria "em geral" (incluindo edificações e vestuários) atuavam 3,8\%. Na indústria fabril propriamente dita, ocupavam-se somente pouco mais de $1 \%$ da população. Além disso, a indústria empregava operários especializados, argumentava o autor, que não eram disputados com as atividades agrícolas. ${ }^{169}$

O problema do monopólio, no setor industrial, que acabaria por gerar carestia de vida, era abordado mudando a ótica da questão.

\footnotetext{
"Aos que procuram sinceramente determinar as razões do encarecimento da vida no Brasil, aconselharia que estudassem serenamente o problema e chegariam à conclusão de que no Brasil não existe vida cara, mas sim, ganho insuficiente, porque o índice de produção é baixo em relação à população e extensão do nosso território" ${ }^{170}$ (grifo do autor)
}

A vida não seria cara devido ao fato de a produção ser artificial ou onerosa, mas, sim, por ser insuficiente para gerar um ganho médio que desse ao brasileiro a possibilidade de consumir. Nesse sentido, o aumento de preços - a vida cara - estaria relacionado às insuficiências do parque produtivo brasileiro, incapaz de gerar um mercado interno pujante devido ao baixo volume de produção com relação à população. Simonsen não tocava na questão da distribuição como possibilidade de atenuar o ganho insuficiente. A solução estaria no aumento do ganho médio "e esse aumento do ganho médio está ligado ao aumento da eficiência do trabalho e, portanto, aos problemas principais da formação da nossa nacionalidade, organização do nosso aparelhamento econômico, moeda sã, crédito abundante e instrução". ${ }^{171}$

Essa passagem sintetiza, de certa forma, o percurso de Simonsen até aqui, justamente por

\footnotetext{
${ }^{167}$ SIMONSEN, 1928, p. 58.

${ }^{168}$ SIMONSEN, 1928, p. 58.

${ }^{169}$ SIMONSEN, 1928, p. 59.

${ }^{170}$ SIMONSEN, 1928, pp. 60-61.

${ }^{171}$ SIMONSEN, 1928, p. 61.
} 
retomar as preocupações iniciais do autor que, como diretor da Companhia Construtora de Santos, propugnava a melhor organização do trabalho e os altos salários como forma de tornar mais produtivas as empresas que dirigia. Neste discurso, contudo, esse raciocínio aparece para subsidiar a ideia de que a indústria brasileira não era artificial: pelo contrário, teria uma contribuição fundamental a ser dada para o desenvolvimento nacional. Mais do que isso, o desenvolvimento brasileiro passa a ser quase um sinônimo de industrialização. Essa ideia, que não foi forjada somente por Simonsen, mas que este ajudou a construir e solidificar, é forte e marcará os debates brasileiros e latino-americanos sobre desenvolvimento econômico, chegando a influenciar não só o estruturalismo cepalino, mas diversos pensadores que foram chamados a se posicionar sobre a questão do atraso econômico e sua superação.

Como se procurou mostrar, o discurso de 1928 é um marco, mas apresentava continuidades: afinal, a solução para o problema continuava sendo a mesma apresentada nos relatórios da Companhia Construtora de Santos: a melhor organização do trabalho, o melhor aparelhamento econômico, o crédito. Porém, tais soluções vinham associadas à afirmação do desenvolvimento industrial como fundamental para o desenvolvimento brasileiro: os argumentos relacionados à eficiência e ao aumento da produção eram os mesmos, mas mudava a perspectiva. Tratava-se agora de uma perspectiva nacional, que relacionava o projeto de uma classe específica - a dos industriais - à independência econômica da nação e a seu desenvolvimento de forma geral.

Em 1930, Simonsen publicou um estudo - As crises no Brasil - que difere dos trabalhos escritos até aqui, por seu caráter mais abrangente e pelas tentativas de se fazer especulações teóricas: no caso, o objeto de teorização é a crise econômica mundial que eclodira em 1929. A tônica do nacionalismo industrialista, contudo, é bem semelhante àquela que se apresentava em 1928. ${ }^{172}$ Já no prefácio, Simonsen reafirmava a argumentação de trabalhos anteriores: a indústria não podia ser acusada de responsável pela elevação do custo de vida do brasileiro, pois o aumento dos custos de produção acarretado pelo protecionismo industrial não era culpa da proteção em si, mas resultado de uma produção que se realizava num país novo e desordenado. ${ }^{173}$ Havia uma ideia de solidariedade econômica, por meio do crédito: industriais deveriam aplicar seus fundos em títulos de crédito agrícola e agricultores e consumidores deveriam aplicar saldos em títulos de empresas industriais. A crise econômica levava a conflitos que deveriam ser debelados, em nome do interesse nacional: tanto sobre os conflitos setoriais indústria-agricultura quanto sobre a luta de classes (capital/trabalho) deveria prevalecer o interesse do país. Simonsen elaborou seu estudo com o objetivo de reforçar esse

\footnotetext{
172 SIMONSEN, Roberto. As crises no Brasil. São Paulo: São Paulo Editora, 1930.

${ }^{173}$ SIMONSEN, 1930, pp. 3-5.
} 
combate à crise, lesiva ao progresso e à coesão do país: "Nada mais prejudicial, de facto, aos interesses do paiz do que essa lucta de classes. A comprehensão do phenomeno da crise, da origem de suas causas, poderá, talvez, arrefecer o ardor de combatentes sinceros, porém, mal

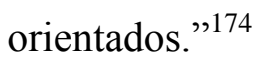

Simonsen fez um esboço das possíveis causas das crises econômicas, baseando-se numa classificação feita por Maurice Ansiaux, conforme citação do próprio Simonsen. De acordo com essa classificação, as crises teriam origens físicas, políticas, morais e técnicas. Essa tipologia referida por Simonsen está presente na Segunda Parte do Traité d'économie politique, publicado em 1926, por Maurice Ansiaux. ${ }^{175}$ Ansiaux (1869-1943) foi um economista belga, professor da Universidade de Bruxelas. A pesquisa em economia na Bélgica dos primeiros anos do século XX esteve associada à figura do industrial e economista Ernest Solvay, que financiou instituições ligadas à Universidade de Bruxelas, onde Ansiaux e outros economistas desenvolveram suas pesquisas. ${ }^{176} \mathrm{Na}$ Segunda Parte da obra referida, Ansiaux procurou esboçar uma teoria das crises econômicas. Em linhas gerais, sua ideia era que as crises econômicas são fenômenos cíclicos e, ao mesmo tempo, históricos. "Se ela [a crise] conservou certos caracteres fundamentais, transformou-se, entretanto, tão profundamente que se tornou quase irreconhecível". ${ }^{177}$ Aquilo que é típico e invariável neste fenômeno seria a alternância entre altas e baixas, já as condições segundo as quais se manifesta essa alternância estariam sujeitas à evolução da "organização econômica". As crises deixaram de ser comerciais para se tornarem industriais - e o problema mais grave da fase de regressão econômica pós-crise passou a ser o excesso de meios de produção, mais do que de mercadorias invendáveis. Entre as referências utilizadas por Ansiaux, estão autores como Schmoller, Juglar e Sombart. A ideia de que os determinantes das crises alteram-se ao longo da história também estava presente na distinção, feita por Simonsen, entre as crises brasileiras do século XIX e do século XX, como será visto mais adiante.

$\mathrm{Na}$ economia moderna, seguia Simonsen, um fator responsável por crises econômicas seria o crédito: nas fases de prosperidade, devido ao "caracteristico psycologico dos negocios de credito, a capitalização é inevitavelmente exagerada". ${ }^{178}$ Mesmo com um sistema bancário desenvolvido, seria difícil evitar crises. As formas de atenuar as crises de crédito eram, para Simonsen, a melhoria dos métodos de produção e de capitalização, além do fortalecimento da

\footnotetext{
${ }^{174}$ SIMONSEN, 1930, p. 3.

175 ANSIAUX, Maurice. Traité d'économie politique. Tome troisième. Paris: Marcel Giard, 1926. O livro se encontra na Biblioteca da FEA/USP.

${ }^{176}$ ERREYGERS, Guido. “Economics in Belgium”. IN: The New Palgrave Dictionary of Economics. Online Edition. Palgrave Macmillan, 2009.

${ }^{177}$ ANSIAUX, 1926, p. 179.

${ }^{178}$ SIMONSEN, 1930, p. 7.
} 
procura e do poder aquisitivo dos consumidores. As crises de origem acidental (de natureza política, moral ou técnica) só poderiam ser evitadas ou atenuadas por meio dos aperfeiçoamentos humanos: "o desenvolvimento do civismo, da instrucção, do ensino technico, a vulgarização dos ensinamentos de economia politica, o estabelecimento de instituições de pesquizas scientificas". 179

Simonsen se baseou em trabalho publicado de Albert Aftalion para fazer uma descrição da crise mundial corrente em 1930: os principais sintomas desta crise seriam o elevado número de desocupados e a deflação. O diagnóstico mais vulgar das causas da crise a vinculava às depressões cíclicas, mas Simonsen destacava que alguns economistas relacionavam o declínio econômico a desequilíbrios oriundos da Primeira Guerra. A situação de destruição geral, além de transformar e deslocar os centros da geografia econômica mundial, teria gerado um esforço de reconstrução que acabou por escoar sua produção no vazio deixado pela guerra. Configurou-se uma situação de superprodução. Outro motivo para a crise, elencado por Simonsen, era de ordem monetária e se referia a deficiências na produção de ouro, justamente num momento em que diversos países procuravam estabilizar suas moedas. ${ }^{180}$

O artigo de Aftalion, citado por Simonsen para descrever a crise mundial que se agravava ao longo de 1930, foi resumido ao final do livro As crises no Brasil e, segundo Simonsen, teria sido publicado pela revista "La Revue de Paris", número 14, sem informações sobre data. A Revue de Paris de fato registra, no quarto volume de 1930 (julho-agosto), um texto de Albert Aftalion, intitulado "La Crise Mondiale": pelo que indica a comparação com o resumo publicado no Brasil, seria este o texto consultado por Simonsen em 1930. Conforme o resumo, o texto se debruçava sobre a crise mundial, em especial sobre as suas origens, nos Estados Unidos. O diagnóstico era que a quebra da Bolsa de Nova York em 1929 não era a causa da crise, mas um sintoma: sua causa era, assim como em crises anteriores, a superprodução. ${ }^{181}$ Nas palavras do próprio Aftalion: "Crise periódica, a crise de 1929 foi, pois, como suas antecessoras, uma crise de superprodução. (...). A causa principal e imediata da crise americana consiste no crescimento excessivamente rápido da produção."182

Tratava-se de uma crise periódica, agravada pela queda dos valores negociados na Bolsa, em outubro de 1929: segundo Aftalion, a queda já era há muito prevista. Aftalion via, como fator distintivo da crise desencadeada em 1929, a sua escala: era uma crise mundial. Para isso

\footnotetext{
${ }^{179}$ SIMONSEN, 1930, p. 10.

${ }^{180}$ SIMONSEN, 1930, pp. 11-14

${ }^{181}$ SIMONSEN, 1930, p. 48.

182 AFTALION, Albert. "La Crise Mondiale". IN: La Revue de Paris. vol. 4 (jul-ago), 1930. p. 296. Acervo da Bibliothèque Nacionale de France. Disponível em: < http://visualiseur.bnf.fr >. Acesso em: 01/09/2013.
} 
teriam contribuído duas razões principais: a crise teria encontrado os países europeus em situações frágeis, a braços com a reconstrução de suas economias após a Primeira Guerra, e o cenário mundial era de superprodução de matérias-primas, forçando uma deflação global. ${ }^{183}$ Simonsen resumiu esse ponto: "Além do enfraquecimento economico de diversos paizes, a super-producção mundial das materias primas internacionaes, trazendo a baixa geral dos preços, concorreu para que a crise se tornasse mundial". ${ }^{184}$

Embora Simonsen não cite nenhum outro texto de Aftalion além do referido artigo, há indícios de que sua obra circulou no Brasil, e em São Paulo em particular. Diversas edições de livros seus encontram-se em bibliotecas da USP e da Unicamp, embora nenhum deles especificamente na Coleção Roberto Simonsen. Entre essas obras, vale destacar duas: Monnaie et industrie: les grands problèmes de l'heure présente (Paris: Sirey, 1929), uma compilação de artigos publicados em periódicos, e Monnaie, prix et change: expériences récentes et théorie (Bordeaux: Cadoret, 1927), um livro de teoria monetária. De forma muito sintética, o objetivo das duas obras, sobretudo da de 1927, é, por meio da apresentação de evidências factuais, colocar em questão a teoria monetária tradicional (quantitativa), que via na quantidade de moeda em circulação a causa das flutuações no valor da moeda e, por conseguinte, nos preços. A proposta de Aftalion era incorporar fatores cambiais e psicológicos à teoria monetária.

A influência do câmbio sobre os preços internos invertia a causalidade implicada na teoria da paridade de poder compra, derivação lógica da teoria quantitativa: se vale a paridade, os diferenciais de preços internos entre pares de países explicam a trajetória da taxa de câmbio entre suas moedas. Para Aftalion, baseado nas experiências francesa, alemã e austríaca dos anos 1920, a causalidade seria inversa: o câmbio explica a paridade, ao influenciar os preços internos dos países. ${ }^{185}$

Os fatores psicológicos se relacionavam com um desdobramento da teoria do valorutilidade para a moeda: Aftalion assumia que a utilidade de um bem depende da satisfação que ele é capaz de proporcionar a seu possuidor - e seria determinada pela última unidade adquirida do bem. No caso da moeda, que não proporciona satisfação, seu valor, para o indivíduo, dependeria de quanto este espera obter com uma unidade monetária, isto é, de sua expectativa, ou de sua previsão, daquilo que poderá adquirir com esse dinheiro. Esse seria o fator psicológico fundamental envolvido na determinação do valor da moeda e, portanto, dos

\footnotetext{
${ }^{183}$ AFTALION, 1930, p. 298-299.

${ }^{184}$ SIMONSEN, 1930, p. 49.

${ }^{185}$ AFTALION, Albert. Monnaie, prix et change: expériences récentes et théorie. Bordeaux: Cadoret, 1927. p. 190.
} 
preços. $^{186}$

Simonsen não se aprofundou na teoria monetária de Aftalion, destacando apenas seu diagnóstico da crise. Segundo Nenovsky ${ }^{187}$, Aftalion tornou-se mais conhecido, fora da França, por sua teoria dos ciclos econômicos e do acelerador do que por sua teoria psicológica da taxa de câmbio e da moeda. No período entreguerras, contudo, o autor era um dos economistas franceses mais influentes: professor de estatística e depois de economia política na Sorbonne, Aftalion era frequente nos principais periódicos francófonos da época. A contribuição de Aftalion, que nasceu na Bulgária e radicou-se na França, teria sido, ainda conforme Nenovsky, enriquecer a teoria monetária: teria sido um dos primeiros economistas a incorporar fatores psicológicos, expectativas e confiança ao analisar a inflação, o câmbio e a circulação monetária.

Passando da questão mais geral da caracterização da crise mundial para o entendimento específico da manifestação da crise no Brasil, Simonsen transcreveu notas, segundo ele, escritas em 27 de outubro de 1929, que havia apresentado ao presidente do Banco do Brasil e ao presidente da República, Washington Luís. A crise vivida pelo Brasil neste momento era, segundo as notas, resultado de cinco causas principais: a superprodução de café, a crise financeira internacional, a política do Banco do Brasil, a agitação política relacionada à sucessão presidencial e a falta de elasticidade do meio circulante. ${ }^{188}$

A última causa, sugerida por Simonsen, merece especial atenção pelo uso que o autor fez da teoria quantitativa da moeda para reforçar o argumento de que as autoridades deveriam manter elevada a elasticidade do meio circulante, isto é, ele deveria adequar-se, com facilidade, às necessidades dos negócios, assim como ocorria no Canadá, cujo tipo de circulação monetária era apresentado por Simonsen como "o que melhor amparava as necessidades da producção de um paiz novo e agrícola". ${ }^{189}$

\footnotetext{
${ }^{186}$ AFTALION, 1927, p. 234-235.

${ }^{187}$ NENOVSKY, Nikolay. Exchange Rates and Inflation: France and Bulgaria in the Interwar Period and the Contribution of Albert Aftalion (1874-1956). Sofia: National Bank of Bulgaria, 2006. pp. 7-12. Segundo Nenovsky, Albert Aftalion (18741956) foi um economista de origem búlgara muito influente na academia francesa, durante o período entreguerras. Teria tido alguma influência em seu país de origem, a Bulgária, mas as traduções de suas obras do francês para o búlgaro eram escassas e sua influência intelectual tenderia a se enfraquecer após a Segunda Guerra.

${ }^{188}$ SIMONSEN, 1930, p. 18.

${ }^{189}$ SIMONSEN, 1930, p. 24
} 


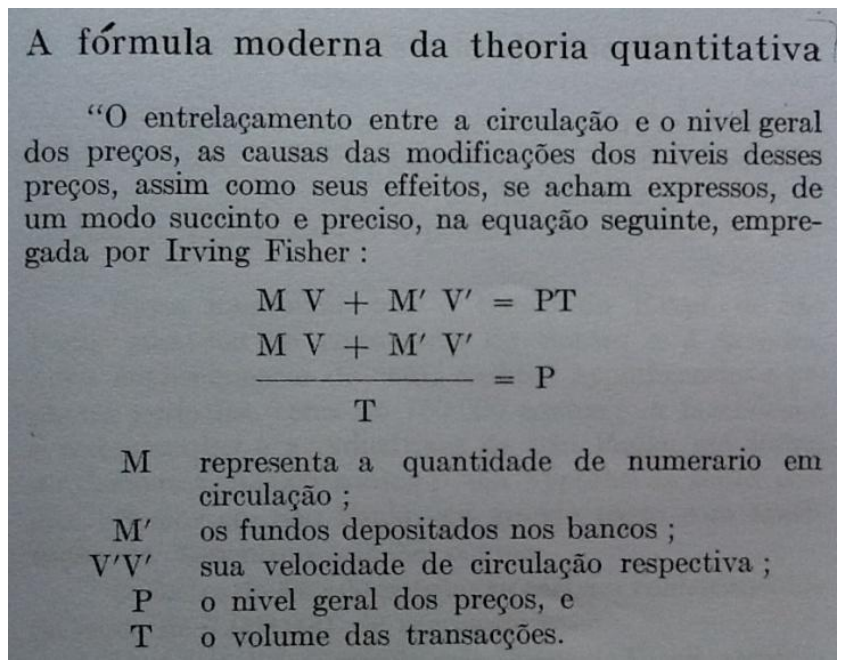

Figura 2. Formulação da teoria quantitativa da moeda. Fonte: SIMONSEN, 1930, p. 25.

Como se pode perceber na Figura 2, a partir de uma formulação bem simples da equação quantitativa da moeda, que Simonsen afirmava ter sido empregada por Irving Fisher, foram retiradas algumas conclusões dignas de interesse. "No Brasil, neste momento, assistimos á contracção da massa do numerario $\mathrm{M}$ em circulação; a velocidade da circulação $\mathrm{V}$ está diminuindo em consequencia do factor desconfiança; o mesmo se dá com M' e V'. O volume de transações T está obrigatoriamente augmentando pela super-producção do café." ${ }^{190}$. Havendo, portanto, redução em todos os termos do numerador e aumento em $\mathrm{T}$, o numerador, o resultado seria uma diminuição de P, o nível de preços. Simonsen atribui a queda na velocidade de circulação da moeda (V) e dos depósitos (V') ao aumento do fator desconfiança - isso evidencia a busca por aplicar, sem muita preocupação com a elegância acadêmica, uma formulação teórica que ajudasse a compreender a situação imediata que o Brasil atravessava. Simonsen estabeleceu, por meio de uma aplicação da teoria quantitativa, um nexo entre a política monetária restritiva em curso, que criticava, e um processo deflacionário. Essas medidas austeras tinham como principal responsável, para Simonsen, o Banco do Brasil, que vinha adotando uma política de defesa do valor da moeda, por meio do aumento de seus encaixes, isto é, por meio da redução do numerário circulante. ${ }^{191}$

Vale ressaltar aqui o hibridismo das referências intelectuais de Simonsen: ainda que estivesse sintonizado com o que se publicava na Europa, Simonsen não aderia de forma definitiva a uma escola ou vertente de pensamento específica. A questão da teoria monetária é um exemplo. Como vimos, a teoria da moeda proposta por Aftalion era justamente um questionamento da noção de que a quantidade de moeda em circulação é o primeiro

\footnotetext{
${ }^{190}$ SIMONSEN, 1930, pp. 25-26.

${ }^{191}$ SIMONSEN, 1930, p. 21.
} 
determinante dos preços. A apropriação feita por Simonsen da teoria quantitativa, ao contrário, estabelecia um nexo causal claro entre a contração do numerário circulante, colocada em prática pelo Banco do Brasil, e a deflação. Para estudar as causas da crise, o argumento de Aftalion era válido - mas não toda a teoria econômica deste autor. Para fazer a crítica da austeridade monetária do Banco do Brasil, Simonsen valia-se da teoria quantitativa, numa formulação que associava a Fisher, sem também discutir outras implicações das formulações teóricas deste autor. Nesse sentido, pode-se dizer que a busca por formulações teóricas era constante na obra de Simonsen, já no final dos anos 1920 e início dos anos 1930. Não havia, contudo, aprofundamento numa linha teórica específica: havia uma procura, caso a caso, por explicações teóricas dos fenômenos econômicos.

A partir do estudo mais detido dos textos de Simonsen, há que rever a ideia, apresentada por Bielschowsky, de que a produção intelectual de Simonsen em economia repousaria sobre um "vazio teórico", pois Simonsen "não viveu a fértil década de elaboração da chamada 'economia do subdesenvolvimento' e que trouxe para a América Latina a resposta analítica da Cepal às proposições teóricas e práticas do liberalismo econômico". ${ }^{192}$ Essa argumentação tem um elemento de anacronismo, pois avalia a elaboração de Simonsen a partir da resposta analítica cepalina, que viria quase duas décadas depois. Nesse sentido, esse tipo de raciocínio contribui pouco para o estudo da especificidade do pensamento de Simonsen: como vimos, havia, desde o início dos anos 1930, uma busca por referências teóricas, sem que houvesse a adesão a uma escola de pensamento única e o uso sistematizado das categorias teóricas.

A parte final do livro As crises no Brasil tem justamente este título e constitui um apanhado histórico das crises monetário-financeiras do Brasil, desde o início do século XIX até a crise coeva, iniciada em 1929. Talvez seja este o primeiro ensaio de história econômica publicado por Simonsen, abarcando um período amplo da história do Brasil, apresentando dados e fornecendo algum tipo de interpretação sobre os processos tratados. No caso, a interpretação era simples, exposta desde o início do texto: "Si temos sentido grandes depressões oriundas de poderosos factores externos que escaparam ao nosso controle, muitas vezes temos aggravado, com a nossa inepcia, a actuação desses mesmos factores. As maiores crises que temos experimentado foram, porém, devidas a falhas em nossa organização administrativa, pois que existe uma interdependência inilludivel entre a direção dos negocios publicos e o curso geral da economia privada". ${ }^{193}$ Embora numa perspectiva mais abrangente, está presente a ideia que norteara os escritos de Simonsen desde os anos 1910: a organização administrativa ou produtiva seria a chave dos problemas.

\footnotetext{
${ }^{192}$ Ver BIELSCHOWSKY, 2000, pp. 86-87.

${ }^{193}$ SIMONSEN, 1930, p. 31.
} 
A história monetária e financeira do século XIX era apresentada em consonância com esse tipo de leitura. Da "desmoralização" do primeiro Banco do Brasil, com a partida de D. João VI, que teria esvaziado os cofres do banco, até o encilhamento, o foco da interpretação recaía sobre a política econômica, sobre a forma pouco organizada de se lidar com os problemas econômicos. Simonsen mostrava-se crítico com relação a políticas emissionistas, como as da primeira década republicana, em que o governo "dava concessões, promulgava decretos sucessivos com a preocupação mais de demolir o passado do que de fazer o nosso progresso evoluir em marcha harmonica com seus factores reais" ${ }^{194}$. Também era reticente às medidas de cunho deflacionista e estabilizador aplicadas por Campos Sales, que teriam colocado em situação "penosa" as classes produtoras brasileiras. De forma geral, prevalecia a percepção de que as autoridades brasileiras teriam provocado, ou ao menos amplificado muito, as crises financeiras.

Para o Novecentos, houve uma mudança de interpretação. Do século XIX para o XX, teria mudado a natureza das crises no Brasil: "durante o século XIX, foram os factos politicos e actos administrativos que quasi sempre motivaram e aggravaram os estados de crise. (...) No presente seculo, em face da supremacia absoluta do café como producto de maior exportação, as crises do café constituem crises nacionaes (...)". ${ }^{195}$ Simonsen destacava, neste processo, uma mudança do eixo econômico do chamado "Norte" - Bahia e Pernambuco, produtores de açúcar, algodão e couros - para os estados produtores de café. As crises do café teriam sérias repercussões sobre a taxa de câmbio, gerando perturbações sobre um mau sistema circulatório e insuficiente aparelhamento bancário. Simonsen fez uma descrição breve das principais crises de preço do café, que foram seguidas pelas três valorizações do produto (1906, 1917 e 1921).

A forma de ver a crise como fenômeno regular e, ao mesmo tempo, dotado de características que se modificam ao longo do tempo estava presente em Ansiaux. Aftalion também se dedicou a estudar os ciclos econômicos e tendia a percebê-los como baseados em fatores reais da economia, mais do que em flutuações monetárias. ${ }^{196}$ Seu diagnóstico da crise de 1929, referido acima, como crise de superprodução e não resultante de fatores monetários, mostra esse tipo de tendência. Essa abordagem cíclica da história econômica, por parte dos economistas, não era restrita a esses autores, pelo contrário. Pode-se pensar mesmo num ambiente intelectual favorável a esse tipo de abordagem: na Europa, o número de crises e sua periodicidade haviam-se tornado mais pronunciados que anteriormente. Além disso, as

\footnotetext{
${ }^{194}$ SIMONSEN, 1930, p. 37.

${ }^{195}$ SIMONSEN, 1930, p. 38.

${ }^{196}$ NENOVSKY, 2006, p. 10
} 
análises estatísticas da dinâmica das variáveis econômicas tornaram-se mais frequentes, permitindo delimitar melhor as flutuações cíclicas e colocando esse tipo de abordagem em voga. $^{197}$

Esse esboço de uma abordagem histórica dos problemas econômicos brasileiros abria caminho para um tipo de procedimento que se tornaria frequente tanto nos trabalhos de Simonsen, quanto em seus discursos e participações parlamentares: fazer uma reconstrução histórica para dar sustentação a certos argumentos. Em As crises do Brasil, como se pôde ver, não havia uma interpretação bem definida para os entraves brasileiros, há sobretudo uma pluralidade de referências. Duas linhas de argumentação, no entanto, se destacavam: de um lado, a empregada para explicar as crises do século XIX e ligada à ideia da racionalização produtiva: era limitada a capacidade do Brasil de lidar com as crises, de pôr em prática políticas econômicas consistentes, devido, basicamente, à inépcia; de outro, a interpretação aplicada ao século XX: a dependência da economia brasileira com relação ao café fazia com que crises nas vendas desse produto se transformassem em crises nacionais. Como veremos, a interpretação que Simonsen construirá da história do Brasil, em seu livro de 1937, está mais na segunda direção.

\subsection{A Escola Livre de Sociologia e Política e a História econômica do Brasil}

O início dos anos 1930 foram marcados, na trajetória de Roberto Simonsen, pelo movimento constitucionalista em São Paulo, por sua atuação na Escola Livre de Sociologia e Política (ELSP) e por sua participação parlamentar, como representante dos industriais paulistas: foi deputado à Constituinte de 1933/34 e, depois, deputado na Câmara Federal, no interregno constitucional do governo Vargas. Durante a guerra civil em São Paulo, Simonsen contribuiu para a organização do Serviço de Cadastro Industrial, que fazia parte do esforço de mobilização do parque fabril de São Paulo para produzir munição e bens necessários ao abastecimento. ${ }^{198}$ Foi nomeado, como delegado da FIESP, para a Comissão Técnica de Material Bélico, e integrou o Conselho Consultivo Econômico-Financeiro, no âmbito do qual elaborou projeto para financiamento da lavoura e reforço ao Caixa de guerra. ${ }^{199}$

Em janeiro de 1932, Simonsen publicou, como já foi referido, a coletânea À margem da profissão. O prefácio a esta obra pode ser visto como uma espécie de síntese do pensamento do autor neste momento. Simonsen argumentava que, dada a deficiência de capitais e iniciativa particular no Brasil, os empreendimentos de engenharia tendem a ficar a cargo do

\footnotetext{
${ }^{197}$ NENOVSKY, 2006, p. 10.

${ }^{198}$ Folha da Manhã, 19/07/1932.

${ }^{199}$ Folha da Manhã, 29/07/1932, 23/08/1932, 03/09/1932.
} 
poder público. "Forçado assim a ter contato com essas administrações [públicas] fui frequentemente alvo da maledicencia e de ataques systematicos do espirito de demolição que se compraz, em nosso meio, a combater todo e qualquer empreendimento". 200

Ao longo do prefácio, Simonsen reforçava que procuraria tratar, sob um ponto de vista nacional, os principais problemas que atingiam o país. "Vemos, no entanto, brasileiros illustres subscrevendo theorias e doutrinas lançadas por povos que contando com forte apparelhamento commercial só têm vantagens na liberdade absoluta porque é por intermédio desta que elles dominam os mais fracos nos embates economicos internacionaes". ${ }^{201}$ Essa marcação de posição é constante, mas parece uma construção a posteriori: nem toda a produção de Simonsen teria, de fato, uma perspectiva nacionalista, como foi visto nos textos anos 1910 e 1920, em que as preocupações eram mais voltadas para o universo da unidade produtiva privada. Havia uma crítica à política de defesa do café e uma defesa enfática do protecionismo, com uma menção à "estafada discussão entre protecionismo e livrecambismo".

O livre-cambio traduz a liberdade de escambo entre nações o consequente predominio das mais fortes muitas vezes em detrimento dos interesses e do padrão de vida das menos apparelhadas. O proteccionismo cercea de alguma fórma e por algum tempo a permuta entre as nações, mas traduz uma grande liberdade de producção dentro das fronteiras do paiz que o adopta. ${ }^{202}$

Por fim, Simonsen formulou uma severa crítica ao comunismo russo: o Estado teria invertido a ordem das prioridades. Havia uma riqueza mínima nas mãos de poucos: ao se repartir essa riqueza para todos, a quota que cabe a cada um se tornava ínfima, levando à miséria geral. O correto, para Simonsen, seria aquilo que a Rússia estava empreendendo no momento: "esforço desesperado para a produção intensa de bens capazes de criar um forte poder aquisitivo para o povo russo"203. A ênfase de Simonsen estava na produção - e não na distribuição. Desse modo, Simonsen destaca a virtude do planejamento em elevar a produção nacional, mas não menciona a palavra planejamento, estruturando sua argumentação em torno da crítica ao comunismo. Convém reter, deste prefácio, três eixos principais, que não estiveram sempre presentes nos textos de Simonsen, mas que o autor apresenta como centrais, numa tentativa de dar coerência ao seu próprio pensamento até então. Esses três aspectos principais são o nacionalismo, o protecionismo/defesa da indústria nacional e a crítica ao comunismo, reconhecendo os méritos do planejamento.

Em 1933, Simonsen fundou, ao lado de outras personalidades da elite paulista, a Escola

\footnotetext{
${ }^{200}$ SIMONSEN, Roberto. "Explicando" [1932]. IN: MP, pp. 7-10.

${ }^{201}$ SIMONSEN, 1932, p. 8.

${ }^{202}$ SIMONSEN, 1932, p. 9.

${ }^{203}$ SIMONSEN, 1932, p. 9.
} 
Livre de Sociologia e Política, em São Paulo, onde seria professor da cadeira de História Econômica do Brasil. A fundação dessa instituição se relaciona com alguns dos eventos mencionados até aqui: findos os conflitos de 1932, os paulistas viam-se diante do desafio se articular para participar da nova realidade do país, exercendo um papel político e intelectual à altura da importância econômica de São Paulo. A ELSP nascera com o objetivo de formar quadros técnicos, veiculando um ensino mais prático, com um projeto, em certa medida, oposto ao da Faculdade de Filosofia, Ciências e Letras, que viria a ser o centro da Universidade de São Paulo. O projeto desta última instituição era mais voltado para a investigação intelectual e teórica. Os profissionais formados pela ELSP teriam, acima de tudo, a função de ajudar a tocar os "negócios do Estado", tendo em vista que as tendências políticas do momento apontavam para a negação do Estado liberal e, por conseguinte, do aumento das funções do Estado intervencionista. ${ }^{204}$

Esse perfil técnico e prático fica claro quando se tem em conta a maciça presença de engenheiros na ELSP: dos 104 signatários do manifesto de fundação, 50 eram engenheiros, sugerindo uma proximidade com o Instituto de Organização Racional do Trabalho (IDORT), criado em 1932, com o objetivo de desenvolver estudos sobre organização geral da produção, orientação profissional e higiene do trabalho. De fato, constam das assinaturas do Manifesto de Fundação da ELSP alguns engenheiros que também participaram da fundação do IDORT. Entre eles, vale destacar: Roberto Simonsen, naquele momento presidente do Instituto de Engenharia de São Paulo e diretor da FIESP; Armando Salles Oliveira, presidente do IDORT e Octávio Pupo Nogueira, Secretário-Geral da FIESP. Também participou da fundação da ELSP, mas não do IDORT, o diretor da Escola Politécnica de São Paulo, Carlos Gomes de Souza Shalders. ${ }^{205}$ Essa proximidade entre ELSP e engenheiros ligados à indústria se daria, segundo Marina C. Vaz Silva, em torno da ideia de racionalização, a ser ampliada da esfera da produção para a vida cultural, social e política. ${ }^{206}$

De acordo com Silva, o projeto pedagógico da ELSP seria o resultado da influência de três grupos intelectuais da elite paulista: os já mencionados engenheiros, ligados ao IDORT e formuladores do que a autora denomina uma "pedagogia do industrialismo", os educadores vinculados ao movimento escolanovista e os modernistas que se articularam em torno do recém-fundado Departamento de Cultura do Município de São Paulo. Esses grupos se uniam

\footnotetext{
${ }^{204}$ LIMONGI, Fernando. “A Escola Livre de Sociologia e Polítca em São Paulo”. IN: MICELI, Sérgio. História das ciências sociais no Brasil. São Paulo: Vértice/IDESP, 1989, pp. 218-219.

${ }^{205}$ Informações e Programas (1933-34). Arquivo do CEDOC/ELSP. O cruzamento com os dados da fundação do IDORT é feito por Marina C. V. Silva.

206 SILVA, Marina Correia Vaz. Da maria-fumaça à fumaça das fábricas - a ELSP de São Paulo. São Paulo: Faculdade de Educação/USP, 1994. Tese de Doutorado. p. 21.
} 
na defesa de uma política educacional tendo em vista uma civilização urbana e industrial, que tinha de lidar com a fábrica, com o operário - e com a manutenção do controle social da elite dirigente sobre essa sociedade capitalista industrial que se formava. $\mathrm{O}$ rompimento com o atraso nacional se daria por meio da racionalização. ${ }^{207}$

Nesse sentido, a ELSP tinha a pretensão de produzir e transmitir um conhecimento renovado, que, segundo Fábio Maza, seria norteado por uma concepção prática e utilitária, forjadora de um projeto modernizador para o Brasil e centrada num tipo de ciência voltada para a compreensão dos mecanismos da sociedade que se queria reformar. ${ }^{208}$ Vale lembrar que o ano é 1933 e Simonsen mencionou, em discurso na cerimônia de fundação da ELSP, os grandes ganhos obtidos por meio da cooperação e organização técnicas durante o movimento constitucionalista de 1932. A elite paulista, pela qual e para a qual fora criada a ELSP, estava imbuída desse espírito de criar quadros que permitissem uma atuação mais efetiva, no âmbito administrativo e político, como fica claro a partir do trecho abaixo, extraído do referido Manifesto de Fundação da ELSP.

\begin{abstract}
Ainda ha pouco, na guerra civil desencadeada em nosso Estado, e tambem agora, na luta para refazer-se dos effeitos dessa guerra e das afflicções que a antecederam, o povo sente-se mais ou menos às tontas e vacillante. Quer agir, tem vontade de promover algo de util, cogita de uma renovação benefica, mas não encontra a mola central de uma elite harmoniosa, que lhe inspira confiança, que lhe ensine passos firmes e seguros. ${ }^{209}$
\end{abstract}

No discurso pronunciado por ocasião da fundação da ELSP, 1933, Simonsen afirmava que a história não se modifica violentamente: "Os costumes e os habitos dos povos só podem ser modificados pela acção lenta do tempo". ${ }^{210} \mathrm{O}$ idealismo de um Robespierre é claramente descartado como estratégia de mudança social, devendo prevalecer o progresso gradual, entendido como "a continua e harmonica conciliação do homem com a sociedade". O meio para se alcançar esse objetivo seria o predomínio da técnica como forma de organização da sociedade, isto é, a tecnocracia. A ELSP viria, portanto, suprir a lacuna, no meio universitário brasileiro, de cursos que capacitassem os profissionais "a uma efficiente atuação na vida social". ${ }^{211}$

O discurso de Simonsen, publicado pelo jornal "O Diário de São Paulo" em 28 de maio de 1933 e posteriormente pelo próprio autor em brochura, conforme citado, foi uma tentativa de dialogar com as ciências sociais, em especial com a sociologia. A concepção que Simonsen

\footnotetext{
${ }^{207}$ SILVA, 1994, pp. 43-44.

${ }^{208}$ MAZA, 2004, p. 57.

${ }^{209}$ Informações e Programas (1933-34). Arquivo do CEDOC/ELSP. O Manifesto também foi publicado na Folha da Manhã, em 28/05/1933, o dia seguinte à sua assinatura.

${ }^{210}$ SIMONSEN, Roberto. Rumo à verdade. São Paulo: São Paulo Editora, 1933, p. 25.

${ }^{211}$ SIMONSEN, 1933, p. 27.
} 
tinha de sociologia é difícil de ser identificada, pois são referidos autores de perspectivas teóricas distintas, desde Vico e Hume, passando por Montesquieu, Voltaire, Saint-Simon, Kant e Adam Smith, até Le Play e Comte. De forma geral, Simonsen valorizava o método, a experiência e via a sociologia como forma de intervir diretamente na realidade. ${ }^{212} \mathrm{O}$ método que deveria prevalecer, como tendência a ser adotada pela sociologia, seria o das ciências naturais: "os methodos de observação e analyse cuidadosamente contrôlados". ${ }^{213}$ Para Simonsen, o conhecimento deveria passar da fase das abstrações e generalidades para a fase da ciência, e desta para uma terceira etapa - a da técnica - em que a ciência se aplica, objetivamente. $^{214}$

É com esta ótica que Simonsen menciona a obra do economista alemão Friedrich List, que teria contribuído para que a economia política perdesse parte do seu caráter puramente acadêmico. Ao introduzir a "economia nacional", List teria mostrado como o Estado atua na conduta dos indivíduos, por meio de suas leis e de sua política externa. "O conceito de vida nacional teve uma influencia decisiva no desenvolvimento da economia politica e na applicação do methodo comparativo na historia da economica; os typos abstractos com que se detinha a velha economia politica passaram a ser substituidos por tipos mais concretos" ${ }^{215}$ No discurso de fundação da ELSP, a ênfase é no tipo de abordagem das ciências sociais a ser veiculado pela Escola: seria, como foi visto, uma abordagem ligada a uma pluralidade de autores, mas que se definia pela passagem do método generalista para o método objetivo e pela ênfase na aplicação. Vale notar que para a economia política, essa passagem do generalismo acadêmico ou bacharelismo à ciência corresponderia, na concepção de Simonsen, à introdução da nação como categoria de análise principal, daí o mérito conferido a Friedrich List.

Ainda no âmbito da economia, Simonsen citou outro autor, H. O. Chalkley ${ }^{216}$, para reconstituir um círculo vicioso de influências econômicas, que mostrava quais fatores econômicos levavam ao mal-estar generalizado que poderia conduzir as nações a um estado de guerra: vale lembrar que, na Europa, o período era crítico, com o fascismo italiano no poder desde os anos 1920 e Hitler oficialmente conduzido à liderança do governo alemão em 1933. A ideia básica é que o cenário de recessão econômica leva à queda nos preços e a uma série de eventos correlacionados - depreciação da moeda, tarifas, restrições de produção,

\footnotetext{
${ }^{212}$ MAZA, 2004, p. 20.

${ }^{213}$ SIMONSEN, 1933, p. 19.

${ }^{214}$ SIMONSEN, 1933, p. 20.

${ }^{215}$ SIMONSEN, 1933,

${ }^{216}$ As poucas informações que conseguimos sobre este autor permitem afirmar que se tratou de um economista e diplomata britânico que foi Conselheiro Comercial na Argentina de 1916 a 1931. Ver MACKIE, Colin. "A directory of British diplomats. 1900-2011”. Disponível em: < http://www.gulabin.com/ >. Acesso em: 26/08/2013.
} 
infração dos contratos, perda de confiança nos negócios - que conduzem à desocupação geral e ao aumento de impostos. Isso, por sua vez, gera quedas de governo, revoluções e desordem, fazendo surgir o estado de guerra. O esquema de Chalkley foi reproduzido na Folha da Manhã, como se segue:

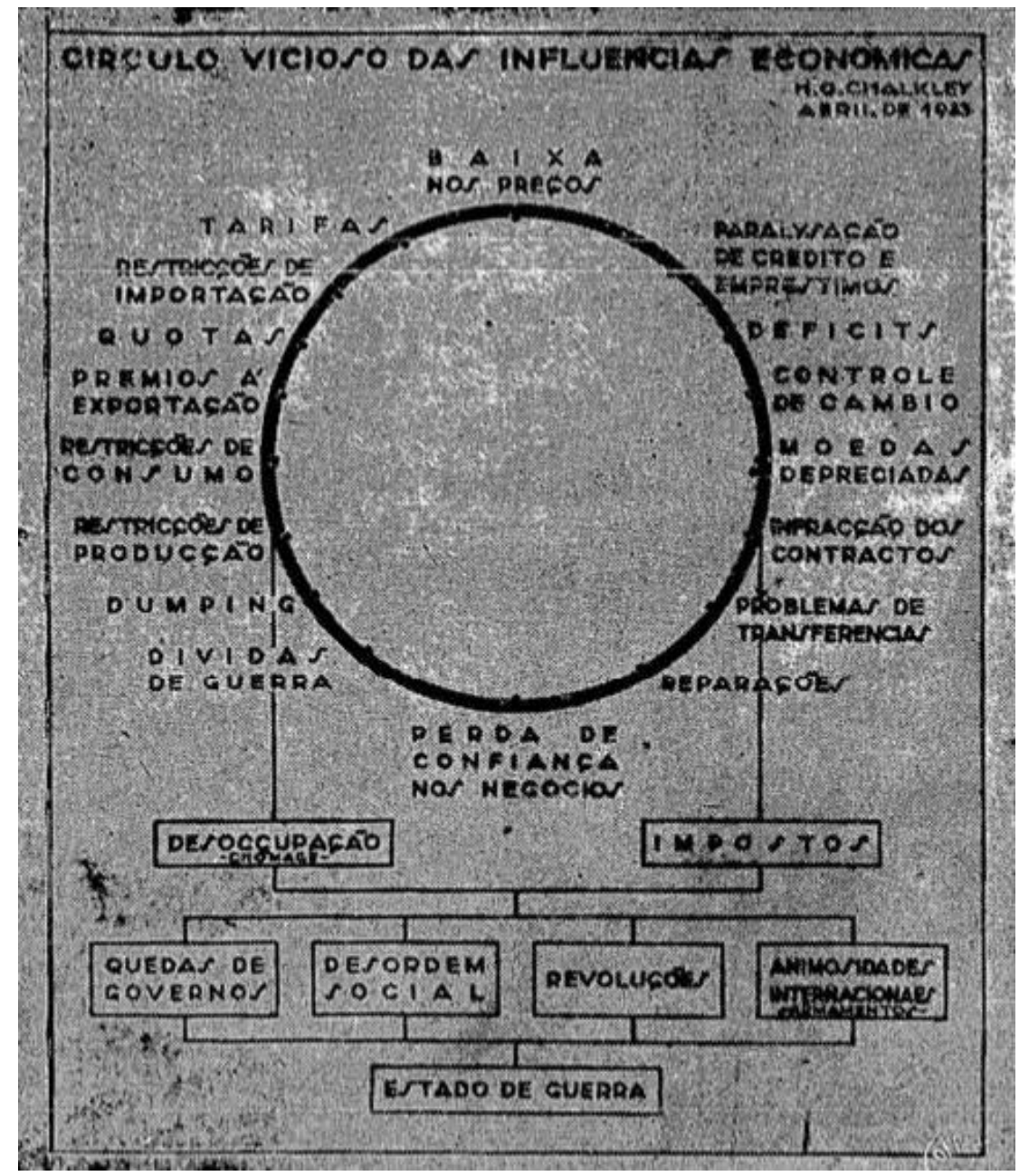

Figura 3. Esquema de Chalkley. Fonte: Folha da Manhã, 28/05/1933.

Simonsen atribuía, em seu discurso, grande importância a Friedrich List, considerado o pai do protecionismo econômico, e fez referência a um esquema de explicação das relações entre fatores econômicos e eventos políticos aparentemente baseado em ideias ligadas ao livre-comércio: neste esquema, medidas protecionistas, tais como quotas, tarifas e restrições à importação de forma geral são avaliadas como totalmente nocivas e conducentes à guerra. Como veremos mais adiante, Simonsen elaborou a questão da teoria do comércio internacional em outros textos - e se inclinava por uma adesão às teorias protecionistas de List e Manoilescu. Vale observar, todavia, a pluralidade de autores e referências teóricas, que não permite que se filie Simonsen a uma escola de pensamento econômico específica. A referência ao esquema de Chalkley, em todo caso, parece estar mais relacionada aos objetivos 
da ELSP do que à concepção de economia por trás da explicação fornecida: Simonsen concluiu esta parte do discurso com o seguinte: "Constata-se assim o formidavel entrelaçamento dos maiores problemas de ordem economica, politica e social, com que a humanidade já deparou e que se impõem á solução contemporanea. Teremos homens de preparo á altura de encaral-os e resolvel-os?” Os problemas sociais são vistos por Simonsen como entrelaçados aos econômicos - e ambos devem ser evitados por meio do uso racional da técnica, que, como foi visto, é a aplicação à realidade dos princípios da ciência. Nos termos colocados por Marina C. V. Silva, acima, trata-se de um projeto pedagógico voltado para a resolução desses problemas ou entraves econômicos e sociais por meio da formação de uma elite dirigente capaz de lidar com essas questões, por meio de métodos racionais, mantendo a trajetória de desenvolvimento da sociedade sob o seu controle.

O curso "História Econômica do Brasil" foi ministrado pela primeira vez em 1936, na ELSP, como constam das anotações de aula preparadas para o curso dado por Roberto Simonsen. A disciplina era parte integrante do currículo do curso de "Bacharelado em Ciências Políticas e Sociais", ministrado na ELSP, de 1936 a 1952. O último programa de disciplina remanescente, no qual consta o nome de Simonsen como ministrante da referida cadeira, data de 1941. Como há lacunas nesses programas, não foi possível precisar até que ano Simonsen de fato ministrou as aulas. Certo é que seu programa foi reformulado na década de 1950: em 1952, a disciplina foi dividida em História Econômica do Brasil I (equivalente à Colônia) e História Econômica do Brasil II (equivalente aos períodos imperial e republicano). ${ }^{217} \mathrm{O}$ programa da disciplina ministrada por Roberto Simonsen, que consta dos registros da ELSP, abarcava os períodos colonial, imperial e republicano da história do Brasil, fechando-se não com o período joanino e a autonomia política, como o livro $H E B$, mas com dois tópicos sugestivos do clima intelectual da fundação da ELSP: "A evolução econômica dos países americanos: as razões de sua diferenciação" e "O Brasil em face da economia mundial. São Paulo na Federação". 218

O programa, nesta forma inicial, foi publicado pelo jornal "O Diário de São Paulo", quatro dias depois da "preleção inaugural" de Roberto Simonsen, a qual abriu o terceiro ano letivo da ELSP. ${ }^{219}$ Não constam anotações de aula de Simonsen para além do período histórico abordado em seu livro (a Colônia) - o que leva a crer que a publicação do livro foi fiel ao plano de aulas elaborado pelo autor, com exceção de algumas alterações na

\footnotetext{
${ }^{217}$ Currículos do curso de bacharelado em Ciências Políticas e Sociais. Arquivo do CEDOC/ELSP.

${ }^{218}$ Programas de disciplinas. Arquivo do CEDOC/ELSP.

${ }^{219}$ Diário de São Paulo, 12/04/1936. Dossiê Roberto Simonsen. Arquivo do CEDOC/ELSP.
} 
organização formal dos capítulos referentes à mineração e à pecuária. ${ }^{220}$ Conforme consta de informe divulgado pela ELSP no jornal "A Gazeta", em 1935 Simonsen já fazia parte do corpo docente da Escola antes de iniciar o curso em 1936, figurando como professor catedrático de "Economia Brasileira". Simonsen também fazia parte dos "Fundadores do patrimonio e Protectores" da ELSP. ${ }^{221}$

Em consonância com esse ambiente intelectual da ELSP, voltado para a formação de quadros de elite capacitados, com vistas a atuar no âmbito do Estado e a lidar com os desafios colocados pela modernização, o objetivo do estudo da história econômica é expresso no primeiro capítulo do livro História econômica do Brasil, equivalente à aula inaugural do curso de História Econômica do Brasil, ministrada por Simonsen em 8 de abril de 1936.

\begin{abstract}
A um estudioso sincero de nossas questões econômicas uma conclusão, porém, desde logo se impõe: os povos que hoje se contam na vanguarda do progresso e da civilização libertaram-se, nos tempos modernos, de uma desorganização que os estiolava; e a primeira manifestação de sua força foi a fixação de uma consciência nacional de suas próprias aspirações e necessidades. ${ }^{222}$
\end{abstract}

O projeto dessa elite, ligada ao setor industrial e também vinculada a movimentos de reforma educacional e cultural, é associado aos destinos da nação. A perspectiva nacionalista adotada por Simonsen associa a racionalização - a libertação da "desorganização que estiolava" - ao progresso dos povos. Trata-se de um nacionalismo específico e voltado para um objetivo: seria necessário fixar uma consciência nacional para superar esse estágio de atraso e desorganização em que se encontrava o Brasil. É a partir dessa ideia de uma perspectiva nacionalista ligada aos interesses da classe dos industriais e de setores reformistas da elite paulista que se pretende fazer uma leitura mais detida do livro História econômica do Brasil.

Com o objetivo de estudar melhor esta obra seminal em nossa historiografia econômica, apresenta-se, abaixo, um "Roteiro de leitura", que resume o livro e propõe uma organização e uma interpretação de seu conteúdo, ao mesmo tempo que busca organizar as fontes e referências usadas por Simonsen na confecção de seu texto.

\title{
2.2.1. Roteiro de leitura
}

Esta tentativa de síntese do livro História econômica do Brasil parte da ideia de que a interpretação que Simonsen formula para a história do Brasil é indissociável dos seus escritos mais estritamente econômicos. Com exceção do estudo comparativo de Flávio Saes, sobre Roberto Simonsen e Celso Furtado, os estudos que lidam com o pensamento de Simonsen em

\footnotetext{
${ }^{220}$ Anotações de aula. Dossiê Roberto Simonsen. Arquivo do CEDOC/ELSP.

${ }^{221}$ A Gazeta, 07/04/1935. Dossiê Roberto Simonsen. Arquivo do CEDOC/ELSP.

${ }^{222}$ HEB, p. 34.
} 
particular não integram, ou incluem apenas marginalmente na análise do pensamento econômico, a dimensão historiográfica de sua obra. ${ }^{223}$ Do ponto de vista da historiografia econômica, os estudos procuraram avançar com relação à interpretação de Simonsen, sem, no entanto, buscar situá-la em seu próprio tempo. ${ }^{224}$ Como procuraremos mostrar, a chave interpretativa de Simonsen para a história do Brasil está ligada ao seu projeto político e dá suporte à sua argumentação mais puramente econômica, estruturada em torno do protecionismo e do planejamento.

O projeto político de Simonsen era a industrialização. Sua interpretação da história, como se verá, se baseia na abordagem dos ciclos de produtos de exportação: como Colônia, o Brasil nasceu fornecendo gêneros primários à metrópole e, depois, ao mercado internacional. Enquanto o produto-rei - açúcar, ouro, café - encontrasse boa colocação no mercado internacional, acumulava-se riqueza rapidamente. Da mesma forma, essa riqueza acumulada era dilapidada quando os preços do produto exportado se deprimissem, sendo necessário buscar um novo produto e correr os mesmos riscos da sujeição às flutuações do mercado internacional. A riqueza gerada pelos ciclos primário-exportadores, ou ciclos da economia colonial, não era permanente. Ora, a solução para essa situação não poderia passar por mais ciclos sucessivos de exportação de gêneros primários: a atividade que legaria recursos permanentemente ao país seria a indústria, voltada para o mercado interno e, portanto, menos sujeita às oscilações exógenas do que as atividades exclusivamente voltadas para a exportação. Ao longo de seu livro, Simonsen concedeu lugar de destaque a políticas de fomento às manufaturas como as do Marquês de Pombal e de D. João VI. No caso de Pombal, a avaliação positiva se referia ao fato de este ter fomentado as "formas estáveis de enriquecimento", em Portugal, por meio das manufaturas. Nesse sentido, a interpretação de Simonsen para a história econômica é coerente com seu projeto político.

Sobre o vínculo da interpretação histórica de Simonsen com seu tratamento de questões mais puramente econômicas, como protecionismo comercial e planejamento estatal, vale adiantar que, do ponto de vista do método, uma abordagem histórica abre espaço para teorias protecionistas e propostas de intervenção estatal na economia, de modo a mudar os rumos do desenvolvimento econômico. Isso porque ao se compreender que a inserção internacional do Brasil, como produtor de matérias-primas, não se dava por causa de uma vocação agrária

\footnotetext{
${ }^{223}$ Ver os trabalhos: FANGANIELLO, 1970; CEPÊDA, 2003; MAZA, 2004 e SAES, 2009.

224 A História econômica do Brasil (1945), de Caio Prado Jr., traz HEB e Evolução industrial do Brasil, de Simonsen como referências bibliográficas. Celso Furtado cita $H E B$ diversas vezes em Formação econômica do Brasil (1959). Fernando Novais, em sua tese defendida em 1973, Portugal e o Brasil na crise do Antigo Sistema Colonial (1777-1808), cita HEB. O trabalho de João Fragoso e Manolo Florentino, O arcaísmo como projeto, publicado pela primeira vez em 1993, não cita $H E B$, mas inicia a revisão historiográfica com o argumento de que Caio Prado Jr. teria avançando em relação à "teoria dos ciclos".
} 
determinada por dotações naturais, mas, sim, como parte de um processo histórico que tinha suas raízes na colonização, seria possível mudar o curso desse processo. Essa mudança viria por meio de políticas deliberadas de industrialização, consubstanciadas na proteção à indústria nacional e na intervenção estatal planejada. Nessa perspectiva, a obra histórica de Simonsen é fundamental para seu pensamento econômico - e vale estudá-la como parte dele. As elaborações de Simonsen ao longo da controvérsia do planejamento, por exemplo, são uma confirmação importante deste argumento.

A divisão da obra em três "Partes", como está proposto no roteiro não é de Simonsen: é apenas uma sugestão de organização, que ficará mais clara ao longo do texto. A "Parte I" abrange os capítulos que Simonsen dedicou à economia colonial, isto é, aos núcleos produtores de gêneros voltados para o abastecimento direto do mercado externo, por intermédio da metrópole portuguesa. A "Parte II" seria dedicada a responder uma questão fundamental para Simonsen e para a historiografia brasileira: se a economia colonial era formada por núcleos dispersos, fornecedores de gêneros ao mercado externo e não voltados para a Colônia em si, por que a América portuguesa manteve-se politicamente unida? Simonsen busca, nos capítulos da "Parte II", os fatores econômicos que teriam urdido a "trama" que uniu o Brasil. Por fim, a Parte III - os capítulos finais - seria um balanço da colonização portuguesa e das questões levantadas pela independência política.

As notas que se iniciam com HEB referem-se ao livro História econômica do Brasil, em sua oitava edição, de 1978, pela Companhia Editora Nacional. A sigla CRS significa Coleção Roberto Simonsen. Muitas das vezes, Simonsen fazia citações imprecisas das fontes que utilizava: por meio do cruzamento das referências dadas em $H E B$ com as informações do acervo da Coleção, foi possível determinar, em alguns casos, quais obras Simonsen efetivamente teria consultado. O ANEXO 1 ao trabalho traz uma tabela contendo todas as obras citadas por Simonsen em seu livro, com os dados que foi possível reunir sobre suas datas de publicação e local de edição.

\section{Parte 1: História econômica e o significado econômico da colonização}

A disciplina de história econômica é apresentada, no capítulo I, ${ }^{225}$ como relativamente recente, sendo poucas as cadeiras dessa matéria, mesmo em países como Inglaterra e Estados Unidos. Estudiosos brasileiros também são raros, sendo citados os seguintes: Varnhagen, Capistrano de Abreu, Vieira Souto, Amaro Cavalcanti, Calógeras, este último muito elogiado. Estudiosos estrangeiros citados: Cunningham (Inglaterra); Schmoller e Knapp (Alemanha) e

\footnotetext{
${ }^{225}$ O capítulo I, “Introdução, antecedentes”, refere-se à aula ministrada em 8 de abril de 1936.
} 
Fustel de Coulanges (França). Marx é citado, pelas "críticas apaixonadas sobre o capitalismo".

$\mathrm{O}$ advento da modernidade, a partir do século $\mathrm{XV}$, é visto como resultante de vários fatores, como o enriquecimento das cidades italianas, a reforma religiosa e a descoberta da imprensa. O espírito guerreiro-religioso dos tempos medievais é substituído pelo espírito mercantil. Simonsen vê no feudalismo um entrave à expansão econômica, liberado pela irrupção da modernidade e da revolução comercial, que foi caracterizada pela navegação oceânica (não mais costeira), capitaneada, sucessivamente, por Portugal, Espanha, Holanda e Inglaterra. A mentalidade mercantil, numa época em que as maquinarias e aperfeiçoamentos técnicos limitavam a produção "à área de seus solos", levou à preocupação-chave do mercantilismo: o acúmulo de saldos em metais preciosos, necessários para liquidar trocas e conduzir guerras. Esse tipo de preocupação só veio a ser superado com a revolução industrial, no século XVIII, que permitiu que a produção e o consumo se elevassem muito, em relação ao meio circulante. A partir daí, surgiram novas preocupações e novas doutrinas, vistas por Simonsen como efeitos - e não como causas - dos fenômenos econômicos. Simonsen usa Sombart para diferenciar a mentalidade econômica da Idade Média - produzir para consumo imediato e necessidades mínimas - do pensamento dominante na "era capitalista": o aumento, sempre ascendente, da posse de riquezas.

Esse curto preâmbulo sobre a origem do capitalismo tem a função, no livro $H E B$, de associar a descoberta e colonização do Brasil à evolução do capitalismo no mundo. As políticas coloniais adotadas no Novo Mundo - busca de metais preciosos, produção de algodão, cultura da cana, etc. - são frutos desse sistema capitalista e "ainda hoje atuam de modo inequívoco em nossa evolução". ${ }^{226}$ Nas diversas regiões americanas, houve formas distintas de ocupação e colonização, condicionadas por fatores naturais e sociais: no Brasil, não havia metais disponíveis, sendo os portugueses "forçados" a recorrer à agricultura.

O objetivo do curso aberto por esta aula inaugural seria, para Simonsen, entender a história de um país que nasce atrelado ao exterior, com suas instituições econômicas "tomadas de empréstimo a outros povos". ${ }^{227} \mathrm{O}$ esforço do curso se daria no sentido de investigar "a origem dos muitos entraves que dificultaram e dificultam a nossa evolução progressista”. Já se pode inferir, desse preâmbulo, que esta origem estaria na especificidade da evolução econômica do Brasil, que nasce, conforme Simonsen, como colônia engatada ao capitalismo que se desenvolvia.

${ }^{226}$ HEB, p. 33.
${ }^{227}$ HEB, p. 34 
O segundo capítulo ${ }^{228}$ inicia-se com as navegações portuguesas, que teriam sido impulsionadas pela unificação monárquica do Estado, aliada à posição geográfica-política do país: o marco da vitória do "mar" sobre a "terra", em Portugal, teria sido a Revolução de Avis. As conquistas marítimas, começando pela conquista de Ceuta em 1415, foram-se estendendo ao longo do périplo africano até que Vasco da Gama chegou às Índias em 1497. Esta época de grandeza do comércio português correspondente, grosso modo, ao século XV é chamada por Simonsen, tendo como referência João Lúcio de Azevedo, de ciclo da pimenta. Este ciclo se finda, segundo Azevedo, com a perda, por parte de Portugal, da primazia comercial, detida a partir de então pelos Países Baixos, independentes da Espanha. Segue-se ao ciclo da pimenta o ciclo do açúcar, baseado na produção brasileira do século XVII, e a este sucede o ciclo do ouro, baseado na vultosa extração brasileira do século XVIII. Simonsen propõe, a partir dessa moldura de Lúcio de Azevedo, a abordagem a ser seguida no curso que ministrava: "Essas fases serão examinadas em conjunto com as etapas correspondentes da economia brasileira". 229

A interpretação de João Lúcio de Azevedo ${ }^{230}$, em Épocas de Portugal económico, cuja primeira edição é de 1928, baseia-se numa divisão da história do "Portugal absolutista" (da formação do Estado a 1842) em cinco fases ou ciclos, que correspondem aos capítulos de seu livro: monarquia agrária, ciclo da pimenta da Índia, primeiro ciclo do ouro, ciclo do açúcar e idade do ouro e diamantes. Em cada um desses ciclos, enfatiza-se o caráter pouco duradouro da riqueza gerada - e o fato de Portugal pouco ter-se aproveitado, por má administração ou por deixar-se levar pelo aparente gigantismo de seu império colonial, das riquezas geradas pelas conquistas. Sobre a fase declinante do açúcar brasileiro, na segunda metade do século XVIII, diz Azevedo:

Sucedera porém que desde muito a actividade da colónia e a atenção dos governantes se tinham desviado para outro rumo [o ouro das Minas Gerais]. O açúcar deixara de ser a riqueza por excelência da terra, e a fonte principal de riquezas para o Estado. Assim como a pimenta perdera a primazia em seu tempo, assim o açúcar veio a perdê-la também. Eram quase decorridos cem anos desde que o segundo ciclo do oiro se anunciara, e este realizara totalmente as promessas de origem. Com proveito da colónia e em geral da nação? De modo nenhum, como se descobriu, quando a febre que invadira os ânimos declinou, declinando também a produção. $^{231}$

Tanto o açúcar quanto o ouro do "segundo ciclo" - o ouro brasileiro (em oposição ao africano) - tiveram este caráter de riqueza efêmera. É marcante também a ideia de que, a

\footnotetext{
${ }^{228}$ O capítulo II, "Fases econômicas de Portugal e Espanha", refere-se à aula de 17 de abril de 1936.

${ }^{229}$ HEB, p. 41.

${ }^{230}$ João Lúcio de Azevedo nasceu em 1855, em Sintra (Portugal), vindo a falecer na mesma cidade, em 1933. Viveu em Belém (PA) e em Paris, tendo retornado a Portugal posteriormente.

${ }^{231}$ AZEVEDO, João Lúcio de. Épocas de Portugal económico. [1928]. 4ª edição. Porto: Imprensa Portuguesa, 1978.p. 269.
} 
prevalecer um novo ciclo, não só a atividade econômica, mas, também, a atenção dos governantes e, em última análise o próprio Estado, passa a articular-se em torno do novo produto-rei. Se o ouro fora um brilho passageiro, a economia diamantífera não teria melhor sorte: "Tão pouco o achado dos diamantes, riqueza mais rara que o oiro, trouxe prosperidade e maior ventura aos moradores das Minas". 232

De forma geral, a abordagem de Lúcio de Azevedo é crítica do atraso português, motivado, segundo o autor, pelo próprio caráter da gente lusa, pouco habituada ao trabalho requerido pela indústria. A presença britânica em Portugal também era alvo das críticas de Azevedo, pois teria contribuído para agravar esse atraso, mas não seria sua causa fundamental. O Tratado de Methuen, nesse sentido, era eximido da culpa pelo atraso industrial vivido por Portugal: em 1703, ano de sua ratificação, não haveria, segundo Lúcio de Azevedo, manufaturas a erradicar, já que as mesmas eram inexistentes em Portugal.

\footnotetext{
O problema económico de Portugal não era o das indústrias; sim outro mais complexo, e com raízes profundas no próprio ser da nacionalidade: administração ineficiente; um império colonial desproporcionado, pela extensão, aos meios possíveis de o povoar, explorar e defender; a condição da gente, inclinada a mais dela à vida aventurosa, e habituada aos ganhos depredatórios, aos fáceis empreendimentos de um ânimo afoito, mais do que ao trabalho monótono e lento, à constância na aplicação que as indústrias demandam. ${ }^{233}$
}

A temática que perpassa o texto de João Lúcio de Azevedo é o atraso português: o autor busca as razões econômicas desse atraso e, como o trecho acima explicita, a razão parece estar na formação histórica do caráter português, ligado às aventuras marítimas e aos empreendimentos em que se exigia mais uma propensão a arriscar-se do que o trabalho monótono, típico da indústria. Desse ponto de vista, a escolha de Simonsen em usar a moldura analítica de Lúcio Azevedo fazia sentido: trata-se de um historiador português que buscava razões para o atraso econômico de seu país - preocupava-o o problema da industrialização atrasada ou quase inexistente.

As diferenças existem: Lúcio de Azevedo estava estudando um Portugal em cuja memória nacional estavam as glórias passadas do império colonial desfalcado mas ainda existente nas colônias africanas - o país não acompanhara, todavia, as grandes potências europeias em sua marcha rumo à industrialização. Ademais, o contexto político era de instabilidade: vale lembrar que o movimento que levaria ao Estado Novo em Portugal tivera início em 1926 e o livro de Azevedo é de 1928. O Brasil, por sua vez, deveria, na ótica de Simonsen, superar o passado colonial, a situação de atraso e o papel de fornecedor de gêneros primários ou coloniais, por meio da industrialização, que ainda estaria por vir, como

\footnotetext{
${ }^{232}$ AZEVEDO, [1928] 1978, p. 354.

${ }^{233}$ AZEVEDO, [1928] 1978, p. 442.
} 
necessidade histórica. De toda forma, Simonsen apropriou-se de uma moldura com a qual se estudara o atraso econômico, para mostrar a instabilidade de economias baseadas na busca pela riqueza auferida do comércio de um grupo restrito de produtos - e não da manufatura ou da indústria.

Dentro dessa proposta, Simonsen introduz, no capítulo III de seu livro, ${ }^{234}$ o primeiro ciclo econômico brasileiro, o do pau-brasil, ou das madeiras tintoriais, muito usadas na Europa, antes da invenção das anilinas sintéticas, que se vulgarizaram no século XIX. Portugal, envolvido com o lucrativo escambo com o Oriente, dedicou pouca atenção à terra de Santa Cruz, arrendando terras a particulares que, praticando a atividade extrativa, remuneravam a Coroa. O caráter feitorial da atividade extrativa tornou as terras recém-descobertas atrativas para a exploração e o corso franceses. A concorrência francesa e a busca de metais preciosos motivaram o envio de Martim Afonso de Souza, visando a uma ocupação mais definitiva das novas terras. Ainda assim, os resultados da empresa extrativa foram poucos, só poderiam ser colhidos depois da "formação de um organismo social próprio, com a definitiva ocupação do solo e os benefícios da sua exploração"235. As políticas coloniais portuguesas foram responsáveis por não ter o Brasil se beneficiado da extração das madeiras, tendo em vista o atraso e o isolamento que aqui se verificavam. Simonsen tece algumas considerações sobre os padrões monetários vigorantes no Brasil colonial, destacando as dificuldades de mensurar o poder aquisitivo da moeda, em virtude do uso frequente do expediente da quebra, sempre que a Coroa necessitasse expandir os haveres monetários. Ressalta-se que, na economia do dia-adia da Colônia, não prevalecia o uso da moeda.

O capítulo IV ${ }^{236}$ é uma continuação do III, na medida em que explica a forma pela qual se deu a ocupação definitiva da terra de Santa Cruz, ainda pouco explorada, por ser menos rentável que as possessões lusas na Ásia, ligadas ao ciclo da pimenta. O estabelecimento das donatarias é visto como uma continuação da política de D. João III. Insatisfeito com os resultados da expedição de Martim Afonso de Souza, que não encontrara metais preciosos a partir do planalto de Piratininga, o rei teria resolvido promover a ocupação mais definitiva do território americano.

Simonsen posiciona-se de forma enfática ao atribuir ao regime das donatarias caráter capitalista, e não feudal. Sem recursos suficientes para custear a ocupação das novas terras, o rei teria concedido parte de seus direitos políticos aos capitães-donatários em troca dos riscos que estes correriam ao lançar-se à empresa colonizadora. O objetivo da Coroa era, contudo,

\footnotetext{
${ }^{234}$ O cap. III, “Aproveitamento econômico das terras de Santa Cruz”, refere-se à aula dada em 24 de abril de 1936. ${ }^{235}$ HEB, p. 61.

${ }^{236}$ O cap. IV, "Políticas coloniais", refere-se à aula de 8 de maio de 1936.
} 
assegurar para si os dízimos, monopólios comerciais e demais formas possíveis de auferir renda. Também para os donatários e colonos "o fito do lucro era a causa primordial da vinda para o Brasil". ${ }^{237}$ Sendo assim, não se poderia atribuir a essa economia colonial o caráter de feudal, pois, no sistema medieval, as remunerações eram pagas de acordo com a função social das classes, que são estanques, não havendo o "fito de lucro". Ademais, a conquista do Brasil, a partir de 1500, estaria inserida no contexto da expansão marítima portuguesa, cujo móvel era a busca de riquezas, num contexto já não feudal. Os autores usados para esta discussão são João Lúcio de Azevedo e Schmoller.

Com todas as dificuldades inerentes e a despeito da rentabilidade não muito elevada, o empreendimento das donatarias, aliado ao estabelecimento do Governo-geral em 1549, teve, segundo Simonsen, o mérito de fixar as bases para a ocupação definitiva do território, a qual seria efetivada pela criação da grande indústria do açúcar, "de que o Brasil se ia tornar o primeiro fornecedor do mundo, reembolsando regiamente Portugal e portugueses das despesas feitas com esses trabalhos preparatórios". ${ }^{238} \mathrm{O}$ açúcar tornou-se importante a partir da alta geral de preços produzida pela revolução comercial: já produzido nas ilhas atlânticas, o produto passou a ser cultivado no Brasil ainda na primeira metade do século XVI, como iniciativa particular, de colonos que recebiam adiantamentos dos donatários e de negociantes. Um traço importante dessa "indústria", segundo Simonsen, foi ser litorânea, devido às dificuldades de locomoção e aos riscos de ataques de silvícolas.

$\mathrm{A}$ atividade açucareira é analisada, no capítulo $\mathrm{V},{ }^{239}$ a partir de alguns documentos, publicados em finais do século XIX e primeiras décadas do século XX: a "História do Brasil", de Frei Vicente do Salvador; os "Diálogos das grandezas do Brasil”, cuja autoria não era conhecida à época, sendo atribuída por Simonsen ao interlocutor Brandônio; "Cultura e opulência do Brasil por suas drogas e minas", de João Antônio Andreoni (Antonil); "Descrezão da fazenda que o Collegio de Santo Antão tem no Brasil e seus rendimentos", do padre Estêvão Pereira, S.J.; e "História da América Portuguesa", de Rocha Pita. ${ }^{240}$ O objetivo da análise desses documentos é a descrição da atividade açucareira: fabrico do açúcar,

\footnotetext{
${ }^{237} H E B$, p. 81.

${ }^{238} H E B$, p. 92.

${ }^{239}$ O cap. V, “O ciclo do açúcar" se refere à aula de 22 de maio de 1936.

${ }^{240}$ Sobre os documentos consultados por Simonsen, relativos ao ciclo do açúcar, algumas observações são relevantes, já que Simonsen não cita a origem precisa das fontes que consultou. Pertencem à Coleção Roberto Simonsen: a História do Brasil (1500-1627), de Frei Vicente do Salvador, na edição de 1918, revista e comentada por Capistrano de Abreu; e os Diálogos das grandezas do Brasil, cuja autoria à época era disputada, na edição de 1930, com introdução do mesmo Capistrano e notas de Rodolpho Garcia. A História da América Portuguesa, de Rocha Pitta, teve duas edições na segunda metade do XIX, que poderiam ter sido consultadas por Simonsen: uma de 1878, feita em Salvador, e uma de 1880, feita por Francisco Arthur da Silva, em Lisboa. A “Descrezão da fazenda (...)” teria sido mandada imprimir, de acordo com o próprio Simonsen, no tomo IV dos Anais do Museu Paulista, por Afonso de Taunay.
} 
técnicas envolvidas, tipos de açúcar produzido. Simonsen visava também à obtenção de dados sobre a quantidade de engenhos no Brasil, informação que, a partir de estimativas médias do quantum de açúcar produzido por cada engenho e das cotações do preço do produto, permitiria dar uma ideia do valor do açúcar exportado pela América portuguesa ao longo do período colonial. Simonsen já fizera estimativas da taxa de câmbio portuguesa, o que lhe permitiu traçar um gráfico do valor da exportação de açúcar brasileiro em libras esterlinas.

Vale ressaltar o tipo de apropriação feita dos referidos documentos, em especial "Cultura e opulência do Brasil". Referindo-se ao fato de o governo português ter ordenado a apreensão do livro de Antonil, Simonsen citou, em nota de rodapé, um trecho de Calógeras que projetava, na sociedade colonial brasileira, um sentimento de nacionalismo que poderia ser insuflado a partir da leitura de um texto que narrava as potencialidades da terra.

Motivou a supressão [do livro de Antonil] o crime de dar informação por demais
exata e completa do valor da terra e das suas possibilidades (...). Mas existia outra
razão mais poderosa ainda para o auto-de-fé: o livro ensinava aos brasileiros a
grandeza e a potencialidade de sua pátria, e poderia exaltar aspirações,
principalmente após o êxito vitorioso das guerras do pau-brasil e da expulsão dos
batavos.

É anacrônico falar em sentimento de brasilidade em pleno século XVII, após as "guerras do pau-brasil" e a "expulsão dos batavos". Os habitantes da Colônia não se reconheciam, a essa altura, como brasileiros: a nação brasileira não existia, sendo difícil conceber algum patriotismo nesse contexto. Interessa aqui, porém, a forma como um fato relativo ao período colonial foi apropriado por Simonsen, em 1936, em benefício de uma interpretação que via nas políticas coloniais um meio de se fazer com que a nova nação que se constituía na América não fosse privada daquilo que sua terra lhe podia proporcionar. Essa apropriação é um indício da intenção de dar à história uma interpretação nacionalista, nos termos referidos acima: forjar uma consciência nacional que permitisse superar o atraso e a desorganização, de forma a permitir o desenvolvimento, o progresso do país, associado por Simonsen à industrialização.

Tema do capítulo $\mathrm{V}^{242}$, a escravidão brasileira é, para Simonsen, resultante da mentalidade da época moderna - havia escravos no Portugal da época e nas possessões atlânticas - e do primitivismo do ameríndio, inepto ao trabalho sedentário. O uso do trabalho

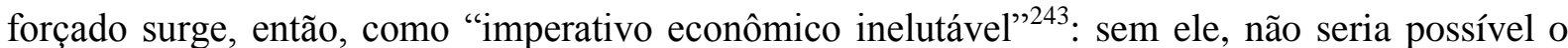
empreendimento colonial. A escravidão negra - e não "vermelha" - também é tomada como

\footnotetext{
${ }^{241} H E B$, p. 104. O trecho, segundo Simonsen, é retirado de Formação Histórica do Brasil, de Calógeras, livro que se encontra na CRB.

${ }^{242}$ O capítulo V, "Mão-de-obra servil no período colonial”, é o resultado da aula de 5 de junho de 1936.

${ }^{243}$ HEB, p. 126.
} 
necessária, seria uma mão-de-obra para resistir "onde o íncola assim fracassava". ${ }^{244}$ Como fez com a maioria dos assuntos abordados, Simonsen procurava quantificar: o número de escravos importados é estimado por meio do cotejo de estimativas de autores como Varnhagen e o padre Vieira e de cronistas, como Saint-Hilaire e Humboldt. ${ }^{245}$ Divide a demanda por cativos, até a extinção do tráfico em 1850, entre as rubricas: açúcar, café, mineração e "outros misteres", chegando a um total de 3.300.000 escravos importados. Por meio dos trabalhos de Scelle, Calógeras e Taunay ${ }^{246}$, explicou o conceito de "peça da Índia": um escravo ou conjunto de escravos considerados aptos a fornecer uma dada quantidade de trabalho. A partir daí, analisou os direitos cobrados pelos governos, para se ter uma ideia do valor dos escravos transacionados no período colonial.

Sem entrar no mérito das estimações calculadas, convém apresentar alguns aspectos relevantes da interpretação da escravidão apresentada por Simonsen. Era uma visão, em certa medida, associada à inferioridade do negro e à corrente de pensamento ligada às teses do embranquecimento da população, presentes em Sílvio Romero e Oliveira Viana, como fica claro no trecho "a parte mais penosa do trabalho foi transferida para aqueles que a natureza ou a organização social colocou em estado de inferioridade". ${ }^{247}$ Porém, duas citações à obra de Gilberto Freyre, quase contemporânea ao curso dado por Simonsen na ELSP, apontam no sentido contrário: Simonsen se aproximava das teses da democracia racial.

Aliás fomos dos mais brandos em sua utilização [da escravidão]; e o entrelaçamento
de classes que entre nós se verifica comprova esse fato, pois tal não seria possível,
se o ódio de raças se tivesse aqui arraigado, como resíduo e como reação contra
iníquos tratamentos do passado.

A questão racial não é central ao pensamento de Simonsen, mas vale mencionar que sua apropriação de Freyre, para elogiar a criatividade do português nos trópicos e enfatizar o fato de que o negro prevaleceu sobre o indígena por estar num estágio cultural - e não racial mais avançado, mostra que nosso autor não estava alheio às mudanças ocorridas no pensamento antropológico europeu e americano, refletidas no Brasil por Capistrano de Abreu, Manoel Bonfim e pelo próprio Freyre, que passava a adotar o conceito de cultura em detrimento do de raça. ${ }^{249}$ Ademais, o reconhecimento do entrelaçamento racial como fator positivo aponta para um nacionalismo que não atribui às questões étnicas os entraves à "evolução progressista": o Brasil não era pobre por que em suas terras vivia uma "raça

\footnotetext{
${ }^{244}$ HEB, p. 129.

${ }^{245}$ Desses autores, cujas obras Simonsen não cita, foi possível identificar que Varnhagen frequentou a biblioteca de Simonsen: pertence à CRS a sua História Geral do Brasil, editada em São Paulo pela Melhoramentos.

${ }^{246}$ Pertenceram à biblioteca de Simonsen os trabalhos de Scelle (La traite negrière. Paris: L. Larose \& L. Tenin, 1906) e

Calógeras (Política exterior do império. São Paulo, SP: Companhia Editora Nacional, 1927-1933).

${ }^{247} H E B$, p. 140.

${ }^{248} H E B$, p. 143.

${ }^{249}$ Sobre Simonsen e o pensamento racial brasileiro ver MAZA, 2004, pp. 116-122.
} 
degenerada", as causas dessa pobreza estavam nas políticas coloniais, que visavam à captura das riquezas da terra, e acabaram por gerar uma nação imperfeita, desorganizada.

\section{Parte 2: Assegurando a unidade nacional: interiorização (capítulos VII-XII)}

Sendo o açúcar, produzido próximo aos portos de escoamento, a principal atividade exportadora da Colônia - o gráfico feito por Simonsen atesta que a exportação aurífera, mesmo em seu apogeu, nunca superou a açucareira -, cumpria explicar o fato de o Brasil ser um país continental, cuja grande área teria sido assegurada por uma "trama social" que o manteve unitário. Os fundamentos econômicos da conquista do sertão, que permitiram fosse urdida essa trama seriam, para Simonsen, quatro, a saber: a criação de gado, a caça ao gentio pelos paulistas, a mineração e, no Vale do Amazonas, a extração de produtos silvestres, aliada ao cultivo do fumo e do algodão. Os capítulos VII-XII tratam dessas atividades: dois capítulos sobre a pecuária, um sobre o expansionismo paulista, dois sobre a mineração e um sobre a ocupação da Amazônia. ${ }^{250}$ As fontes usadas para o texto sobre a pecuária são os documentos publicados já referidos, como os Diálogos das grandezas do Brasil e a obra de Antonil, além de um grupo de documentos de final do século XVIII, impressos em São Paulo, sob o nome de "Documentos interessantes do Archivo do Estado de São Paulo". A bibliografia é composta por obras de Capistrano, Varnhagen, Southey e Oliveira Viana, dentre outros.

A criação de gado era vista como atividade que, de início, deu retaguarda à produção açucareira, proporcionando motor para os trapiches e engenhos, transporte para itens como lenha e o próprio açúcar, além de fazer parte da alimentação básica dos trabalhadores. O transporte, no interior da Colônia, era feito, em grande medida, pelas tropas, sobretudo de muares: surgia "a figura estóica do tropeiro, o grande assegurador dos meios de comunicação e transporte, nos séculos XVIII e XIX"251.

A mineração, criadora de uma demanda sem precedentes pelo gado, foi o segundo fator importante para o desenvolvimento da pecuária. Os altos preços pagos por animais nas concentrações urbanas de mineiros provocou elevação geral no preço do gado, drenando as cabeças das áreas de engenhos de açúcar. A pecuária, conforme Simonsen, também teve a função de promover a ocupação e integração econômica das regiões meridionais da Colônia, por meio do comércio de couros e, acima de tudo, pela formação da "indústria do charque".

A atividade criatória tem importância considerável no arcabouço interpretativo de Simonsen, pois era vista como um dos fundamentos econômicos da unidade nacional e talvez aquele que não

\footnotetext{
${ }^{250}$ As anotações de aula de Simonsen dão a entender que os capítulos VII e VIII foram um desmembramento da $7^{\mathrm{a}}$ aula, intitulada "Revolução Comercial - Trabalho Livre - Costa e Sertão - Criação de gado". Na anotação, não consta data. No livro, a indicação é de que a aula teria sido ministrada em 4 de setembro de 1936. Ver Anotações de aula. Dossiê Roberto Simonsen. Arquivo do CEDOC/ELSP.

${ }^{251} H E B$, p. 186.
} 
apenas interiorizou a ocupação do território, como a mineração e a busca de drogas do sertão, mas articulou esse todo pouco coerente que era o Brasil-Colônia. Roberto Simonsen percebia a articulação das economias regionais brasileiras, por meio da pecuária, a partir da economia mineradora. "Estabeleciam-se, assim, as correntes comerciais de gado pelo interior do Brasil, funcionando a zona de mineração como um providencial elo de interesses econômicos, unindo, pelo sertão, os homens do Norte, do Centro e do Sul." ${ }^{252}$ As tropas, segundo Simonsen, partiam dos campos do Sul, que se estendiam até a Colônia do Sacramento, invernando nas cercanias de Pelotas e Rio Grande, e seguiam para Laguna, onde embarcavam rumo aos campos do Paraná, para chegar a Sorocaba, a principal feira de distribuição do gado meridional. Para Simonsen, a atividade mineradora possuía

\begin{abstract}
feição caracteristicamente local, formadora de gente livre e com capitais próprios. A indústria açucareira com outra organização social funcionava, em grande parte, com capitais da metrópole, aos quais eram atribuídos os seus maiores proventos. A produção da pecuária e o seu rendimento ficavam incorporados ao país. ${ }^{253}$
\end{abstract}

Na mesma linha de Simonsen, Celso Furtado enfatizará a importância do comércio de muares como fator integrador da economia rio-grandense aos mercados coloniais, por meio da articulação com a economia mineira. Seu argumento é que a economia mineradora teria contribuído muito mais para a integração das regiões meridionais da Colônia do que a economia açucareira. A economia que se forma nas Minas tinha um coeficiente de importações muito mais elevado e renda bem menos concentrada do que a economia do açúcar. Além disso, sua localização, distante dos portos, elevava os custos do produto importado, tornando o mercado mineiro mais propício a integrar atividades de mercado interno. $^{254}$

A ideia de que Simonsen enfatiza os ciclos da economia colonial, que produzem uma riqueza que não fica na Colônia e que é dilapidada rapidamente a partir do momento que o produto-rei não encontra boa colocação no mercado externo, não deve obliterar a sua preocupação em mostrar os fundamentos econômicos da formação de um mercado interno e de uma unidade nacional duradoura, relacionados à pecuária e aos outros fatores que serão abordados em seguida: o expansionismo paulista e a atividade mineradora.

As incursões paulistas pelos sertões, tema do capítulo IX, ${ }^{255}$ eram vistas como motivadas pela situação pobre da região piratiningana, comparada ao núcleo colonial nordestino. Baseado em estudos de João Batista Aguirre, Alfredo Ellis Júnior e Afonso Taunay, Simonsen avaliou a riqueza de fazendeiros paulistas, para chegar à seguinte conclusão "Não

\footnotetext{
${ }^{252} H E B$, p. 162.

${ }^{253}$ HEB, p. 186.

${ }^{254}$ FURTADO, [1959] 2007, pp. 125-126.

${ }^{255}$ O capítulo IX, "Os fundamentos econômicos da expansão paulista", resultou da aula de 25 de setembro de 1936.
} 
há, portanto, confronto possível entre a pobreza paulista e a fartura usufruída no Brasil açucareiro". O estudo de Alfredo Ellis, pertencente à CRS, é uma pesquisa baseada nos documentos seiscentistas publicados pelos governos estadual e municipal de São Paulo.

Devido à pobreza do planalto de Piratininga, onde não avultavam produtos tropicais que interessassem ao comércio Colônia-Metrópole, a mão-de-obra teve de ser recrutada entre os indígenas, e a preação dos mesmos tornou-se a razão primeira da existência das bandeiras, de acordo com Simonsen. A outra causa principal do expansionismo seria a busca de riquezas, nomeadamente metais preciosos, com vistas a superar a situação de carestia da região. Simonsen reconhecia dois movimentos sertanistas, relacionados a cada uma dessas causas: o primeiro seria o ciclo despovoador dos sertões, que despovoava pela matança dos índios e pelas guerras aos jesuítas; o segundo movimento foi o repovoador, que promovera a ocupação do território pela pecuária e, em fins do século XVII, pela descoberta de metais preciosos.

\begin{abstract}
Além dessas expedições destruidoras, já irradiavam os paulistas em bandeiras colonizadoras, ocupando o vale do Paraíba, galgando a Mantiqueira e penetrando, com os currais, no vale do São Francisco e nos sertões nordestinos. Era a emigração em busca de meios mais fartos de subsistência do que os proporcionados pelos planaltos pobres de Piratininga. Na última década do século, graças ao aparecimento das ricas jazidas dos Cataguazes, muda por completo o caráter dessas bandeiras paulistas. ${ }^{256}$
\end{abstract}

Para além dos documentos publicados mencionados acima, a principal referência para tratar do expansionismo paulista era Afonso de Taunay. Simonsen referiu dois estudos de Taunay sobre São Paulo no século XVII, além da História geral das bandeiras paulistas, de 1924, a qual possuía em sua biblioteca. O capítulo IX de $H E B$ é dedicado a Taunay e, nos anexos, publica-se uma carta de sua autoria ${ }^{257}$, elogiando o livro de Simonsen que, naquela altura, só tivera um tomo publicado.

Simonsen oscilava, em $H E B$, entre uma interpretação mais abrangente e crítica do sertanismo paulista e a reprodução de uma historiografia preocupada em exaltar os feitos da gente de São Paulo, cuja principal contribuição ao Brasil, no período colonial, teria sido a interiorização do território, por meio dos bandeirantes. O trecho citado acima contrasta com este:

O amortecimento econômico de vastas regiões do sertão brasileiro faz esquecer que, há dois séculos atrás, por ali já passara uma fronteira econômica flutuante, carregada pelos "potentados" paulistas, que nos asseguraram a posse do que hoje é nosso. ${ }^{258}$

Embora fosse a referência mais importante, Afonso de Taunay não era a única. Simonsen recorreu a Oliveira Viana para destacar a centralidade da figura do senhor-de-engenho, ou do

\footnotetext{
${ }^{256}$ HEB, p. 214.

${ }^{257}$ A carta é datada de 17 de setembro de 1937. Vale lembrar que a primeira edição de $H E B$ saiu em dois tomos, sendo que o primeiro incluía o capítulo sobre o expansionismo paulista.

${ }^{258} H E B$, p. 240.
} 
fazendeiro, na organização social, mesmo em São Paulo, onde os inventários mostravam que a terra pouco valia. As citações a Oliveira Viana podem ser um indício da proximidade de Simonsen com ideias advindas do pensamento nacionalista autoritário. A expressão, já referida acima, designa uma corrente intelectual, importante na Primeira República e com ecos ao longo dos anos 1930 e 1940, que questionava o caráter oligárquico do regime republicano implantado no Brasil e procurou formular interpretações do passado colonial brasileiro, buscando nele as origens não só da identidade brasileira, mas, também, dos entraves ao progresso nacional. ${ }^{259}$

$\mathrm{O}$ estudo do outro fator de interiorização do Brasil, tema dos capítulos X e XI, ${ }^{260}$ inicia-se com uma exposição sobre a importância histórica dos metais preciosos, no contexto pósfeudalismo: com o aumento das correntes comerciais entre Ocidente e Oriente, não produzindo a Europa artigos de valor para permuta com os gêneros asiáticos, era com ouro e prata que se saldavam os débitos comerciais. Para além da intensificação comercial, as somas de moeda metálica teriam contribuído para que os "grandes Estados em formação" pudessem organizar seus serviços públicos, pagar seus exércitos e garantir a segurança de suas condições defensivas. "A abundância de metais preciosos nos primeiros séculos dos tempos modernos exerceu decisiva influência na elaboração da economia capitalista". 261

Com os descobertos espanhóis no México e, sobretudo, na região do Peru, a prata foi a moeda internacional durante a quase totalidade dos séculos XVI e XVII. É no século XVIII que começa a formação dos grandes estoques de ouro nos tempos modernos, devido ao impulso do ouro brasileiro e a outras contribuições, que foram abalando o império da prata até que, a partir de 1870, sob a chancela do Império Britânico, adotou-se internacionalmente o padrão-ouro. Simonsen manifestava "desconfiança quanto à estabilidade dos sistemas monetários em base metálica”262 - vale lembrar que o período dos anos 1930 é marcado pelas desvalorizações competitivas, que marcaram a ruptura final do padrão-ouro internacional: “(...) agora todos os grandes países acabam de enfraquecer voluntariamente o conteúdo em ouro de suas moedas basilares". 263

Simonsen descreveu os processos de obtenção do ouro e a legislação concernente à exploração e tributação do metal, baseado no Pluto brasiliensis, de Eschwege, e em outros cronistas estrangeiros como Humboldt e Gorceix; utilizou-se, também, de figuras de Rugendas para ilustrar alguns processos. Referiu a existência, na Biblioteca Félix Pacheco,

\footnotetext{
${ }^{259}$ Ver FAUSTO, Boris. O pensamento nacionalista autoritário. Rio de Janeiro: Jorge Zahar, 2001.

${ }^{260} \mathrm{O}$ capítulo X, intitulado "Ciclo da mineração, $1^{\mathrm{a}}$ parte" e o capítulo XI, "Ciclo da mineração, $2^{\mathrm{a}}$ parte", corresponderam, respectivamente, às aulas de 30 de outubro de 1936 e 13 de novembro de 1936.

${ }^{261} H E B$, p. 257.

${ }^{262} H E B$, p. 259.

${ }^{263}$ HEB, p. 259. Ver, sobre este período da história monetária mundial, EICHENGREEN, Barry. A globalização do capital. São Paulo: ed. 34, 2000.
} 
adquirida pela Municipalidade de São Paulo, do "precioso códice de Caetano da Costa Mattoso",264, a partir do qual Simonsen reproduziu tabelas relativas ao imposto de capitação, que permitem dar uma ideia da população escrava da região mineira no século XVIII. Estão presentes, no capítulo sobre a mineração, referências frequentes ao longo do livro, como Calógeras e o próprio Taunay, cujas observações sobre o assunto são publicadas em anexo. Para além de fazer essas descrições, Simonsen percebia a importância do "ciclo minerador" brasileiro para a metrópole portuguesa em crise e, sobretudo, para que a Grã-Bretanha se estruturasse como a principal potência econômica mundial e, concomitantemente, organizasse um sistema monetário baseado no ouro. Para isso, tivera importância o Tratado de Methuen e outros, firmados anteriormente, resultantes da aproximação portuguesa com a Inglaterra, após a separação em relação à Coroa espanhola.

Ora, o ouro do Brasil não ficaria em Portugal em pagamento de seus vinhos, nem
nas reservas do erário real que, sem saldos efetivos, não poderia retê-lo; atravessava
o país em demanda da Inglaterra, em pagamento da balança de comércio,
inteiramente favorável a esta nação. Estimulando o trabalho inglês, remunerando
melhor as suas mercadorias, concorreu para o progresso efetivo daquele povo, muito
mais do que para o enriquecimento de Portugal. 265

Talvez seja a empresa mineradora a atividade econômica que mais apresenta caráter de "ciclo" na obra de Simonsen: o açúcar, apesar do declínio em seu preço, mantém-se em produção e continua a caracterizar a parte Norte da Colônia. O destaque dado à decadência da mineração é bem maior: "cessada a mineração, mergulhou o Centro-sul na sua primeira grande crise por falta de uma produção rica e exportável". ${ }^{266}$ A crise só teria solução, para Simonsen, com a cafeicultura: o "deslocamento", no Centro-sul, da mineração para a produção agrícola teria durado cerca de 50 anos, que compreendem o período em que o Brasil se tornou independente. Essa visão, marcada pela ideia dos ciclos exportadores como mola mestra da economia, convivia com o reconhecimento da mineração como atividade importante para a constituição da "trama" unificadora do Brasil, nos termos colocados acima. Se foi efêmera como atividade de exportação, contribuiu para a integração da Colônia, para sua ocupação por novas correntes populacionais e até para reativar certas regiões, por meio da alta de preços promovida.

Para a colônia [o ouro] ficou representado no custeio das correntes imigratórias, que ocuparam os sertões brasileiros, na importação de mais algumas centenas de milhares de escravos, na construção das primeiras cidades e estradas dos nossos sertões, no desenvolvimento do Rio de Janeiro, na formação das correntes comerciais no interior do país, promovidas e mantidas principalmente pelos paulistas. Na colonização do Sul, na valorização do seu gado e num renascimento

\footnotetext{
${ }^{264}$ HEB, p. 296, Anexo I.

${ }^{265} H E B$, p. 267.

${ }^{266}$ HEB, p. 294.
} 
reflexo das zonas do Norte pelo alteamento dos preços de seus produtos nos mercados internacionais. ${ }^{267}$

A ocupação da região amazônica, destacada no capítulo $\mathrm{XII}^{268}$ como um dos grandes feitos da colonização portuguesa na América meridional, fecha os capítulos em que Simonsen tratou dos fatores asseguradores da unidade nacional brasileira. A principal referência é João Lúcio de Azevedo, cujo livro Os Jesuítas no Grão-Pará foi usado para se discutir o principal tema do capítulo, que é o conflito entre jesuítas e colonos, em disputa pelo poder sobre o indígena, utilizado como mão-de-obra na Amazônia. Simonsen reconhecia a importância dos jesuítas e afirmava que, após a sua expulsão, por ordens do Marquês de Pombal, teria decrescido a produção artesanal e extrativa das aldeias do vale amazônico. De forma geral, a política pombalina é vista como positiva e capaz de trazer algum desenvolvimento tanto ao Maranhão, quanto ao Pará, que eram os dois polos econômicos a se alternarem, na parte setentrional da Colônia.

No final do século [XVII], acentua-se o comércio das drogas do sertão, que ia se constituir a riqueza das missões religiosas na primeira parte do século seguinte. Neste último período, o valor econômico do vale amazônico sobrepujou o resto do Estado do Maranhão. Pará, produtor de cacau, entreposto de sua exportação, cravo e drogas do sertão, torna-se mais importante que a Capitania do Maranhão. No final do século XVIII, decai o comércio amazônico e surge a grande exportação de algodão e arroz da região litorânea, registrando o período áureo da Capitania do Maranhão. ${ }^{269}$

Como fizera em outros momentos do livro, Simonsen buscava apresentar dados quantitativos: sobre a Amazônia, os números são referentes às exportações de São Luís do Maranhão, entre 1812 e 1821, e do Pará, entre 1780 e 1818. Para o Maranhão, a fonte é o relato de Maria Graham e, para o Pará, o livro de Manuel Barata. No Maranhão, cuja produção no geral é maior em valor exportado, destacavam-se o algodão e o arroz, ao passo que no Pará tinha força o arroz e o cacau. Simonsen fez curta menção ao auge e declínio da produção da borracha, observando que esta foi uma atividade já de finais do século XIX e início do século XX. A conclusão do capítulo referente ao vale amazônico remete ao projeto colocado nos capítulos sobre a pecuária, de abordar os fatores que, a despeito da condição colonial, asseguraram unidade brasileira: "Com a incorporação do Amazonas e suas ligações com o planalto central, fica concluída e explicada a trama social e a infraestrutura econômica, que se formou no Brasil no período colonial e a que nos referimos no capítulo VIII.",270

\footnotetext{
${ }^{267} H E B$, p. 294.

${ }^{268}$ O capítulo XII, "Os fundamentos econômicos da ocupação do Amazonas”, não traz a data da aula correspondente. Há uma lacuna nas notas de aula de Simonsen, presentes no acervo do CEDOC/ELSP, não sendo possível determinar as datas das aulas correspondentes aos últimos capítulos do livro.

${ }^{269}$ HEB, p. 312 .

${ }^{270}$ HEB, p. 349.
} 
Parte 3: Período joanino e balanço final (capítulos XIII-XV)

Simonsen procurou fazer, no capítulo XIII, ${ }^{271}$ um sumário do comércio colonial do Brasil, em especial no período final da Colônia. Destacavam-se as Companhias de Comércio do Grão-Pará e Maranhão e de Pernambuco e Paraíba, como iniciativas positivas, que, em tempos em que prevaleciam a insegurança nos mares, a insuficiência de capitais e a falta de recursos dos Estados, "proporcionavam os elementos necessários à garantia do comércio e da ocupação de regiões longínquas"272. O trabalho estatístico de Adrien Balbi e fontes secundárias como Taunay, Calógeras e Varnhagen serviram de base para que Simonsen tratasse da produção e comércio de alguns produtos, que não haviam ocupado lugar de destaque em capítulos anteriores, a saber: o algodão, a mandioca, o cacau, a baunilha, o cravo e outras especiarias, a pesca da baleia, o anil e o café.

Mais do que os dados relativos a esses gêneros no período colonial, convém reter, desta parte da obra, o motivo da avaliação positiva, por parte de Simonsen, da política pombalina, por mais que essa atuasse no sentido de reforçar os liames metrópole-colônia. "Pombal resolveu atuar energicamente na economia portuguesa, procurando libertá-la do jugo inglês e criando para Portugal fontes estáveis de enriquecimento". ${ }^{273}$ Pombal promoveu o crescimento da indústria portuguesa, incentivando a produção de insumos na Colônia, que deveriam ser utilizados pelas fábricas, em atividade no reino. Simonsen projetava na figura de Pombal a questão da industrialização. Uma política fomentadora das manufaturas - ou, para usar uma expressão anacrônica, uma política de fundo industrialista -, ainda que beneficiasse a Metrópole e reforçasse a condição da Colônia de fornecedora de alguns gêneros comerciais primários, é elevada à posição de uma política positiva, capaz de assegurar um enriquecimento estável, permanente. Voltaremos a este ponto mais adiante.

Os dois capítulos finais, ${ }^{274}$ que se iniciam com uma apreciação das políticas joaninas do período 1808-1821, fazem um fechamento do período colonial, já apontando para a Independência. A principal referência utilizada é o livro de Oliveira Lima, Dom João VI no Brasil, cuja primeira edição datava de 1908. Para além desta obra, Simonsen se utilizou de transcrições dos Tratados de 1810, publicadas por Pereira Pinto sob o título de Apontamentos para o Direito Internacional. Essa obra não consta da Coleção Roberto Simonsen, mas seguramente se trata de uma compilação anotada de todos os tratados firmados pelo Brasil, publicada no Rio de Janeiro, pela Tipografia Nacional, entre 1864 e 1869. Outros autores,

\footnotetext{
${ }^{271}$ O Capítulo XIII intitula-se "O comércio do Brasil na era colonial".

${ }^{272} H E B$, p. 359.

${ }^{273}$ HEB, p. 376

${ }^{274}$ São os capítulos XIV e XV: "Dom João VI no Brasil" e "Autonomia econômica e soberania política”.
} 
como Calógeras, Varnhagen e Lemos Brito, também estão presentes nessa parte final do livro: a obra deste último, Pontos de partida para a história econômica do Brasil (1 ${ }^{\mathrm{a}}$ edição de 1923), aparece aqui pela primeira vez na obra de Simonsen.

A avaliação feita por Simonsen do período joanino era ambivalente. Considerava positivas várias medidas tomadas pela administração portuguesa no Rio de Janeiro, a saber: a fundação do primeiro Banco do Brasil, o incentivo à vinda de imigrantes suíços, as tentativas de se instalar a metalurgia do ferro no país e o incentivo à navegação de cabotagem, por meio do fomento aos estaleiros e aos estudos hidrográficos. Essas medidas, de cunho mais econômico, aliadas à instalação de uma administração governamental no Brasil, dotada de poder próprio, teriam contribuído para a superação de vários elementos coloniais da economia brasileira.

\begin{abstract}
Essa mudança [da Corte] veio suprimir, portanto, muitos dos aspectos meramente coloniais da economia brasileira. Sob o ponto de vista político e administrativo, criou mesmo no país organizações marcantes de uma monarquia absoluta, necessárias ao funcionamento de nação política e administrativamente independente. $^{275}$
\end{abstract}

O alvo da crítica de Simonsen era a política comercial de D. João VI, consubstanciada nos Tratados de 1810. Simonsen utilizou a obra de Vítor Viana para atribuir à geração intelectual que fez a Independência uma filiação às ideias de Adam Smith. Autores como José da Silva Lisboa (o Visconde de Cairu), João Rodrigues de Brito, Januário da Cunha Barbosa e Gonçalves Ledo são vistos como "cheios" de Gournay, Adam Smith e Say. ${ }^{276}$ Embora reconhecesse alguns efeitos benéficos no curto prazo das políticas de abertura comercial, Simonsen via tais medidas como lesivas ao desenvolvimento brasileiro.

O manifesto com que D. João VI procurou justificar aos seus vassalos de Portugal e do Brasil os tratados que acabara de assinar demonstra a intervenção que sobre esse e outros atos de governo tiveram na época os economistas da Escola Liberal. (...). Não era essa, infelizmente, a política comercial que conviria a um país como o nosso, que apenas iniciava a sua economia independente. ${ }^{277}$

Aproveitando as observações sobre a política comercial adotada por D. João VI, pode-se esboçar alguns elementos explicativos que podem ajudar a compreender o tipo de interpretação presente em História econômica do Brasil. Como vimos, HEB é o resultado do curso ministrado por Simonsen em 1936. No ano imediatamente anterior, o Brasil firmara o Tratado Comercial Brasil-Estados Unidos, que concedia a este país cláusula de nação favorecida no mercado brasileiro. Sem entrar em considerações mais detidas sobre o Tratado de 1935, vale frisar que no ano em que ministrou o curso pela primeira vez, 1936, Simonsen

\footnotetext{
${ }^{275} H E B$, p. 391.

${ }^{276} H E B$, p. 435 , nota 9.

${ }^{277} H E B$, p. 405.
} 
era diretor da FIESP e deputado classista, representante dos industriais paulistas, na Câmara dos Deputados, onde se deu o debate em torno da ratificação do referido acordo. Sua participação foi das mais ativas - e enfaticamente contrárias ao Tratado - como será discutido mais adiante. Para defender sua posição contrária ao acordo, que de fato permitia a entrada no Brasil, de produtos que já possuíam similar nacional, especialmente têxteis, Simonsen mobilizou argumentos históricos para dizer que políticas liberais acabaram por sujeitar o Brasil aos interesses de outros povos. Abaixo, um trecho do discurso de Simonsen, em 1935:

\begin{abstract}
Denunciados os primeiros tratados de commercio, não soubemos manter uma orientação continua e conveniente em politica aduaneira. Nas agitações politicas em que vivíamos sujeitos ás influencias de grandes interesses num meio ainda não bem chrystallizado, as reformas das tarifas aduaneiras succederam-se umas sobre as outras, em medidas precipitadas ou em contra-marchas desastrosas. Emquanto os Estados Unidos tinham o animo bastante forte para resistir a taes investidas nós não comprehendemos o problema economico brasileiro, e seguimos a nossa evolução, obedecendo aos determinismos economicos do meio, ou ás directrizes que nos eram impostas pelas politicas commerciaes das economias de outros povos. ${ }^{278}$
\end{abstract}

\title{
2.2.2. A História econômica do Brasil e o projeto industrialista de Simonsen
}

A interpretação dos tratados do período joanino parece muito influenciada pelas questões da atualidade de Simonsen: era necessário evitar que um tratado comercial lesasse os interesses da classe dos industriais. Embora publicado em 1937, o curso de história econômica foi ministrado por Simonsen em 1936 e suas pesquisas e leituras certamente se realizaram simultaneamente à preparação dos argumentos para o ataque ao Tratado de 1935 . Isso ajuda a perceber que a interpretação dada por Simonsen à história econômica do Brasil está diretamente associada com seu projeto de classe e com as questões políticas prementes em seu tempo.

Elogiava-se Dom João VI por suas medidas que se revelaram fomentadoras da autonomia política do Brasil, como a instalação de uma estrutura governativa no Rio de Janeiro e as tentativas de diversificação produtiva. Os Tratados de 1810, entretanto, foram encarados isoladamente - e severamente criticados, como produtos da "Escola Liberal", inadequados ao Brasil. Simonsen não deixava de reconhecer as dificuldades de Portugal, entre a Inglaterra e a França, que forçaram a abertura dos portos, mas ressaltava a inconveniência do liberalismo comercial, seu caráter antagônico aos "interesses nacionais". Ora, quais seriam esses interesses "nacionais" em 1808-1810? Da mesma forma como fizera no caso da censura ao livro Diálogos das grandezas do Brasil, Simonsen projetou nesse episódio dos Tratados de 1810 o nacionalismo que professava: certamente não havia uma elite nacional brasileira cujos interesses fossem opostos aos da liberalização comercial - a nação ainda não se havia

\footnotetext{
${ }^{278}$ Anais da Câmara dos Deputados, v. XVI(11/09/1935). p. 303.
} 
constituído como tal. ${ }^{279}$ Os referidos interesses nacionais do início do século XIX eram, na interpretação de Simonsen, interesses semelhantes àqueles que defendia na Câmara dos Deputados, isto é, a posição contrária à abertura comercial.

Passando de uma questão particular - os tratados do período joanino - para o caráter mais geral da obra, convém relembrar que o projeto que permeia toda a construção de Simonsen é nacionalista, no sentido específico que associa progresso nacional e industrialização. A leitura proposta aqui, que divide o livro em partes, ajuda a compreender melhor essa questão. $\mathrm{Na}$ primeira parte, Simonsen mostrou uma Colônia integralmente voltada para fora: são os ciclos do pau-brasil e do açúcar, esta última economia sendo a mais importante de todo o período colonial. No segundo momento, destacam-se a mineração, a pecuária, o expansionismo paulista e a ocupação amazônica, como atividades que, para além de estarem articuladas ao sistema metrópole-colônia, contribuíam para assegurar a "trama social" que une o Brasil. A mineração é claramente uma atividade colonial, atuando inclusive como fonte de acumulação para a Revolução Industrial britânica, por meio da balança comercial portuguesa, mas suas virtudes voltadas para o "mercado interno" eram ressaltadas.

Nesse sentido, os elementos asseguradores da unidade nacional são aqueles que não se dilapidam quando um determinado produto perde a sua colocação no mercado internacional. O açúcar, para além de ser um produto de exportação, proporcionou a fixação definitiva do português no Brasil. O sertanismo paulista teve importância por interiorizar o território por meio, por exemplo, dos descobertos minerais - e isso não se desarticulou ao término do ciclo da mineração, por exemplo, embora tenha perdido força. A mineração articulou as regiões da Colônia, o que permaneceu, mesmo após a o declínio da produção aurífera. A pecuária foi o veículo dessa articulação, proporcionando transporte e alimento para várias regiões, num processo duradouro de ocupação territorial e integração econômica.

Ora, os chamados "ciclos" são "ciclos" porque aquilo que legam ao país não é permanente: a riqueza produzida não fica na terra, é apenas uma ilusão de riqueza. Não se volta exatamente ao ponto de partida, é certo, mas o grosso da riqueza produzida nos ciclos da economia colonial é enviado para fora. Quanto menos voltada para fora, menos sujeita aos sabores do mercado internacional é a atividade, menos cíclica ela é: Simonsen não falava em ciclo da pecuária, nem ciclo do expansionismo paulista. As economias cíclicas são incapazes de promover o progresso nacional, pois a riqueza que produzem é efêmera. Aqui vale retomar e elogio ao Marquês de

\footnotetext{
${ }^{279}$ A ideia de nação brasileira, associada a uma entidade estatal asseguradora da unidade territorial, deve ser entendida em sentido histórico: a partir da constituição do Estado imperial e, sobretudo, no Segundo Reinado, há um movimento importante de construção da identidade nacional associada ao Estado brasileiro. Nesse sentido, falar em nacionalidade brasileira contrária aos tratados de abertura comercial dos tratados de abertura anteriores à Independência e a esse processo de construção da identidade nacional é um anacronismo. Trata-se, todavia, de um anacronismo explicável a partir da perspectiva nacionalistaindustrialista adotada por Simonsen.
} 
Pombal: seu mérito, conforme Simonsen, foi tentar dotar Portugal de fontes estáveis de riqueza. Fontes estáveis de riqueza eram, basicamente, atividades manufatureiras e industriais, voltadas para o mercado interno. Quando descreveu as economias coloniais como ciclos, Simonsen lhes conferiu caráter instável, diferente do caráter da atividade industrial: esta, sim, estável por estar voltada para o mercado interno - e não dependente das incertezas do mercado internacional seria capaz de articular o país em torno do progresso nacional.

Como já foi mencionado, a abordagem presente em $H E B$ era coerente com o projeto nacionalista-industralista de Simonsen: o fato de que a economia colonial era cíclica, ou dominada por processos de produção e dilapidação rápida da riqueza, implicava que a mesma não deixava um legado permanente à nação. Os fatores asseguradores da unidade nacional são aqueles que produzem efeitos duradouros, daí a valorização da pecuária, da mineração e do expansionismo paulista. A construção da nação é vista como obra inconclusa: ainda que tenham assegurado a unidade nacional, os fatores articuladores jamais conseguiram, num contexto colonial, prevalecer sobre a dinâmica dos ciclos do pau-brasil, do açúcar e da mineração. Embora tenham deixado traços importantes, esses fatores não asseguraram a formação de uma nação moderna, livre da "desorganização" que a impedia de progredir, de se enriquecer. Prevaleceu, como é evidente, a dinâmica cíclica - sujeita às flutuações de fora - que gerou inúmeros entraves ao progresso: a superação disso passaria, não por um novo ciclo, nem pela assinatura de tratados comerciais, mas pela autonomia política, cuja construção iniciara-se com D. João VI, e econômica, que viria, para Simonsen, com a industrialização.

2.3. Outras contribuições historiográficas: Aspectos da história econômica do café (1938), Evolução industrial do Brasil (1939) e Recursos econômicos e movimentos das populações $\underline{(1940)}$

O texto "Aspectos da história econômica do café" foi redigido para o III Congresso de História Nacional, do IHGB, em 1938, tendo sido publicado na Revista do Arquivo Municipal, de São Paulo, em 1941, e republicado na coletânea de Edgard Carone (1973). A Revista do Arquivo Municipal teve sua publicação iniciada em 1934, no ambiente intelectual já aludido, em que a elite paulista procurava se organizar para atuar de forma a manter seu papel de dirigente da sociedade em São Paulo e ampliar sua influência no Brasil. Publicaram neste periódico intelectuais ligados à Escola Livre de Sociologia e Política, à Universidade de São Paulo e ao Departamento de Cultura do Município de São Paulo. Em estudo sobre o papel desta revista, no período 1934-1950, Silene Claro identifica como principais temas abordados as questões relativas ao crescimento e urbanização da cidade de São Paulo, as discussões sobre mão-de-obra, condições de trabalho e migração e, relacionados a essa problemática, os 
debates raciais. Analisando as propagandas veiculadas na Revista do Arquivo Municipal, a autora chega à conclusão que o público-alvo da revista, no período recortado, era constituído de empresários, dirigentes políticos ligados ao Executivo e intelectuais - a revista seria um veículo de diálogo entre a intelectualidade de São Paulo e do resto do Brasil e vice-versa. ${ }^{280}$

O texto de Simonsen foi baseado em bibliografia citada somente no final, sem especificação de data ou edição dos textos. Simonsen utilizou alguns documentos publicados: da Diretoria Geral de Estatística do Tesouro Nacional, da Diretoria de Terras, Colonização e Imigração do Estado de São Paulo, da Secretaria de Agricultura do Estado de Minas Gerais e da firma "Lima, Nogueira e Cia", em atividade no porto de Santos. A maioria das referências, contudo, compunha-se de monografias sobre o café, de autores como Afonso de Taunay, Oliveira Viana, Pandiá Calógeras, Sérgio Milliet, dentre outros.

O ambiente intelectual de escrita e publicação deste texto sobre o café era bem semelhante ao da elaboração de HEB. Nesse sentido, pode-se dizer que Aspectos da história econômica do café é, em alguma medida, uma continuação de História econômica do Brasil e cumpre parte do plano inicial, expresso nos programas da Escola de Sociologia e Política, de dar um curso de história econômica do Brasil que abarcasse não só o período colonial, mas também as fases posteriores. A abordagem dada por Simonsen à economia cafeeira é semelhante àquela usada para tratar dos outros produtos-reis exportados pelo Brasil. $\mathrm{O}$ texto começa por uma caracterização do café e de sua importância como produto revigorante do organismo humano: originário do Oriente Médio e levado para a Europa no século XVII, seu consumo se teria firmado na França no século XVIII. ${ }^{281}$ A planta teria sido introduzida no Brasil no final do século XVIII, quando, segundo Simonsen, ainda predominava a mineração e a atividade agrícola não se havia generalizado no interior do Centro-sul brasileiro. O Brasil assumiria a posição de líder no mercado mundial de café somente em meados do século XIX.

O capítulo introdutório dos Aspectos se fecha com um sumário da história do comércio do café, relativa ao Brasil, que é dividida em cinco fases. A primeira fase seria a da propagação do café nos principais centros culturais da Europa, praticamente sem participação brasileira no comércio; o Brasil estava, neste momento, absorvido pela mineração e suas culturas agrícolas eram principalmente o açúcar e o fumo. A segunda fase (1727-1810) corresponderia à adaptação do cafeeiro ao país. O período de 1810 a 1870 seria marcado pela afirmação do café no Brasil, que passaria a responder por mais da metade da produção mundial: esta expansão se deu, sobretudo, no Vale do Paraíba, "unindo as antigas lavouras de

\footnotetext{
${ }^{280}$ CLARO, Silene Ferreira. Revista do Arquivo Municipal de São Paulo: um espaço científico e cultural esquecido. São Paulo: FFLCH/USP, 2008. Tese de Doutorado.

${ }^{281}$ SIMONSEN, Roberto. “Aspectos da história econômica do café”. [1938] . IN: EIB, pp. 164-170.
} 
cana-de-açúcar, da costa, às velhas regiões mineradoras de além-Mantiqueira". ${ }^{282}$ A partir de 1870, teria início a quarta fase, com o crescimento da produção no planalto paulista, que começaria a predominar em 1890; em 1894, o porto de Santos ultrapassaria o do Rio na exportação de café. Por fim, o quinto período começaria em 1897, marcado pela "acelerada e desordenada expansão da cultura nas regiões paulistas". ${ }^{283}$ Esta última fase estaria presente ainda no momento da escrita do texto (1938) e, segundo Simonsen, o Brasil ainda padecia seus efeitos econômicos, sociais e políticos. Como se pode perceber, a abordagem de Simonsen para a economia cafeeira também é cíclica: o produto tem uma fase inicial, adaptase, encontra boa colocação no mercado internacional durante um tempo e depois enfrenta uma crise, que não permite que o país viva somente do seu comércio. No caso do café, a crise teria sido de superprodução. O desenvolvimento do texto a partir da definição dessas cinco fases é um aprofundamento de cada uma delas.

Sobre a fase de predomínio do Vale do Paraíba, Simonsen reafirmava que seria este o momento de afirmação definitiva do café no Brasil. A economia desse Vale do Paraíba não só fluminense, mas, extensivo, também, à Zona da Mata mineira, estivera centrada em torno da cidade do Rio de Janeiro, que era centro consumidor de gêneros agrícolas e revendedor de café. O trabalho era predominantemente escravo: a escravaria e o gado que se haviam acumulado na região Centro-sul em decorrência da mineração, que entrara em decadência, pôde ser aproveitado pela cultura do café. ${ }^{284}$ Por fím, o Vale do Paraíba fluminense vai perdendo a importância no cômputo geral da produção cafeeira brasileira: primeiro, perde a primazia para São Paulo, em 1889, cedendo o segundo lugar a Minas Gerais em 1896. ${ }^{285}$

Sobre o cultivo do café no planalto paulista, Simonsen enfatizava alguns fatores que o tornavam mais rendoso, levando-o a sobrepujar a produção do Vale do Paraíba. A produtividade era maior em São Paulo devido aos solos de terra roxa, que forneciam um café mais bem cotado no mercado internacional. As ferrovias também teriam papel importante: no Rio de Janeiro também foram introduzidas, mas posteriormente à abertura de diversas estradas de rodagem e de portos marítimos e fluviais. "Enquanto a rede ferroviária fluminense foi servir zonas já produtoras, a rede paulista, ao invés, foi como que despertá-las". ${ }^{286}$ Outro fator distintivo da economia cafeeira paulista seria a forma pela qual se deu a superação do trabalho escravo: extinto o tráfico em 1850, São Paulo teria marchado na direção da substituição da mão de obra escrava pela do imigrante europeu, inclusive por meio da

\footnotetext{
${ }^{282}$ SIMONSEN, 1938, p. 174.

${ }^{283}$ SIMONSEN, 1938, p. 175.

${ }^{284}$ SIMONSEN, 1938, p. 180.

${ }^{285}$ SIMONSEN, 1938, p. 190.

${ }^{286}$ SIMONSEN, 1938, p. 194.
} 
subvenção do próprio governo estadual à imigração. O principal atrativo para o imigrante era, conforme Simonsen, a existência do regime de colonato, que permitia aos colonos cultivarem gêneros para subsistência e venda entre as linhas do café plantado. ${ }^{287}$ Além disso, essa produção de subsistência feita pelos colonos teria a importância de, ao se cansarem os cafeeiros, evitar que uma decadência tão forte se abatesse sobre as terras, tornadas menos produtivas para o cultivo da rubiácea. ${ }^{288}$ Simonsen observava que, apesar da importância da entrada dos imigrantes para a cafeicultura e para o desenvolvimento populacional de São Paulo, foi fundamental que os fazendeiros mantivessem o "sentimento nacional" nos novos núcleos populacionais, absorvendo-os, e a seus descendentes, como brasileiros. ${ }^{289}$

A parte final do texto é dedicada à fase declinante do ciclo, isto é, a superprodução. Simonsen destacava sete fatores que teriam conduzido o café à situação de superprodução, principalmente em São Paulo, a partir de 1897. Seriam eles: condições ideais de clima e de solo para a cultura cafeeira; fluxo constante de mão de obra, proporcionado pelas condições favoráveis ao colono europeu; facilidades de crédito, sobretudo na primeira década republicana; alta nos preços-ouro do café, entre 1886 e 1896, potencializada pela baixa do mil-réis; sistemas de remuneração que permitiam aos colonos auferir proventos com seus cultivos; facilidades de transportes; lucros extraordinários, que fizeram com que a atividade agrícola concentrar-se na monocultura do café. ${ }^{290}$

Diante dessa situação, posta desde a virada do século, o governo iniciou as operações de valorização do café, com a compra de estoques para posterior liquidação. Simonsen descreveu o Convênio de Taubaté, a valorização de 1917 e a de 1922, culminando com a criação do Instituto de Café do Estado de São Paulo, em 1924, que significaria a instituição de uma política de defesa permanente do café. Ainda que reconheça o êxito das operações valorizadoras, Simonsen termina o texto em tom crítico, destacando os danos causados pela superprodução de café.

Essa providência de eliminação dos excessos, perfeitamente compreensível para um curto período, nunca deveria se ter transformado em política permanente, pois que no caso brasileiro redundou em verdadeiro atentado contra a nossa economia social. (...). A superprodução não foi ainda eliminada e tampouco atacadas de frente as suas causas profundas. ${ }^{291}$

A ideia de ascensão e queda do café fica clara a partir do exposto: o produto permitiu a rearticulação do Centro-sul do Brasil e proporcionou enriquecimento considerável, sobretudo

\footnotetext{
${ }^{287}$ SIMONSEN, 1938, p. 211.

${ }^{288}$ SIMONSEN, 1938, p. 214.

${ }^{289}$ SIMONSEN, 1938, p. 212.

${ }^{290}$ SIMONSEN, 1938, p. 217.

${ }^{291}$ SIMONSEN, 1938, p. 231.
} 
em São Paulo, mas seu plantio começara a ser disfuncional para a economia brasileira: o café não seria capaz de proporcionar ao Brasil um desenvolvimento contínuo, independente dos humores do mercado internacional. Esta ideia de insuficiência da cafeicultura para atender as necessidades do desenvolvimento do Brasil já estava presente na carta à Missão Montagu, de 1924: naquela ocasião, todavia, a preocupação era mais voltada para a questão cambial do que para a superprodução. O café não seria capaz de proporcionar, sozinho, as divisas necessárias ao pagamento dos compromissos internacionais do Brasil. ${ }^{292}$

Outra obra de Simonsen que se relaciona especificamente com a história econômica, Evolução industrial do Brasil, foi publicada em 1939, pela FIESP. O texto foi redigido por uma encomenda do Conselho Federal de Comércio Exterior a Roberto Simonsen, que, neste momento, era presidente da FIESP, além de professor da ELSP. Vale recordar que Simonsen tivera uma passagem pelo CFCE, entre 1936 e 1937, quando substituíra Euvaldo Lodi. O objetivo do texto era fornecer subsídios para a Missão Universitária Norte-Americana, da Universidade da Pensilvânia, que visitava o Brasil na ocasião. ${ }^{293}$

$\mathrm{O}$ texto apresentado à Missão se baseou em obras anteriores do próprio Simonsen - HEB e Aspectos da história econômica do café -, em alguns estudos sobre a indústria brasileira e, principalmente, em dados de órgãos oficiais e entidades ligadas à indústria. $\mathrm{O}$ censo industrial de 1907, realizado pelo Centro Industrial do Brasil e o Recenseamento da República, de 1920, são utilizados. O objetivo da monografia era duplo: historiar os principais momentos do processo de industrialização no Brasil e fornecer uma explicação para as limitações dessa industrialização, se comparada à dos países ricos, em especial os Estados Unidos.

O desenvolvimento de atividades fabris teria sido, de acordo com Simonsen, muito tímido no período colonial, devido a medidas cerceadoras da metrópole portuguesa como, por exemplo, a proibição dos ourives em 1766 e o alvará de 1785, que limitou as atividades de fiação e tecelagem na Colônia. A avaliação da atuação de D. João VI mantém-se: foram positivas as iniciativas voltadas ao desenvolvimento de atividades industriais, mas os tratados de livre-comércio teriam solapado "a evolução de qualquer actividade industrial, de que houvesse congenere na Grã Bretanha". ${ }^{294}$ Durante o Império, teria havido o desenvolvimento de algumas manufaturas, sobretudo têxteis, mas a limitação principal era o alto preço dos maquinários e utensílios de ferro, permanecendo a atividade em bases manuais/artesanais. ${ }^{295}$ Simonsen via na década de 1880 e nos primeiros anos da de 1890 o primeiro surto industrial

\footnotetext{
${ }^{292}$ SIMONSEN, 1924.

${ }^{293}$ SIMONSEN, Roberto. A evolução industrial do Brasil. São Paulo: FIESP, 1939.

${ }^{294}$ SIMONSEN, 1939, pp. 21-22.

${ }^{295}$ SIMONSEN, 1939, p. 23.
} 
brasileiro, favorecido pela prosperidade mundial, pelo afluxo de capitais, pelo crescimento do volume de exportações de café e pelo aumento dos meios de pagamento no Brasil. ${ }^{296}$ No começo do século XX, o segundo surto industrial, significativo especialmente em São Paulo, fora favorecido pela imigração, pelas grandes depressões cambiais e pela instalação de usinas hidrelétricas. A Primeira Guerra Mundial teria contribuído decisivamente para essa evolução industrial paulista.

O diagnóstico geral da hora presente era que "a producção industrial do Brasil está apenas em seu inicio e que uma política economica adequada e o estabelecimento de industrias básicas podem concorrer para um extraordinario progresso". ${ }^{297}$ Simonsen completou esse histórico da indústria brasileira com a descrição da evolução de alguns setores específicos, considerados estratégicos para o desenvolvimento industrial: eletricidade, extração de carvão mineral, siderurgia, cimento e prospecção de petróleo. Os setores têxtil e os estabelecimentos frigoríficos também receberam tratamento específico. Vale ressaltar que, ao contrário de outros setores estudados por Simonsen, os ramos da indústria, voltados para o mercado interno, não tinham caráter cíclico: em todas as atividades citadas, há uma evolução incipiente, mas promissora e independente das flutuações da economia internacional.

Para além desse histórico mais descritivo, Simonsen apresentou, neste estudo, uma interpretação da dinâmica mais geral da industrialização brasileira. A ideia era que o desenvolvimento industrial brasileiro se beneficiara pouco das políticas tarifárias levadas a efeito pelos diversos governos: tais políticas tinham propósitos fiscais, muito mais do que um objetivo claramente protecionista. O móvel principal da evolução industrial do Brasil seria a desvalorização cambial crônica.

\section{O exame dos graphicos que organisamos demonstra que muito mais do que qualquer protecção tarifaria, exercem accentuada influencia sobre o nosso crescimento industrial, a crescente desvalorisação de nossas taxas cambiais e o rapido augmento de uma população que se vae cada vez mais educando. ${ }^{298}$ (grifos do autor)}

Nesse sentido a industrialização se tornava, para Simonsen, um imperativo histórico, resultado natural de uma população que crescia e passava a demandar produtos industriais que o Brasil ainda não produzia. Simonsen entendia que vários fatores favoráveis contribuíram para que o processo de industrialização se desenrolasse no Brasil: a decretação do trabalho livre em 1888; a criação de um mercado interno de alguma importância, pela cultura cafeeira e pelo afluxo de imigrantes; os progressos da energia elétrica em São Paulo e no Distrito Federal; o barateamento das máquinas operatrizes. O móvel do processo, no entanto, é o

\footnotetext{
${ }^{296}$ SIMONSEN, 1939, p. 24-25.

297 SIMONSEN, 1939, p. 69.

298 SIMONSEN, 1939, p. 34.
} 
desajuste entre a demanda e a produção internas. A demanda é diversificada e incorpora produtos agrícolas e industriais, ao passo que a produção é centrada em gêneros primários de exportação.

\begin{abstract}
Como phenomeno economico geral, as nossas exportações de produtos agricolas deixaram de proporcionar poder acquisitivo externo sufficiente para pagar os productos industriaes reclamados pelo consumo interno. A baixa do cambio brasileiro reflecte, em grande parte, a situação de desequilibrio provocada por uma população que cresce e se civilisa continuamente, e que não dispõe de meios de pagamento no exterior para os productos de que necessita. ${ }^{299}$
\end{abstract}

Essa depressão das taxas cambiais que, segundo Simonsen, é um fenômeno que reflete o referido desajuste entre oferta e demanda seria uma emulação importante para o desenvolvimento industrial brasileiro. A ideia de que a restrição às importações, imposta pela desvalorização cambial crônica e por choques externos como guerras e depressões econômicas, atuou de forma a impulsionar a industrialização é recorrente na historiografia econômica brasileira. O exemplo paradigmático disso é a interpretação de Celso Furtado para a industrialização brasileira nos anos $1930 .^{300}$

Por fim, o texto "Recursos econômicos e movimentos das populações" consiste numa aplicação desse arcabouço interpretativo das fases ou ciclos econômicos a um problema bem específico: o da dinâmica populacional brasileira. O texto, publicado em português e em inglês, foi escrito para o Oitavo Congresso Científico Americano, realizado em Washington de 10 a 18 de maio de 1940. Simonsen participou do evento a convite da Junta Executiva Central do Conselho Nacional de Estatística, sediado no Rio de Janeiro. ${ }^{301}$

$\mathrm{O}$ argumento geral do trabalho era que as populações, em qualquer tempo, movimentamse por motivos econômicos. Seria, então, a diferente disponibilidade de recursos econômicos em regiões distintas o fator a guiar a dinâmica demográfica. Ora, como vimos, a interpretação de Simonsen para a história econômica do Brasil era de que os ciclos se sucedem, alternandose os produtos-reis que puxam a economia. Nesse sentido, o argumento do texto de 1940 é que o movimento demográfico desde a época colonial reproduzia essa dinâmica econômica. A região onde se produzia o gênero que encontrava boa colocação no mercado internacional atraía populações, esvaziando-se as demais regiões, que se encontravam em crise. O movimento populacional acompanharia o os deslocamentos do eixo econômico do Brasil, descritos logo no início do texto:

\footnotetext{
${ }^{299}$ SIMONSEN, 1939, p. 20

300 Ver FURTADO, 2007 [1959], caps. XX-XXIII, e, sobre as interpretações ligadas a essa ideia da restrição externa, SUZIGAN, 2000, cap. I.

${ }^{301}$ A primeira publicação, em português, do referido texto foi na Revista Brasileira de Estatística, n. 2., abril-junho de 1940. A versão traduzida para o inglês foi publicada nos anais do Oitavo Congresso Científico Americano, em maio de 1940. O texto foi republicado na coletânea $E S P E$, de 1943. As referências aqui são a esta última versão do texto. Ver ESPE, pp. 120-157.
} 
O eixo econômico do Brasil, primitivamente no Norte, nos séculos XVI e XVII, deslocou-se para o Centro-sul, no século XVIII, na época da mineração do ouro, para voltar, por algum tempo, para o Norte, instalando-se, afinal, definitivamente, no Sul, no século XIX, ao influxo da cultura do café. ${ }^{302}$

O primeiro grande fluxo migratório da colônia foi, para Simonsen, ocasionado pela descoberta do ouro das Minas Gerais e de Mato Grosso, que teria atraído a população ligada às atividades açucareiras no Norte e em São Vicente. "Pela fascinação do ouro e instigados ainda pela depressão econômica das zonas açucareiras, operou-se, então, um pronunciado movimento emigratório das regiões dos engenhos para as terras da mineração". 303 A cultura do café no Vale do Paraíba teria promovido o próximo movimento migratório: essa economia teria tornado possível "o aproveitamento de considerável massa de descendentes dos antigos mineradores", atraindo também correntes migratórias das regiões setentrionais, onde as culturas tropicais estavam estagnadas. ${ }^{304}$ Simonsen citou ainda o fluxo migratório do Nordeste do país para o vale amazônico, entre 1869 e 1910, em virtude da indústria da borracha. Por fim, o cultivo de café no planalto paulista, mais produtivo, teria atraído populações do Vale do Paraíba, do Norte e de Minas Gerais.

Na interpretação de Simonsen, tiveram lugar, em São Paulo, outros fenômenos, para além do café, que atraíam populações: outras culturas, como a do algodão, estavam drenando mão de obra de regiões como o sudeste da Bahia e os sertões do norte de Minas, assolados pela seca no momento em que o texto foi escrito (1938-39). ${ }^{305} \mathrm{O}$ principal processo, todavia, que permitia a fixação de contingentes populacionais em São Paulo era a industrialização em curso e as atividades voltadas para o mercado interno cujo desenvolvimento a economia paulista fomentava.

No regime de economia eclética, que hoje impera, já não se faz sentir, no Estado, tão intensamente, a crise do café, e o mercado interno está-se tornando mais interessante para a lavoura, indústria e comércio do que a própria exportação! Este novo regime proporcionará, para a população de São Paulo, condições de equilíbrio econômico muito mais estáveis. ${ }^{306}$

$\mathrm{O}$ argumento de que a economia eclética, comportando um setor industrial dinâmico e atividades agrícolas não apenas voltadas para a exportação, proporcionava mais equilíbrio e estabilidade, não é a novidade deste texto. Como vimos, a ideia já estava presente na História econômica do Brasil. O diferencial desta contribuição de 1940 é a apresentação de dados mais

\footnotetext{
302 SIMONSEN, Roberto. "Recursos econômicos e movimentos das populações". [1940]. IN: ESPE, p. 126.

${ }^{303}$ SIMONSEN, 1940, p. 129.

${ }^{304}$ SIMONSEN, 1940, p. 130.

${ }^{305}$ SIMONSEN, 1940, p. 142.

${ }^{306}$ SIMONSEN, 1940, p. 151. Sobre o Rio de Janeiro, Simonsen menciona que o crescimento da cidade se devia, sobretudo, a estarem ali sediados o Governo Federal e os departamentos da administração pública: tal crescimento estaria ocorrendo mais depressa que o incremento na produção de meios de subsistência, levando a controles de preço e aumentos abusivos nos aluguéis.
} 
precisos, que davam sustentação à argumentação. Simonsen fez estimativas dos níveis de vida e produtividade dos vários estados da Federação, com base em dados da contribuição tributária dos mesmos. Procurou mensurar, também, os diferenciais salariais por setores (indústria, comércio e agricultura) entre os estados brasileiros. Para isso, utilizou-se de dados dos Institutos de Aposentadoria e Pensões dos Industriários e dos Comerciários, além de informações compiladas pelo Serviço de Estatística do Ministério da Agricultura e pelo Inquérito de Salário Mínimo (Ministério do Trabalho). ${ }^{307}$ Tratava-se de demonstrar, por meio de dados numéricos palpáveis, que as regiões que atraíam maiores contingentes populacionais eram as mais produtivas, onde se pagavam salários mais altos. Ademais, Simonsen elaborou, a partir dessas informações mapas que ilustravam os movimentos demográficos e as diferenças regionais, no tocante aos níveis de vida. O mapa abaixo traz os níveis de vida por região e o método de cálculo utilizado para se chegar ao índice de padrão de vida.

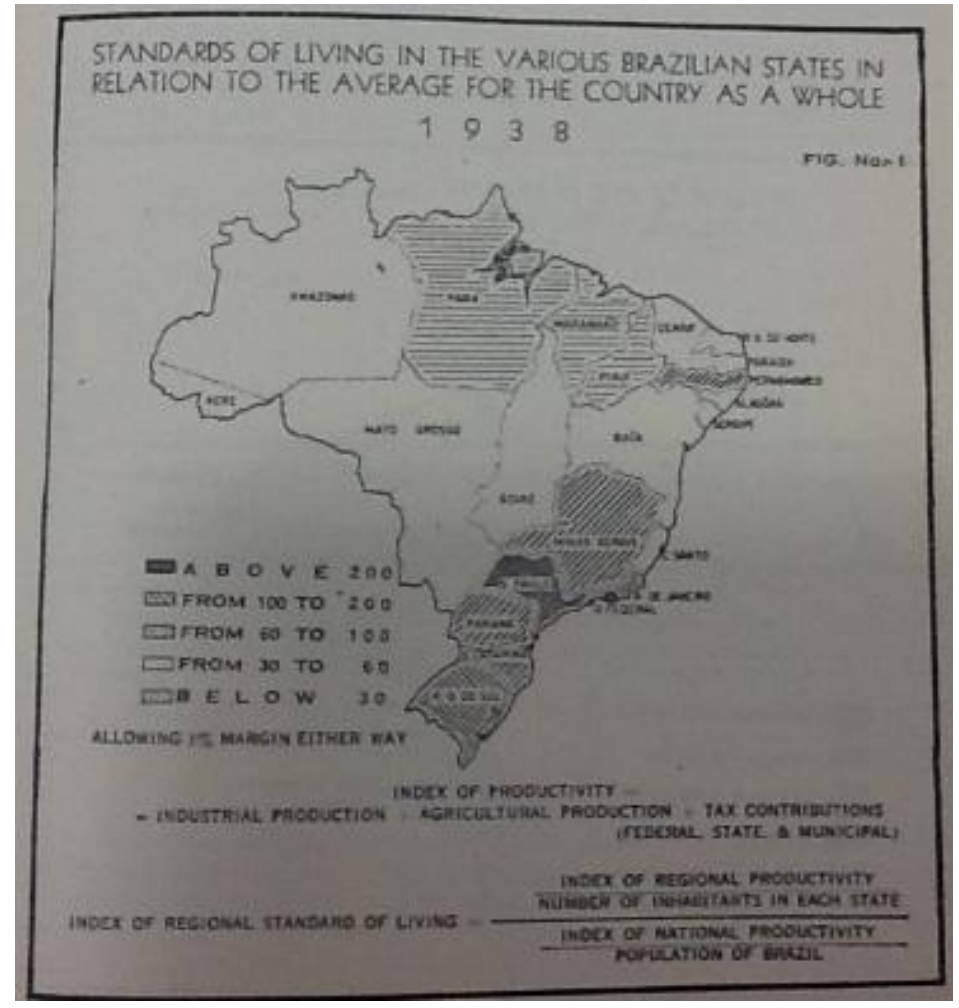

Figura 4. Mapa dos níveis de vida no Brasil, por região. Fonte: "Economic Resources and Population Shifts" (1940). ${ }^{308}$

Recapitulando o percurso até aqui, poderíamos dizer que Simonsen partiu de uma abordagem preocupada com questões mais restritas ao chão de fábrica, à organização do trabalho na empresa privada, rumo a uma perspectiva mais abrangente. Ao longo de seus

\footnotetext{
${ }^{307}$ SIMONSEN, 1940, p. 146-148.

${ }^{308}$ Versão traduzida do texto de Simonsen, publicada nos Anais do Oitavo Congresso Científico Norte-Americano (1940). O volume encontra-se na Coleção Roberto Simonsen.
} 
textos dos anos 1920-1930, foi forjando uma forma nacionalista de encarar os problemas econômicos. Esse nacionalismo construído nesse período apresenta um traço importante: a associação entre progresso da nação e desenvolvimento industrial, refletindo, no fundo, um projeto de classe. É durante o governo Vargas, e sobretudo no Estado Novo, que os industriais consolidaram sua participação efetiva na determinação dos rumos do país, por meio da participação direta na nova estrutura administrativa criada.

Era o momento de convencer o país de que desenvolvimento, progresso, melhoria de vida - tudo isso só seria possível com industrialização. Nessa trajetória, em que a defesa de interesses de classe está associada à formulação de um pensamento próprio, Simonsen mobilizou diversos referencias intelectuais. Nos primeiros anos, a influência maior foram as ideias de racionalização da produção e organização do trabalho, no âmbito de um projeto de modernização que passava . Ao longo dos anos 1920 e 1930, foi buscando outras referências, dentro e fora do Brasil. Não é possível filiar Simonsen a uma escola de pensamento específica - o que marca seu pensamento é a diversidade de influências. Diante de cada questão, Simonsen buscava mobilizar referenciais intelectuais variados, que dessem suporte a suas elaborações. Isso não significa, como vimos, que não houvesse uma busca por referências, no âmbito daquilo que circulava no Brasil e em ideias de difusão internacional. O caso do livro As crises no Brasil é um exemplo dessa busca, que era híbrida e seletiva. A argumentação de Aftalion sobre o caráter de crise de superprodução da depressão de 1930 foi referendada, ao passo que sua teoria da moeda, inovadora por questionar a teoria quantitativa, não foi mencionada. Três anos depois, Simonsen faria uso da teoria quantitativa da moeda para criticar a política monetária de Washington Luís.

Essa diversidade, todavia, não era sem sentido. O sentido era a busca por entender os entraves ao progresso do Brasil, sob a ótica de que esse progresso passaria, necessariamente, pela industrialização. Simonsen elabora, então, uma interpretação da história baseada na ideia de que os ciclos da economia primário-exportadora não seriam suficientes para promover o enriquecimento do Brasil, justamente por seu caráter cíclico: a riqueza é produzida e exportada, sem permanecer no país. Com a indústria, voltada para o mercado interno, seria diferente: trata-se de uma evolução necessária e promissora, causada pelos próprios desajustes da economia brasileira, que levam à depreciação cambial e à impossibilidade de se adquirir no estrangeiro os produtos demandados pelo Brasil. 


\section{Capítulo 3. Protecionismo e planejamento}

$\mathrm{O}$ pensamento econômico latino-americano do início do século $\mathrm{XX}$, especialmente no que se refere ao comércio internacional, era marcado pela prevalência das teses ricardianas relacionadas às vantagens comparativas, adaptadas por autores como John Stuart Mill e Alfred Marshall. Joseph Love considera que parecia haver uma correspondência entre bom desempenho econômico, dinamismo do setor exportador e a teoria das vantagens comparativas, de forma que a especialização da América Latina na produção de matériasprimas estava justificada. ${ }^{309}$

De forma muito resumida, a teoria das vantagens comparativas postula que haverá vantagens no comércio internacional, para ambos os países que o praticarem, mesmo que um deles seja mais eficiente em todos os setores da produção. Num modelo de dois países, partindo-se de uma situação de autarquia e havendo duas mercadorias cujos preços relativos são diferentes nas duas nações, haverá vantagem para cada uma delas se se especializarem em gêneros cuja produção é intensiva no fator abundante no país. A prática do comércio internacional levará, pois, a uma equalização na remuneração dos fatores de produção. Esta teoria, concebida originalmente por Ricardo, foi sofisticada pela análise marginalista, mas suas conclusões não diferem substancialmente das proposições iniciais.

$\mathrm{Na}$ América Latina, até meados do século XX, não havia formulação teórica alternativa à concepção das vantagens comparativas, com exceção, talvez, do Chile. Love argumenta que o crescimento das exportações chilenas de nitrato no final do século XIX lançou as bases para a constituição de um setor manufatureiro com relativa precocidade. Assim, surgiu uma entidade representativa industrial no país em 1883, fazendo-se uma defesa mais sofisticada da industrialização por meio das ideias de Friedrich List. No caso brasileiro, a defesa dos interesses da indústria no início do século $\mathrm{XX}$ se dava com base em argumentos que apelavam ao nacionalismo e ao patriotismo e por meio de reafirmações de que a indústria contribuía para o fisco e empregava um contingente ponderável da população, devendo portanto ser protegida, por exemplo, por tarifas. ${ }^{310}$

Três aspectos principais são destacados por Bielschowsky nas formulações pró-indústria de autores pré-1930, como Vieira Souto e Serzedelo Corrêa: ataque ao livre-cambismo, feito em tom nacionalista e anti-imperialista; ataque ao liberalismo, acompanhado de reivindicações de proteção aduaneira e medidas fiscais e tarifárias; e associação entre indústria e progresso ou prosperidade. A partir de 1930, haveria uma mudança qualitativa,

\footnotetext{
${ }^{309}$ LOVE, Joseph. "Economic ideas and ideologies in Latin America since 1930". IN: Cambridge Histories Online. Cambridge University Press, 2008.

${ }^{310}$ LOVE, 2008, pp. 393-402.
} 
pela própria transição econômica vivida pelo Brasil, mas ainda assim os reflexos disso, do ponto de vista das formulações econômicas, são limitados. As atenções voltaram-se para a industrialização, que se punha em curso com a crise do modelo agrário-exportador, o que não significava necessariamente fundamentação teórica consistente, nem articulação políticoideológica sólida em sua defesa. ${ }^{311}$

No cômputo geral, não parece haver muita dúvida de que o quadro traçado acima corresponda à realidade dos desenvolvimentos teóricos em economia levados a efeito num continente periférico como a América Latina. Na Europa e nos Estados Unidos, não parece haver, até as elaborações de Keynes após a Grande Depressão, avanços ou mudanças significativas nas formulações teóricas dominantes. Mesmo as formulações de Keynes só se traduzirão na chamada economia do desenvolvimento mais tarde. Considera-se como marco inicial da economia do desenvolvimento o artigo de Rosenstein-Rodan, "Problems of Industrialization of Eastern and Southeastern Europe", de 1943. ${ }^{312}$

Alguns aspectos do pensamento de Simonsen, todavia, matizam de alguma forma a visão esposada por historiadores como Love e Bielschowsky. Não se trata de recolocar o quadro geral de poucas formulações teóricas alternativas ao pensamento ligado ao livre-comércio, mas de apontar dois aspectos do pensamento de Simonsen - o protecionismo e o planejamento - que destoam desse esquema geral, pela apropriação original de ideias estrangeiras ou por articulações mais sólidas entre a referida interpretação de Simonsen para a história do Brasil e propostas de política econômica.

No caso do protecionismo, Simonsen se ligava, em texto do início dos anos 1930, à linhagem de pensamento protecionista, fazendo apropriações de autores como Friedrich List e Mihail Manoilescu, conhecidos divulgadores do protecionismo. Introduziremos, ainda, um autor russo, Wladimir Woytinsky, cujo trabalho de compilação de dados foi usado tanto por Manoilescu quanto por Simonsen para subsidiar o protecionismo como estratégia econômica. Em 1935, quando do debate parlamentar em torno do Tratado Comercial com os Estados Unidos, Simonsen, deputado classista, incorporou ao seu discurso, ainda que de forma seletiva e fragmentada, ideias de autores como os alemães Karl Rodbertus e Alfred Wagner. Nesse episódio, a defesa feita por Simonsen da industrialização diferenciou-se da de seus colegas industrialistas pelas apropriações de ideias de autores estrangeiros e pelo tipo de

\footnotetext{
${ }^{311}$ BIELSCHOWSKY, 2000, pp 248-249.

312 Ver ROSENSTEIN-RODAN, P. N. "Problemas da Industrialização da Europa do Leste e do Sudeste" [1943]. IN: AGARWALA, A. N. e SINGH, S. P. (orgs.) A economia do subdesenvolvimento. Rio de Janeiro: Contraponto/Centro Internacional Celso Furtado, 2010.
} 
argumento, mais ligado à história e à economia e de cunho menos moral. ${ }^{313}$

No que tange ao planejamento, destaca-se o debate, clássico na historiografia das ideias econômicas no Brasil, entre Roberto Simonsen e Eugênio Gudin - a chamada controvérsia do planejamento. Simonsen discutiu, no âmbito do Executivo federal, com Gudin, talvez o economista de orientação liberal mais influente à época. Na perspectiva de leitura adotada aqui, foi fundamental que Simonsen tivesse uma concepção histórica da evolução da economia brasileira, para que pudesse contrapor-se à visão tradicional das vantagens comparativas, segundo a qual caberia ao Brasil um tipo de inserção internacional específica determinado por seus setores mais produtivos, isto é, por seu setor agropecuário. O planejamento ganha condições de possibilidade como discurso e, sobretudo, como estratégia de política econômica se se admite que o problema econômico brasileiro - o atraso, ou o baixo desenvolvimento - é um fenômeno histórico, portanto em construção, e não uma questão de natureza alocativa, cuja resposta seria determinada a priori pela dotação natural de fatores. Se o problema for de natureza alocativa, a questão é deixar que os agentes invistam seus recursos nos setores mais remuneradores, isto é, os mais produtivos: não há a intenção, e nem a pretensão, de se modificar a estrutura econômica do país por meio do planejamento. Mostra-se também que Simonsen buscou referências teóricas externas em sua defesa da planificação econômica, estando em sintonia com uma forma de pensar o problema econômico do atraso a partir de suas especificidades históricas. Por fim, apresentam-se textos de Simonsen relativos ao período pós-Segunda Guerra, nos quais o autor sofistica sua argumentação relativa à inserção na divisão internacional do Brasil e, também, da América Latina, que surgia como categoria para se pensar os problemas econômicos.

\subsection{Simonsen e o protecionismo: momentos-chave}

Os argumentos protecionistas no Brasil, dentro do quadro esboçado de uma defesa pouco embasada teoricamente, não eram novos no tempo de Simonsen: eram utilizados pelo menos desde finais do Império e início da República, como bem demonstra a historiografia pertinente a este tema. Nícia Vilela Luz argumenta que o pensamento que orientou o movimento industrialista a partir da década de 1840 já apresentava um cunho mais nacionalista, ao defender uma política de proteção aduaneira com o objetivo de salvaguardar a independência econômica da nação: o principal personagem citado, ligado ao protecionismo dessa época é Manuel Alves Branco, autor da tarifa de 1844. Uma defesa mais organizada de

\footnotetext{
${ }^{313}$ Por argumento de cunho moral, entende-se aqui a ideia de uma defesa da indústria como setor econômico que traria benefícios à economia brasileira, em oposição ao discurso que afirmava ser a indústria maléfica por deslocar braços da lavoura ou por ser uma atividade artificial no Brasil.
} 
princípios protecionistas, todavia, não viria antes do último quartel do século XIX, com as reivindicações da indústria de chapéus do Rio de Janeiro, que passou a sofrer forte concorrência alemã. A presença dos industrialistas, a partir da década de 1870, quando apareceu a questão chapeleira, e as políticas protecionistas adotadas pelos Estados Unidos e pela Alemanha contribuíram para que a política tarifária começasse a ser questionada, juntamente com os interesses a quem servia. ${ }^{314}$

Com o advento da República, os industrialistas passaram a ganhar mais espaço, ocupando cadeiras no Congresso e participando diretamente das comissões de tarifas. A questão tarifária passou a estar mais presente na imprensa, à medida que a elite industrial se ampliava e passava a incluir diferentes profissionais (engenheiros, militares, industriais e parlamentares). A tarifa de 1895-96 é considerada por alguns a primeira tarifa protecionista, tendo sido elaborada sob pressão dos industrialistas. Foi revisada logo em seguida. A tarifa que perdurou durante boa parte da República Velha foi a de 1900, que não tinha intenção claramente protecionista, mas restabelecia a quota-ouro (medida que visava compensar os efeitos da desvalorização cambial sobre a arrecadação fiscal), não sendo de todo desfavorável à indústria. Foi, todavia, na década de 1930 que houve um maior fortalecimento do discurso protecionista, devido ao declínio do liberalismo econômico e às mudanças introduzidas no quadro político e estatal brasileiro, com a Era Vargas. Foi a década em que se tornaram influentes, no Brasil, as ideias de List e Manoilescu. A partir do final dos anos 20 e nos anos 30, os líderes da indústria, entre os quais Roberto Simonsen, Jorge Street, Otávio Pupo Nogueira, Vicente Galliez e Euvaldo Lodi formularam algo que se possa chamar uma política protecionista: seu objetivo seria utilizar a tarifa de forma racional, apoiando os setores considerados essenciais para a economia brasileira, incentivando a criação de setores de base e selecionando importações de modo a proteger o similar nacional. ${ }^{315}$

Vale mencionar que, na disciplina feita por Simonsen na Escola Politécnica de São Paulo, o programa tinha itens não exatamente favoráveis ao protecionismo. O item 14 da seção referente à "Circulação das riquezas" era sobre teoria do comércio internacional:

14. Theorias do commercio internacional. - A liberdade de commercio internacional é a regra geral. Restricções de ordem politica e ou moral; restricções determinadas pelo interesse fiscal. Exame da questão sob o ponto de vista dos interesses economicos. Tres escolas ou systemas: escola proteccionista $\mathrm{o}[\mathrm{u}]$ systema do protecionismo puro; escola livre-cambista ou systema da liberdade absoluta; theoria ecletica ou systema animador. Theoria da balança do commercio: falsas hypotheses

\footnotetext{
${ }^{314}$ Ver LUZ, 1975 [1960], pp. 50-53 e LEOPOLDI, 2000, pp. 100-102.

315 LEOPOLDI, 2000, pp. 103-110.
} 
em que se baseia. Erros e injustiças do protecionismo puro. Casos de razoavel animação á industria nacional; varios meios de animação. ${ }^{316}$

A leitura dos tópicos desse item de aula conduz à ideia de que, mesmo que fossem feitas concessões ao protecionismo em alguns casos, a liberdade de comércio seria a "regra geral". Ainda assim, tanto a liberdade absoluta quanto o protecionismo absoluto não recebiam um julgamento positivo. A "theoria ecletica" parecia merecer a melhor avaliação, pois seria esse o sistema "animador", isto é, fomentador da produção. Como vimos acima, o programa da disciplina de Economia Política da Politécnica de São Paulo era voltado para as questões do fomento à produção, veiculando um conhecimento aplicado de economia. Dessa forma, o ecletismo aparece como preferível: a postura protecionista deveria ser adotada em alguns casos, nos outros prevalecendo o livre-comércio - para cada situação, um tipo de abordagem. De toda forma, questionava-se a teoria da balança comercial favorável e admitia-se algum grau de animação à indústria nacional, mas pelo visto não pela via do protecionismo "puro". As discussões mais aprofundadas sobre protecionismo, que aparecem ao longo dos textos de Simonsen, vão além dessa ideia de uma proteção ocasional, da qual as nações deveriam lançar mão em momentos excepcionais, em que se devesse fugir à "regra geral" do livre-cambismo.

O protecionismo que procuramos estudar, em alguns momentos-chave da obra de Simonsen, reflete a busca por uma articulação teórica - ou, no dizer do próprio Simonsen, um embasamento científico - que justifique um protecionismo mais sistemático. Os textos analisados a seguir não se referem à defesa de tarifas que protejam a economia nacional da concorrência estrangeira - essa reivindicação é quase ubíqua na obra do autor e nos discursos industrialistas da época. A preocupação aqui passa pela difusão internacional de ideias: o enfoque é na apropriação de teorias do comércio internacional por Simonsen, a qual lhe permitiu fazer uma defesa do protecionismo baseada em argumentos teóricos, conformando elementos de um pensamento econômico protecionista brasileiro.

Dois autores estrangeiros são referências fundamentais quando se trata da forma como Simonsen abordou a questão do comércio internacional e do protecionismo: o alemão Friedrich List e o romeno Mihail Manoilescu. Esses economistas foram fundamentais para o pensamento protecionista brasileiro, inspirando Simonsen e seus contemporâneos. O tipo de influência exercida por cada um desses autores é distinto. List foi um economista do século XIX, cujos escritos já faziam parte do corpus da economia à época de Simonsen. Já Manoilescu era um contemporâneo: homem público atuante na Romênia, teve seu principal

\footnotetext{
${ }^{316}$ Programma da Quinta cadeira do terceiro anno do curso de engenheiros civis, quarta do terceiro anno dos cursos de engenheiros industriaes e architectos e quarta do segundo anno do curso de electricistas - 1913. Arquivo Histórico da Escola Politécnica. Fundo Escola Polytechnica (1892-1934). Caixa 19.
} 
livro, Teoria do protecionismo e da permuta internacional, traduzido no Brasil com patrocínio do CIESP, em 1931. No caso de List, a influência era acadêmica e ligada à tradição de se referir à sua obra como principal contraponto à economia de matriz ricardiana, ligada ao livre-cambismo. No caso de Manoilescu, houve uma apropriação mais consciente e direta das ideias: a sintonia entre o pensamento de Simonsen e as elaborações de Manoilescu, nesse sentido, é clara. Faremos uma breve apresentação dos argumentos desses dois autores, no que tange ao comércio internacional, para abordar em seguida o primeiro momento-chave escolhido da obra Simonsen, em que há um tratamento mais específico da questão do protecionismo, a Conferência no Mackenzie College de São Paulo, em 1931.

O principal argumento protecionista de List era que o livre comércio só seria benéfico para nações que se encontrassem em pé de igualdade, do ponto de vista de seu desenvolvimento industrial-manufatureiro.

Percebi claramente que a livre concorrência entre duas nações altamente civilizadas
só pode ser mutuamente benéfica no caso de ambas estarem em um grau de
desenvolvimento industrial mais ou menos igual; ao contrário, qualquer nação que,
em razão de reveses, estiver atrasada em relação a outras, do ponto de vista
industrial, comercial e naval, embora possua os meios mentais e materiais para
desenvolver-se, deve antes de tudo aumentar e consolidar seus próprios poderes
individuais para aparelhar-se a entrar na livre concorrência com nações mais
evoluídas. ${ }^{317}$

A partir de fatos históricos relativos a diversas nações, List mostrava que o protecionismo seria a única forma de colocar as nações atrasadas em pé de igualdade com a nação predominante. De acordo com o autor, os EUA, como ex-colônia inglesa, teriam todas as influências possíveis da chamada "escola cosmopolítica" - favorável ao livre comércio - mas viram-se obrigados, num contexto de guerra com a metrópole britânica, a manufaturar no país os bens anteriormente adquiridos via comércio internacional. A Grã-Bretanha, por seu turno, só teria adotado o livre-cambismo após proteger sua indústria nascente, quando seu setor manufatureiro já estava estabelecido; os britânicos estariam cientes de que o livre comércio beneficia, sobretudo, os produtores de manufaturas. Nesse sentido, o protecionismo não era, de acordo com List, produto de mentes especulativas, mas, sim, consequência natural da diversidade de anseios das nações por independência e poder. É de Friedrich List a metáfora da "indústria infante", que deveria ser protegida até que criasse condições de competir com as indústrias dos países avançados. ${ }^{318}$

Um ponto relevante sobre o pensamento de List e a sua recepção no Brasil e na América Latina foi destacado por Mauro Boianovksy. Os argumentos protecionistas do economista

\footnotetext{
${ }^{317}$ LIST, Georg Friedrich. Sistema nacional de economia política. [1841]. São Paulo: Abril Cultural, 1983. pp. $3-4$.

${ }^{318}$ Ver LIST, [1841] 1983, p. 85 e RODRIGUES, 2005, p. 54.
} 
alemão teriam sido pensados para industrializações retardatárias de países hoje centrais, a exemplo da Alemanha, mas não para países tropicais, haja vista que List dividia o mundo entre zonas "tropicais" ou "tórridas" e zonas "temperadas", devendo somente as últimas seguir a rota da industrialização. Os economistas latino-americanos do final do século XIX e primeira metade do XX teriam feito uma leitura seletiva de List, destacando os argumentos que lhes interessavam e deixando de lado ideias como a da divisão "climática" do mundo. Esse seria o caso de Simonsen, com seus argumentos de que a independência política e econômica das nações só seria alcançada na medida em que a indústria fosse protegida, acompanhando o desenvolvimento da agricultura. ${ }^{319}$ De fato, no capítulo 13 do Sistema Nacional, List deixava claro em quais países a produção manufatureira se desenvolveria de forma mais favorável.

Evidentemente, os países mais favorecidos pela natureza (...) são aqueles cujo solo
produz os bens de primeira necessidade mais comuns, da melhor qualidade e na
maior quantidade, e cujo clima for mais propício para o trabalho físico e intelectual.
- estes são os países localizados na zona de clima temperado. Com efeito, é nesses
países que prospera de modo peculiar a força manufatureira, mediante a qual a nação
não somente atinge o mais alto grau de desenvolvimento intelectual, social e
político, mas também adquire condições para fazer com que os países de clima
tropical e de civilização inferior dependam deles, até certo ponto. ${ }^{320}$

Friedrich List reforçava a ideia de equilíbrio ou harmonia das forças produtivas, tanto entre atividades intelectuais e braçais, quanto entre manufatura e agricultura. Numa alusão à fábrica de alfinetes de Adam Smith, uma nação que tem excesso de filósofos e de eruditos produziria cabeças de alfinete em demasia. Já uma nação sem manufaturas seria como um indivíduo dotado de apenas um braço. Nesse sentido, seria benéfico para o conjunto das nações internalizar a divisão do trabalho referida por Smith. ${ }^{321}$ Para qualquer nação, seria interessante assegurar-se de ter essa complementaridade entre os setores produtivos, porém, devido a questões naturais, as nações temperadas teriam chances maiores de obter êxito nesse processo. Não se infere de List que o desenvolvimento da manufatura seja uma atividade a ser recusada por nações tropicais e nem que possa ser maléfica para essas nações, mas tais atividades prosperariam com muito mais facilidade em países de clima temperado. A leitura feita pelos industriais brasileiros - e por Simonsen em particular - da obra de List privilegiava certos aspectos, em detrimento de outros, o que não significa que se tenha feito uma apropriação pouco coerente com os argumentos de List: houve, sim, uma apropriação seletiva.

\footnotetext{
${ }^{319}$ BOIANOVSKY, Mauro. "Friedrich List and the economic fate of tropical countries". IN: Social Science Research Network, 2011. p. 03 ep. 32.

${ }^{320}$ LIST, [1841] 1983, p. 114.

${ }^{321}$ LIST, [1841] 1983, p. 113.
} 


\subsection{1. "As finanças e a indústria": Manoilescu e Woytinsky}

No texto "As finanças e a indústria”, uma conferência proferida no Mackenzie College de São Paulo, em 8 de abril de 1931, Roberto Simonsen referia-se a List como aquele que

delineou o enriquecimento e a industrialização na Allemanha prégando a abolição das tarifas aduaneiras entre os trinta e nove estados que vieram a formar o Imperio Allemão, e a criação de barreiras proteccionistas para o exterior indispensaveis á formação industrial na sua phase incipiente. ${ }^{322}$

A referência a List era seguida de uma manifestação clara em favor do protecionismo alfandegário, como forma de apoiar as indústrias nacionais, fragilizadas pela crise econômica mundial dos anos 1930. Assim como a Alemanha fizera em finais do século XIX, o Brasil deveria reduzir impostos interestaduais e elevar as tarifas externas. Simonsen opunha-se, sobretudo, à reivindicação de que se mantivesse a orientação fiscal das tarifas, suprimindo seu caráter protecionista. A permanecer esse tipo de política, aumentariam os mercados externos para o café brasileiro, permitindo que crescessem as importações de produtos industriais. Simonsen considerava este argumento não apenas ingênuo, pois nações industrializadas como Alemanha, Inglaterra e Estados Unidos estavam aplicando políticas protecionistas para se defender da crise em curso no início dos anos 1930, mas, também, perigoso, por direcionar a opinião pública nacional contra as indústrias. ${ }^{323}$ Esse tipo de argumento de cunho livrecambista, Simonsen reconhecia, não era uma exclusividade do Brasil, sendo inclusive defendido pela maioria dos economistas, o que colocava o protecionismo numa situação singular.

O protecionismo offerece mesmo o aspecto de uma grande curiosidade dos tempos modernos: combatido teoricamente pela maioria dos economistas academicos, que prégam de preferencia o livre cambio, é elle adoptado no entanto, praticamente, pela totalidade dos paizes e cada vez de modo mais radical. ${ }^{324}$

A obra de Mihail Manoilescu seria, para Simonsen, uma demonstração dos fundamentos científicos do protecionismo: "Manoilescu faz notar que o interesse nacional, o verdadeiro criterio scientifico que deve prevalecer no estabelecimento de um systema de tarifas, resalta do estudo que se faça da productividade". ${ }^{325}$ A esta altura, Manoilescu era Ministro do Comércio e Indústria na Romênia, e sua obra era influente no Brasil e na península ibérica. Vale lembrar que a tradução e publicação do livro no Brasil dera-se por iniciativa do recémfundado Centro das Indústrias do Estado de São Paulo (CIESP). De acordo com Joseph Love, Manoilescu teria fornecido o argumento decisivo para que Otávio Pupo Nogueira, industrial e porta-voz do recém-fundado CIESP, se manifestasse contra a acusação, feita pelos

\footnotetext{
${ }^{322}$ SIMONSEN, 1931, p. 248.

${ }^{323}$ SIMONSEN, 1931, pp. 248-249.

${ }^{324}$ SIMONSEN, 1931, p. 249.

${ }^{325}$ SIMONSEN, 1931, p. 250.
} 
cafeicultores, de artificialidade da indústria de sacos de estopa, em razão de sua matéria-prima importada, a juta. Pupo Nogueira teria, então, se interessado por trazer a obra de Manoilescu para o Brasil. A tradução foi feita em 1931 e o livro deveria ser publicado com um prefácio especial para a edição brasileira, o que não aconteceu, pois o CIESP não conseguiu fornecer os dados estatísticos necessários a Manoilescu. ${ }^{326}$

Simonsen destacou alguns aspectos centrais da teoria de Manoilescu: a ideia de que o lucro nacional é mais importante que o lucro individual e o argumento de que deveriam ser incentivados (ou protegidos) os setores com "coeficiente de qualidade" mais elevado, sendo este coeficiente uma medida da produtividade, em sentido absoluto. ${ }^{327}$ Uma ideia geral da teoria apresentada por Manoilescu, em seu livro Teoria do protecionismo, ajudará a clarear o sentido da apropriação feita por Simonsen, bem como o cruzamento da teoria do comércio internacional com os subsídios quantitativos fornecidos por Wladimir Woytinsky, outro economista coevo cuja obra será analisada mais adiante.

O argumento central de Manoilescu era que não é a produtividade relativa (ou os preços relativos, vistos como reflexo da produtividade) que deve ser levada em conta ao se mensurar as vantagens do comércio internacional, mas, sim, a produtividade absoluta. Qualquer atividade que elevasse a produtividade média da nação deveria ser instalada, sendo irrelevante a comparação com o estrangeiro. Importava, sobretudo, elevar a produtividade média do país. Usando o exemplo clássico de Ricardo, Manoilescu insistia que pouco importa que a indústria têxtil da Inglaterra fosse mais produtiva que a de Portugal: o resultado teórico era que os dois devem se especializar em panos, pois a indústria em um determinado país é, via de regra, mais produtiva do que a agricultura neste mesmo país (obtém-se mais produto por unidade de trabalho ou capital empregado). Para se tornar mais produtivo, portanto, e auferir maior lucro nacional um país deve se industrializar cada vez mais, transferindo recursos da agricultura, setor pouco produtivo, para a indústria, setor mais produtivo, ainda que para isso tenha de proteger os setores industriais novos, menos competitivos do que a indústria estrangeira.

À indagação sobre a possibilidade de importar a custos menores, já que a indústria estrangeira pode ser mais produtiva, Manoilescu respondia com a ideia de mercadoria de permuta. Para importar algo, um país deve dar em troca (ou vender para obter divisas) mercadorias de permuta, as quais, geralmente, são produzidas em condições menos sofisticadas, ou menos produtivas, do que aquelas em que se produz a mercadoria importada. A proteção, portanto, se justifica sempre que o setor que se deseja instalar operar com produtividade mais elevada do que os setores nos quais são produzidas as mercadorias de

\footnotetext{
${ }^{326}$ LOVE, 1998, pp. 339-340. Ver também a “Apresentação da Edição de 1931”, IN: MANOILESCU, [1931] 2011.

${ }^{327}$ SIMONSEN, 1931, p. 251.
} 
permuta, usadas na importação. Isso garante que se eleve a produtividade média da nação e, por conseguinte, seu lucro nacional. ${ }^{328}$

Esta recapitulação esquemática pretende destacar o seguinte ponto: é fundamental, para esta teoria do comércio internacional, que, de modo geral, os setores que se deseja instalar no país sejam mais produtivos que os setores já existentes, ou no caso dos países atrasados, a indústria seja mais produtiva que a agricultura. A Primeira Parte do livro de Manoilescu é dedicada a mostrar, com dados tomados, sobretudo, de Wladimir Woytinsky, a superioridade, em termos de produtividade, da indústria sobre a agricultura. "Do exposto, resulta que, para os países agrícolas e atrasados, há maior vantagem relativa em passar das ocupações agrícolas às ocupações industriais. $" 329$

Vale observar que o livro do qual Manoilescu retira os dados com os quais elabora seus índices que mostram a superioridade da indústria sobre a agricultura é Die Welt in Zahlen $(O$ mundo em números), um compêndio de dados econômicos, em sete volumes, elaborado por Wladimir Woytinsky e sua esposa, Emma Woytinsky, na década de 1920, período em que estiveram na Alemanha. ${ }^{330}$ Simonsen referiu-se a Woytinsky nos seguintes termos: "De acordo com Woytinski o rendimento liquido da industria, excluindo mesmo a mineração, é mais forte que o rendimento liquido da agricultura na Inglaterra, Estados Unidos, Allemanha, França, Belgica, Suissa, Hollanda e Australia, isto é, nos mais ricos paizes do mundo.”331 Embora Simonsen não cite a fonte dessa informação, os inícios apontam que ela provém da Teoria do protecionismo, de Manoilescu. Compare-se o trecho de Simonsen com a nota 40, da Primeira Parte do livro de Manoilescu: "Segundo Woytinsky (vol. I, p. 159), a renda líquida total da indústria (sem as minas) é maior do que a renda líquida total da agricultura nos seguintes países: Inglaterra, Estados Unidos, Alemanha, França, Bélgica, Holanda, Suíça, Canadá e Austrália (igualdade)". ${ }^{332}$ Não parece haver dúvida de que Simonsen retirou do livro de Manoilescu essas informações compiladas por Woytinsky.

Para além dessas referências textuais cruzadas, convém sublinhar o caráter fundamental, para Simonsen e Manoilescu, da associação entre indústria e riqueza, entre industrialização e progresso ou superação do atraso. É nesse sentido que Simonsen buscou os dados de Woytinsky, provavelmente por meio da obra de Manoilescu cuja tradução patrocinada pelo CIESP ele mesmo prefaciara. O trabalho estatístico de Woytinsky teve a importância de dar

\footnotetext{
${ }^{328}$ MANOILESCU, [1931] 2011, "Segunda Parte-A teoria".

${ }^{329}$ MANOILESCU, [1931] 2011, p. 46.

${ }^{330}$ WOYTINSKY, 1961, pp. 451-454.

${ }^{331}$ SIMONSEN, 1931, p. 224. Ver também FANGANIELLO, 1970, pp. 135-136. A autora faz um panorama dos principais argumentos defendidos por Simonsen neste texto, destacando os autores citados pelo autor.

332 MANOILESCU, [1931] 2011, p. 204. "Notas e referências".
} 
corpo, por meio de dados quantitativos, à ideia, fundamental para a teoria do comércio internacional em questão aqui, de que a indústria é mais produtiva do que as atividades primárias, sendo, portanto, a opção mais vantajosa para que os países atrasados pudessem elevar seu lucro nacional.

No plano intelectual, é clara, no texto de 1931, a preocupação em justificar, por meio da referência a autores coevos, a defesa da indústria. A assimilação da teoria da permuta internacional advogada por Manoilescu e empiricamente reforçada pelas constatações de Woytinsky foi um aporte importante, para que a defesa dos interesses industriais ganhasse o status de um projeto intelectualmente coerente e teoricamente benéfico para a nação: neste momento, era colocada de forma muito clara por Simonsen a associação entre indústria e progresso nacional, implícita na ênfase, dada por Manoilescu, no lucro nacional, ou seja, na produtividade média do país, que se elevaria com a instalação de atividades industriais de qualquer tipo. Vale lembrar que, do ponto de vista institucional, Simonsen passou a ocupar uma posição mais destacada de porta-voz da indústria. O lugar de vice-presidente da FIESP lhe assegurava destaque público e um vínculo mais claro com os interesses específicos da indústria.

As sintonias entre Simonsen e Wladimir Woytinsky não se resumem a esta citação, articulada à defesa de uma teoria protecionista do comércio internacional. Alguns elementos da trajetória biográfica e intelectual deste autor podem ajudar a reconstruir esse ambiente internacional de difusão de ideias econômicas do qual faziam parte Simonsen, Manoilescu e o próprio Woytinsky. Nascido na Rússia em 1885, W. Woytinsky foi membro do Partido Social-Democrata Russo. Inicialmente bolchevique, tornou-se menchevique durante a Primeira Guerra. Em 1917, foi membro do Comitê Executivo Central de Soviets e editor da revista Izvetsia. Foi preso pelos bolcheviques, tendo-se exilado na Geórgia após ser solto. Trabalhou como representante diplomático da Geórgia até o país ser encampado pela URSS, em 1922. Woytinsky se instalou, então, na Alemanha da República de Weimar, onde permaneceu até a ascensão do nazismo, em 1933, quando partiu para a Suíça e para os Estados Unidos, onde viveu até 1960. Suas obras mais influentes e conhecidas nos EUA são World Population and Production (1953) e World Commerce and Governments (1955) ${ }^{333}$. São grandes coleções de dados econômicos e políticos, que Woytinsky compilou e interpretou, em coautoria com sua esposa, Emma Woytinsky.

\footnotetext{
${ }^{333}$ Não há espaço aqui para uma biografia mais extensa de Wladimir Woytinsky. Sua autobiografia, Stormy Passage, fornece grande variedade de dados sobre sua trajetória de vida. Ver WOYTINSKY, 1961. Sobre a trajetória dos mencheviques russos e uma curta biografia de Woytinsky, ver LIEBICH, André. From the other shore: Russian social-democracy after 1921. Cambridge (Massachusets): Harvard Universiy Press, 1999. p. 341.
} 
Em seu livro Estados Unidos da Europa, ${ }^{334}$ publicado em alemão em 1926 e em francês em 1927, Wladimir Woytinsky, expunha seu projeto de reconstrução da Europa no pósPrimeira Guerra. Esse processo deveria passar pela unificação política e econômica do continente, de modo a permitir uma integração que evitasse uma escalada de autoritarismo e violência, que fatalmente levaria a novos conflitos bélicos. A ideia é que o principal objetivo a ser atingido deveria ser a estabilidade econômica. "Eis o caminho que conduz à segurança da Europa: ele passa pela economia e, antes de tudo, pelo estudo da evolução econômica"335.

O texto de Simonsen "As finanças e a indústria" está dividido em três seções: introdução, “A racionalização Allemã" e "A Politica Industrial no Brasil”. Simonsen discutiu a industrialização alemã de forma geral e a capacidade que o país tivera de se recuperar da Primeira Guerra e da espiral inflacionária dos anos 1920. Não se deteve tanto sobre a conjuntura europeia, como fizera Woytinsky. Isso não impede que suas propostas se aproximassem das defendidas por Woytinsky, tanto em seu livro de 1927, quanto em seu plano de ação econômica contra a crise alemã, que será discutido mais adiante.

O argumento central de Simonsen, na seção referente à "racionalização allemã", era que a Alemanha, profundamente atingida pela guerra e pela inflação de 1923-24, teria conseguido se reintegrar à economia mundial como uma potência por meio da inteligência e do trabalho. É esse esforço que orienta a racionalização, cujos objetivos seriam o abaixamento do custo e aumento da qualidade na produção industrial. ${ }^{336}$ Simonsen ressalta que as duas grandes manifestações exteriores da racionalização alemã seriam a "fabricação contínua" (o fliessende Arbeit) e a concentração das empresas.

\footnotetext{
A fabricação continua, fliessende arbeit, comprehende o systema de producção que, tendo o trabalho em transportador como base, abrange a padronização dos typos e a especialização das usinas sob a formula geral de produzir accelerando o escoamento do capital circulante. ${ }^{337}$
}

Trata-se aqui de uma evolução do sistema fordista que compreenderia, além da linha de montagem, uma padronização dos estabelecimentos produtivos, cujo objetivo principal seria a redução do custo de produção por meio da diminuição daquilo que Simonsen chama de "valor do produto em curso de fabricação", que é parte do capital circulante. O fliessende Arbeit teria como objetivo principal acelerar a rotação do capital circulante, de forma a diminuir a necessidade de seu emprego, favorecendo assim uma redução de custo. ${ }^{338}$ Sobre esse aspecto, Simonsen conclui que "os dispositivos de Ford soffreram alterações apreciaveis na

\footnotetext{
${ }^{334}$ O livro a que tivemos acesso é a edição francesa de 1927, intitulada Les États Unis d'Europe.

${ }^{335}$ WOYTINSKY, 1927, p. 09.

${ }^{336}$ SIMONSEN, 1931, p. 234.

${ }^{337}$ SIMONSEN, 1931, p. 237.

${ }^{338}$ SIMONSEN, 1931, p. 238.
} 
Allemanha, onde a sciencia ao serviço do espirito meticuloso da raça conseguiu combinações e modalidades interessantissimas". ${ }^{339}$ O outro aspecto da racionalização se refere à concentração das empresas em Konzerne, que ocorreria por motivos, acima de tudo, financeiros: sendo o capital para investimento escasso num país devastado pela guerra, era necessário que as firmas economizassem recursos, por meio da eficiência produtiva e do usufruto de economias de escala.

Vale destacar aqui duas questões, relativas à industrialização alemã, que mostram que Simonsen e Woytinsky estavam num mesmo campo de discussão, tentando pensar em formas de intervenção sobre a economia, que levassem ao desenvolvimento industrial e à superação de entraves: a primeira questão se refere à forma de se estimular a economia alemã/europeia e a segunda, à unificação europeia.

\begin{abstract}
Num povo que perdeu pela guerra e pela inflação seus capitaes e rendas, é na massa dos salarios que reside quase que unicamente a criação do poder aquisitivo do mercado consumidor interno. Dahi a justificação da politica de altos salarios conjuntamente com a baixa do preço de custo, com o duplo intuito de criar maior poder aquisitivo e intensificar o consumo incrementando o escoamento dos productos industriaes. ${ }^{340}$
\end{abstract}

As duas formas de atacar o problema alemão, para Simonsen, eram a diminuição do custo de produção, por meio da referida racionalização produtiva, do lado da oferta, e o incremento do poder aquisitivo dos trabalhadores, por meio de uma política de altos salários, do lado da demanda. Alguns anos antes, Woytinsky discutira as saídas para a Europa pós-Primeira Guerra, no referido livro Estados Unidos da Europa, de 1927. A terceira parte do livro, intitulada "À procura de uma saída", discute propostas para dinamizar a economia do continente. As duas primeiras seções dessa parte, que é uma coletânea de propostas para reaquecer a economia são: "A diminuição dos custos de produção" e "O aumento do poder de compra da população". São justamente as duas estratégias defendidas por Simonsen para o caso alemão.

Em seu livro, Woytinsky começava por recusar a redução de salários como forma de se reduzir custos. "O abaixamento do preço de custo a expensas dos trabalhadores enfraquece o poder de compra interior do país. Essa política contribui para retração dos mercados internos e

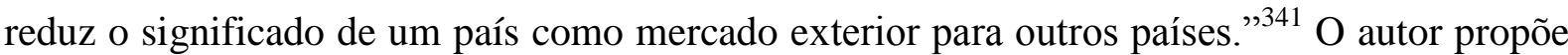
que se reduzam os custos de produção por meio de quatro medidas que deveriam melhorar as condições da indústria europeia, a qual, segundo ele, desperdiçava considerável quantidade de trabalho. As medidas sugeridas para diminuir custos são: aumento da qualidade do trabalho,

\footnotetext{
${ }^{339}$ SIMONSEN, 1931, p. 240-241.

${ }^{340}$ SIMONSEN, 1931, p. 240.

${ }^{341}$ WOYTINSKY, 1927, p. 95.
} 
por meio da formação profissional; política racional de habitação, visando à redução dos aluguéis; política alfandegária visando a diminuição dos direitos de entrada de itens básicos e de matérias-primas industriais; e política de unificação europeia. ${ }^{342}$

A política de altos salários, que Woytinsky considerava como amplamente difundida nos Estados Unidos, mas ainda pouco empregada na Europa, se justificava pelo aumento do poder de compra da população e consequente restabelecimento do dinamismo da economia.

Nesse caso [uma crise de subconsumo], uma elevação metódica dos salários conduz, no final das contas, não ao incremento, mas à diminuição dos preços por unidades das mercadorias, pois que essa elevação salarial aumenta e garante a demanda dos produtos industriais e permite, por conseguinte, o restabelecimento da produção, na amplitude do poder produtivo da indústria. ${ }^{343}$

Woytinsky voltava seu olhar para o lado da demanda e, diagnosticando o problema europeu como de subconsumo, propunha uma política de altos salários como forma não só de aquecer a economia, mas, também, de diminuir os custos de produção, já que uma demanda aquecida favoreceria o restabelecimento da indústria em suas condições normais, isto é, usufruindo de economias de escala e de uma demanda garantida, apoiada no alto poder de compra dos salários. Woytinsky colocava a demanda em primeiro plano: havendo uma demanda garantida, a oferta existiria também sem maiores fricções, o que eliminaria possíveis situações de carestia de produtos e aliviaria as pressões sobre os preços.

Sobre essas questões, Simonsen fez uma conexão interessante entre economias de escala, organização produtiva e a questão da unificação europeia. Referindo-se aos Konzerne alemães, salienta:

\begin{abstract}
Essas concentrações da produção formadas dentro do systema da racionalização, em que a produção em grande massa, os baixos preços de custo e os altos salários são directrizes a serem observadas, têm o efeito de evitar perturbações no mercado productor e impedir superproduções geradas pelas concorrências que muitas vezes occasionam crises. Trazem ainda o aproveitamento mais eficiente da mão de obra, o estudo dos verdadeiros interesses dos mercados, supprimindo produções inuteis e trabalhos em pura perda. A racionalização comprehende, portanto, idéas motrizes que formam como que uma "economia dirigida". (...) É natural que uma industrialização levada a um grande desenvolvimento procure uma expansão além de suas fronteiras e dahi os carteis internacionaes de que a Allemanha tem tido a iniciativa no continente europeu e que evoluem para a formação de grandes "trusts" internacionaes que só podem concorrer para a approximação dos povos e para a formação do bloco econômico europeu. ${ }^{344}$ (grifos nossos)
\end{abstract}

A concentração das indústrias era, então, parte do processo de racionalização, que envolveria baixo custo de produção aliado a altos salários. O resultado disso seria uma forma de produção que poderia usufruir de economias de escala e de demanda garantida. No fundo,

\footnotetext{
${ }^{342}$ WOYTINSKY, 1927, p. 99.

${ }^{343}$ WOYTINSKY, 1927, p. 103

${ }^{344}$ SIMONSEN, 1931, p. 243.
} 
todo esse esforço que Simonsen chamava de racionalização é uma estratégia de planejamento, isto é, uma forma de se reduzir as incertezas inerentes à produção capitalista, por meio da organização/padronização de processos e da criação de uma demanda pujante e garantida. Woytinsky enfatizava a criação de uma massa de salários que garantisse a colocação da produção no mercado; Simonsen reunia, em torno da ideia de "sistema de racionalização", a política de altos salários, os baixos custos e a produção em massa, com o fito de impedir a superprodução, isto é, o desajuste entre oferta e demanda. Tratava-se de organizar e planejar para reduzir os desequilíbrios do sistema.

$\mathrm{Na}$ medida em que esse tipo de planejamento se alastrasse pelo continente europeu, a consequência seria uma "aproximação dos povos", isto é, uma coordenação, em nível supranacional, dessa "economia dirigida". É para essa direção que apontam as propostas de Woytinsky para a Europa do pós-Primeira Guerra. Seu livro de 1927 era, na verdade, um chamado aos países europeus para que adotassem políticas de unificação econômica: o próprio título - Estados Unidos da Europa - associa-se à ideia de se fazer da Europa uma grande federação.

$\mathrm{O}$ que os dois autores pretendiam era elevar a produtividade nacional por meio da racionalização produtiva, da coordenação: se efetuado por cada país isoladamente, esse processo não funcionaria, pois a exportação é parte da demanda e as importações são parte da oferta de uma economia nacional. Se não houvesse um esforço conjunto de coordenação, a garantia de que a indústria teria sua produção demandada ficaria enfraquecida, a ideia de uma "economia dirigida", capaz de garantir uma estabilidade ao capitalismo industrial, não seria possível. Nesse sentido, Woytinsky e Simonsen convergiam na questão da importância de um esforço maior de coordenação para se resolver a questão alemã/europeia, que culminaria com um processo de unificação econômica (e política, para Woytinsky).

Levando em conta que a discussão feita por Simonsen nesse texto estava informada pela teoria do comércio internacional de Manoilescu, que pressupõe que todas as nações devem atingir os níveis mais elevados na escala de produtividade, mesmo que isso acarrete a necessidade de proteção, a preocupação com as políticas de unificação internacional se tornava mais urgente. Ora, o resultado, no limite, do esquema teórico protecionista é que todas as nações internalizariam, via proteção, todos os setores industriais mais produtivos, levando a uma situação de autarquia generalizada: para garantir a continuidade do comércio internacional, dentro do modelo de Manoilescu, seria necessário adotar algum tipo de coordenação e integração em nível internacional, para que os países não se fechassem totalmente. Parece incoerente fazer a defesa do protecionismo e propor políticas de 
coordenação comercial e produtiva em nível internacional. Embora Simonsen não propusesse isso explicitamente, essa contradição pode-se resolver com a adoção, num arranjo do tipo união aduaneira (como foi o Zollverein alemão), de uma tarifa externa comum, que seja protecionista com relação à produção fora da união aduaneira e, ao mesmo tempo, favoreça as trocas comerciais no interior da união, por meio da redução de barreiras internas.

É claro que Simonsen estudava o caso alemão para chegar, no final de sua conferência, à industrialização brasileira, mas essas convergências com W. Woytinsky dão mostra de que a elaboração simonseniana está inserida nesse ambiente de história das ideias, em que se buscavam medidas de estímulo à demanda, de proteção à indústria e de racionalização produtiva, para a superação dos problemas econômicos. Para além das contribuições presentes no livro de 1927, Woytinsky atuou, alguns anos depois, junto ao Partido Social-Democrata Alemão no contexto da Grande Depressão. O estudo dessa atuação ajudará a compor melhor o ambiente de ideias de que se trata aqui.

Em seu período na Alemanha, Woytinsky esteve envolvido, no âmbito da Confederação Geral Sindical Alemã (ADGB, na sigla original), ${ }^{345}$ com a elaboração de um programa para debelar os reflexos da Grande Depressão na Alemanha, em 1929-30. Woytinsky tinha uma proposta de estímulo à demanda para salvar a economia alemã, e essa proposta esbarrou na ortodoxia marxista vigente. Essa discussão de política econômica se inseria num contexto em que as economias ocidentais centrais lidavam com o dilema de como dar uma resposta à crise: as alternativas de política à disposição foram, em alguma medida, colocadas em questão.

De acordo com Peter Gourevitch, os receituários de política econômica disponíveis no momento eram: de um lado a ortodoxia livre-cambista e deflacionista e, de outro, os marxistas. $\mathrm{O}$ argumento de Gourevitch é que estas alternativas eram pouco exequíveis, do ponto de vista político: uma classe tomaria para si todas as vantagens, em detrimento da outra, caso uma delas fosse seguida. Na opção deflacionista, o estímulo à economia deveria vir do lado da oferta, por meio da redução dos custos de produção. Altos salários desencorajariam o investimento e a produção: a solução para a crise passaria, portanto, por uma transferência de renda dos trabalhadores para a classe capitalista, deteriorando as condições de vida, já pioradas pela crise, da classe trabalhadora. Por outro lado, ao adotar-se a solução coletivista, os capitalistas seriam expropriados dos meios de produção. Em suma, eram alternativas muito pouco factíveis, do ponto de vista político e social, na maioria dos países ocidentais. ${ }^{346}$

Duas alternativas colocavam-se, então, para o encaminhamento da crise. A primeira,

\footnotetext{
${ }^{345}$ Esta instituição - o Allgemeiner Deutscher Gewerkschaftsbund - foi a confederação sindical alemã durante a República de Weimar. Fundado em 1919, o ADGB existiu até 1933, com a proibição dos sindicatos pelo regime de Hitler.

${ }^{346}$ GOUREVITCH, Peter. Politics in hard times. London: Cornell University, 1986. pp. 127-131.
} 
chamada por Gourevitch de "neo-ortodoxia" misturava elementos de protecionismo com um tipo de mercantilismo. Baseava-se na desvalorização cambial, em tarifas e na regulação do mercado. A segunda alternativa consistia no estímulo à demanda, isto é, faziam-se déficits públicos para gastar com obras e transferências de renda. Esta segunda alternativa representava uma ruptura mais substancial com as os receituários vigentes. A Inglaterra teria seguido a primeira alternativa, inovando pouco em termos de política econômica. Já a Alemanha, já sob governo nacional-socialista, seria o país que mais fielmente perseguiu políticas de deliberado estímulo à demanda. A realização dessas duas linhagens de política econômica foi muito mais complexa do que o esquema deixa transparecer, como reconhece o próprio autor. Essa complexidade reside nas conexões entre economia, política e sociedade. O tipo de política adotado por cada país dependia do acordo possível entre capitalistas, trabalhadores e produtores rurais e em nenhum dos casos fez-se uma escolha por apenas uma dessas duas alternativas "ideais" mencionadas por Gourevitch. O que houve foram combinações dessas alternativas.

O plano de Woytinsky, inserido no âmbito alemão dessa discussão maior de alternativas de política econômica, baseava-se em gastos públicos com obras e num "reflacionamento" controlado, com o objetivo de aquecer a economia. Em sua autobiografia, Woytinsky tenta explicar as propostas daquilo que ficou conhecido como "política econômica ativa":

[A política econômica ativa] era construída em torno de duas ideias - obras públicas e o suporte dos preços através de créditos bancários para financiar essas obras. A segunda proposta implicava gasto público e desequilíbrio orçamentário não somente como meio de financiar obras públicas, mas também como veículo para se injetar poder de compra no sistema econômico anêmico e reverter a espiral deflacionária. ${ }^{347}$

A ideia de usar o desequilíbrio orçamentário como forma de conscientemente estimular a demanda tinha, provavelmente, um caráter inovador, no contexto de 1929-30. Woytinsky tenta esclarecer, algumas linhas adiante, as ideias que o teriam influenciado na elaboração deste plano:

\begin{abstract}
Naquele momento, eu ainda não era familiarizado com os trabalhos iniciais de Keynes, que teriam me ajudado no desenvolvimento de meus argumentos. Mas nos relatórios sobre política do ouro da Seção Financeira da Liga das Nações, encontrei a resposta para o problema. Um aumento moderado no poder de compra ou na moeda em circulação elevaria o nível de preço ou interromperia o seu declínio, encorajando a expansão da produção, sem o perigo de uma depreciação descontrolada da moeda. Em parte sob a influência desses relatórios, decidi apresentar meu plano em termos de uma política internacional contra a crise mundial. $^{348}$
\end{abstract}

Segundo o próprio autor, não teriam sido as propostas keynesianas que o teriam

\footnotetext{
${ }^{347}$ WOYTINSKY, 1961, p. 464. Os trechos de obras de Woytinsky aqui citados são traduções livres dos trechos originais em inglês, no caso do livro Stormy Passage, de 1961, e em francês, no caso de Les États Unis de l'Europe, de 1927.

${ }^{348}$ WOYTINSKY, 1927, p. 464.
} 
influenciado, mas, sim, os relatórios da Liga das Nações ${ }^{349}$ : assim como no caso de Simonsen, seu pensamento parece ter sido formulado na prática, sem a filiação consciente a um tipo de linhagem teórica. Em 1928, formou-se, na Liga das Nações, a Gold Delegation, que deveria debruçar-se sobre a questão da escassez nas reservas mundiais de ouro e sobre o impacto negativo que isso teria sobre os preços mundiais ${ }^{350}$. Quanto aos relatórios da Gold Delegation, vale mencionar que o Segundo Relatório Preliminar, publicado em janeiro de 1931 e escrito em meio ao pânico da crise que se iniciara em 1929, não continha menção alguma à crise econômica. ${ }^{351}$

Já no Relatório Final (1932), embora a Gold Delegation afirme que seu objetivo não é estudar a depressão corrente, apresenta um diagnóstico ortodoxo da crise. Baseado em teorias de equilíbrio de preços, o Relatório argumentava que a Depressão teria sido causada por fatores exógenos, tais como a inflação durante e após a Primeira Guerra, a gastança governamental e as rigidezes de preço. Todavia, Patricia Clavin identifica posições divergentes, colocadas em notas ao Relatório Final. A primeira nota é de Albert Janssen, Robert Mant e Henry Strakosch; a segunda é de Gustav Cassel. A argumentação presente nessas notas - ou no "relatório da minoria", como ficou conhecido - era que fatores monetários, como a má distribuição das reservas mundiais de ouro, teriam, sim, contribuído para a crise. A conclusão era que uma reforma monetária, juntamente com um programa de expansão creditícia, seriam o remédio adequado para a depressão. ${ }^{352}$ Os relatórios referidos por Woytinsky - e que o teriam influenciado na elaboração de seu plano de política econômica - parecem de fato apresentar, ainda que marginalmente, elementos que dessem ensejo para que o autor formulasse seu plano de reflacionar a economia alemã, por meio de obras públicas, do crédito e do moderado aumento no numerário circulante.

A ideia de que o aumento na moeda em circulação "elevaria o nível de preço ou interromperia seu declínio" estava ligada à concepção, convencional na economia desde os clássicos, de que um aumento de numerário circulante se reflete em preços. $\mathrm{O}$ aspecto não usual do argumento consiste em propor que o Estado adote deliberadamente esse tipo de política inflacionária, fazendo déficit orçamentário financiado por emissões, com vistas à construção de obras públicas. O Estado deveria gerar inflação para combater a espiral deflacionária. Isso certamente não seria bem recebido numa Alemanha ainda traumatizada

\footnotetext{
${ }^{349}$ A Liga das Nações, órgão de cooperação internacional criado após a Primeira Guerra, existiu, formalmente, de 1919 a 1946.

${ }^{350}$ CLAVIN, Patricia. “'Money talks' - Competition and cooperation within the League of Nations". IN: FLANDREAU, Marc. Money doctors: the experience of international financial advising 1850-2000. New York: Routledge, 2003. p. 224. Vale lembrar que este momento está inserido no curto período de vigência do padrão-ouro no entreguerras, de 1926 a 1931.

${ }^{351}$ CLAVIN, 2003, p. 225.

${ }^{352}$ CLAVIN, 2003, pp. 225-226.
} 
pelas consequências da hiperinflação do início dos anos 1920.

De fato, a proposta era muito arriscada para ser aceita, inclusive nos círculos da esquerda. Embora houvesse alguma simpatia pela ideia das obras públicas entre as lideranças do Partido Social-Democrata Alemão (SPD), a memória da hiperinflação ainda era viva e a liderança intelectual de Rudolph Hilferding, que se opunha ao plano, era inquestionável. Ainda seguindo as memórias de Woytinsky, o conflito de ideias entre W. Woytinsky, que elaborara seu plano no âmbito do ADGB, e Hilferding, se agravou quando da desvalorização da libra pelo Reino Unido, em julho de 1931. Nessa ocasião, o conselho do ADGB se reuniu para ouvir Hilferding sobre a desvalorização britânica. Nas palavras de Woytinsky:

Perguntei a Hilferding: "Como a desvalorização da libra vai afetar o desemprego na Inglaterra?'

“O desemprego vai aumentar”, ele respondeu sem hesitar. (...)

Então eu disse a Leipart [líder do ADGB] “(...) Hilferding fez sua previsão. Eu arriscarei a minha: a Grã-Bretanha atravessou um marco. Seu crédito será reforçado, outros países seguirão seu exemplo e depreciarão suas moedas. As exportações britânicas crescerão, sua produção se expandirá e seu desemprego declinará. A GrãBretanha está saindo da crise!".353

Com o cuidado que se tem de ter com uma fonte que representa o ponto de vista de apenas um dos interlocutores no debate, a passagem é interessante por mostrar o impacto, sobre os formuladores de ideias econômicas, de um evento de ruptura como foi a desvalorização britânica de 1931, que significou um passo importante na direção da desagregação do padrão-ouro, no bojo do processo de declínio da predominância mundial britânica. De fato, a previsão de Woytinsky se verificou e a economia do Reino Unido se recuperou, como de resto várias economias se recuperaram após soltarem as amarras do padrão-ouro.

Com a crise se agravando na Alemanha, Woytinsky continuava a campanha pelo programa de obras públicas e buscou o apoio de Fritz Baade, economista do SPD e membro do Reichstag, e Fritz Tarnow, presidente do Sindicato dos Madeireiros, para a elaboração de um plano prático, que ficou conhecido como Plano WTB, as iniciais dos três formuladores. Nas eleições de 1932, os nazistas haviam conquistado 230 das 568 cadeiras do Reichstag e a maioria parlamentar era formada por nazistas e comunistas, correntes pouco simpáticas à autoridade da República de Weimar. Foi nesse espírito que o SPD se reuniu para discutir o plano WTB, em 1932. Mais uma vez, não se chegou a um consenso. Woytinsky reproduz da seguinte forma a posição de Hilferding:

"Colm e Woytinsky", [Hilferding] disse, "estão questionando os fundamentos de nosso

${ }^{353}$ WOYTINSKY, 1961, pp. 467-468. 
programa [do SPD], a teoria de Marx do valor-trabalho. Nosso programa se baseia na convicção de que o trabalho, e só o trabalho, cria valor. Os preços se desviam do valortrabalho sob o impacto da interação de oferta e demanda. Depressões resultam da anarquia do sistema capitalista. Ou elas chegam a um fim, ou têm de levar ao colapso do sistema. Se Colm e Woytinsky pensam que podem mitigar uma depressão com obras públicas, estão apenas mostrando que não são marxistas.",354

Trata-se da fala de Woytinsky relatando Hilferding, mas, dentro do raciocínio marxista daquele momento, de fato não parecia haver possibilidade de conceber um programa de obras públicas. A depressão era vista como sintoma da derrocada do sistema. Como se sabe, o plano WTB não foi adotado e, ao longo dos anos 1930, a esquerda alemã tendeu a perder poder político, com a ascensão do regime autoritário nazista. O que vale reter desse relato da atuação de Woytinsky no meio político-partidário alemão é a presença, nesse contexto do período entreguerras, de um embate de ideias econômicas: novas propostas eram elaboradas, com base na ideia de estímulo à demanda, mas esbarravam em concepções já estabelecidas, por vezes institucionalmente arraigadas.

Woytinsky foi um autor que abordou questões afins e propôs soluções similares às discutidas por Simonsen: a recuperação da economia europeia deveria passar pela racionalização da produção e pelo estímulo à demanda, por meio de altos salários. Retornando à questão da teoria do comércio internacional, convém lembrar que Simonsen citou Woytinsky, provavelmente via Manoilescu, para fornecer dados estatísticos que ajudassem a dar sustentação à teoria protecionista do comércio internacional - esta teoria não era de Woytinsky, mas, sim, de Manoilescu, e Simonsen apropriou-se dela, de forma consciente e articulada, para fazer a sua defesa do protecionismo industrial no Brasil. O recurso aos dados compilados por Woytinsky, em si, já demonstra uma preocupação importante, quando se tem em conta a difusão internacional das ideias como dimensão da formação de um pensamento econômico nacional: Simonsen deu algum tipo de evidência numérica - ou empírica - daquilo que estava propugnando. Além do mais, não se trata de estatísticas quaisquer, mas, sim, de uma compilação feita por um autor que, como vimos, era preocupado com as questões relativas à recuperação de economias enfraquecidas e ao desenvolvimento das mesmas. Nesse sentido, há influência teórica clara de Manoilescu em Simonsen e, com Woytinsky, há uma sintonia que ajuda a reconstituir o ambiente de ideias em que transitou Simonsen no início dos $\operatorname{anos} 1930$.

\footnotetext{
${ }^{354}$ WOYTINSKY, 1961, p. 471. Gehrard Colm era um reputado acadêmico, que foi escolhido por Woytinsky para ser o portavoz do ADGB - e do plano WTB - na reunião com os representantes do Partido Social-Democrata.
} 


\subsubsection{O Tratado Comercial de 1935 e a participação de Simonsen}

A conjuntura internacional, na primeira metade da década de 1930, foi marcada pela turbulência da crise e da Grande Depressão. Verificou-se forte contração da liquidez no mercado mundial e uma notável diminuição dos fluxos comerciais e financeiros. A crise também revelou alterações no próprio arcabouço da economia mundial. Países antes dominantes, como a Inglaterra, experimentavam um declínio relativo, enquanto outros, como a Alemanha, que se recuperava de uma grave crise no pós-guerra, começavam a despontar como importantes atores do comércio internacional. ${ }^{355}$

A Alemanha, em particular, passou a disputar mercados, antes pouco atingidos por suas exportações, buscando a obtenção de acordos bilaterais de comércio compensado. O comércio de compensação se caracterizava pela supressão da utilização de divisas nas relações comerciais. Criava-se em ambos os países envolvidos "caixas de compensação". No caso alemão, o comércio era feito por meio dos Aski-mark ou marcos bloqueados, dotados de inconversibilidade. ${ }^{356}$ Nesse sistema, a importação alemã seria paga em Aski-mark, que só poderiam ser usados para adquirir outros produtos alemães, ou seja, toda importação daria origem, automaticamente, a uma exportação de igual valor, de modo a deixar a balança comercial equilibrada. As compensações não se faziam no cômputo geral, mas, sim, país a país, o que não era factível na prática, de forma que, se um país tivesse marcos inconversíveis e não pretendesse despendê-los todos em produtos alemães, tinha de vendê-los, com deságio, a clientes de produtos de origem germânica. Como se pode perceber é uma modalidade de comércio que tende a vincular os parceiros em trocas bilaterais.

Esta política foi contraposta veementemente pelos esforços da política externa dos EUA, os quais, nesse contexto, procuraram obter a assinatura de acordos com o Brasil e vários outros países, pautados na cláusula de nação mais favorecida, a fim de assegurar sua predominância econômica e política nesses mercados, considerados estratégicos. Esse tipo de cláusula é comum aos tratados comerciais de cunho liberalizante e estabelece que cada país signatário deve dispensar ao outro tratamento não menos favorável do que aquele reservado aos produtos de qualquer outro país com que mantenha relações comerciais, independentemente de ter ou vir a ter outros tratados vigentes com outra nação.

\footnotetext{
355 ABREU, Marcelo de Paiva. “Crise, crescimento e modernização autoritária: 1930-1945”. IN: (org.). A ordem do progresso. Rio de Janeiro: Campus, 1990. p. 73. Para análises mais abrangentes da política externa brasileira no período ver: ABREU, Marcelo de Paiva. O Brasil e a economia mundial, 1930-1945: políticas econômicas externas e relações econômicas internacionais. Rio de Janeiro: Civilização Brasileira, 1999; HILTON, Stanley. O Brasil e as Grandes Potências: os aspectos políticos da rivalidade comercial, 1930-1939. Rio de Janeiro: Civilização Brasileira, 1977; MOURA, Gerson. Autonomia na Dependência: A política externa brasileira de 1930-1942. Rio de Janeiro: Nova Fronteira, 1980.

356 SEITENFUS, Ricardo. O Brasil vai à guerra. 3. ed. Barueri: Manole, 2003. pp. 18-19. A sigla Aski significa Ausländer Sonderkonto für Inlandszahlungen (conta especial para estrangeiros, para pagamentos internos).
} 
A primeira metade dos anos 1930 foi, para além desse quadro mais geral, um momento crítico para a economia brasileira. A crise econômica mundial coincidiu ainda com uma crise da economia cafeeira, patente desde a década anterior. $\mathrm{O}$ choque externo sobre a economia brasileira afetou o balanço de pagamentos, principalmente por meio de forte queda dos preços de exportação, não compensada por aumento do quantum exportado, e por meio da interrupção do influxo de capitais estrangeiros. ${ }^{357}$ Houve declínio da renda nacional, que teria sido mais drástico não fossem os efeitos anticíclicos das políticas de defesa do setor cafeeiro e pelo desempenho favorável da emergente indústria nacional. ${ }^{358}$

Esse desarranjo econômico ocorreu em paralelo com mudanças políticas importantes, que não se restringiram ao Brasil, sendo antes fenômenos globais ${ }^{359}$. Aqui a Revolução de 1930 abriu novas possibilidades de mudanças ao deslocar a oligarquia cafeeira da posição hegemônica e ao constituir um arranjo político no qual nenhum setor dominante tinha condições imediatas de firmar sua proeminência. Os anos iniciais da década de 1930 foram de grande instabilidade, com diferentes projetos em luta pela condução da política econômica nacional. $^{360}$

Foi no quadro histórico esboçado acima que os Estados Unidos tomaram a iniciativa de iniciar, em 1933, as negociações para a assinatura de um tratado bilateral de comércio com o Brasil, fundamentado na cláusula de nação mais favorecida. As concessões do lado brasileiro incluíam a redução da tributação sobre uma extensa lista de produtos, entre os quais bens de consumo duráveis. Já os Estados Unidos se comprometiam a manter o café na lista de produtos isentos de tributação, além de conceder reduções tarifárias para alguns artigos, em sua maioria bens primários. ${ }^{361}$

O governo brasileiro inicialmente não demonstrou grande interesse na assinatura do Tratado, mas acabou cedendo às pressões norte-americanas. O Departamento de Estado dos EUA utilizou ameaças de imposição de controle unilateral do intercâmbio com o Brasil e de taxação sobre o café para extrair as concessões pretendidas. ${ }^{362} \mathrm{O}$ acordo foi negociado em sigilo, pelo representante plenipotenciário do Brasil em Washington, o embaixador Oswaldo

\footnotetext{
${ }^{357}$ ABREU, 1990, p. 74.

${ }^{358}$ FURTADO, Celso. Formação Econômica do Brasil. 34. ed. São Paulo: Companhia das Letras, 2007. caps. XXXI e XXXII, pp. 263-285.

${ }^{359}$ Houve no período mudanças de regime em vários países, tais como a ascensão do fascismo na Europa e de regimes autoritários na América Latina. Para uma análise do quadro político e econômico geral do período do "entre guerras", ver HOBSBAWM, Eric. A Era dos Extremos: O breve século XX (1914-1991). São Paulo: Cia. das Letras, 1995. p. $90-143$.

${ }^{360}$ CORSI, Francisco Luis. "Brasil e Argentina: uma análise das políticas econômicas do período 1930-1945”. In: Revista de Economia Política e História Econômica, n. 5, julho de 2006. p. 46-47.

${ }^{361}$ Presidência da República. Decreto N. 542, de 24 de dezembro de 1935, que promulga o Tratado de Comércio entre os Estados Unidos do Brasil e os Estados Unidos da América, contém sua redação integral, além de um apêndice que traz as listas de produtos contemplados e suas respectivas tarifas.

${ }^{362}$ ABREU, 1990, p. 74.
} 
Aranha, e o secretário de Estado norte-americano Cordel Hull, sendo assinado em 2 de fevereiro de 1935 .

De acordo com a Constituição de 1934, então vigente, uma vez assinado, o Tratado teria que ser ratificado pelo Congresso Nacional para entrar em vigor. Sob pressão do Departamento de Estado dos EUA para que fosse rapidamente aprovado, o Acordo teve de ser revelado publicamente. $\mathrm{O}$ encaminhamento parlamentar para a ratificação acabou por suscitar um amplo e acalorado debate público, na imprensa, na Câmara dos Deputados, nas associações de classe e até no seio do Estado e seus órgãos.

O debate em questão contrapôs os defensores da liberalização do comércio e os defensores de políticas de caráter protecionista e assistiu à articulação de grupos de interesse, que se posicionaram em função de objetivos de classe, ou de outra ordem, definidos com maior clareza no decurso do próprio debate. Propiciou também a formulação e apresentação pública de projetos nacionais divergentes e antagônicos. Após longo impasse, foi necessária a atuação direta do próprio Getúlio Vargas para que a ratificação do Tratado fosse efetivada, em 24 de dezembro de 1935.

A historiografia que lida com o Tratado de 1935 inclui alguns estudos que veem o Tratado como expressão de interesses contrários à indústria brasileira. Dentro dessa linha interpretativa, algumas ideias gerais se destacam. A primeira é que o Tratado teria sido claramente contrário aos interesses da indústria nacional. Em segundo lugar, o acordo teria sido uma oportunidade para que os industriais se articulassem em torno da defesa de seus próprios interesses, diante dos interesses da lavoura ou do café, que prevaleceriam com a ratificação. ${ }^{363}$

Essas ideias são qualificadas pelo trabalho de Pedro Dutra Fonseca, que vê no Tratado uma política de cunho industrializante, por ter supostamente facilitado a importação de máquinas para o Brasil. ${ }^{364} \mathrm{O}$ estudo de Danilo Lima corrobora com a ideia de que o Tratado foi lesivo aos interesses dos industriais brasileiros, mas questiona a oposição entre interesses industriais e da lavoura. Nessa perspectiva, a suposta oposição entre indústria e os "interesses da agroexportação", encontrada na historiografia para caracterizar e explicar o episódio, não se sustenta, ao menos dessa maneira simplificada. A defesa do Tratado, no debate parlamentar, praticamente não teria contado com as participações de indivíduos identificados

\footnotetext{
${ }^{363}$ Ver os seguintes trabalhos: D’ARAÚJO, Maria Celina; MOURA, Gerson. “O tratado comercial Brasil-EUA de 1935 e os interesses industriais brasileiros.” Revista de Ciência Política, Rio de Janeiro, v. 21, n. 1, p. 55-73, jan./mar. 1978; LEOPOLDI, 2000, p. 93-152; LEME, 1976, p. 296.

${ }^{364}$ Ver FONSECA, 2003. Já nos referimos a este texto quando se discutiu a política econômica de Vargas, nos inícios da década de 1930. A ideia de que o Tratado refletia uma política de cunho industrializante parece não corresponder àquilo que sobressai das listas de isenção presentes no texto do Decreto N. 542 de 1935: reduziam-se as tarifas incidentes sobre um longo rol de produtos industrializados norte-americanos, ao passo que se mantinham o café e alguns produtos primários livres de tarifação.
} 
como representantes de frações de classe ligadas a atividades de agroexportação: ao contrário, tal defesa teria ficado a cargo de membros da burocracia estatal. Uma hipótese para explicar essa ausência de uma defesa parlamentar mais aguerrida do Acordo, por parte do setor agrário, é que não seria preciso se posicionar de forma tão enfática nesse momento. Os setores ligados à agroexportação não precisavam reafirmar seus interesses com a mesma eloquência da burguesia industrial, porque o Tratado, em tese, lhes seria benéfico, ao fomentar as exportações brasileiras de produtos primários. ${ }^{365}$

Para os propósitos deste trabalho, convém reter dessa discussão a ideia de que o Tratado Comercial de 1935 colocou em discussão o tipo de inserção internacional do Brasil, num momento em que o alinhamento político e econômico com os Estados Unidos, que se firmaria nos anos 1940, já com a guerra em andamento e a vitória aliada relativamente clara, ainda não era algo certo. Nesse contexto, a posição dos industriais, ao menos no debate parlamentar, ocorrido na Câmara dos Deputados, era clara e contrária ao Tratado. Como porta-voz dos industriais paulistas e deputado classista eleito à Câmara Federal, Simonsen defendeu essa posição, mas não se restringiu a isso: ao recorrer a excursos históricos e a outros autores para embasar seu discurso, Simonsen construiu uma argumentação que, como veremos, tem elementos de um pensamento econômico próprio. Não se trata de um pensamento filiado a uma corrente teórica específica, mas, sim, uma elaboração que recorria a referências múltiplas, para sustentar uma causa ligada a interesses de classe.

O discurso de Simonsen por ocasião dos debates em torno do Tratado Comercial, pronunciado na Câmara dos Deputados em 11 de setembro de 1935, foi uma peça de defesa do protecionismo: Simonsen era claramente contra a cláusula de nação mais favorecida, estabelecida no Tratado, em favor dos EUA. Identifica-se como "apartidário" e defensor dos interesses ligados à produção nacional, já que fora escolhido como candidato independente dos sindicatos industriais paulistas. $\mathrm{O}$ fio condutor do discurso era que o livre-cambismo não é uma política adequada ao Brasil, que deveria adotar, em seu lugar, o protecionismo.

\footnotetext{
Mas a experiencia de mais de um século, está ahi, a demonstrar que, si o liberalismo politico determina a igualdade dos direitos politicos de todos os indivíduos dentro de uma mesma patria e o respeito inviolavel dos direitos politicos da propria Nação, a idéa livre cambista significa a predominancia dos mais fortes e dos melhores organizados em materia economica, o que vale dizer, falando sem peias, que pode arrastar os individuos e os paizes até quasi a servidão economica. ${ }^{366}$
}

\footnotetext{
${ }^{365}$ LIMA, Danilo Barolo Martins de. A hegemonia como processo: elite burocrática, ideias econômicas e a conformação de grupos de interesse sobre o Tratado de Comércio Brasil-EUA (1935). IN: VI Encontro Nacional de Pós-Graduação em História Econômica/ABPHE. São Paulo: ABPHE, 2012.

${ }^{366}$ Anais da Câmara dos Deputados, v. XVI (11/09/1935). p. 268. O discurso proferido por Simonsen na Câmara também foi publicado em brochura, em português e em inglês. Ver SIMONSEN, Roberto. Aspectos da política econômica nacional. São Paulo: Empresa Graphica da "Revista dos Tribunaes", 1935. Para a tradução inglesa, ver Aspects of National Political Economy. São Paulo: sem editora, 1935.
} 
Em assuntos econômicos, dizia-se adepto da "escola realista": "procuro, na ancia da comprehensão estudar sempre as ligações entre os conceitos scientificos, expostos pelos doutos, e o meio real em que vivemos" ${ }^{\text {367 }}$. A estratégia discursiva de Simonsen era buscar, na história, bases para seu argumento de que o livre-cambismo servia aos países mais ricos, sendo prejudicial àqueles que estão se desenvolvendo. Afirmava que, embora tivesse escrito belas páginas, Adam Smith não conseguiu prever, como os demais cultores do liberalismo clássico, a forma que tomaria "a economia do livre câmbio" na era dos grandes meios de transporte, dos processos de fabricação em série e dos métodos modernos de racionalização e de negócios.

Simonsen mencionou em seu discurso parlamentar teóricos, como Karl Rodbertus, que teria voltado à concepção smithiana de que a divisão do trabalho constitui a base da “expansão comercial”, colocando-a em seus devidos termos, isto é, procurando ressaltar o aspecto social da divisão do trabalho. Para tratar disso, Rodbertus teria destacado o fundamento orgânico dos Estados, seu processo de formação histórica e seu papel preponderante no fortalecimento dos direitos sociais. Na linha da crítica à concepção livrecambista, Simonsen citou Friedrich List e seus seguidores que teriam feito "apparecer, nas relações da economia politica a existencia de nações, individualidades distinctas, provenientes de um processo determinado de formação histórica". O livre-cambismo não contribuiria para o fortalecimento da "economia nacional", conceito cujo estabelecimento Simonsen creditava a Adolph Wagner, em seu livro Fundamentos de Economia Política (Grundlegungen der politischen Ökonomie, no original).

Esses três autores alemães compõem um quadro de influências bastante diverso, que pode dar uma ideia dos caminhos pelos quais Simonsen transitou ao buscar subsídios para fundamentar sua argumentação parlamentar em oposição ao Tratado de Comércio. A influência do Sistema Nacional de Economia Política de Friedrich List sobre o pensamento de Simonsen e de outros industrialistas brasileiros já é bastante conhecida e já foi comentada acima. Nesta parte do trabalho, dá-se ênfase às influências, no pensamento de Simonsen, dos dois outros autores citados por ele no discurso contra o Tratado de 1935: Karl Rodbertus e Alfred Wagner.

\section{Rodbertus e Wagner}

O nome de Johann Karl Rodbertus (1805-1875) está ligado à defesa de um "socialismo de Estado", embora fosse um monarquista conservador e recusasse a abolição imediata da

\footnotetext{
${ }^{367}$ Anais da Câmara dos Deputados, v. XVI (11/09/1935) pp. 265-266.
} 
propriedade privada. Suas principais contribuições estariam relacionadas à teoria da renda da terra e à sua ideia de pobreza e de ciclos econômicos. Sua principal recomendação de política econômica era que se eliminassem a pobreza e os ciclos - as crises de subconsumo - por meio da redistribuição de renda e da regulação de preços, por parte do Estado. ${ }^{368}$ Inicialmente um magistrado, Rodbertus se estabeleceu numa fazenda na região da Pomerânia, onde se dedicou aos estudos econômicos e aos negócios locais. Entre 1848 e 1849, participou ativamente da política de seu país: foi deputado ao parlamento prussiano e, durante um mês, ministro do Culto e Instrução Pública. Defensor convicto da unidade alemã, teve longa correspondência com o líder social-democrata alemão Ferdinand Lassalle. ${ }^{369}$

Schumpeter arrola três obras que considera as mais relevantes de Rodbertus: Zur Erklärung unserer staatswirtschaftlicher Zustände ("Explicação das nossas situações econômico-estatais", 1842), Sociale Briefe an von Kirchmann ("Cartas sociais a von Kirchmann", 1850-51, traduzido para o inglês em 1898 sob o título Overproduction and crises) e Zur Erklärung und Abhülfe der heutigen Creditnoth des Grundbesitzes ("Para explicação e solução do atual problema de crédito da propriedade fundiária”, 1868-69). Desses escritos, o que mais interessa aqui são as cartas a von Kirchmann, por ser provavelmente a obra a que Simonsen teve acesso. Além da tradução inglesa mencionada por Schumpeter, a quarta carta a von Kirchmann foi editada e publicada em 1899, em Berlim, por Adolph Wagner e Teophil Kozak, sob o título de Das Kapital (“O capital”). Esta quarta carta, que versa sobre a teoria da renda da terra, das crises e do capital, foi traduzida para o francês e publicada em 1904. ${ }^{370}$ Tal tradução chegou ao Brasil, como atesta a presença de um exemplar na biblioteca da Faculdade de Direito da USP. ${ }^{371}$

Um dos pontos importantes do conteúdo desta carta-livro é a teoria das "crises comerciais" (Handelskrisen), esboçada por Rodbertus em sua contestação a Kirchmann. Como veremos, trata-se de uma elaboração teórica de cunho antiliberal, que coloca ênfase na questão salarial, desembocando numa solução redistributiva. Kirchmann via as crises de subconsumo - situações em que a população sofre de carência, convivendo com a acumulação de estoques, por parte dos capitalistas - como uma consequência dos baixos salários pagos pelos capitalistas, que não dividem o produto do trabalho de forma igualitária, abocanhando-o

\footnotetext{
${ }^{368}$ SCHUMPETER, Joseph A. História da análise econômica. [1954]. v. 2. São Paulo/Lisboa: Fundo de Cultura, 1964. p. 155. Ver, também, SCREPANTI e ZAMAGNI, 2005, p. 139.

${ }^{369}$ BURDEAU, François. "Rodbertus, Johann Karl (1805-1875)". IN: Enciclopaedia Universalis. (digital). Consultado em: 18 de março de 2013.

${ }^{370}$ RODBERTUS, Johann Karl. "Das Kapital. Vierter sozialer Brief an von Kirchmann” [1854]. IN: Gesammelte Werke und Briefe. Abteilung I, Band 2. Osnabrück: Otto Zeller, 1971. Compilação fac-similar a partir de edições anteriores, com introdução e bibliografia de Theodor Ramm.

${ }^{371}$ RODBERTUS, Johann Karl. Le capital. Paris: V. Giard \& E. Brière, 1904.
} 
sob a forma de "ganho do capital" (Kapitalzins). ${ }^{372}$ Rodbertus contesta essa ideia, atribuindo a causa das crises a uma disfunção intrínseca à economia de mercado capitalista.

Nossas crises comerciais, em uma palavra, não são culpa de uma classe da
sociedade, porém um problema intrínseco, imutável, de uma circulação deixada a
sua própria sorte. As crises são os paroxismos do defeito que se sobressai na
organização econômica atual: a produtividade pode crescer a uma proporção
qualquer, ao passo que se reduzem as partes do produto nacional que constituem os
salários. ${ }^{373}$

A explicação para as crises deriva, para Rodbertus, do fato de que a participação relativa dos salários na renda nacional decresce, ao longo do desenvolvimento capitalista. Isso geraria uma incapacidade, por parte das massas trabalhadoras, de adquirir o produto de seu trabalho, o que resultaria numa situação de superprodução e subconsumo, na medida em que se acumulariam estoques invendáveis. O argumento não é exatamente protecionista, mas é certamente antiliberal.

Nas condições de hoje, isto é, dada a expansão do princípio do livre mercado para a taxa de salário e dada uma produtividade crescente, as participações relativas na renda se mantêm? Dada esta organização - ou desorganização - a parte que cabe à maior parte da sociedade, à classe trabalhadora, não diminui à proporção que cresce a produtividade? ${ }^{374}$

O fato de que a produtividade cresce ao passo que se reduz a participação relativa dos salários na renda é atribuído à "expansão do princípio do livre mercado" para a negociação salarial, isto é, havendo um mercado desregulado, os capitalistas pagariam os salários mais baixos possíveis: os salários tenderiam à subsistência. A solução para esse problema passaria por medidas de cunho redistributivo, que fizessem a participação relativa do salário acompanhar a produtividade, que é crescente. O Estado teria papel importante nessa redistribuição. ${ }^{375}$ Simonsen atribuía a Rodbertus uma revisão importante da economia smithiana, dando ênfase à importância do Estado:

Rodbertus, voltando ao estudo da divisão do trabalho, que pela theoria dos classicos, constitue a base da expansão comercial, colloca essa magnifica concepção de Adam Smith em seus devidos termos, procurando resaltar o seu aspecto social, o fundamento organico dos Estados, o seu processo de formação historica e o preponderante papel que lhe estava reservado no exercicio dos direitos sociaes. ${ }^{376}$

É importante frisar que Simonsen fazia uma apropriação seletiva de Rodbertus: se reconhecia o papel "preponderante" do Estado no "exercício dos direitos sociais", Simonsen não corroborava a ideia de que a redistribuição das rendas deveria ser uma prioridade da

\footnotetext{
${ }^{372}$ RODBERTUS, 1971 [1854], pp. 38-39.

${ }^{373}$ RODBERTUS, [1854] 1971, p. 63.

${ }^{374}$ RODBERTUS, [1854] 1971, p. 58.

${ }^{375}$ Schumpeter é crítico da teoria das crises de Rodbertus, por acreditar que a ideia de que a participação relativa dos salários na renda declina com o desenvolvimento capitalista não se sustenta empiricamente. Ver SCHUMPETER, [1954] 1964, v. 2, p. 156.

${ }^{376}$ Anais da Câmara dos Deputados, v. XVI(11/09/1935), pp. 266-267.
} 
política econômica estatal. Pelo contrário, tendia a ver a deficiência do quantum de riqueza produzida como o grande problema da economia brasileira. Em discurso proferido alguns anos depois, no Instituto de Engenharia de São Paulo, Simonsen deixaria clara sua posição com relação a esse tema: "Sem negar, por exemplo, a necessidade de uma conveniente legislação social, não podemos esconder que, entre nós, o problema da criação de riquezas é tanto ou mais importante que o da sua redistribuição". 377

Segundo Schumpeter, a obra de Rodbertus foi trazida ao primeiro plano do debate econômico alemão nas duas últimas décadas do século XIX devido à releitura e defesa feitas por Adolph Wagner, o outro autor alemão citado por Simonsen em seu discurso. De fato, como mostra a compilação fac-similar feita em 1971, algumas das obras de Rodbertus foram reeditadas, no final do século XIX, por Adolph Wagner. ${ }^{378}$ Em seus Fundamentos, que abordaremos a seguir, Wagner citou Rodbertus diversas vezes e, na parte do livro referente ao conceito de economia nacional, as citações eram elogiosas. Wagner entrou no discurso de Simonsen como aquele que teria melhor definido o conceito de economia nacional: "Foi Adolph Wagner, em seus 'Fundamentos de Economia Política', quem primeiro e melhor estabeleceu o conceito da economia nacional, de capital nacional e da renda nacional". 379

Adolph Wagner (1835-1917) foi um economista alemão integrante do movimento que ficou conhecido como "socialismo de cátedra" (Kathedersozialismus), composto, segundo Schumpeter, por políticos e leigos progressistas, que pregavam a reforma e denunciavam os interesses que lhes eram obstrutivos. ${ }^{380}$ Wagner foi, assim como Gustav von Schmoller, membro do Verein für Sozialpolitik ("Sociedade para a Política Social”), grupo que reunia os principais economistas do período bismarckiano na Alemanha. ${ }^{381}$ Embora fossem membros da mesma associação, a relação de Wagner com a escola histórica, liderada por Schmoller, não era das mais amistosas. Wagner se identificava como mais teórico do que seus colegas adeptos do método historicista. Schumpeter destaca a teoria monetária e as finanças públicas como as áreas em que Alfred Wagner se teria destacado como economista. Sua obra de relevo

\footnotetext{
377 SIMONSEN, Roberto. “Objetivos da Engenharia Nacional”. [1939]. IN: A engenharia e a indústria. São Paulo: FIESP, 1945. Esta coletânea, publicada em 1945, foi uma reedição de trabalhos enviada por Simonsen ao II Congresso Brasileiro de Engenharia.

378 Trata-se da referida obra "Das Kapital" e de "Sendschreiben an den Arbeiterkongress während der Londonder Industrieausstellung" ("Missiva ao Congresso de Trabalhadores durante a Exposição Industrial de Londres"), publicado em 1862 por Rodbertus e reeditado em 1899 por Wagner. Ver a compilação de obras Gesammelte Werke und Briefe, de 1971.

${ }^{379}$ Anais da Câmara dos Deputados, v. XVI (11/09/1935), p. 267.

${ }^{380}$ SCHUMPETER, [1954] 1964, vol. 3, p. 70.

${ }^{381}$ O conhecimento produzido pelo Verein circulou numa série de 188 publicações: as Schriften des Vereins für Sozialpolitik [Escritos da Sociedade de Política Social]. Ver SCHUMPETER, [1954] 1964, vol. 3, pp. 78-79. A Sociedade, fundada em 1873, existe até hoje (após uma interrupção entre 1936 e 1956) e surgiu num momento em que a Alemanha se tornava, sob liderança prussiana, uma grande potência industrial: seus membros, em sua maioria, eram contrários ao "liberalismo de Manchester", como era chamada a escola inglesa, e também viam com maus olhos as posições assumidas por Marx ou Lassalle. Entre seus membros estiveram Max Weber e Werner Sombart, num momento posterior.
} 
foram os Fundamentos (Grundlegung der politischen Oekonomie), cuja primeira edição data de 1876.

Os indícios apontam que, embora não tenha feito citação textual em seu discurso (mencionou apenas o nome de Wagner e o conceito de economia nacional), Simonsen teria retirado desta obra principal a ideia de economia nacional, citada na arenga contra o Tratado Comercial com os Estados Unidos. O livro recebeu uma tradução francesa, em 1909, e exemplares desta obra se encontram nas bibliotecas da Faculdade de Economia, Administração e Contabilidade e da Faculdade de Direito, ambas da Universidade de São Paulo. O fato de a edição de 1909 ter circulado no Brasil em francês, como, de resto, as obras de diversos autores estrangeiros citados por Simonsen, aponta para a possibilidade de Simonsen ter tido algum contato com ela. Vale dizer que tanto o livro analisado de Wagner quanto o de Rodbertus ( $O$ capital) tiveram suas edições francesas feitas pela editora V. Giard \& E. Brière, que teve papel importante na divulgação de livros estrangeiros no Brasil, no início do século XX. ${ }^{382}$

Do ponto de vista do conteúdo, os indícios são contundentes. O livro III da referida obra é dedicado ao tema: "Economia e economia nacional". As definições apresentadas por Wagner podem ajudar esclarecer o que Simonsen queria dizer com "economia nacional" no texto de 1935.

[A economia nacional é] o conjunto, considerado como um todo fechado, das economias individuais independentes unidas pela articulação do trabalho e relacionadas entre si, segundo uma regulação determinada pelo direito econômico (regulação do direito econômico e administrativo), no seio de um povo organizado em Estado (ou em confederação) ou em algum tipo de domínio econômico resultante de regras econômicas estatais ("Zollverein"): trata-se de uma combinação orgânica e não somente uma justaposição mecânica de economias individuais. ${ }^{383}$

Em seguida à definição de economia nacional, Wagner esboçou uma tipologia do desenvolvimento dessas economias nacionais. A formação de uma economia nacional se daria após a comunidade humana ter passado por fases sucessivas: raça, gente (gens, em francês), tribo e, por fim, nação (Volk, em alemão na edição francesa). Nas fases iniciais, a economia nacional estaria em forma embrionária: só começa a existir de fato quando as "as relações de sociedade são substituídas por relações econômicas", o que caracterizaria o momento final dessa sequência - a fase "nação".384

Esse processo envolveria um afrouxamento dos laços estreitos de sangue das comunidades humanas e a superação das relações de autoridade e das maneiras de ver o

\footnotetext{
${ }^{382}$ Ver PERICÁS, Luiz Bernardo. “José Carlos Mariátegui o Brasil'. IN: Estudos avançados. (digital). vol. 24, n. 68, 2010. pp. 335-361.

${ }^{383}$ WAGNER, Adolph. Les fondements de l'économie politique. [1876]. t. II. Paris: V. Giard \& E. Brière, 1909. pp. 14-15. ("Economia nacional - Noção e essência").

${ }^{384}$ WAGNER, [1876] 1909, p. 20.
} 
mundo baseadas nos sentimentos pessoais e no costume. Em lugar desses determinantes ligados às relações pessoais e às tradições dos grupos humanos, passariam a prevalecer, numa economia nacional, a troca, a divisão do trabalho e os contratos. ${ }^{385}$ Quatro fatores fundamentais seriam determinantes do desenvolvimento das economias nacionais: o fator nacional em si, o geográfico, o econômico-técnico e o político-jurídico. A partir desses quatro aspectos, haveria como distinguir os tipos comuns, os "traços concordantes fundamentais" que poderiam ser encontrados em cada um dos períodos históricos atravessados por economias nacionais rumo à civilização. Seria possível definir, então, "fases típicas" da economia nacional em geral, formando um fenômeno coletivo geral da história humana. ${ }^{386}$

Wagner estende sua tipologia da economia nacional para a economia mundial ou universal - e a compreende como "um grande organismo, no qual as diferentes economias nacionais (...) desempenham a função de membros." ${ }^{387}$ São duas ordens de fatores a impulsionar o desenvolvimento da economia universal: os relacionados à possibilidade e os ligados à causalidade. Os primeiros fatores seriam a segurança jurídica (estado das artes do direito internacional, mecanismos de proteção aos interesses nacionais no estrangeiro) e o estado dos meios de comunicação e transportes. Os fatores relacionados com a causalidade seriam: as diferentes constituições naturais dos países e dos povos e a diferença do grau de desenvolvimento das economias nacionais particulares. A divisão nacional do trabalho dá lugar, no âmbito da economia mundial, à divisão internacional do trabalho. ${ }^{388}$

Wagner reconhecia que, em virtude das diferenças na constituição natural dos países, havia uma conformidade da divisão internacional do trabalho à natureza e que, a partir disso, podiam-se tirar justificativas favoráveis ao sistema de livre-comércio. Mencionou que Friedrich List, admitira, em seu Sistema Nacional, as vantagens do intercâmbio de mercadorias entre a zona temperada e os trópicos. Salientava, no entanto, que a tese da necessidade natural do comércio exterior era, por vezes, levada muito longe: a expansão, pela civilização humana, das "plantas úteis" (cereais, hortaliças, etc.) e animais domésticos por várias nações localizadas em áreas geográficas distintas ao redor do globo seria uma prova de que não são somente os fatores naturais que determinam, de forma absoluta, o tipo de atividade que se realiza nos diversos países. No caso das plantas, por exemplo, diversos países poderiam produzir os mesmos gêneros, não sendo estritamente necessário praticar o comércio: parte da produção adquirida ao exterior poderia ser internalizada. ${ }^{389}$

\footnotetext{
${ }^{385}$ WAGNER, [1876] 1909, p. 20.

${ }^{386}$ WAGNER, [1876] 1909, pp. 20-21.

${ }^{387}$ WAGNER, [1876] 1909, Grifos do autor.

${ }^{388}$ WAGNER, [1876] 1909, pp. 28-29.

${ }^{389}$ WAGNER, [1876] 1909, pp. 33-34.
} 
Outro nicho do mercado internacional em que os fatores climáticos seriam relativizados é o da troca de produtos minerais de um país contra os produtos agrícolas e industriais dos outros. A circulação dos derivados de carbono e metais (minerais) não dependeria somente da distribuição física de tais produtos, mas do domínio da técnica de extração, da legislação e de sua aplicação. Nesse sentido, a circulação de minerais estaria muito mais sujeita ao movimento e às mudanças históricas, refletidas no apuro da técnica, do que a circulação de bens resultantes do "monopólio climatérico", isto é, os que dependem de um tipo específico de clima para serem produzidos. ${ }^{390}$

Ganha importância, nesse ponto, o segundo fator causal determinante do desenvolvimento da economia mundial: o grau diferente de desenvolvimento das nações. Essa diferença no nível de desenvolvimento - nações diferentes poderiam estar em distintas "fases típicas" de evolução econômica - estaria assentada em bases naturais, mais ou menos sólidas, e no caráter quase invariável das populações (marcado por questões raciais): disso resultaria uma circulação internacional "natural" que, a prevalecerem os fatores de ordem física, tenderia a permanecer imutável. Todavia, essa circulação natural estaria sujeita a grandes mudanças históricas, pois nem sempre prevaleceriam apenas os fatores físicos. O argumento é que o desenvolvimento de uma economia nacional externa poderia significar uma limitação da circulação econômica em cada âmbito interno e acarretar uma regressão na economia mundial como um todo, regressão que por vezes escapa à vista, devido a melhorias nos meios de comunicação, por exemplo, que elevam a grandeza absoluta do comércio internacional. Como exemplos, Wagner citou a América do Norte após a Guerra Civil e o continente europeu após o retorno à política protecionista (impostos de proteção agrícola) na última metade da atual geração (1876). ${ }^{391}$

Tratava-se de relativizar a ideia de que a diferença de graus de desenvolvimento seria sempre um motor no sentido do crescimento da economia universal, pela via do incremento do comércio internacional. Se, como ocorreu nos exemplos mencionados, a diferença de graus de desenvolvimento entre nações acarretasse a imposição de medidas protecionistas e controles, haveria simplesmente uma regressão econômica, ainda que meios de transporte mais sofisticados dessem a impressão de que havia um volume maior de comércio internacional e que isso significava um crescimento da economia mundial.

A teoria radical do livre-comércio não considera suficientemente, na sua defesa da justiça absoluta da política livre-cambista para todos os países e em todo tempo, o

\footnotetext{
${ }^{390}$ WAGNER, [1876] 1909, pp. 35-36.

${ }^{391}$ WAGNER, [1876] 1909, p. 37.
} 
caráter puramente relativo, para a economia universal, dessa justificativa que se fundamenta no grau diferente de desenvolvimento das economias nacionais, ${ }^{392}$

Um fato importante, apresentado por Wagner, e que relativizava a ideia de que a existência de uma economia mundial integrada comercialmente se justifica pelo grau diferente de desenvolvimento entre as nações, é a existência de economias interiores continentais. Nesse sentido, uma circulação internacional entre a Inglaterra e certas partes dos Estados Unidos cumpriria a mesma função da divisão territorial do trabalho entre Massachusetts e Iowa, por exemplo. As consequências políticas e civilizatórias integralmente positivas do comércio internacional, tão destacadas pela economia política inglesa, também mereceriam reparos: o sistema napoleônico de tratados de comércio, por exemplo, certamente tivera consequências políticas mais favoráveis à França do que ao restante da Europa.

A separação entre produtor e consumidor, a dependência de fatores políticos externos (como no caso da "cotton famine" inglesa, resultante da Guerra Civil americana), o perigo político de depender do estrangeiro para conseguir alimento, a incerteza de se conseguir transportar as mercadorias por via marítima ou passando por países estrangeiros e a substituição das indústrias tradicionais (como no caso das velhas civilizações asiáticas) por produções exportáveis - todas seriam razões para levar à reflexão sobre o tipo de efeitos que o desenvolvimento de uma economia internacional comercialmente integrada acarretava. Ademais, havendo desequilíbrios entre exportação e importação, haveria a necessidade de obter preços mais competitivos para os produtos exportados: isso poderia ter de ser feito por meio de redução salarial, o que reduziria o poder de compra das massas domésticas. ${ }^{393}$

Wagner concluía seu arrazoado sobre a economia nacional com a ideia de que se deveria distinguir entre o ponto de vista nacional e o ponto de vista cosmopolita, ao se tratar dos problemas relativos ao desenvolvimento econômico, tais como: protecionismo, livre comércio, militarismo, questões operária, agrária e industrial. As soluções para as questões colocadas seriam diferentes, dependendo do ponto de vista que se adotasse, mas o ponto de vista nacional deveria ser colocado em primeiro plano. “A economia fisiocrático-smithiana tende em demasia a uma concepção cosmopolita, já a economia mercantilista-protecionista exagera, às vezes, o ponto de vista nacional. Mas em princípio e no final das contas é esta última a mais correta."394

A conceituação de economia nacional feita por Adolph Wagner nos Fundamentos de economia política colocava ênfase na valorização do interesse nacional, quando este entrasse

\footnotetext{
392 WAGNER, [1876] 1909, p. 37.

${ }^{393}$ WAGNER, [1876] 1909, pp. 38-39.

${ }^{394}$ WAGNER, [1876] 1909, p. 39.
} 
em conflito com os interesses cosmopolitas. A teoria das crises esboçada por Rodbertus em sua carta, posteriormente intitulada $O$ capital, era baseada na ideia de que o livre mercado acabava por engendrar uma participação relativa declinante dos salários na renda, a qual, aliada a uma situação de produtividade crescente, geraria superprodução e estoques invendáveis, isto é, crises de subconsumo. Politicamente, os dois autores eram ligados ao socialismo e ao nacionalismo: Rodbertus mais próximo do primeiro e Wagner, possivelmente, mais ligado segundo. De toda forma, não eram adeptos de um socialismo radical, comprometido com transformações imediatas e amplas da sociedade: tinham uma posição mais reformista do que revolucionária.

Embora falasse de um outro lugar do espectro político - o objetivo era a defesa de interesses dos industriais paulistas - Simonsen apropriou-se dos argumentos desses autores: a importância do Estado para evitar crises e a relativização do princípio de que o livre-comércio é benéfico são certamente ideias que faziam sentido, num discurso contrário a um tratado visando à liberalização comercial. Vejamos adiante como se deu essa apropriação.

\section{As apropriações de Roberto Simonsen: organização produtiva e nacionalismo}

As afinidades de Roberto Simonsen com as ideias desses autores eram várias. No caso específico do discurso de 1935, vale ressaltar algumas razões possíveis para a inclusão desses economistas entre os nomes citados por Simonsen. No caso de Rodbertus, o elemento principal era a natureza socialmente injusta do princípio do livre mercado, sem que essa constatação implique o fim da economia de mercado capitalista, mas sua regulação. Rodbertus não atribuía à classe capitalista o problema das crises - as crises, para ele, não seriam culpa de uma classe específica - mas, sim, às disfunções do livre mercado, que permitiam que a produtividade crescesse ao passo que se reduzia a participação relativa do salário na renda. É uma ideia que reforçava o argumento, movido por Simonsen, de que o livre mercado não é sempre benéfico, pode ser benéfico para uns e prejudicial para outros: para o Brasil, país de indústria incipiente e menos produtivo do que as nações avançadas, certamente não era benéfico.

Já Adolph Wagner colocava o "ponto de vista nacional" à frente do "ponto de vista cosmopolita", quando esses dois entravam em conflito. Roberto Simonsen estava tentando mostrar que, no tratado comercial firmado com os EUA, deveriam prevalecer os interesses do Brasil, que Simonsen identifica como análogos aos interesses da indústria brasileira. Ademais, como veremos, Simonsen procurará mostrar, ao longo de sua argumentação, que diversos países desenvolvidos, inclusive os Estados Unidos, adotaram políticas protecionistas, em 
defesa dos interesses de suas indústrias nacionais, quando isso lhes foi conveniente. Wagner também formulou um esboço de tipologia do desenvolvimento, em que a fase mais "civilizada" corresponderia à nação unificada e provida dos requisitos necessários ao desenvolvimento capitalista. Essa associação entre formação da nação e progresso econômico - expresso pelo crescimento industrial - era cara a Roberto Simonsen.

A citação desses dois autores alemães vincula a argumentação de Simonsen a uma linhagem de pensamento econômico que era coerente com seus argumentos em 1935, pela crítica ao princípio do livre mercado, pela valorização dos interesses ditos nacionais e pelo reconhecimento da importância do Estado. A presença de traduções francesas dessas obras, feitas no início do século XX, em bibliotecas de São Paulo e a própria citação desses autores por Simonsen, como autoridades que dariam legitimidade ao seu discurso, apontam para a constatação de que essa linhagem de pensamento, ligada à tradição alemã, com elementos de historicismo, nacionalismo e socialismo reformista, tinha penetração no Brasil e influenciou de alguma forma as elaborações de Simonsen.

Outro ponto importante do discurso de Simonsen é a articulação entre comércio externo e capitais estrangeiros. Simonsen considerava a presença do capital forâneo no Brasil uma inevitabilidade histórica, dada a lenta formação dos capitais nacionais. Para além de presença incontornável, o capital estrangeiro teria trazido "appreciavel impulso ao progresso economico do Paiz". O problema era que tais investimentos externos acarretariam remessas cada vez maiores ao estrangeiro, que deveriam ser cobertas com os saldos de exportação. A falta de crescimento desses saldos, historicamente dependentes dos ciclos de produto único, acarretaria uma paralisação no afluxo de novos capitais.

O Brasil não era, segundo Simonsen, responsável pela dificuldade de remunerar os capitais externos: o problema advinha dos mercados internacionais, que não absorviam as exportações brasileiras. Dessa forma, a situação do capital estrangeiro no país não deveria servir como justificativa para o cerceamento da liberdade de negociar tratados de comércio. ${ }^{395}$ Em síntese: "O nosso problema resulta da impossibilidade manifesta de transferir para o estrangeiro qualquer remuneração ou rendimento, dada a feição que tomou a evolução da economia nacional, em face das economias dos demais povos."

A resolução deste problema não passaria, para Simonsen, pelo simples default dos compromissos externos: ele manifestou-se contra a suspensão do esquema Aranha, em vigor desde 1934, que previa uma retomada parcial do pagamento da dívida externa, suspenso em 1931. A solução, aventada no discurso, seria a criação de um "Instituto Nacional de

\footnotetext{
${ }^{395}$ Anais da Câmara dos Deputados, v. XVI(11/09/1935), p. 270.

${ }^{396}$ Anais da Câmara dos Deputados, v. XVI(11/09/1935), p. 272.
} 
Exportação", que deveria equacionar pagamentos aos credores internacionais, com base nos excessos de exportação, cujo cálculo se basearia no valor das exportações no decênio précrise e em índices de preços de matérias-primas. A ideia era garantir a continuidade da geração de disponibilidades para pagamento dos compromissos externos.

No fundo, a intenção era usar o capital estrangeiro como aliado do fomento econômico brasileiro, por meio de um instituto planejador - o Instituto Nacional de Exportação - que deveria trabalhar em conjunto com o Ministério da Agricultura e o Ministério do Trabalho. As importações que, no esquema, só deveriam realizar-se se houvesse, previamente, o devido numerário para pagá-las, seriam reguladas por meio de créditos do Banco do Brasil. Na ordem de preferência das importações, deveriam prevalecer: matérias-primas para a indústria, trigo, combustíveis e produtos farmacêuticos. ${ }^{397} \mathrm{O}$ incremento das exportações não deveria passar por um acordo comercial que concedesse aos Estados Unidos a cláusula de nação mais favorecida, mas, sim, pela organização interna, consubstanciada pelo Instituto Nacional de Exportação e pelos arranjos institucionais propostos, no âmbito da máquina estatal.

Agricultura e indústria eram vistos como complementares: "racionalizada a nossa produção agricola, devemos seguir, no que concerne ás industrias, uma politica abertamente proteccionista” ${ }^{\natural 98}$. A justificativa para o protecionismo é dada pela necessidade estrutural da industrialização, que se colocara ao longo da evolução histórica da economia brasileira. Já estava presente no discurso a ideia de que o ciclo da mineração tivera aspectos positivos: era descrito como aquele que "contribuiu definitivamente para a constituição da unidade do Paiz, fazendo convergir para o seu centro a atenção e os interesses que um determinismo geographico estava separando". ${ }^{399}$ O Brasil, entretanto, não soubera tirar partido dessas riquezas, tampouco o fizera a metrópole portuguesa. A riqueza das minas brasileiras teria servido para intensificar a revolução industrial inglesa. Fechado o ciclo da mineração, o Brasil se vira forçado a regressar ao ciclo puramente agrícola, "até que a cultura do café permitiu ser o que hoje somos" ${ }^{400}$. O café, entretanto, não seria suficiente.

\footnotetext{
A installação da industria no Brasil tinha que surgir como um imperativo inelutavel na historia da economia brasileira. (...) $\mathrm{O}$ cambio tinha que cahir, independentemente dos erros da politica, porque o supprimento das necessidades de um povo que se ia civilisando demandava artigos e objetos que a nossa exportação de productos agricolas não poderia pagar. $O$ desequilibrio cambial veio incentivar a industrialisação do Paiz, que poderia ter sido antecipada por uma politica commercial aberta e francamente protecionista, como tiveram os Estados Unidos e a
}

\footnotetext{
${ }^{397}$ Anais da Câmara dos Deputados, v. XVI(11/09/1935),p. 273.

${ }^{398}$ Anais da Câmara dos Deputados, v. XVI(11/09/1935), p. 281.

${ }^{399}$ Anais da Câmara dos Deputados, v. XVI(11/09/1935), p. 277.

${ }^{400}$ Anais da Câmara dos Deputados, v. XVI(11/09/1935), p. 277.
} 
Allemanha, e como teve a Inglaterra, emquanto precisou de tal politica para a formação de sua grande economia. ${ }^{401}$

Tratava-se de corrigir os problemas não por meio da liberalização comercial, mas por meio da regulação estatal. A prevalecerem os princípios do livre mercado, o Brasil permaneceria na crônica situação de país economicamente frágil, cujo câmbio se desvalorizava em decorrência da impossibilidade de suprir as demandas geradas pelo processo de civilização. A principal afinidade com as ideias de Karl Rodbertus parece estar nesse ponto: o Estado é um ente importante, que deveria regular o sistema econômico - nesse caso, por meio do protecionismo.

$\mathrm{Na}$ parte final de seu discurso, Simonsen fez uma descrição histórica das políticas comerciais aplicadas pela França, Inglaterra e Estados Unidos, para mostrar que esses países foram protecionistas sempre que houve necessidade de defender suas economias nacionais. No momento em questão, os anos de crise da década de 1930, que trouxe consigo o desmantelamento do padrão-ouro, vários países estavam justamente aplicando medidas de proteção: era o período das desvalorizações cambiais competitivas ou desvalorizações do tipo "empobreça-o-próximo". 402

A ênfase dessas descrições históricas recaía sobre a descrição da política comercial norteamericana, que, segundo Simonsen, era claramente orientada para a defesa dos interesses nacionais do país. Nada mais natural: o ponto de vista da economia nacional deveria prevalecer sobre o ponto de vista cosmopolita, assim como postulava Adolph Wagner. Equivocada era, para Simonsen, a política comercial brasileira que, em contraste, se orientava pelo livre-cambismo, em detrimento da defesa dos interesses das indústrias nacionais.

Simonsen retomou, para demonstrar esse equívoco histórico das políticas comerciais brasileiras, a história das políticas tarifárias e alfandegárias aplicadas no Brasil: da abertura dos portos, passando pela tarifa Alves Branco e pelas revisões do Segundo Reinado, até a adoção da quota-ouro no início da República, o Brasil não teria seguido, segundo Simonsen, uma rota coerente de apoio às suas atividades internas de transformação.

Denunciados os primeiros tratados de commercio, não soubemos manter uma orientação continua e conveniente em politica aduaneira. Nas agitações politicas em que vivíamos sujeitos ás influencias de grandes interesses num meio ainda não bem chrystallizado, as reformas das tarifas aduaneiras succederam-se umas sobre as outras, em medidas precipitadas ou em contra-marchas desastrosas. Emquanto os Estados Unidos tinham o animo bastante forte para resistir a taes investidas nós não comprehendemos o problema economico brasileiro, e seguimos a nossa evolução, obedecendo aos determinismos economicos do meio, ou ás directrizes que nos eram impostas pelas politicas commerciaes das economias de outros povos. ${ }^{403}$

\footnotetext{
${ }^{401}$ Anais da Câmara dos Deputados, v. XVI(11/09/1935),p. 278.

${ }^{402}$ EICHENGREEN, Barry. A globalização do capital. São Paulo: Ed. 34, 2000. p. 127.

${ }^{403}$ Anais da Câmara dos Deputados, v. XVI(11/09/1935), p. 303.
} 
Aparecia no discurso de 1935 o procedimento que ajudaria a moldar a interpretação simonseniana da história econômica do Brasil, que ganharia expressão mais consolidada dois anos depois com a publicação de seu livro clássico: a interpretação da história a partir do projeto político industrialista. No caso do discurso de 1935, o objetivo político é o protecionismo: a peça visava a contestar a cláusula de nação mais favorecida, concedida aos EUA pelo Tratado. O Brasil não deveria aceitar as condições do acordo, porque eram lesivas à indústria - e a indústria era, para Simonsen um imperativo histórico de um povo que se civiliza, progride, e não consegue fazer frente às suas necessidades de importação exportando apenas um único produto primário.

Em síntese, pode-se dizer que Simonsen introduziu conceitos tomados de economistas ligados a uma tradição nacionalista e protecionista alemã, formada nas tensões referentes à unificação da Alemanha e à ascensão desse país a potência industrial, para dar solidez e legitimidade ao seu discurso, que é protecionista e nacionalista, no sentido específico do nacionalismo já referido: associação entre progresso da indústria e desenvolvimento da nação. A cláusula de nação mais favorecida não seria a solução para os desequilíbrios externos brasileiros: a industrialização já se pusera em marcha como solução historicamente imperativa para a crônica ausência dos produtos necessários para sustentar a evolução de um povo que se civiliza.

O tipo de apropriação feita por Simonsen diferencia seu discurso da defesa da indústria feita por seus pares no Legislativo, ligados aos interesses industriais, cujos argumentos eram de cunho mais moral e apologético. Outros membros da bancada industrialista, classistas ou não, participaram das discussões, com destaque para Paulo Assumpção, então presidente da FIESP, e Vicente Galliez, então secretário-geral do CIB. Ambos trouxeram, para leitura no plenário, extensos artigos, recheados de elementos do ideário industrialista da década de 1930. Muitas das ideias que defenderam - em especial a associação direta do interesse nacional ao interesse da indústria nacional e a reivindicação de uma política comercial protecionista eram semelhantes às defendidas por Simonsen.

De maneira geral, as posições expressas por estes dois representantes da indústria se assemelhavam àquelas expressas por Simonsen. De fato, o que se nota é a presença de argumentos em favor do protecionismo e da defesa da indústria nacional, fundamentadas na associação direta entre o interesse nacional e os interesses da indústria, em seus discursos. Contudo, tal associação era feita por vezes com referência a setores específicos da indústria. Galliez, por exemplo, afirmou: “[o] Tratado facilitará a entrada de uma confecção que virá 
sacrificar os legítimos interesses do país" ${ }^{404}$. A associação do interesse nacional aqui se faz à prosperidade da indústria têxtil, mais especificamente a de camisas de algodão. Simonsen, por sua vez, procurava enfatizar a unidade de interesses de toda a indústria e desta com os demais setores da economia.

A reivindicação, por parte de Galliez e de Assumpção, de políticas de promoção da indústria também parece mais simples, focada na exigência de "tarifas inteligentemente protecionistas" e não meramente "alfandegárias". ${ }^{405}$ Simonsen, por seu turno, procurou formular sua proposta de defesa da indústria nacional em termos mais abrangentes, incluindo a necessidade de medidas de planejamento institucionalizado, tais como a criação de um órgão coordenador (o "Instituto Nacional de Exportação"), para orientar a política comercial do país. ${ }^{406}$ Um dos elementos mais marcantes nas participações de Galliez e Assumpção era a construção da ideia da legitimidade da indústria nacional. Esta preocupação se justificava na medida em que a elite industrial vinha, há muito, sofrendo ataques de políticos e intelectuais, em função de oposições de interesses que por vezes se estabeleceram quanto a certas questões de política econômica. Tais ataques, de cunho moral, visavam deslegitimar as reivindicações políticas dos industriais - como a de uma política de proteção alfandegária. Consistiam, em geral, em considerar boa parte da indústria local como "artificial", 407 ou em atacar os "privilégios" da indústria, quanto à política tarifária.

A fim de avançar suas demandas e, ao mesmo tempo, construir um novo consenso em torno de seus projetos políticos, líderes e intelectuais ligados a essa classe procuraram com afinco reconstruir as opiniões correntes sobre a indústria. Galliez, por exemplo, afirmou no plenário: "Não há indústrias fictícias no Brasil, nem em parte alguma. Toda atividade que incorpora riqueza ao patrimônio nacional é legítima". ${ }^{408} \mathrm{E}$ "convém salientar que o Brasil possui produção industrial tão grande quanto a produção agrícola". ${ }^{409}$ Um efusivo e emocional apelo, para que a indústria nacional fosse colocada em "pé de igualdade" com os demais setores, foi a contribuição mais destacada de Paulo Assumpção para o debate:

Quero apenas opor, em nome dos industriais, um basta à arrogância impertinente dos que nos combatem (...). Não somos traficantes de coisas ilícitas, nem entraves ao desenvolvimento de qualquer outra fonte de produção (...), exigindo para nós o respeito igual aos que mais o merecem. Já estamos cansados em consentir que sobre nossas costas extravasem as culpas e as consequências dos erros que não praticamos.

\footnotetext{
${ }^{404}$ Anais da Câmara dos Deputados, v. XVI (10/09/1935), p. 199.

${ }^{405}$ Anais da Câmara dos Deputados, v. XVI(10/09/1935), p. 200-201.

${ }^{406}$ Anais da Câmara dos Deputados, v. XVI(11/09/1935), p. 273.

${ }^{407}$ Era considerada "indústria artificial" aquela cujas matérias primas e insumos só pudessem ser obtidos por meio de importações. Esses foram os termos que opuseram os primeiros industrialistas brasileiros, como Amaro Cavalcanti, Serzedelo Correia e Jorge Street, a seus adversários agraristas. Sobre esse ponto ver LUZ, 1975.

${ }^{408}$ Anais da Câmara dos Deputados, v. XV (09/09/1935), p. 142.

${ }^{409}$ Anais da Câmara dos Deputados, v. XV (09/09/1935), p. 149.
} 
Se não soubemos realizar o milagre de industrializar o Brasil sem o sacrifício de uma tarifa protecionista, podemos, entretanto, alinhar aos olhos da Nação, cifras que, num período de quinze anos decuplicaram o valor de nossa produção (...). Essas cifras irrespondíveis e impressionantes dão-nos o direito que ora estamos exigindo. ${ }^{410}$

Como se pode ver na passagem acima, Assumpção tomava para si a defesa moral da indústria. $\mathrm{O}$ crescimento do produto seria o argumento legitimador, pois invalidaria a tese de que as indústrias nacionais seriam meramente parasitárias.

A principal especificidade da participação de Roberto Simonsen no referido debate, que marca o seu distanciamento com relação aos demais representantes dos industriais na Câmara, é, num primeiro plano, o nível mais aprofundado de suas reflexões e o fato de que, enquanto o tom dos discursos dos demais líderes industriais foi marcado por um viés moral e prático, a argumentação de Simonsen se revestia da preocupação em apresentar-se como "científica". Esse aspecto está certamente relacionado com sua formação técnica em Engenharia, bem como à forte influência que sofreu de vertentes positivistas, ligadas a um polo cientificista do campo intelectual brasileiro. ${ }^{411}$

Num segundo plano, Simonsen demonstrava possuir um arcabouço de pensamento econômico mais rico e estruturado, referenciado em aportes de ideias presentes nos debates econômicos do exterior, que não se limitavam às mais difundidas teorias do protecionismo, como as de Friedrich List e Mihail Manoilescu. Os aportes de Rodbertus e Wagner são exemplos dessa diversidade de referências e contribuem para a maior sofisticação do pensamento de Simonsen, que vai além de considerações mais práticas e imediatas quanto aos interesses da indústria, para chegar à conformação de um corpo de ideias econômicas particular.

\subsection{Planejamento: a controvérsia, antecedentes e contexto}

A chamada "controvérsia do planejamento", o debate com Eugênio Gudin entre os anos 1944-45, é um dos mais conhecidos momentos da trajetória de Simonsen. Os pareceres emitidos neste debate pertencem a seus textos mais lidos e emblemáticos, ao lado do livro História econômica do Brasil. Simonsen integrava, na ocasião da troca de pareceres com Gudin, o Conselho Nacional de Política Industrial e Comercial e portanto estava numa posição de relativa proximidade com o centro de tomada de decisões do Executivo federal. A mensagem central dos textos produzidos com o objetivo de institucionalizar a planificação econômica no Brasil é que os entraves ao progresso econômico nacional só seriam superados

\footnotetext{
${ }^{410}$ Anais da Câmara dos Deputados, v. XVI (10/09/1935), p. 212.

${ }^{411}$ MAZA, 2004, p. 33-65; BEIRED, José Luis Bendicho. Sob o signo da nova ordem: intelectuais autoritários no Brasil e na Argentina (1914-1945). São Paulo: Loyola, 1999. pp. 17-68.
} 
por meio de um planejamento que, intencionalmente, mudasse os rumos seguidos pela economia brasileira até então. Pretende-se mostrar que esse tipo de proposta está relacionado com a interpretação que Simonsen construiu da história do Brasil. Somente a industrialização poderia conduzir o Brasil à condição de país rico - e esse processo era histórico: nada havia que prendesse o país a desenvolver apenas o setor agrícola de sua economia. Dessa forma, a industrialização poderia ser induzida pelo Estado, poderia ser planejada, de forma a mudar os rumos da evolução econômica do Brasil. Veremos como esta forma de abordar o problema entrava em conflito com as propostas de Eugênio Gudin, que partia da perspectiva da economia, de matriz neoclássica, para interpretar a realidade brasileira. ${ }^{412}$

Assim como em momentos anteriores de sua obra, Simonsen recorreu, no debate do planejamento, a autores estrangeiros, para dar solidez aos seus argumentos e legitimidade ao seu discurso. No caso presente, Simonsen buscou a obra do economista Carl Landauer, alemão radicado nos Estados Unidos, que publicara um livro sobre planejamento econômico em 1944. Mostraremos também que o tipo de discussão feita por Simonsen, calcada no estudo da história e do atraso econômico como fenômeno histórico - e não como resultado de algum tipo de dotação ou vocação - estava em sintonia com leituras como a do autor russo Sergei N. Prokopovich.

A questão da organização e da racionalização da produção estava presente na obra de Simonsen, desde os primeiros textos, relacionados com as questões da Companhia Construtora de Santos e da otimização do trabalho, diante das restrições impostas pela Primeira Guerra. Ao longo dos anos 1930, houve uma preocupação em estender essa ideia da produção racional e controlada por normas ao conjunto da economia. A participação de Simonsen na fundação do Instituto de Organização Racional do Trabalho (IDORT), em 1931, é uma mostra dessa dimensão de sua atuação: Simonsen foi, certamente, um dos pioneiros da difusão do taylorismo no Brasil. Ainda que suas preocupações intelectuais se diversificassem ao longo dos anos 1930, levando-o a abordar temas como a história econômica e a teoria do comércio internacional, a questão da generalização da organização científica do trabalho continuou permeando os textos e discursos de Simonsen, como é o caso de sua contribuição à Jornada Contra o Desperdício de Espaço, promovida em dezembro de 1938 pelo IDORT.

Observo ainda, com viva satisfação, que diversos engenheiros, que naquela empresa [a Companhia Construtora de Santos], tiveram os seus primeiros postos de responsabilidade na vida profissional, hoje aqui trabalham pelo engrandecimento do

\footnotetext{
${ }^{412}$ A discussão feita aqui, acerca da controvérsia do planejamento, beneficia-se de pesquisa realizada anteriormente, cujos principais resultados estão consignados em texto de 2011. Ver BRUZZI CURI e CUNHA, 2011.
} 
IDORT, para onde trouxeram aquela orientação, procurando difundi-la e desenvolvê-la no interesse geral da comunidade. ${ }^{413}$

Alguns textos, presentes na coletânea Ensaios sociais, politicos e econômicos (1943) enquadram-se nessa perspectiva de racionalização do trabalho em nível mais amplo. Ganhava importância a institucionalização da organização científica do trabalho, por meio de órgãos como o já referido IDORT e a Associação Brasileira de Normas Técnicas (ABNT), fundada em 1940. Em discurso pronunciado em 1941, por ocasião da $4^{a}$ reunião da ABNT, em São Paulo, Simonsen reiterou a importância da padronização produtiva realizada pela Associação.

\begin{abstract}
Iniciada modestamente, pelas primeiras convenções de laboratórios e atividades interessadas, a campanha pela padronização dos métodos de ensaios e de pesquisas já evolveu, em movimentação nacional, integrando-se numa associação de normas técnicas, que, limitando por enquanto sua atuação, abrange, no entanto, em seus propósitos: o aperfeiçoamento permanente e progressivo da técnica, da indústria e da engenharia em nosso país. ${ }^{414}$
\end{abstract}

Embora relacionado com essa ideia de produção planejada e organizada, o planejamento de que se trata nesta parte do trabalho é mais abrangente: está relacionado com a organização da economia nacional, isto é, trata-se do planejamento não mais no âmbito da produção industrial, mas, sim, no âmbito do Estado. O Estado brasileiro modificou-se na Era Vargas, sobretudo no Estado Novo, na direção da construção de um aparato de intervenção e planejamento das atividades econômicas. Esse movimento esteve relacionado com processos históricos mais amplos, que alçaram o planejamento econômico a um lugar de proeminência.

Esse reforço do aparelho intervencionista estatal está associado ao fato de que o Estado liberal - e a ideologia a ele associada - atravessava um período de crise mundial no momento em questão. As primeiras décadas do século XX foram marcadas por ondas revolucionárias, pela ascensão de regimes totalitários centralizados e por uma atitude de resistência com relação ao livre mercado. O aparelhamento do Estado no Brasil, parte do processo de transição capitalista, pode ser visto como desdobramento particular de um processo maior de reconfiguração do capitalismo mundial e de alterações radicais no jogo político internacional. Na primeira metade dos Novecentos, o planejamento econômico-administrativo se tornou, em nível internacional, um instrumento de considerável importância para a direção das economias, capitalistas ou socialistas. Hobsbawm assinala que o século XX foi marcado, em seu início, por uma "era da catástrofe", isto é, 31 anos de um processo entrecortado de guerras e revoluções que vai da eclosão da Primeira Guerra Mundial, em 1914, à rendição incondicional do Japão em 1945.

\footnotetext{
${ }^{413}$ SIMONSEN, Roberto. Ensaios sociais, políticos e econômicos. São Paulo: FIESP, 1943. (abreviado como ESPE). Essa coletânea, publicada por Simonsen em 1943, reúne textos, em sua maioria discursos e outros textos curtos, escritos pelo autor nos anos 1930 e início dos anos 1940.

${ }^{414}$ SIMONSEN, Roberto. "A indústria e as pesquisas tecnológicas". [1941]. IN: ESPE, p. 231.
} 
O envolvimento em conflitos bélicos pressupõe que nações se transformem em economias de guerra e, dessa forma, surge o problema fiscal fundamental de como deveria ser financiado o conflito. Nesse contexto, os Tesouros Nacionais e ministérios de Finanças eram vistos como comandantes das economias de guerra. "se se tinha de travar a guerra em escala moderna, não só seus custos precisavam ser levados em conta, mas sua produção - e no fim toda a economia - precisava ser administrada e planejada." ${ }^{415}$. Nos anos entreguerras, o mundo havia perdido a confiança na ortodoxia do livre mercado, mesmo porque os países capitalistas mergulharam numa crise sem precedentes, que acometeu todo o mundo ocidental. O Estado que emergiu na Rússia após a Revolução de 1917, a União Soviética, foi comparativamente menos atingido pela crise do que os países capitalistas, o que contribuiu para a desconfiança do mundo ocidental com relação ao livre mercado, sendo evidenciadas as possibilidades que a planificação econômica representava. Quando Simonsen e Gudin se defrontaram em debate, não há dúvida de que o planejamento econômico era uma questão que estava na ordem do dia.

A controvérsia de planejamento foi uma troca de pareceres, entre Roberto Simonsen e Eugênio Gudin, ocorrida entre 1944 e 1945. Roberto Simonsen era, neste momento, membro do Conselho Nacional de Política Industrial e Comercial (CNPIC) e Eugênio Gudin pertencia à Comissão de Planejamento Econômico (CPE). Criada em 1944, a Comissão de Planejamento Econômico era um órgão do Conselho de Segurança Nacional, que tinha como tarefa a elaboração de estudos gerais sobre economia brasileira e, em particular, de estudos de interesse militar. Tendo como referência a Coordenação de Mobilização Econômica, que fora criada em 1942 para o controle da situação atravessada pela economia brasileira ao longo da Segunda Guerra, a CPE deveria conceber a estrutura institucional que executaria o planejamento econômico.

O CNPIC, por seu turno, era vinculado ao Ministério do Trabalho, Indústria e Comércio, e compunha-se de representantes dos ministérios, das associações industriais e comerciais, de setores da burocracia econômica e de técnicos especialistas. Sua atribuição era o estabelecimento de princípios norteadores do desenvolvimento industrial brasileiro. Quando da criação do CNPIC, Roberto Simonsen, já participante do conselho consultivo da Coordenação de Mobilização Econômica, foi apontado como membro representante dos industriais. Foi no âmbito do CNPIC que teve início a controvérsia do planejamento. O órgão deveria tratar da questão de como a planificação seria, de fato, institucionalizada no Brasil. Não havia, até então, no âmbito da administração pública brasileira, um órgão que

${ }^{415}$ HOBSBAWM, 1995, p. 53. 
congregasse todas as esferas de planejamento econômico e que coordenasse, de forma sistemática, as ações do governo.

Foram debatidas duas propostas para a institucionalização do planejamento. Simonsen propunha que o próprio CNPIC se tornasse o órgão máximo do planejamento econômico no Brasil, diretamente subordinado à Presidência da República. A execução do plano seria levada a cabo por uma Junta de Planificação Econômica, formada por comissões de representantes das classes produtoras e de técnicos em economia, demografia e outras áreas. A proposta da Seção Técnica do Conselho, atribuída a Rômulo de Almeida, defendia a criação de um Conselho Nacional, presidido pelo presidente de República e composto pelos ministros, militares de alta patente e outras personalidades. O Conselho seria resultante da fusão do Conselho Federal de Comércio Exterior com o Conselho Técnico de Economia e Finanças.

O projeto final, entregue ao presidente, era uma junção das duas propostas. A proposta, entretanto, não foi aprovada. Enviada anteriormente para a Comissão de Planejamento Econômico, suscitou o debate entre Roberto Simonsen e Eugênio Gudin, que se centrou em torno da questão da viabilidade do planejamento e de sua execução. A CPE foi criada justamente quando se desenrolavam as discussões no CNPIC, o que sugere que tenha sido formada com o objetivo de contrabalançar os desenvolvimentos que ocorriam no âmbito do CNPIC. É instigante o fato de que o parecer de Roberto Simonsen tenha passado pela Comissão, mais especialmente pelas mãos de Gudin que era um renomado economista de inclinações liberais. ${ }^{416}$

Convém recuperar aqui alguns dados básicos sobre a trajetória de Eugênio Gudin até o momento da controvérsia, para que se possa ter uma ideia melhor do campo intelectual e político em que este economista se situava. A denominação recebida por Gudin de "patrono dos economistas brasileiros" é, em alguma medida, cabível, tendo em vista ter sido o primeiro a publicar um livro-texto brasileiro de economia e um dos primeiros a preocupar-se com o ensino formal da disciplina no país. Ademais, Gudin teve passagem importante no setor público, chegando a ocupar o Ministério da Fazenda no governo Café Filho (1954-55). Os parágrafos a seguir se referem a alguns pontos da trajetória de Gudin, que podem ajudar a compreender sua posição no debate da época.

Filho de pai descendente de negociantes franceses estabelecidos no Brasil, Gudin nasceu no Rio de Janeiro, em 1886. Graduou-se em engenharia civil pela Escola Politécnica do Rio de Janeiro, em 1905, tendo trabalhado para a Light e para a firma Dodsworth e Cia. em diversos projetos espalhados pelo país. Nos anos 1920, quando ainda atuava como

\footnotetext{
${ }^{416}$ VON DOELLINGER, Carlos. “Introdução”. IN: SIMONSEN, Roberto, GUDIN, Eugênio e VON DOELLINGER, Carlos. A controvérsia do planejamento na economia brasileira. $3^{\text {a }}$ edição. Brasília: IPEA, 2010. pp. 21-34.
} 
engenheiro, começou a manifestar interesse pela economia, estudando clássicos como Smith e Ricardo, além de Marshall e outros autores coevos, norte-americanos e europeus. Durante o primeiro governo Vargas, ocupou diversos cargos na administração estatal. O primeiro órgão de que participou foi a Comissão de Estudos Financeiros e Econômicos dos Estados e Municípios, criada pelo Ministério da Fazenda em 1931. Foi integrado, em 1937, ao Conselho Técnico de Economia e Finanças (CTEF) que pretendia centralizar o controle financeiro do país nas mãos do governo federal, no intuito de garantir à União a exclusividade das operações financeiras externas. Criado logo após a instauração do Estado Novo, o CTEF foi responsável por pela regularização do serviço da dívida externa, além de ter participado do debate sobre o crédito industrial. ${ }^{417}$

No I Congresso Brasileiro de Economia, realizado no Rio de Janeiro em 1943, com a participação de industriais adeptos de uma linha mais intervencionista como Simonsen e Euvaldo Lodi, Eugênio Gudin liderou a oposição liberal, que contestou a reivindicação dos congressistas de uma coordenação estatal das iniciativas econômicas. Gudin também desempenhou um papel importante na organização do ensino e pesquisa e economia no Brasil. Foi um dos idealizadores da criação do Centro de Estudos Econômicos da Fundação Getúlio Vargas, no Rio de Janeiro, que foi posteriormente transformado em Instituto Brasileiro de Economia (IBRE). A FGV tornou-se local privilegiado da produção de um conhecimento econômico voltado para a prática, isto é, para a criação de competências necessárias à condução da política econômica nacional. ${ }^{418}$

O debate direto com Simonsen se daria em 1945, com a redação de "Rumos de política econômica" ${ }^{419}$, em que Gudin criticava as propostas apresentadas por Simonsen no texto "A planificação da economia brasileira" ${ }^{420}$ Gudin propugnava uma redução gradual dos órgãos estatais de intervenção na economia, de forma a restabelecer a primazia da iniciativa privada e o livre jogo das forças de mercado. Nos anos 1950, Gudin contribuiu de forma marcante para a difusão, no Brasil, das ideias ligadas à economia do desenvolvimento, cuja discussão começava a ganhar corpo internacionalmente. Trouxe ao país economistas como Nurkse, Singer, Wallich, Kaldor, Viner, dentre outros, tendo promovido, em 1957, no Rio de Janeiro, a Conferência da Associação Econômica Internacional, com o tema do "Desenvolvimento

\footnotetext{
${ }^{417}$ KELLER, Vilma. "Eugênio Gudin”. IN: Dicionário histórico-biográfico brasileiro: pós-1930. 2 a edição. Rio de Janeiro: FGV/CDPDOC, 2001. pp. 2664-2669.

418 SAES, Alexandre; CYTRYNOVICZ, Roney; SAES, Beatriz; HESPANHOL, Giancarlo; BRUZZI CURI, Luiz Felipe. FIPE 40 anos. São Paulo: FIPE, 2013 (no prelo). p. 21.

419 GUDIN. Eugênio. "Rumos de política econômica" [1945]. IN: SIMONSEN, Roberto, GUDIN, Eugênio e VON DOELLINGER, Carlos. A controvérsia do planejamento na economia brasileira. $3^{\mathrm{a}}$ edição. Brasília: IPEA, 2010a.

${ }^{420}$ SIMONSEN, Roberto. "A planificação da economia brasileira" [1944]. IN: SIMONSEN, Roberto, GUDIN, Eugênio e VON DOELLINGER, Carlos. A controvérsia do planejamento na economia brasileira. $3^{\mathrm{a}}$ edição. Brasília: IPEA, 2010a.
} 
econômico da América Latina". 421

Com o suicídio de Getúlio Vargas, em 1954, e a formação do governo Café Filho, foi montado um gabinete ministerial que refletia tendências antigetulistas. $\mathrm{Na}$ área econômica, foram indicados Gudin para o Ministério da Fazenda e Otávio Bulhões para a presidência do Banco do Brasil. Bulhões era apoiado por Gudin e integrava a UDN, partido que fazia oposição ao governo Vargas. Uma das realizações mais importantes de Gudin à frente da pasta da Fazenda foi a implementação da Instrução 113 da SUMOC, em 1955, que facilitou a entrada de investimento estrangeiro no Brasil. Segundo vários autores, essa medida teria sido importante para assegurar o financiamento do Plano de Metas de Juscelino Kubitschek, que viria a ser implantado alguns anos depois. ${ }^{422}$ Gudin faleceu em 1986, no Rio de Janeiro. ${ }^{423}$

O pensamento de Eugênio Gudin é qualificado por Bielschowsky como pertencente à corrente "neoliberal" do pensamento brasileiro no período 1930-64. Esses liberais brasileiros são assim classificados pelo autor por distinguirem-se dos liberais convencionais, na medida em que admitiam certo grau de intervenção estatal em economias subdesenvolvidas como a brasileira. Embora concordassem que o grau de intervenção estatal deveria ser reduzido, não concordavam sobre o tamanho do apoio financeiro que o governo deveria conceder aos setores de infraestrutura. Eram unânimes ao discordar de que o investimento nesses setores fosse feito diretamente pelo governo: viam o capital estrangeiro como agente capitalista adequado nesses casos. Os traços principais dessa corrente seriam: apoio ao princípio de redução da intervenção estatal na economia, defesa de políticas de estabilização monetária e financeira e resistência contra medidas de suporte à industrialização. ${ }^{424}$

Inspirado por Viner e Haberler, Gudin empreendeu um esforço de recuperação de um princípio fundamental da economia clássica - de não intervenção estatal na Economia adaptando-o ao caso de economias subdesenvolvidas, em especial ao Brasil. Gudin não recusava a ideia de industrialização brasileira de forma simples, mas tinha, a respeito, uma argumentação complexa e atualizada. A principal hipótese teórica de sua argumentação era que a economia brasileira se encontrava em pleno emprego, o que tornava suas elaborações relativamente imunes a críticas de inspiração keynesiana.

Os fundamentos de suas convicções teóricas, até o momento do debate com Simonsen, estão consignados no livro de 1943, Princípios de economia monetária. Gudin era um liberal,

\footnotetext{
${ }^{421}$ BIELSCHOWSKY, Ricardo. "Eugênio Gudin”. Estudos avançados. [online]. vol.15, n.41. 2001. pp. 98-99.

${ }^{422}$ Sobre a Instrução 113 e o Plano de Metas ver LESSA, Carlos. Quinze anos de política econômica. $4^{\text {a }}$ edição. São Paulo: Brasiliense, 1983; e ORENSTEIN, Luiz e SOCHACZEWSKY, Antonio Claudio. "Democracia com Desenvolvimento". IN: ABREU, 1990.

${ }^{423}$ KELLER, 2001, pp. 2664-2669.

${ }^{424}$ BIELSCHOWSKY, 2000, pp. 37-38.
} 
mas estava ciente das qualificações necessárias aos seus princípios. Se aceitava o princípio do equilíbrio de máxima eficiência no caso de atuação livre das forças de mercado, concordava com as ideias de Keynes para explicar os períodos de depressão e admitia a ocorrência de crises com causas endógenas. Era defensor do Estado mínimo, mas admitia algum grau de intervenção na economia, por exemplo, para neutralizar depressões cíclicas. Destacam-se aqui três aspectos do pensamento de Gudin, articulados entre si, que podem ajudar a demarcar seu posicionamento no debate da época: a articulação entre desequilíbrio externo e inflação, a visão sobre os desafios colocados pelo atraso brasileiro e o posicionamento diante do protecionismo e do planejamento no Brasil. ${ }^{425}$

Em sua visão, era a inflação - e não as insuficiências do parque produtivo nacional - a principal responsável pelo desequilíbrio no balanço de pagamentos: a eliminação desta conduziria, inexoravelmente, ao equilíbrio externo, pois os valores das importações e exportações seriam interdependentes. Se houvesse, por exemplo, uma retração de importações decorrente de política tarifária, haveria um deslocamento de recursos para atividades internas, gerando superávit temporário no balanço de pagamentos e consequente apreciação cambial, que acabaria por desestimular as exportações. A diminuição "artificial" das importações, por meio de política protecionista, acaba por afetar as exportações e a eficiência alocativa do sistema: o resultado final é uma economia mais fechada, e menor. A inflação, vista como "excesso de dinheiro", nada mais significaria que uma pressão de demanda artificial sobre as importações, gerando desequilíbrios no balanço de pagamentos. ${ }^{426}$

Gudin era um economista preocupado com as economias atrasadas. Entendia, no entanto, que a teoria econômica era a mesma, para análise das economias pouco desenvolvidas ou industrializadas. Sua principal preocupação analítica era a adaptação de teoria econômica à realidade brasileira, o que fica claro no volume II de seus Princípios. Importava identificar as características principais das economias pouco desenvolvidas, que exigiam políticas distintas das aplicadas às economias centrais, com vistas a garantir a eficiência de mercado, em última instância. Haveria, para Gudin, diferenças significativas entre as economias, por exemplo, no que tange à sua vulnerabilidade:

\begin{abstract}
A doutrina clássica presumia uma relativa igualdade entre as economias dos países em apreço, quando, na realidade, do ponto de vista internacional, umas são muito mais vulneráveis do que outras: maior ou menor grau de internacionalidade, dependência, ou não de poucos produtos de exportação, procura elástica ou inelástica das exportações e importações, etc. ${ }^{427}$
\end{abstract}

Por causa dessas especificidades, o mecanismo automático de ajuste no balanço de

\footnotetext{
${ }^{425}$ BIELSCHOWSKY, 2000, p. 67.

${ }^{426}$ BIELSCHOWSKY, 2000, p. 68.

${ }^{427}$ GUDIN, Eugênio. Princípios de economia monetária. [1943]. $2^{\mathrm{a}}$ edição. Rio de Janeiro: AGIR, 1956. p. 272.
} 
pagamentos, que operaria no padrão-ouro, não funcionaria perfeitamente, sendo necessário aplicar políticas cambiais, tarifárias ou de controle quantitativo de importações: as políticas cambiais seriam preferíveis às tarifas alfandegárias que seriam, por sua vez, preferíveis às licenças para importações, vistas como uma intervenção excessiva do Estado, que poderia auferir para si benefícios do comércio exterior.

No caso específico do Brasil, Gudin postulava que a economia nacional estaria em pleno emprego e qualquer política industrializante tenderia a roubar fatores da agricultura, promovendo inflação e reduzindo a eficiência do sistema econômico. A posição de Gudin sobre a indústria e seu papel no desenvolvimento era baseada na ideia de que a economia brasileira sofria de baixa produtividade e pleno emprego (e não de especialização primária e desemprego) e de que indústria de baixa produtividade não é sinônimo de prosperidade. ${ }^{428} \mathrm{O}$ relevante seria aumentar a produtividade da agricultura, partindo-se para a implantação da indústria leve, à medida que a agricultura liberasse mão de obra, sendo a industrialização pesada relegada a um horizonte remoto. "Precisamos é aumentar nossa produtividade agrícola, em vez de menosprezar a única atividade econômica em que demonstramos capacidade para produzir vantajosamente". 429

A crítica de Gudin ao protecionismo brasileiro se referia à limitação dos níveis tarifários e aos prazos durante os quais seriam aplicadas políticas protecionistas. Aceitava o argumento listiano da indústria infante, mas alertava para a importância de se selecionar bem as indústrias a serem protegidas. Em outras palavras, não considerava o protecionismo como meio de se promover a industrialização. As referências ao tema continham sua mensagem de ceticismo quanto à possibilidade de se atingir alta produtividade na indústria brasileira. As tarifas elevadas gerariam lucros excessivos, desestimulando a elevação da produtividade. $\mathrm{O}$ sistema de licenças para importar seria ainda mais perigoso. Nas palavras de Gudin:

O regime de quotas e licenças prévias tem, naturalmente, o apoio dos partidários da economia planificada, como dos políticos que, empunhando as alavancas-chave do comércio exterior, exercem uma verdadeira ditadura sobre a economia do país.

O sistema de quotas e licenças pode ser uma etapa para o completo monopólio do comércio exterior pelo Estado. Verificado que os negócios de importação e exportação são altamente lucrativos, o Governo é tentado a recolher para si próprio os benefícios auferidos por aqueles a quem distribui as licenças. Na Rússia, que atingiu a última fase dessa evolução, o Estado tem o completo monopólio do comércio internacional. ${ }^{430}$

Embora o autor procure manter um tom puramente econômico e desvinculado de uma

\footnotetext{
${ }^{428}$ BIELSCHOWSKY, 2000, pp. 55-56.

${ }^{429}$ GUDIN. Eugênio. "Rumos de política econômica". [1945]. IN: SIMONSEN, Roberto, GUDIN, Eugênio e VON DOELLINGER, Carlos. A controvérsia do planejamento na economia brasileira. $3^{\mathrm{a}}$ edição. Brasília: IPEA, 2010. p. 106.

${ }^{430}$ GUDIN, [1943] 1956, p. 290.
} 
filiação ideológica específica, as convicções políticas de Gudin estavam articuladas à proposição de medidas econômicas: seu ataque ao planejamento estava imbuído de uma série de princípios relativos ao ideário liberal e de uma clara associação entre economia planejada e socialismo soviético.

Com esse sumário sobre as posições teóricas e políticas de Eugênio Gudin, tem-se uma melhor dimensão de que a criação da Comissão de Planejamento Econômico (CPE), em 1944, em meio ao desenrolar das discussões no âmbito do Conselho Nacional de Política Industrial e Comercial certamente não foi um acontecimento fortuito: as propostas de Simonsen e Rômulo de Almeida, encaminhadas a Gudin, certamente seriam recebidas com reticência. As interpretações mais comuns do episódio apontam que a CPE teria sido criada justamente para neutralizar o radicalismo da posição industrialista e nacionalista de Roberto Simonsen. Alternativamente, seria uma tentativa da parte de Vargas de não perder o controle da política econômica ou mesmo de encontrar uma "via intermediária" para o desenvolvimento da economia brasileira, com elementos da posição intervencionista pró-indústria e elementos de uma concepção mais liberal. ${ }^{431}$

Essas explicações certamente contêm elementos relevantes, mas Sônia Draibe chama a atenção para o fato de que tais interpretações deixam de lado um aspecto essencial da questão: os limites da autonomia de um Estado que, neste episódio, revelava sua face frágil. Se, desde meados dos anos 30, estavam presentes, na lógica da expansão do aparelho do Estado, os requerimentos de intervenção, planificação e aprofundamento dos controles econômicos, abrindo espaço para a ação industrializante, também é certo que na conjugação de forças que sustentava o Estado encontravam-se fortes elementos contrários à industrialização, à nacionalização, à intervenção, ao planejamento. ${ }^{432}$ As divergências, no entanto, não devem ser entendidas num esquema polar industrialistas versus anti-industrialistas, pois nem sempre houve um alinhamento claro em torno das questões postas pela industrialização. Mesmo entre os setores considerados industrialistas - como o empresariado industrial, a nova burocracia e os militares interessados em projetos de defesa nacional - havia divergências quanto ao papel da empresa pública, aos meios de financiamento e ao papel do capital estrangeiro. O Estado, representado pela própria Presidência da República, agia muitas vezes de forma a dirimir os conflitos, mas esbarrava sempre na barreira intransponível de suas forças instáveis de sustentação. O episódio do debate parlamentar a respeito do Tratado de 1935, por exemplo, mostrou como era complexo o quadro de posicionamentos políticos em torno da questão

\footnotetext{
${ }^{431}$ VON DOELLINGER, 2010, p. 29.

${ }^{432}$ DRAIBE, Sônia. Rumos e metamorfoses um estudo sobre a constituição do Estado e as alternativas de industrialização no Brasil (1930-1960). Rio de Janeiro: Paz e Terra, 1985. pp. 114-119.
} 
relativa ao tipo de inserção no comércio internacional que o Brasil deveria buscar: nesse caso, como vimos, pesquisas apontam para o fato de que a oposição de interesses era entre industriais e membros da burocracia estatal, dois grupos considerados "nacionalistas" ou “industrialistas" nas generalizações mais amplas.

A origem da manobra do governo Vargas em 1944-45 - e do próprio debate que ela acabou por gerar - deve ser buscada, nas condições estruturais e conjunturais da economia e da sociedade brasileiras. Tratava-se de um país em fase de implantação do capitalismo, um processo de transição acelerado e, em parte, determinado pela crise dos anos 1930. Esse processo se deu sobre bases econômicas e sociais profundamente heterogêneas. O arranjo institucional-político resultante é um Estado de compromisso, que abriu espaço para a representação da burguesia industrial no âmbito do próprio Executivo federal: a presença de Simonsen no CNPIC é uma evidência desse tipo de participação política. Esse tipo de representação, todavia, pode ser visto como indício de fragilidade: trata-se de uma burguesia industrial em processo de afirmação hegemônica, para a qual a representação política no âmbito de um Estado autoritário é fundamental. Se o Estado era centralizado e sua ação era, em vários aspectos, industrializante, nacionalista e construtora da ordem capitalista moderna, ele era limitado pelas próprias condições que o geraram.

Do ponto de vista mais conjuntural, o contexto de guerra teria ajudado, de acordo com Pedro Dutra Fonseca, o Estado ditatorial varguista, criando condições propícias para a difusão do nacionalismo, da centralização de poder e do planejamento. Mesmo adversários do planejamento passaram a admitir sua necessidade, reconhecendo como legítimas as ações do governo no sentido de assegurar o Estado nacional integrado, que asseguraria a continuidade do processo de acumulação capitalista. Se a situação de guerra foi favorável à difusão do planejamento e à aceitação da forte presença do Estado na economia, o desenrolar do conflito também propiciou o questionamento desses processos. Em 1942, a entrada do Brasil na guerra, ao lado das potências ocidentais liberal-democráticas, deu alento a oposições ao regime do Estado Novo, tanto de cunho liberal, quanto de tendências à esquerda. Ademais, de acordo com a Constituição de 1937, deveria haver eleições em 1943 - e Vargas prometia eleições somente com o fim da guerra. Essa situação gerou descontentamento entre parcelas das classes dominantes, com respaldo de grupos médios urbanos. A partir de 1943, a aliança política contrária Vargas começava a ganhar força, com a articulação da UDN a setores da burguesia industrial e financeira, exportadores e mesmo parte da esquerda socialista independente. Neste mesmo ano, foi redigido o Manifesto dos Mineiros, em que políticos tradicionais de Minas Gerais reivindicavam a imediata redemocratização do país. A 
conjuntura em que ocorreu o debate foi, portanto, complexa. Em 1944-45, o desfecho da guerra era uma questão de tempo e, com o final do conflito, deixaria de existir o esteio usado por Vargas para a manutenção do Estado Novo. ${ }^{433}$ Em suma, se o planejamento estava na ordem do dia, devido à situação conjuntural, o questionamento dos corolários do Estado forte e intervencionista se fazia presente na realidade brasileira.

A controvérsia do planejamento se distingue dos debates brasileiros sobre industrialização da primeira metade do século XX, por conter uma discussão mais consistente relacionada ao desenvolvimento brasileiro. O pensamento de Simonsen, de forma mais ampla, apresentava especificidades que qualificam o quadro geral de um desenvolvimento teórico pouco consistente nas elaborações dos defensores da industrialização, na primeira metade do século XX no Brasil. No intuito de mostrar como essas especificidades aparecem no âmbito da controvérsia do planejamento, ressaltaremos as sintonias das contribuições de Simonsen com discussões internacionais do período.

Para capturar essa sintonia dos textos de Simonsen com debates econômicos coevos, são destacados dois autores: Sergei Nikolaievich Prokopovich e Carl Landauer. S. N. Prokopovich foi um economista russo, nascido em 1871, nas proximidades de São Petersburgo. Estudou inicialmente na Academia de Agricultura Petrov, em Moscou, da qual foi expulso por suas atividades estudantis contrárias ao governo czarista. Prokopovich foi influenciado pelo marxismo, embora possa ser classificado como um representante do socialismo revisionista na Rússia pré-revolucionária. Foi influenciado pelos Narodnik e pelo movimento trabalhista russo. ${ }^{434}$ Ainda antes da Revolução, passou vários anos na Europa ocidental, onde se juntou à "União de Social-Democratas Russos no Estrangeiro". Na virada do século, retornou à Rússia e foi admitido como professor de economia na Universidade de Moscou, onde fez uma tentativa exitosa de estimar o produto nacional russo, além de dedicarse à pesquisa relacionada aos principais problemas econômicos da Rússia pré-1917. Sua tendência política, que apoiava a organização social, econômica e política da classe trabalhadora, sem conclamá-la à ação revolucionária, ficou conhecida como "marxismo legal”. Com a Revolução de Fevereiro, Prokopovich assumiu, a partir de julho de 1917, o Ministério de Indústria e Comércio e, posteriormente, o Ministério do Abastecimento. A despeito da ascensão dos bolcheviques, Prokopovich, contrário a esta tendência, permaneceu na Rússia, chegando a ter papel central no combate à crise de fome em 1921-22. Foi deportado em 1922, seguindo para Berlim, Praga e Genebra. Nesta cidade, fundou um

\footnotetext{
${ }^{433}$ FONSECA, 1987, pp. 283-284 e pp. 313-321.

${ }^{434}$ Os Narodnik ou populistas russos eram socialistas, que, inspirados por ideias românticas, pregavam a volta à vida no campo, nas décadas de 1860 e 1870.
} 
instituto de pesquisa chamado "Gabinete Econômico", onde investigou o desenvolvimento da URSS até sua morte em $1955 .{ }^{435}$

É dessa fase em Genebra que data o livro sobre a industrialização dos países atrasados, analisado aqui: L'industrialisation des pays agricoles et la structure de l'économie mondiale après la guerre, de 1945. O livro refletiria a tendência, perceptível nos economistas da Liga das Nações em finais da Segunda Guerra, de considerar que as economias de países pobres e agrícolas deveriam industrializar-se em alguma medida, por não possuírem excedentes agrícolas suficientes para garantir as importações de manufaturas necessárias. ${ }^{436} \mathrm{O}$ principal objeto de estudo de Prokopovich, ao longo de sua carreira, foi o desenvolvimento da União Soviética, tendo analisado com profundidade os Planos Quinquenais. Viria daí sua preocupação com o planejamento econômico e a industrialização pesada. A partir dos anos 1930, a ênfase do pensamento de Prokopovich passaria a ser o planejamento baseado em políticas econômicas racionais, que teria como pano de fundo a industrialização pesada e a democratização política. Prokopovich chegou a diferenciar, em estudo de 1952, o planejamento nos países avançados, cujo objetivo deveria ser lutar contra monopólios privados e combater crises econômicas, do planejamento em países atrasados como a Rússia, cuja meta deveria ser o desenvolvimento das forças produtivas nacionais, a luta contra o analfabetismo e a baixa produtividade do trabalho e a criação de indústrias nacionais. Suas propostas tinham traços nacionalistas: a aceitação do sistema soviético derivava da percepção de que a URSS estava promovendo uma transformação nacionalista, uma emancipação com relação às potências ocidentais. Prokopovich faleceu em Genebra, em $1955{ }^{437}$

Carl Landauer, o outro autor estrangeiro presente na argumentação de Simonsen, nasceu em Munique, em 1891, tendo obtido o grau de doutor em Heidelberg. Trabalhou vários anos para o periódico Der Deutsche Volkswirt (“O economista alemão”), o mais importante da República de Weimar, na área de economia. Foi professor da Universidade Comercial de Berlim até 1933. Membro do Partido Social-Democrata Alemão desde 1912, foi um dos seus principais teóricos na área econômica. Defensor da democracia, participou ativamente da luta de seu partido contra o curto Governo Soviético Bávaro de 1919 e da oposição ao regime nazista, que o obrigou a deixar sua terra natal. Em 1934, associou-se ao Departamento de Economia da Universidade da Califórnia, Berkeley, onde lecionou cursos e seminários sobre

\footnotetext{
${ }^{435}$ Sobre a vida e a trajetória de Prokopovich, ver KOJIMA, Shuichi. "Exiled Russian economists and the USSR: Brutzkus and Prokopovich". IN: BARNETT, Vincent e ZWEYNERT, Joachim (ed.). Economics in Russia: studies in intellectual history. Aldershot: Ashgate Publishing, 2008; e CHINYAEVA, Elena. Russians outside Russia: the émigré community in Czechoslovakia, 1918-1938. München: Oldenbourg Verlag, 2001.

${ }^{436}$ Ver LOVE, 2008, p. 402. As biografias de Prokopovich não referem que ele tenha trabalhado na Liga das Nações, mas é possível que tenha sido influenciado pelo tipo de conhecimento que se produzia na instituição, até porque residia em Genebra.

${ }^{437}$ KOJIMA, 2005, pp. 134.
} 
movimentos de reforma social, sistemas econômicos comparados e diversas outras áreas da economia.

A obra Theory of national economic planning, de 1944, foi o primeiro livro americano de Landauer. A ele, seguiram-se European socialism (1959), um livro enciclopédico, e Germany, illusions and dilemmas (1969), em que estavam presentes suas preocupações com a terra natal. Landauer teria contribuição importante para a teoria do socialismo de mercado competitivo, tendo sido membro do grupo dos "socialistas de mercado" alemães (Marktsozialisten) que pretendiam formular a teoria de uma economia socialista comprometida com a eficiência, a equidade distributiva e a democracia política. A contribuição está sumariada no livro Planwirtschaft und Verkehrswirtschaft ("Economia planificada e economia de mercado"), de 1931. A economia socialista admitida por Landauer era baseada em incentivos materiais, retendo alguma desigualdade de rendas e alguns conflitos de interesse. O modelo incluía preços flexíveis, aversão à burocracia e ao monopólio e planejamento econômico. Landauer faleceu na Califórnia, em 1983. ${ }^{438}$

Os dois autores apresentados possuem afinidades dignas de destaque. Ambos deixaram seus países natais exilados, tendo-se radicado em países onde encontraram certa estabilidade política, que lhes permitiu observar a Segunda Guerra e suas consequências. Tanto Prokopovich quanto Landauer dirigiram algum tipo de atenção para os seus países de origem, a Rússia e a Alemanha, que emergiam do conflito mundial em situação difícil. É comum aos dois a crença na ordem democrática e o ataque, com grau variável de intensidade, a regimes não democráticos, dos quais ambos fugiram. Acreditavam que era preciso garantir, por meio do planejamento e da intervenção estatal no âmbito do capitalismo, a melhoria das condições econômicas para que não houvesse as instabilidades que levaram às guerras.

No que se refere à discussão das ideias relativas ao atraso econômico, uma diferença importante entre esses dois autores é a atenção que dirigem ao mundo atrasado. Prokopovich reconhecia a Rússia como país atrasado, diferente das grandes potências europeias, e chega a dedicar um livro à industrialização dos países "agrícolas". Landauer se preocupava com o socialismo e as especificidades de cada sistema econômico, mas sua atenção estava mais voltada para os países centrais, aí incluída a própria União Soviética. A principal contribuição de Landauer, à qual Simonsen se reportou, é a de apresentar argumentos, baseados na teoria econômica, para o planejamento, ao lado de considerações sobre as implicações do uso dessa técnica para a estabilidade democrática de forma geral. Landauer não discutiu as especificidades do atraso econômico de países como o Brasil.

\footnotetext{
${ }^{438}$ Sobre a trajetória de Landauer, ver GROSSMAN, Gregory; GRETHER, Ewald T.; LETICHE, John. “1985, University of California: In Memoriam.” Berkeley: University of California Academic Senate, 1985.
} 
De volta ao debate Simonsen-Gudin, trataremos agora de alguns trechos da controvérsia, com o intuito de mostrar, no texto, a especificidade da abordagem de Simonsen, relacionada às suas sintonias internacionais e ao tipo de interpretação da realidade brasileira subjacente a seus argumentos. Trata-se de uma interpretação baseada na história econômica, norteada pelo nacionalismo industrialista, que via nos ciclos econômicos processos de criação de riqueza efêmera e, na indústria, a possibilidade de criação de riquezas permanentes para o país. Esse tipo de interpretação da economia brasileira como construção histórica abre caminho para que se proponha o planejamento como forma de se alterar o curso dos acontecimentos, superando o atraso econômico. É uma abordagem diferente da de Gudin, que parte de um arcabouço ahistórico de compreensão da realidade brasileira.

Gudin interpretava sua conjuntura presente a partir de uma tradição metodológica neoclássica, herdada da revolução marginalista. Os problemas da economia brasileira são vistos como problemas alocativos, mais do que como problemas relacionados a uma evolução histórica ou a uma situação político-cultural específica. As considerações de Gudin acerca dos processos que levaram à conjuntura que observava - o final da Segunda Guerra - estão espalhadas em suas duas contribuições ao debate com Simonsen. Em sua primeira resposta a Simonsen, Gudin aborda o tema, ao tentar desconstruir a "mística do plano". No intuito de destacar o caráter "anacrônico" da planificação e suas desvantagens em relação ao livre mercado, Gudin comparava o mercantilismo, que exigia boa dose de planificação e intervenção estatal, à economia liberal, baseada no interesse dos indivíduos.

A doutrina do laissez-faire, a cujo impacto rapidamente ruiu o sistema mercantilista,
baseava-se, ao contrário, no princípio de que a riqueza de uma nação é a integral da
riqueza de seus cidadãos; de que o indivíduo, guiado pelo interesse próprio, procura
empregar seu trabalho e seu capital de modo mais proveitoso para sua economia e,
portanto, de que o meio mais rápido e mais seguro de enriquecer a nação é o de
deixar aos indivíduos plena liberdade de ação econômica.

A economia liberal, com suas evidentes vantagens com relação ao sistema planificado mercantilista, ter-se-ia firmado como forma de organização da economia a partir do declínio do mercantilismo. Ao Estado, era reservado um papel limitado na economia liberal: "O Estado devia impedir que a liberdade fosse utilizada para matar a liberdade." ${ }^{440}$ Deveria regular, sem diretamente controlar, instrumentos de progresso como o gás de iluminação pública, os transportes (ferroviários), o serviço telegráfico, etc. Economia liberal parece ser, para Gudin, um sistema econômico - uma realidade - à qual corresponderia uma doutrina econômica específica. A economia liberal seria, pois, um período em que vigorara um consenso de princípios liberais, que orientavam o comportamento das economias nacionais,

${ }^{439}$ GUDIN, [1945] 2010, p. 65.

${ }^{440}$ GUDIN, [1945] 2010, p. 65. 
de modo a proporcionar à humanidade o maior nível de conforto material e de liberdade até então visto. O período de economia liberal se encerraria com a Primeira Guerra.

Até 1914 a economia liberal conduziu a humanidade por essa rota, de constante aumento de bem-estar e de elevação do padrão de vida das populações. Dentro dos seus padrões se abordavam e resolviam os novos problemas à medida que eles surgiam. (...). No campo internacional o bastão da liderança cabia à Inglaterra, que velava pelo equilíbrio do sistema. ${ }^{441}$

O período da dita economia liberal corresponderia, grosso modo, ao período da pax britannica, em que vigorou, no mundo ocidental rico, uma relativa estabilidade, ditada pela força da potência hegemônica. Os alicerces dessa ordem mundial britânica são abalados com a Primeira Grande Guerra, que teria desorganizado os sistemas monetários das nações, até atingir a libra esterlina e o dólar. A guerra teria, ainda, precipitado um caos político e econômico na Europa, do qual emergiram "revoluções sociais" na Rússia e, depois, na Itália e Alemanha. Também nesse processo, ocorreria o deslocamento da hegemonia mundial "das mãos experimentadas da Inglaterra, para as mãos vigorosas, mas ainda inexperientes, dos Estados Unidos." $" 42$

A Grande Depressão subsequente seria um resultado dos erros da nova potência hegemônica, ainda inexperiente para reger o mundo. Gudin citava textos do Departamento de Comércio norte-americano, no intuito de confirmar suas teses sobre as crises econômicas do século XX. A crise de 1920-21 teria sido causada, nos EUA e em outros países, pelo movimento inflacionista resultante do abandono dos controles e restrições adotados ao longo da Primeira Guerra. Como causas da Grande Depressão dos anos 1930, citou a política creditícia contracionista adotada pelo Federal Reserve em momento inadequado e a política aduaneira protecionista dos Estados Unidos, que teriam levado a uma escassez no suprimento internacional de dólares, numa hora em que este era por demais necessário. A Inglaterra, potência já não mais hegemônica, mas relevante, não era poupada por Gudin: também teria errado ao firmar uma política deflacionista, a partir de 1925, com o fito de restabelecer a paridade da libra com o dólar. ${ }^{443}$

A conclusão a que chegava Gudin com essa análise retrospectiva era que os diversos desacertos, sobretudo políticos, teriam abalado os alicerces da economia liberal, a qual havia conduzido o mundo por um caminho estável de prosperidade, não fossem essas injunções de caráter extra-econômico.

NÃO CABE ASSIM À ECONOMIA LIBERAL A RESPONSABILIDADE DESSES DESASTRES. Originariamente, a Grande Depressão foi o resultado de um fenômeno político: a

\footnotetext{
${ }^{441}$ GUDIN, [1945] 2010, p. 65.

${ }^{442}$ GUDIN, [1945] 2010, p. 65.

${ }^{443}$ GUDIN, [1945] 2010, p. 67.
} 
guerra mundial de 1914, que abalou profundamente o sistema que a economia liberal havia construído em um século. ${ }^{44}$

Os mecanismos de livre-mercado ofereceriam uma situação de prosperidade, no geral, à humanidade, a menos que houvesse a interveniência de fatores exógenos, que pudessem desequilibrar o sistema. Gudin criticava acerbamente o New Deal americano, que considerava falho em vários pontos e incompatível com a economia liberal e com o respeito ao capital. "De certo, só tinha o New Deal o princípio da execução de obras públicas pelo Estado como um dos meios de contrabalançar a depressão (...) e algumas justas medidas de policiamento contra abusos do capitalismo". ${ }^{445}$ Embora concordasse com as medidas preconizadas por Keynes (e previstas no New Deal) de combate a depressões cíclicas, Gudin no geral considerava o plano de Roosevelt um erro que teria levado os EUA a se recuperarem da crise mais lentamente do que outras nações. A percepção retrospectiva de Gudin é, nesse sentido, um diagnóstico muito mais da conjuntura econômica em si, do que dos determinantes históricos que levaram à situação presente. Para Eugênio Gudin, cumpria explicar por que razões a conjuntura se distanciava daquela trajetória estável, que, ceteris paribus, e economia mundial seguiria, caso prevalecessem os princípios daquilo que denominava "economia liberal".

Essa posição de eximir a economia de qualquer "culpa" relacionada às mazelas da realidade concreta parece herdeira da mudança de ênfase ocorrida na economia, em finais do século XIX, com a revolução marginalista e o triunfo da concepção neoclássica. O enfoque da economia passara a ser os problemas de equilíbrio alocativo e não mais as questões de crescimento, desenvolvimento e reprodução, que haviam preocupado os clássicos. Analisando as relações dessa mudança de ênfase com questões ideológicas, Phyllis Deane ressalta que essa diminuição do raio de alcance da economia permitia aos economistas aderir a uma ideologia individualista, sem comprometer-se politicamente.

\begin{abstract}
Os economistas ingleses, educados numa tradição cujas premissas filosóficas incluíam a doutrina da harmonia social e cuja inclinação política favorecia o livre comércio e um mínimo de intervenção governamental, viam sua ideologia individualista econômica sob crescente pressão nas décadas de 1870 e $1880 .{ }^{446}$
\end{abstract}

Focalizando o caso inglês, Deane destaca que o paradigma neoclássico permitia aos economistas conciliar, de alguma forma, os preceitos liberais com a situação complexa de um capitalismo industrial urbano, em que a indústria britânica enfrentava concorrência internacional cada vez maior e em que o dogma da não-intervenção estatal na economia

\footnotetext{
${ }^{444}$ GUDIN, [1945] 2010, p. 69.

${ }^{445}$ GUDIN, [1945] 2010, p. 69.

${ }^{446}$ DEANE, Phyllis. A evolução das ideias econômicas. Rio de Janeiro: Zahar, 1980. p. 148.
} 
passava a ser revisto. Os economistas não eram mais obrigados a comprometer-se com essas questões, justamente porque o raio de alcance da ciência econômica diminuíra: ela não mais tem a tarefa de fornecer explicações sobre os problemas de reprodução do sistema capitalista a longo prazo.

A emergência do paradigma neoclássico, no Reino Unido e no continente europeu, e suas consequências metodológicas para a economia são questão complexas, cujo aprofundamento está fora do escopo desta dissertação. O que se quer aqui é apenas indicar que Gudin, ao isentar a economia de qualquer responsabilidade pelas crises e instabilidades do século XX, está inserido numa tradição de pensamento segundo a qual à economia caberia um papel muito específico, qual seja, refletir sobre a alocação de recursos escassos. É nesse sentido que se compreende a dissociação radical entre economia e política. Gudin justificava suas posições com argumentos econômicos: a industrialização não deveria ser induzida, porque deslocaria artificialmente fatores produtivos, de modo a prejudicar a eficiência alocativa do sistema. A defesa da não-intervenção estatal era, portanto, "apolítica": o Estado não deveria intervir, porque desviaria a economia do equilíbrio alocativo eficiente. Não cabe à economia elevar um país à posição de grande nação industrializada, como queria Simonsen por meio da planificação. A inserção e o grau de desenvolvimento de um país dependeriam de sua dotação de fatores e da possibilidade de alocá-los com grau elevado de produtividade. "São esses índices de produtividade técnica que respondem pela prosperidade dos Estados Unidos e pelo alto padrão de vida de seu povo. Isso e não o seu protecionismo aduaneiro". ${ }^{447}$

Gudin não discutia com profundidade os processos históricos, pois tais questões não estavam em seu escopo. Para Gilberto Maringoni, inexiste, em Gudin, "a percepção dos interesses políticos e econômicos em jogo e as alternativas colocadas no tabuleiro. Sem isso, o que se tem é uma descrição rasa, sem nexos de causalidade entre sujeitos e processos." ${ }^{448}$ De fato, Gudin parecia não ver conexões entre o econômico e as outras esferas da vida social. No geral, era verdadeiro para Gudin que "se a equação falha, o problema estaria fora da alçada econômica." $" 449$. A entrada de Gudin no debate sobre as causas dos problemas brasileiros se dava pela via da economia em sentido estrito, mais especialmente da tradição neoclássica que estabelecera com a revolução marginalista. É uma entrada distinta a de Roberto Simonsen.

No primeiro texto da controvérsia sobre o planejamento, Simonsen constatava a situação de atraso da economia brasileira, sobretudo pelo fato de a renda nacional ser insuficiente para

\footnotetext{
${ }^{447}$ GUDIN, [1945] 2010, p. 116.

${ }^{448}$ MARINGONI, Gilberto. "Liberalismo radical”. IN: TEIXEIRA, Aloísio; MARINGONI, Gilberto; e GENTIL, Denise Lobato. Desenvolvimento: o debate pioneiro de 1944-1945. Brasília: IPEA, 2010. p. 76.

${ }^{449}$ MARINGONI, 2010, p. 78.
} 
proporcionar aos cidadãos brasileiros um nível de vida aceitável. Destacava também a superioridade das nações industriais sobre as nações de "economia vegetal" e reconhecia a especificidade dos dois tipos de países. Ao comentar o relatório da Missão Cooke ${ }^{450}$, destacou o fato de terem os países industriais se desenvolvido com base em reservas de carvão mineral e minério de ferro, próximas umas das outras e dos grandes centros urbanos. Não sendo essa a situação brasileira, estava claro que o desenvolvimento do Brasil teria de se dar por meio de processos distintos dos que prevaleceram no século XIX. ${ }^{451}$

Em sua réplica a Gudin, Simonsen dá mais elementos de seu diagnóstico sobre o atraso brasileiro. Para o autor, o país não teria aproveitado os frutos do acelerado enriquecimento pelo qual passaram as nações industrializadas e em vias de industrialização durante o século XIX.

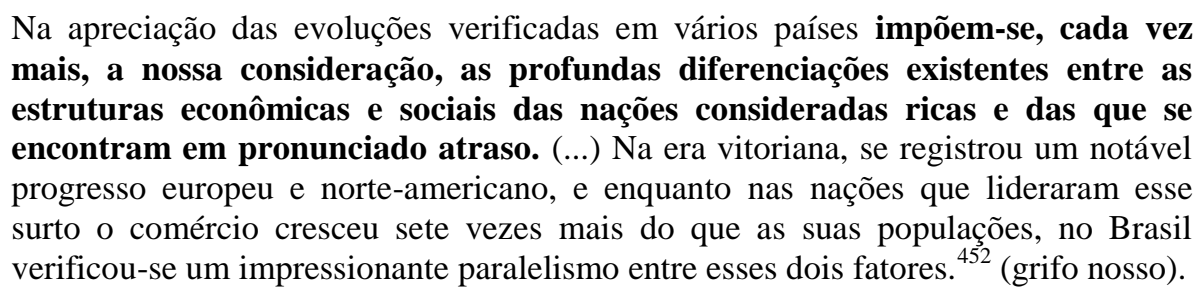

Simonsen discutia a situação da economia brasileira em termos bem diferentes dos adotados por Gudin. Na era vitoriana, em que teriam vigorado os princípios da economia liberal, Simonsen fez a qualificação de que o progresso, que de fato existiu em parte do globo, não se distribuiu de forma uniforme por todas as nações. Sobre esse período da economia liberal, afirmava que "Se a escola liberal fixou, pela análise dos fatos sociais e econômicos, uma série de leis que predominavam no grande surto progressista verificado nas nações líderes do século passado, admite o relator [Gudin] a cristalização definitiva dessas leis". 453

As leis da economia liberal, que ceteris paribus conduziriam a humanidade pelo caminho da prosperidade, eram questionadas de um ponto de vista histórico. A ideia fundamental é: enquanto algumas nações trilhavam um caminho, outras seguiam outra evolução, muito distinta, de forma que a suposta economia liberal associada à prosperidade existiu apenas para uma parte do mundo, num período específico. A ênfase do diagnóstico de Simonsen está na particularidade histórica do desenvolvimento periférico e na situação desfavorável em que os

\footnotetext{
${ }^{450}$ A Missão Cooke foi uma iniciativa de cooperação econômica entre Brasil e Estados Unidos, durante a Segunda Guerra (1942-1943). O objetivo da Missão era fazer um levantamento dos recursos disponíveis no Brasil, que pudessem ser aproveitados na conjuntura do conflito mundial. A Missão Cooke está associada aos esforços brasileiros para obter financiamento para projetos de infraestrutura, como a usina siderúrgica de Volta Redonda.

${ }^{451}$ SIMONSEN, [1944] 2010, pp. 39-42.

${ }^{452}$ SIMONSEN, Roberto. "O planejamento da economia brasileira - Réplica ao Sr. Eugênio Gudin”. [1945]. IN: SIMONSEN, Roberto, GUDIN, Eugênio e VON DOELLINGER, Carlos. A controvérsia do planejamento na economia brasileira. $3^{\mathrm{a}}$ edição. Brasília: IPEA, 2010. p. 132.

${ }^{453}$ SIMONSEN, [1945] 2010, p. 154.
} 
países periféricos se encontravam, devido justamente à função desempenhada por eles na evolução do capitalismo internacional. Simonsen analisara, em $H E B$, o estabelecimento do capitalismo europeu e a formação dos "grandes países agrícolas" a ele articulados. Ressaltara como fatores importantes para o evolver do capitalismo europeu, nos séculos XVIII e XIX, a intensificação do comércio e o afluxo de metais preciosos da América do Sul e, posteriormente, das minas norte-americanas e africanas.

Toda essa riqueza metálica deu ainda exagerado impulso à evolução capitalista, ao grande surto industrial da Europa e da Norte-América e a uma acentuada diferenciação e divisão do trabalho, com a consequente criação dos grandes países agrícolas. É fruto também desse sistema econômico, a adoção, pelos grandes Estados, de definidas políticas coloniais, cuja interferência sofremos no passado e que ainda hoje atuam de modo inequívoco em nossa evolução, devido, principalmente, à natureza tropical da maioria de nossas produções. ${ }^{454}$ (grifo nosso).

Era clara a relação entre a situação da economia brasileira e o seu passado colonial, relacionado a uma inserção na divisão internacional do trabalho determinada pela evolução do capitalismo europeu, em sua fase de formação e em sua fase industrial. Tal relação fora feita por Simonsen nas partes iniciais da História econômica do Brasil: o Brasil teria surgido como colônia engatada ao exterior, fruto da expansão mercantil portuguesa. Essa interpretação da situação dos países agrícolas está muito próxima das ideias apresentadas por Prokopovich, em seu estudo sobre a industrialização dos países atrasados. Analisando com detalhes os dados referentes ao comércio mundial de trigo, do século XVIII à Primeira Guerra, o autor demonstra haver um claro deslocamento da produção de trigo das nações que se industrializam ao longo desse período para os países que não se industrializam por completo.

\footnotetext{
Segundo esses dados, o processo de europeização da agricultura dos países atrasados e coloniais não se desenvolvia mais de modo autônomo; esses países não criavam novas formas econômicas, partindo das raízes nacionais. Do mesmo modo, eles não adotavam as formas econômicas novas dos países industriais avançados. Pelo contrário, foram estes últimos que, graças ao comércio, introduziram-se nos países atrasados e coloniais. As forças dinâmicas provinham dos países avançados e economicamente poderosos, e não dos países atrasados e das fracas forças produtivas de suas economias nacionais. ${ }^{455}$ (grifo nosso)
}

Prokopovich percebia a dependência dos países não industrializados e o caráter reflexo de suas economias. Os países "atrasados e coloniais" se desenvolviam na órbita do capitalismo europeu, sem possuir forças dinâmicas internas. Os países do chamado Novo Mundo se desenvolveram de forma articulada ao capitalismo europeu, cumprindo um papel específico na divisão internacional do trabalho.

Os territórios coloniais com uma população indígena dispersa - Estados Unidos,

Canadá, Brasil, Argentina, Austrália e Nova Zelândia - devem o seu

\footnotetext{
${ }^{454}$ HEB, p. 31.

${ }^{455}$ PROKOPOVICH, Sergei Nikolaievich. L'industrialisation des pays agricoles et la structure de l'économie mondiale après la guerre. [1943]. Neuchâtel: Éditions de la Baconnière, 1945. p. 37.
} 
desenvolvimento cultural e econômico aos imigrantes europeus, aos capitais europeus e ao comércio europeu. Os países atrasados e coloniais eram necessários aos países industriais da Europa ocidental enquanto fornecedores das matériasprimas necessárias às suas indústrias e dos produtos alimentares, e igualmente como mercados para o escoamento de seus produtos manufaturados. Se esses países não tivessem existido, o desenvolvimento das forças produtivas da Europa ocidental teria sido muito mais lento no século XIX. ${ }^{456}$ (grifo nosso).

Assim como Simonsen, Prokopovich incluía em sua análise o papel específico dos países atrasados na divisão internacional do trabalho: fornecimento de matérias-primas coloniais e mercado de escoamento da produção. Simonsen destacara ainda o fornecimento de metais preciosos, que teria contribuído para fomentar o surto industrial europeu. Tratava-se, para os dois autores, de um papel necessário e funcional à evolução do capitalismo e, sobretudo, de um papel que não é determinado endogenamente pelas regiões atrasadas e nem fruto de alguma "vocação natural" - é uma função imposta pelos imperativos da dinâmica da expansão da economia europeia.

As abordagens de Simonsen e Prokopovich parecem convergir também no que tange à crítica à ideia de que o comportamento da economia mundial seria regido por leis, “cristalizadas" e imutáveis, as quais conduziriam a humanidade por uma rota de prosperidade, caso pudessem operar sem distúrbios extraeconômicos. Simonsen criticava o fato de Gudin tomar como universais as leis da economia liberal, que regeriam o comportamento do homo economicus e fez uma exortação:

\begin{abstract}
Para S.S $S^{\text {a }}$ Eugênio Gudin], o homo economicus da escola individualista é o que deve imperar nos processos sociais e econômicos de hoje. Não compreendeu que, pela contínua renovação da humanidade, pela transformação profunda por que passaram os povos, com os crescimentos demográficos, com os processos da ciência e da técnica e sob a influência dos ambientes geográficos, quem agora quiser compreender a possibilidade da existência de um desenvolvimento pacífico mundial, tem que substituir o egoísta homo economicus pelo moderno "homem social" que antepõe aos seus próprios os interesses da coletividade. ${ }^{457}$ (grifo nosso).
\end{abstract}

No intuito de delinear os fatores a influenciar a industrialização ou o atraso de países e regiões, Prokopovich fez um apanhado de diversos autores que abordaram o tema, dentre os quais se destacam Petty, Ricardo, Steuart e Thünen. ${ }^{458}$ Uma diferenciação importante feita pelo autor se referia aos economistas do século XVII e XVIII, que viam nos fatores geográficos ou naturais a principal causa para a distribuição da atividade econômica entre países, e aqueles que, a partir do século XIX, começaram a ver fatores histórico-culturais - a acumulação de capital e produtividade - como principais razões a diferenciar os países do ponto de vista de sua evolução econômica. Prokopovich ressaltava que os economistas mais

\footnotetext{
${ }^{456}$ PROKOPOVICH, [1943] 1945, p. 38.

${ }^{457}$ SIMONSEN, [1945] 2010, p. 154.

${ }^{458}$ PROKOPOVICH, 1943 [1945], pp. 11-19.
} 
antigos observavam a realidade de seu tempo, em que, de fato, o fator natural parecia desempenhar papel preponderante. Já autores como Ricardo, vivendo em plena revolução industrial, não poderiam ignorar os efeitos, sobre a economia da Grã-Bretanha, de fatores como a acumulação de capital e a alta produtividade do trabalho. Prokopovich concluía pela primazia dos fatores históricos na determinação da ação econômica do homem, não podendo esta ser determinada por condicionantes naturais ou inatos.

(...) a base da economia nacional não é nem o meio geográfico, nem o homo economicus, com seus dados e aspirações econômicas inatas, mas o processo do desenvolvimento histórico, da cultura intelectual e material do homem. ${ }^{459}$

Há, como foi mostrado, alguma convergência nos argumentos de Simonsen e Prokopovich, que eram contemporâneos um do outro. O pano de fundo geral dessa convergência é o contexto histórico do final da Segunda Guerra, em que havia uma preocupação em readaptar as economias, atrasadas ou não, submetidas com graus variáveis à planificação de guerra, a uma situação de paz. A abordagem de Prokopovich era mais sofisticada, na medida em que discutia a questão do homo economicus em perspectiva comparativa, situando marcos, na evolução do pensamento econômico, que apontavam na direção de uma percepção, por parte dos economistas, da diferenciação entre os países e regiões como resultado de um processo histórico. A Roberto Simonsen interessava, acima de tudo, contestar o posicionamento de Eugênio Gudin, que via a história econômica como movimento de leis "cristalizadas". Em que pesem os pontos de vista distintos, parece haver uma afinidade considerável na tônica das discussões realizadas por Simonsen e por Prokopovich.

Um denominador comum entre esses dois autores parece ser a busca de uma explicação para o atraso econômico dos países não industrializados nos processos históricos específicos que condicionaram suas evoluções - e não em vocações naturais ou leis inatas do comportamento econômico. Esse tipo de abordagem, presente nos dois autores, que privilegia as especificidades históricas e que, portanto, permite uma "transgressão" das leis econômicas que supostamente governariam o desenvolvimento é condição para que se possa solidificar um discurso industrializante e favorável ao planejamento econômico. Ora, se as economias movem-se inexoravelmente numa determinada direção e essa direção é o caminho da prosperidade, não há margem para a industrialização planejada. Simonsen estava interessado na industrialização do Brasil, induzida pelo Estado e realizada com base na iniciativa privada. Prokopovich estava interessado, acima de tudo, no desenvolvimento soviético, na

\footnotetext{
${ }^{459}$ PROKOPOVICH, [1943] 1945, p. 19.
} 
emancipação da Rússia soviética com relação às potências europeias. ${ }^{460} \mathrm{Em}$ ambos os casos, as intenções dos autores pressupõem que o rumo dos acontecimentos possa seguir um curso diferente daquela direção inexorável dada pelas leis da economia tradicional.

As ideias de Simonsen e Prokopovich - e também as de Manoilescu e Woytinsky podem ser vistas, portanto, como partes de um ambiente de ideias econômicas, em que a teoria das vantagens comparativas era questionada - e a história ganhava relevância sobre fatores exclusivamente econômicos ou até naturais, como a questão climática, que fora cara a Friedrich List. Essas ideias seriam importantes para legitimar propostas - teóricas e práticas ligadas ao desenvolvimento dos países periféricos. Se a situação de atraso é produto de uma evolução histórica específica - e não de uma vocação inata -, a situação pode ser modificada, se o curso dos acontecimentos for alterado por políticas concretas. A tradição históricoestruturalista, que tem em Celso Furtado seu principal expoente brasileiro, foi certamente influenciada por essa abordagem do problema do atraso adotada por Simonsen, inserido nesse quadro internacional em que circulavam abordagens que valorizavam a história econômica e questionavam as vantagens ilimitadas do comércio livre.

Se a ideia do atraso como fenômeno histórico é relevante por dar sustentação a um tipo de proposta de política econômica que se solidificaria com a economia do desenvolvimento, cabe examinar as propostas de Simonsen para a economia brasileira, apresentadas no debate com Gudin. Como foi apontado, tais proposições ligam-se à defesa da industrialização e do planejamento econômico. Na controvérsia, Simonsen procurou se defender de duas críticas repisadas por Gudin. A primeira era a associação entre planejamento e autoritarismo e a segunda, a falta de argumentos econômicos teóricos que justificassem a adoção da planificação como estratégia de desenvolvimento. É com o propósito de rebater essas críticas que Simonsen recorreu a Carl Landauer. A referência a Landauer é especialmente interessante por ter sido uma obra com a qual o autor teve contato no decorrer de seu debate com Gudin. Ademais, o livro Theory of national economic planning encontra-se na Coleção Roberto Simonsen, e contém anotações à margem e sublinhados que muito provavelmente foram feitos pelo próprio Simonsen. Alguns desses trechos destacados encontram-se no ANEXO II do trabalho.

Simonsen via o plano como técnica, como meio de se chegar a um fim específico: a industrialização integrada. "O planejamento representa uma coordenação de esforços para um determinado fim." 461 No primeiro texto do debate, o autor analisou dados do Ministério do Trabalho sobre a renda nacional, que considerava exígua, e referiu-se aos problemas

\footnotetext{
${ }^{460}$ KOJIMA, 2009, pp. 131-135.

${ }^{461}$ SIMONSEN, [1945] 2010, p. 134.
} 
decorrentes do esforço de guerra, no Brasil e em outras nações. Os dados sobre a renda nacional são alvo de vigorosa crítica de Gudin, que apontou imprecisões graves de mensuração. Simonsen, contudo, baseou-se nesses dados e em observações mais gerais para chegar à seguinte conclusão:

\begin{abstract}
Impõe-se, assim, a planificação da economia brasileira em moldes capazes de proporcionar os meios adequados para satisfazer as necessidades essenciais de nossas populações e prover o país de uma estruturação econômica e social, forte e estável, fornecendo à nação os recursos indispensáveis a sua segurança e a sua colocação em lugar condigno na esfera internacional. ${ }^{462}$
\end{abstract}

Gudin citou o trecho acima, em sua resposta a Simonsen, para criticar vigorosamente a planificação, que considerava resultante de uma sucessão de desacertos, sobretudo de ordem política. Esse caos em que se atirara o mundo em consequência das guerras do século XX teria criado, para Gudin, um ambiente propício à mistificação do plano, no sentido de que este era apresentado como a solução de todos os problemas econômicos. ${ }^{463}$ O próprio emprego da palavra "plano" estaria revestido de uma mistificação, pois ao Estado liberal caberiam certas atividades, que não necessariamente se deveria chamar de "plano", palavra carregada de conotação antidemocrática. É dessa crítica que Simonsen procurava se defender, ao insistir na atualidade e necessidade do plano, para superar os entraves da realidade presente.

\title{
É um erro supor que o conceito de planejamento se prenda a escolas políticas e econômicas antidemocráticas. (...) O Estado liberal vem planejando, de há muito e progressivamente. Se a expressão é nova, a realidade é velha. O planejamento apresenta-se, hoje, como técnica de maior vulto, porque os problemas se tornaram muito complexos e enormes têm sido os progressos verificados nas ciências econômicas, sociais e na tecnologia em geral. ${ }^{464}$ (grifo nosso).
}

O planejamento era apresentado como técnica, não necessariamente ligada a um tipo de governo, a qual poderia ser usada para alterar a realidade econômica de um país. Para Simonsen, o plano teria um caráter nacionalista: atuaria no interesse da "sociedade brasileira", não havendo filiação a uma tendência específica do espectro político. Tratava-se, acima de tudo, de uma técnica vista como atual, mais adequada à resolução aos problemas presentes do que os princípios da economia liberal, da forma colocada por Gudin. "O planejamento econômico é uma técnica e não uma forma de governo". ${ }^{465}$ Essa ideia estava presente no livro de Landauer - e foi destacada e anotada por Simonsen no seguinte trecho:

O planejamento econômico, portanto, é uma técnica que toda política econômica pode usar, e quase sempre tem de usar, para atingir seu objetivo com algum grau de certeza. Sendo necessário distinguir entre intervenção do governo e planejamento econômico, também é verdadeiro que toda intervenção governamental,

\footnotetext{
${ }^{462}$ SIMONSEN, [1944] 2010, p. 44.

${ }^{463}$ GUDIN, [1945] 2010, p. 55.

${ }^{464}$ SIMONSEN, [1945] 2010, p. 134.

${ }^{465}$ SIMONSEN, [1945] 2010, p. 135.
} 
independentemente de seus objetivos, é tecnicamente inferior se não utiliza o planejamento. ${ }^{466}$

Ao reafirmar, por meio das ideias de Landauer, que o planejamento era uma "técnica atual" que poderia ser usada por qualquer governo, Simonsen rebatia a acusação de Gudin, que associava a planificação ao socialismo, ao mesmo tempo em que lhe atribuía um caráter de avanço com relação às estratégias de política habituais: se havia intervenção governamental, melhor seria planejar essa intervenção. “[O planejamento $]$ ainda não foi compreendido pelos 'saudosistas' que só querem enxergar os 'encantos' do século passado que, aliás, só puderam ser apreciados em algumas privilegiadas nações". ${ }^{467}$ Mesmo nessas nações ricas, argumentava Simonsen, a prosperidade proporcionada pela economia liberal só pôde ser usufruída por pequena parte de suas populações.

O caráter progressista que o plano assumia para Simonsen, buscando a superação do atraso econômico brasileiro, não eliminava traços conservadores de sua proposta.

[O planejamento econômico] cria um ambiente de segurança de tal ordem que facilita o melhor e mais eficiente aproveitamento da iniciativa privada, que está intimamente ligada ao conceito de propriedade. Nos países em que existe o sufrágio universal e onde a maioria dos votantes não é proprietária, a propriedade privada se manterá em sua plenitude enquanto essa maioria estiver convencida de que o exercício desse direito representa o verdadeiro interesse da sociedade em conjunto. $^{468}$ (grifo nosso).

O planejamento deveria, então, promover a riqueza nacional, mantendo a lei e a ordem, necessárias ao funcionamento da iniciativa individual e à manutenção da propriedade privada como instituto inquestionável. Não se deve esquecer que o contexto de final da guerra levava à reflexão sobre a estabilidade social. A URSS emergia como potência mundial e o socialismo, como sistema econômico, estava na ordem do dia. Um industrial como Roberto Simonsen certamente se via chamado a posicionar-se sobre essa questão. Seu raciocínio parece ser simples: se houver garantias mínimas de direitos sociais e um padrão de vida aceitável, as instabilidades sociais poderão ser evitadas.

Como se procurou mostrar, Simonsen entrou no debate sobre planejamento econômico no Brasil a partir de uma perspectiva histórica. Estudou a história da economia brasileira, a partir de uma perspectiva nacionalista e industrialista, e propôs o planejamento como técnica capaz de mudar os rumos dessa evolução histórica. Não apresentou, contudo, nem no primeiro texto da controvérsia do planejamento, nem em textos anteriores, uma teoria do planejamento, dando margem para duras críticas por parte de Gudin. Se buscara elementos teóricos importantes sobre a teoria do comércio internacional, em autores estrangeiros como List,

\footnotetext{
${ }^{466}$ LANDAUER, 1944, p. 118. Ver ANEXO II.

${ }^{467}$ SIMONSEN, [1945] 2010, p. 135.

${ }^{468}$ SIMONSEN, [1945] 2010, p. 135.
} 
Manoilescu, Woytinsky e Wagner, Simonsen não fizera o mesmo com o planejamento. Não havia uma argumentação rigorosa de que o planejamento poderia ser efetivo, do ponto de vista da teoria econômica. Simonsen estava ciente dessa necessidade e citou, em sua resposta a Gudin, o livro de Carl Landauer.

Após a apresentação do meu parecer ao Conselho Nacional de Política Industrial e Comercial, veio-me às mãos a notável obra do professor Carl Landauer, da Universidade da Califórnia, sobre a "Teoria do Planejamento Econômico Nacional". Nesse trabalho, aquele erudito professor de economia aponta a estruturação de um planejamento econômico total nos países progressistas, como o meio mais eficaz de extirpar as depressões e crises cíclicas que lhes perturbam a vida. $^{469}$ (grifo nosso)

Era uma tentativa de legitimar o planejamento, não só pela via de sua necessidade histórica, mas, também, pela via da teoria econômica. Vale lembrar que Gudin criticara os dados e conclusões apresentados por Simonsen do ponto de vista econômico, apontando inconsistências e lacunas em suas elaborações. Com a referência a Landauer, Simonsen tentava incluir, em sua réplica, elementos de uma discussão especificamente econômica. A principal justificativa apresentada por Landauer para a planificação era a existência do ciclo econômico, em que se alternam fases de depressão e ascensão. Segundo Landauer, haveria muitas diferenças entre a "economia de mercado perfeito" que se ajusta automaticamente e a economia real. O desemprego seria uma dessas muitas diferenças. Landauer divide as teorias do ciclo em dois grandes grupos: a "teoria do subconsumo" (underconsumption theory) e a "teoria da sobreinversão" (overinvestment theory). Conforme a hipótese do subconsumo, que considera inválida a lei de Say, as depressões teriam como causa uma incompatibilidade entre os investimentos feitos no período de auge e o poder de compra gerado por essas inversões. Consoante a teoria da sobreinversão, para a qual vale a lei de Say, haveria uma divergência crescente entre os projetos de investimento formulados pelos empresários no período ascensional e a disponibilidade de recursos, resultando em periódicas depressões. Grosso modo, o primeiro grupo atribui a causa das flutuações ao lado da demanda e o segundo, ao lado da oferta. ${ }^{470}$

Landauer destacava o fato de que haveria, na economia real, um desconhecimento, por parte dos agentes, dos resultados de suas ações. Os empresários não fazem seus projetos de investimento com base nos projetos de seus concorrentes e não sabem como serão as condições de mercado no futuro. Só se conhecerão os resultados da ação econômica algum tempo depois de executada. O sistema de preços não consegue coordenar perfeitamente as atividades econômicas individuais, já que reflete somente as condições atuais do mercado,

\footnotetext{
${ }^{469}$ SIMONSEN, [1945] 2010, p. 135.

${ }^{470}$ LANDAUER, 1944, p. 7.
} 
incorporando fatores acidentais como a especulação. Em ambos os casos teóricos descritos acima, o ciclo poderia ter sido atenuado se houvesse sinais do comportamento dos preços futuros. No caso do subconsumo, se houvesse meios de saber os resultados das operações presentes, a expansão certamente não chegaria a um ponto perigoso, pois os empresários não desejam criar capacidade produtiva que não tenha emprego. Em se tratando das teorias da sobreinversão, o colapso poderia ser evitado se uma previsão do incremento de preços tivesse prevenido os empresários da iminente deficiência de recursos. A planificação funcionaria, pois, como meio de oferecer aos agentes sinais mais estáveis sobre a economia.

\begin{abstract}
Cabe conceber dois meios para fazer desaparecer a causa que as duas escolas, cada uma de seu ponto de vista, consideram como responsável pelas flutuações econômicas. Deve-se intervir no mecanismo do sistema de preços de modo que os preços presentes reflitam, com uma amplitude suficiente, a situação futura de oferta e demanda; ou se devem calcular antecipadamente os efeitos dos compromissos que os empresários projetam aceitar, e induzi-los a não levar em conta os preços atuais, na medida em que estes os levam a aceitar compromissos que não podem cumprir. ${ }^{471}$ (grifo nosso).
\end{abstract}

O planejamento tem, com Landauer, uma justificativa econômica teórica, baseada na hipótese de que o sistema de preços não é um bom guia para o empresário elaborar seus projetos, que só se concretizarão no futuro, o que leva à ocorrência de depressões. Essa ideia seria compatível, segundo o próprio autor, com as formulações de Keynes. Landauer era da opinião que a elaboração de Keynes sobre o ciclo é, na verdade, compatível com as duas abordagens teóricas mencionadas acima: seria um marco, dentro do qual cabem diferentes teorias do ciclo. A causa das depressões seria, para Keynes, a queda súbita da eficiência marginal do capital, mas o motivo dessa redução dos retornos esperados do capital permanece em aberto, havendo espaço para várias explicações. ${ }^{472}$ Landauer apresenta uma definição de planificação, à qual Simonsen alude em sua réplica a Gudin. ${ }^{473}$

\begin{abstract}
A planificação pode ser definida como a orientação das atividades econômicas por um organismo da comunidade, valendo-se de um projeto que descreve, em termos qualitativos e quantitativos, os processos de produção que devem ser levados a cabo durante um período determinado do futuro. Para alcançar o propósito principal da planificação, os processos devem ser escolhidos e projetados de modo que assegurem o emprego total dos recursos disponíveis e evitem demandas contraditórias, tornando possível um ritmo estável de progresso. ${ }^{474}$ (grifo nosso).
\end{abstract}

Se os projetos a serem levados a cabo são planificados, elimina-se a causa fundamental do ciclo - e das depressões - que era a impossibilidade de se antecipar as consequências das ações econômicas. Com o plano, o futuro se tornava previsível, não havendo os descompassos

\footnotetext{
${ }^{471}$ LANDAUER, 1944, p. 8.

${ }^{472}$ LANDAUER, 1944, p. 9.

${ }^{473}$ SIMONSEN, [1945] 2010, p. 135.

${ }^{474}$ LANDAUER, 1944, p. 13. Este trecho foi sublinhado por Simonsen no livro de Landauer. Ver ANEXO II.
} 
entre oferta e demanda ou entre inversões e disponibilidade de recursos, que caracterizavam as depressões cíclicas. Discutida a possibilidade teórica de o planejamento eliminar o ciclo econômico, Landauer passava a considerações de caráter técnico e político-ideológico relativas à elaboração e execução do plano, às quais Simonsen se refere brevemente: "[Landauer] aconselha a manutenção da produção em mãos da iniciativa privada e, para a execução do planejamento, acredita mais nos meios suasórios do que nos compulsórios."475

Landauer dedicou um capítulo de seu livro à discussão sobre planificação e democracia. $\mathrm{O}$ argumento geral era que a planificação, numa economia de mercado, deve atuar para proporcionar aos consumidores os melhores meios de satisfazerem seus desejos. Não é, portanto, para favorecer os donos de fábricas que deve ser implementada uma política de incentivo a determinado setor industrial, mas em benefício da coletividade. Na mesma linha de Simonsen, Landauer via na planificação econômica uma maneira de manter a ordem democrática. Landauer, todavia, argumenta não tanto do ponto de vista da garantia da propriedade privada, mas da segurança econômica do cidadão. "Entre os grandes aportes positivos feitos pela planificação para fortalecer o Estado democrático, a primeira é a seguridade econômica, que diminuirá a tentação de aceitar a ditadura e, ao mesmo tempo, ajudará a produzir o tipo de mente sã que é fundamental para o funcionamento da democracia". 476

A democracia e os regimes de governo ocupam lugar central na obra de Landauer, de forma que o planejamento econômico deve ser usado como meio de evitar as ditaduras e os totalitarismos. Nesse ponto, há uma convergência com Simonsen, ainda que este argumente mais do ponto de vista do capital. Ambos os autores parecem estar preocupados com a situação das economias no pós-guerra. Viam a necessidade de assegurar melhores condições de vida aos cidadãos, dentro da ordem democrática vigente, ou melhor, para evitar uma quebra traumática da institucionalidade, nos moldes daquela que o mundo estava vivendo com a Segunda Guerra. Ambos convergem no ponto de que o desenvolvimento - ou o desenvolvimento planejado, para Landauer - afastaria as possibilidades de ruptura, tanto fascista quanto revolucionária, da institucionalidade democrática.

Landauer não tinha uma elaboração que se referisse especificamente aos países atrasados: procurava legitimar o planejamento como categoria geral, como forma de estabilizar economias por natureza instáveis. Sua preocupação era mais geral do que a de Prokopovich, por exemplo, que chegava a focalizar os países agrícolas em especial. Mas a preocupação de fundo, que parece orientar Roberto Simonsen e esses dois autores estrangeiros, é a ideia

\footnotetext{
475 SIMONSEN, [1945] 2010, p. 135.

${ }^{476}$ LANDAUER, 1944, pp. 180-181.
} 
progressista de que algo deve ser feito, no sentido da melhoria das condições materiais das nações, para que não se repitam as tragédias vividas pelo mundo ocidental no período que Hobsbawm chama de "era da catástrofe". Nesse sentido, as elaborações de Simonsen, no âmbito da discussão de 1944-45, estavam em sintonia com essa discussão internacional sobre a situação econômica dos países no pós-guerra e como se deveria agir sobre ela. O campo da economia do desenvolvimento, que se firmaria como vertente teórica importante da ciência econômica no século XX, certamente estaria imbuído dessas questões que Simonsen, em sintonia com Manoilescu, Woytinsky, Prokopovich, Landauer e outros autores internacionais, discutiu no Brasil, nesse momento crítico do final da Segunda Guerra.

\subsection{O pós-guerra e algumas questões latino-americanas}

Ainda durante a Segunda Guerra - e anteriormente à controvérsia do planejamento Simonsen se pronunciou sobre as questões da organização econômica mundial no pós-guerra. Sua manifestação sobre este tema, ainda durante o conflito mundial, é o texto Alguns aspectos da Política Econômica mais conveniente ao Brasil no período de após-guerra, uma conferência pronunciada em 1943 e publicada pela FIESP. Em um texto posterior, publicado já depois do debate com Gudin, 1947, apareceu a perspectiva latino-americana: O Plano Marshall e suas prováveis repercussões na América Latina, um relatório apresentado na XXVI Reunião Plenária da Comissão Executiva do Conselho Interamericano de Comércio e Produção. Por último, o texto "Direito Internacional Social", de 1948, uma brochura publicada no momento em que o Brasil sofria as consequências do reordenamento mundial pós-Segunda Guerra. Neste último texto, há a ideia de deterioração dos termos de troca, apresentada com certa clareza.

De forma geral, esses textos que tratam do período pós-guerra apresentam alguns traços que merecem ser destacados. Mais do que nos pareceres da controvérsia do planejamento, há nesses escritos a ideia do "mundo periférico": não se tratava mais somente do Brasil, embora o Brasil fosse o centro das preocupações de Simonsen. Em outras palavras, havia sinais da busca de uma identidade entre os países não desenvolvidos. Conceitos como "subdesenvolvimento", "periferia do capitalismo" ou "países dependentes" estão, como veremos, ausentes dos textos de Simonsen, motivo pelo qual é necessário qualificar conclusões de estudiosos do pensamento de Simonsen que o veem como claro "antecipador" do pensamento ligado à CEPAL ou da economia do desenvolvimento em sentido mais amplo. ${ }^{477}$ Seria mais preciso afirmar que Simonsen certamente contribuiu para a produção e

${ }^{477}$ Ver CEPÊDA, 2003, e FANGANIELLO, 1970. 
difusão, no Brasil, de ideias econômicas que seriam fundamentais para o estabelecimento das vertentes teóricas ligadas à economia do desenvolvimento. A apropriação feita, no texto de 1943, das ideias de Colin Clark, economista inglês considerado um dos "pioneiros do desenvolvimento", é um exemplo desse tipo de difusão de ideias. ${ }^{478}$

$\mathrm{O}$ argumento de Alguns aspectos referia-se a um aprofundamento das diferenças internacionais com a Segunda Guerra Mundial: se beneficiou as nações aliadas, como um todo, Simonsen afirma, certamente algumas nações foram mais beneficiadas do que outras sobretudo os Estados Unidos, que tiveram sua capacidade de produção "agigantada no final da guerra". ${ }^{479}$ Esse crescimento da capacidade produtiva teria ocorrido, de acordo com Simonsen, em ramos estratégicos como a produção de ferro, aço e artigos sintéticos. O Brasil, por seu turno, teria contribuído com matérias-primas estratégicas e gêneros alimentícios, permanecendo seu aparelhamento fabril e ferroviário em profundo desgaste. Isso leva Simonsen a concluir que "No terreno da relatividade nos empobrecemos, de fato, comparativamente com os índices de enriquecimento das potências democráticas" ${ }^{480}$. Dessa forma, as políticas econômicas a serem seguidas, no após-guerra, pelos países ricos e pobres deveriam ser distintas. No caso dos primeiros, o objetivo deveria ser manter a renda nacional elevada, evitar o desemprego, melhorar a distribuição de renda. No Brasil e nas demais nações latino-americanas, os problemas seriam mais fundamentais: como elevar a renda nacional a níveis correspondentes ao "estágio de civilização" aspirado pelo Brasil e garantir a cada habitante um conjunto de recursos capaz de lhe proporcionar uma existência digna. ${ }^{481}$ Simonsen reivindicava, então, a cooperação das nações aliadas, que seriam vitoriosas na guerra, para atingir este objetivo da elevação da renda nacional.

A ideia da elevação da produção nacional, acima da sua distribuição, como principal meta de política econômica a ser perseguida, já fora mencionada em textos anteriores, como o discurso de 1935: o que há de diferente no texto de 1943 é a associação desse objetivo com os esboços de uma "teoria" da divisão internacional do trabalho. "De um modo geral, não é possível a um grande país, com elevada população, obter alto rendimento nacional mediante a exploração das indústrias extrativas e de cultivo da terra". ${ }^{482}$ Essa ideia era justificada com base no argumento de que a remuneração paga a cada indivíduo por seu trabalho é função da

\footnotetext{
478 ARNDT, H. W. "Clark, Colin Grant (1905-1989)". IN: The New Palgrave Dictionary of Economics. Online Edition. Palgrave Macmillan, 2009.

${ }^{479}$ SIMONSEN, Roberto. Alguns aspectos da Política Econômica mais conveniente ao Brasil no período de após-guerra. São Paulo: FIESP, 1943. p. 4. Na capa da brochura, lê-se: "Conferência pronunciada a 8-X-1943, no Auditório dos Serviços Hollerith, no Rio de Janeiro, e mandada imprimir pela Federação das Indústrias do Estado de São Paulo, de acordo com resolução de sua Diretoria.

${ }^{480}$ SIMONSEN, 1943, p. 6.

${ }^{481}$ SIMONSEN, 1943, p. 6.

${ }^{482}$ SIMONSEN, 1943, p. 7.
} 
"soma de conhecimentos, de invenções técnicas e de organizações econômicas de que ele se utiliza no exercício de sua atividade, como dos riscos de que participa". ${ }^{483}$

Sendo assim, estabelecia-se uma hierarquia de remunerações e riquezas, dentro de um mesmo país e entre nações. Nos locais onde a atividade é mais concentrada em trabalhos primários, a riqueza é menor e o padrão de vida, inferior. Nas áreas onde o progresso evoluiu, "vulgarizando na população a utilização de todos os inventos, progressos e organizações criados pelo engenho humano" ${ }^{484}$, elevam-se a riqueza e o padrão de vida das pessoas. Simonsen pretendia com isso mostrar que, a seu ver, a posição ocupada pelo Brasil, na divisão internacional do trabalho, de fornecedor de matérias-primas, aprofundada durante a guerra, deveria mudar: essa participação na guerra não seria conducente ao progresso econômico, da forma como ocorria em nações como os Estados Unidos.

Neste ponto, Simonsen recorreu à obra de Colin Clark, para subsidiar a ideia de que o progresso econômico estaria associado à superação dessa inserção no comércio internacional, ligada ao fornecimento de gêneros primários, que a Segunda Guerra viera aprofundar. "Estudando diferentes casos, verificou Clark que, à medida que os países progridem economicamente, declina a proporção das populações engajadas nas indústrias primárias". ${ }^{485}$ A obra de Clark consultada por Simonsen foi possivelmente The conditions of economic progress, publicado em 1940. Além da citação (sem página e sem edição) no texto Alguns aspectos, o livro faz parte da Coleção Roberto Simonsen, o que indica que Simonsen muito provavelmente teve acesso à obra.

Colin Clark (1905-1989) foi um economista nascido em Londres, com atuação na GrãBretanha, nos Estados Unidos e na Austrália. Formou-se em química em Oxford, sendo posteriormente assistente de W. H. Beveridge, Allyn Young e A. M. Carr-Saunders. Fez parte do Economic Advisory Council, do qual Keynes era membro. Em 1931, assumiu o posto de lecturer de estatística em Cambridge, transferindo-se, em 1937, para a Universidade de Melbourne, na Austrália. Neste país, ocupou cargos públicos, como o de conselheiro econômico do governo do estado de Queensland. Foi professor-visitante da Universidade de Chicago e do Oxford Institute of Agricultural Economics, até se estabelecer em definitivo na Austrália, como consultor de pesquisas para a Universidade de Queensland. ${ }^{486}$

Clark teria sido um dos pioneiros das estimativas de renda nacional, melhorando as cifras existentes para o Reino Unido, a Austrália e a União Soviética. Suas contribuições

\footnotetext{
${ }^{483}$ SIMONSEN, 1943, p. 8.

${ }^{484}$ SIMONSEN, 1943, p. 8.

${ }^{485}$ SIMONSEN, 1943, p. 10.

${ }^{486}$ ARNDT, 2009.
} 
metodológicas lhe valeram o título de coautor, com Simon Kuznets, da "revolução estatística" que esteve associada às mudanças ocorridas na macroeconomia, a partir dos anos 1930. Clark teria usado de forma pioneira o conceito de produto nacional bruto (PNB), tendo calculado estimativas a partir da ótica da demanda agregada ${ }^{487}$; além disso, teria apresentado uma das primeiras estimativas do multiplicador keynesiano e uma comparação internacional entre o poder de compra de diferentes moedas nacionais. O livro referido por Simonsen, The conditions of economic progress (1940) teria importância por aprofundar essas contribuições ligadas à macroeconomia da renda nacional e por mostrar, pioneiramente, com evidência estatística substancial, a enorme clivagem existente entre países pobres e ricos, desenvolvendo a tese de que, ao longo do processo de progresso ou crescimento econômico, a estrutura ocupacional da economia modifica-se - o grosso da população transfere-se das indústrias primárias para as secundárias e terciárias.

De fato, o livro de Clark era mais um compêndio estatístico do que um tratado de teoria econômica: procurava, todavia, demonstrar algumas ideias por meio das estatísticas apresentadas, sempre numa metodologia comparativa. No primeiro capítulo, o autor defendia que as generalizações científicas diferem da mera acumulação de conhecimentos pelo fato de que, no caso das primeiras, utiliza-se o método comparativo. É a partir dessa ideia que Clark construiu sua obra: utilizou-se de dados de diversos países para fazer comparações internacionais do poder de compra da moeda e da renda nacional. Além disso, analisou, em separado, a produtividade das indústrias primária, manufatureira e terciária internacionalmente, para poder chegar a conclusões sobre a divisão do trabalho entre as indústrias e a divisão da renda entre fatores de produção.

No capítulo IX de seu livro, Clark mostrava a evolução da distribuição do trabalho entre os setores primário, secundário e terciário ao longo dos anos, para diversos países.

Podemos agora passar ao exame do que a generalização cuidadosa dos fatos disponíveis mostra ser o mais importante fato concomitante do progresso econômico, ou seja, o movimento da população trabalhadora da agricultura para a manufatura e da manufatura para o comércio e os serviços. ${ }^{488}$

Esta ideia de que as atividades primárias (husbandry) seriam menos enriquecedoras do que as manufatureiras e as mercantis (manufacture e merchandise) já estariam colocadas por William Petty em 1691, de acordo com Clark. E esse argumento se sustentava na evidência empírica de duas formas: tanto ao se analisar vários países quanto para a análise de um mesmo país ao longo do tempo. A população trabalhadora engajada em atividades primárias

\footnotetext{
487 O cálculo do PNB pela ótica da demanda agregada (DA) consiste em adicionar os dispêndios monetários com os três componentes da demanda: o consumo (C), o investimento (I) e os gastos públicos (G): DA = C + I + G. No caso de uma economia aberta, acrescenta-se o saldo da balança de transações correntes: $\mathrm{DA}=\mathrm{C}+\mathrm{I}+\mathrm{G}+(\mathrm{X}-\mathrm{M})$.

${ }^{488}$ CLARK, Colin. The conditions of economic progress. [1940]. 2. ed. London: Macmillan, 1951. p. 395.
} 
atingia um máximo de cerca de $70 \%$ em países como China, Turquia, Bulgária, Iugoslávia e algumas repúblicas centro-americanas, chegando a um mínimo de 7\% na Grã-Bretanha e 14\% na Bélgica. ${ }^{489}$ A análise ao longo do tempo para cada país é detalhada e diversa, pois cada nação apresenta formas diferentes de coleta de dados. A tendência à medida que os países progridem, denominada por Clark "lei de Petty", é a mesma para os diversos vários países: há uma diminuição da população empregada em atividades primárias e um aumento do contingente empregado em atividades manufatureiras e terciárias. A partir de certo momento, cessa o crescimento da proporção empregada em atividades secundárias e as atividades terciárias tomam a frente. Nas palavras de Simonsen, descrevendo o modelo de Clark:

A proporção da população aplicada em indústrias "secundárias", após alcançar um
certo limite, começa a decrescer, verificando-se o crescimento percentual da parte
que procura as chamadas atividades "terciárias". Essas atividades "terciárias" são
aquelas que, na divisão do trabalho, recebem relativamente em maior número
maiores remunerações.

As exceções a esse padrão seriam, de acordo com Simonsen, países como Argentina e Austrália, onde condições muito especiais de fertilidade do solo haviam permitido o rápido enriquecimento de proprietários de terra, permitindo que se passasse à fase de predomínio das atividades terciárias, de alta remuneração, sem atravessar a fase de predomínio industrial. Ainda assim, o equilíbrio econômico desses países seria instável, por isso estariam buscando a instalação de atividades industriais. ${ }^{491}$ Simonsen concluiu este ponto advogando a modernização do campo, de modo a permitir a produção em massa de gêneros alimentícios, e o desenvolvimento da indústria, auxiliado por alguma proteção. Do contrário, isto é, a prevalecer a lógica da inserção internacional associada ao fornecimento de gêneros primários, a população empregada na indústria declinaria e se concentraria em atividades primárias, pouco remuneradoras, criando-se uma situação de ricos proprietários de terra convivendo com uma população miserável. ${ }^{492}$

No decorrer do texto, Simonsen retornou à ideia de que tratados internacionais de livrecomércio entre países ricos e pobres são benéficos somente para o país industrializado, reforçando o argumento com a noção de que se promove a troca de produtos fracamente remunerados (os coloniais) por produtos altamente remunerados (manufaturados), por mais que haja igualdade, em valor monetário, entre as balanças de pagamento dos países em questão. Também os fluxos internacionais de capitais agiriam no sentido de beneficiar apenas os países ricos.

\footnotetext{
${ }^{489}$ CLARK, [1940] 1951, p. 397.

${ }^{490}$ SIMONSEN, 1943, p. 10-11.

${ }^{491}$ SIMONSEN, 1943, p. 11

${ }^{492}$ SIMONSEN, 1943, p. 13.
} 
Pode ocorrer que um país rico empreste a outro mais pobre capitais para o seu desenvolvimento, e que êsses capitais sejam, em boa parte, empregados na aquisição de produtos do país credor. Êste receberá, de fato, além dos juros e amortizações de seus capitais, os lucros resultantes da venda de seus produtos industrializados.

Por fim, outro argumento, mencionado por Simonsen, referente à especificidade dos países pobres era a questão cambial. "A desvalorização da moeda em certos países (...) reflete, não raro, a defesa automática da sua economia, empobrecida por circunstâncias independentes de sua vontade". ${ }^{493}$ Nesse sentido, o livre-comércio, praticado por meio da supressão de barreiras alfandegárias, e a estabilização cambial privariam os países de industrialização recente de duas armas importantes de defesa contra a concorrência. Essas nações não possuiriam, de acordo com Simonsen, os fatores de barateamento do custo de produção presentes nas nações ricas, como as facilidades de transporte, os aparelhamentos financeiros e os recursos técnicos de toda ordem. ${ }^{494}$ Em Evolução industrial do Brasil, de 1939, Simonsen já chamara a atenção para a depreciação cambial como fenômeno ligado ao desajuste existente entre a demanda interna de manufaturados à medida que o país se civiliza e a oferta insuficiente de produção interna e de divisas para obtenção desses produtos industriais: no texto de 1943, aparecia a ideia de "defesa automática" - em última análise, a desvalorização acabaria por incentivar a industrialização. Na brochura de 1948, "Direito Internacional Social”, o argumento é sofisticado, vindo à tona a ideia de piora nos termos de troca.

\begin{abstract}
A situação do intercâmbio dos países exportadores de manufaturas e países exportadores de produtos primários, impõem a estes uma situação desvantajosa nos termos de troca. Os produtos primários, de uma maneira geral, são inelásticos e, inversamente, os produtos manufaturados têm uma alta elasticidade. A evolução dos preços de uns e outros produtos mostra disparidade. As flutuações dos níveis de preços atingem mais duramente os produtos primários do que os manufaturados, depreciando os termos de troca dos países exportadores dos primeiros. Por outro lado, os preços dos produtos primários, via de regra, não são influenciados pelos países produtores, mas são ditados pelos próprios países manufatureiros. ${ }^{495}$
\end{abstract}

O texto em questão, "Direito Internacional Social”, era uma tentativa de estender a ideia de "direito social", isto é, o direito que não apenas iguala juridicamente, mas promove algum tipo de redução da desigualdade, para o plano das relações econômicas internacionais. Mais adiante, Simonsen argumentava que a manutenção da política praticada até o momento pelos países desenvolvidos de estabelecimento de acordos internacionais baseados na igualdade jurídica significaria a predominância dos interesses dos países ricos e a "perpetuação de uma desigualdade de fato". ${ }^{496}$ No lugar desse tipo de acordo pouco benéfico para o mundo menos desenvolvido, deveria ser perseguida, de acordo com Simonsen, uma "Política Social

\footnotetext{
${ }^{493}$ SIMONSEN, 1943, p. 17.

${ }^{494}$ SIMONSEN, 1943, p. 17.

${ }^{495}$ SIMONSEN, Roberto. "Direito Internacional Social" [1948]. IN: EIB, p. 344

${ }^{496}$ SIMONSEN, 1948, pp. 344-345.
} 
Internacional", que promovesse, "por meio de uma distribuição mais equitativa dos meios de produção, a eliminação das barreiras que impedem a difusão da propriedade no mundo". ${ }^{497}$ Em outras palavras, Simonsen reivindicava uma cooperação internacional mais efetiva, que estivesse associada não apenas ao intercâmbio de mercadorias, mas, também, à transferência de meios de produção, isto é, de inovações técnicas que permitissem aos países menos desenvolvidos mudar sua inserção internacional.

O texto foi publicado numa conjuntura cambial crítica para o Brasil. Com o fim da Segunda Guerra, houve uma reorganização do sistema monetário mundial, conduzida pelos interesses do grande vencedor, os Estados Unidos. O marco dessa nova ordem monetária e financeira mundial foi a Conferência de Bretton Woods (1944), na qual foi instituído o padrão monetário ouro-divisas, tendo o dólar como a moeda de reserva internacional. Para garantir o funcionamento do novo sistema, foram criados o Fundo Monetário Internacional, o GATT (Acordo Geral de Preços e Tarifas) e o Banco Internacional para Reconstrução e Desenvolvimento (BIRD). Em linhas gerais, o sistema deveria engendrar um novo equilíbrio monetário e financeiro internacional, baseado na convicção liberal de que esse equilíbrio seria atingido pela gradual retomada dos fluxos comerciais e financeiros entre as nações. Esse equilíbrio, todavia, não era possível num mundo em que países economicamente relevantes haviam sido destruídos pela guerra e a economia norte-americana crescera a taxas muito elevadas. A perspectiva liberal e multilateral dos EUA, que visava à retomada da concorrência internacional, não levou em conta as condições muito específicas do momento: o resultado foi um forte desequilíbrio nas transações em dólares e ouro do resto do mundo com relação aos Estados Unidos, gerando uma situação de escassez de dólares. 498

Esse cenário de escassez de divisas se manifestou no Brasil. O governo Dutra, empossado e 1946, adotou políticas de liberalização cambial e manutenção da paridade anterior à guerra, o que significava, na prática, uma revalorização cambial. Essas políticas se explicam pela crença, que se revelou uma ilusão, de que a situação do Brasil, no que tangia a suas reservas internacionais, era confortável e pelo ambiente internacional e doméstico favorável ao liberalismo econômico. Ademais, acreditava-se que o câmbio elevado poderia ajudar no combate à inflação, por meio dos canais de transmissão dos preços baixos de insumos importados. Em poucos anos, a ilusão de divisas se revelou, pois o Brasil estava

\footnotetext{
${ }^{497}$ SIMONSEN, 1948, pp. 348.

498 VIANNA, Sérgio Besserman. “Política econômica externa e industrialização: 1946-1951”. IN: ABREU, Marcelo de Paiva (org.). Ordem do progresso; cem anos de política econômica republicana 1889-1989. Rio de janeiro: Elsevier, 1990. pp. 105111. Sobre a Conferência de Bretton Woods e a organização monetária mundial que se definiu nesse momento ver, também, CARVALHO, Fernando Cardim de. "Bretton Woods aos 60 anos". Texto de discussão do IE/UFRJ. Disponível em: http://www.ie.ufrj.br/moeda/pdfs/bretton_woods_aos_60_anos.pdf . Acesso em: 13/08/2012.
} 
acumulando saldos em moedas inconversíveis e déficits em moedas fortes: os recursos disponíveis não permitiam, portanto, uma resolução do problema do balanço de pagamentos. Além disso, as importações sofriam a pressão do reequipamento pós-guerra e as exportações, de primários e, sobretudo, de manufaturados, caíram a partir de 1946, com a volta dos antigos ofertantes, inativos durante a guerra, ao mercado internacional. A situação crítica tornou necessários os controles cambiais e de importações. Em 1947, foi instituído o controle de câmbio por cooperação e, em 1948, introduziu-se o regime de contingenciamento quantitativo de importações, por meio das licenças prévias. ${ }^{499}$

O texto de Simonsen apareceu, portanto, numa conjuntura crítica. A trava imposta às importações tornava evidente que havia uma disparidade, um desequilíbrio, entre os países desenvolvidos, fornecedores de manufaturados, e os que dependiam ainda muito fortemente das divisas resultantes da agroexpotação para o funcionamento de suas economias. A crítica aos tratados de livre-comércio e o argumento de que a inserção no comércio internacional ligada ao fornecimento de mercadorias primárias não proporciona ao país riquezas permanentes são constantes na obra de Simonsen - a novidade deste texto, possivelmente relacionada à centralidade e à gravidade da situação das transações externas brasileiras no momento, era o embasamento econômico para a argumentação, partindo das elasticidades dos produtos primários e manufaturados.

Vale observar que o trecho deixa margem para dúvida: os produtos primários têm baixa elasticidade, mas não fica claro se se trata de elasticidade da oferta ou da demanda. Presumindo-se que seja elasticidade da oferta, o esquema esboçado se sustenta: com produção inelástica e sujeita a flutuações de preços sobre as quais não têm controle, os países primárioexportadores estariam muito mais sujeitos a flutuações do que os industrializados. Havendo, por exemplo, uma baixa do preço internacional de um produto primário dado, o país produtor, sem meios de ajustar a oferta (inelástica), acabaria contribuindo para a depressão ainda maior dos preços. Daí adviria a depreciação dos termos de troca, referida no trecho. Simonsen não citou a fonte desse argumento, mas se trata de uma tentativa de explicar, com mais rigor, por que a manutenção do tipo de inserção internacional que cabia aos países pouco desenvolvidos acarretaria uma piora de sua situação econômica.

Nesses textos referentes ao pós-guerra, algumas continuidades e diferenças são dignas de se notar. A referência a Clark, por exemplo, que buscou evidência empírica para a "lei de Petty”, segundo a qual progresso econômico é sinônimo de redução do setor primário da economia, acompanhada de um crescimento das atividades secundárias e terciárias, tinha um

${ }^{499}$ VIANNA, 1990, pp. 110-111. 
sentido semelhante ao recurso à obra de Woytinsky via Manoilescu, no início dos anos 1930 . Naquele caso, tratava-se de dar substância à teoria protecionista do comércio internacional que defendia a elevação da produtividade global da economia, por meio da instalação da atividade industrial, mais produtiva que a agricultura e o extrativismo. Woytinsky mostrava este ponto: de fato, os números mostravam que a indústria era mais produtiva que a agricultura. Colin Clark, por sua vez, demonstrava, por meio de pesquisa estatística aprofundada, que a dinâmica do progresso econômico passaria necessariamente por uma mudança na distribuição ocupacional da população trabalhadora: da agricultura para a indústria, até um certo ponto, e depois para as atividades terciárias. Nos dois casos, trata-se da busca de estudos baseados em estatística para dar sustentação a ideias econômicas.

Diferentemente das elaborações de Woytinsky e Manoilescu, no entanto, a argumentação de Clark implica numa ideia de tipologia do progresso econômico: ao inventariar estatísticas para os diversos países, mostrando que todos, com raras exceções, seguiram trajetórias semelhantes, Clark dava a entender que havia um caminho típico do desenvolvimento econômico, e que este passaria pelo desenvolvimento das atividades secundárias e terciárias, com uma diminuição da população empregada nas primárias. O próprio autor reconhecia que o argumento é antigo, alcunhando-o de "lei de Petty". Aqui, o sentido da referência é similar ao do conceito de "economia nacional", de Adolph Wagner, para quem as economias passariam por "fases típicas", até atingirem a fase em que poderiam ser consideradas, de fato, economias nacionais, isto é, um todo orgânico, integrado.

Neste ponto, a pluralidade das sintonias de Simonsen é bem claro. Se utiliza, em vários momentos de sua obra, autores que argumentam na direção de um processo relativamente padrão de desenvolvimento, como Clark e Wagner, Simonsen produziu textos de história que se referem justamente à especificidade da evolução econômica do Brasil: nascido como consequência do expansionismo português e refém dos ciclos da economia colonial o Brasil seria, por natureza, uma economia distinta dos países ricos. Esse sentido de uma especificidade da economia brasileira é reforçado no pós-guerra, quando Simonsen enfatiza a necessidade de uma política econômica distinta para o Brasil e as nações latino-americanas que colaboraram com os Aliados durante o conflito mundial. Não se tratava de manter a renda nacional e buscar o pleno emprego, mas, sim, de elevar muito esta renda e buscar uma reinserção no comércio internacional.

O sentido de especificidade fica claro no texto de 1947, referente ao Plano Marshall, quando Simonsen falou em nome das nações latino-americanas: "Os norte-americanos e europeus, que desfrutam alto padrão de vida, não compreendem, em sua maioria, as condições 
de penúria em que estão penosamente evoluindo os povos da América Latina". ${ }^{500}$ O texto era uma crítica ao papel reservado à América Latina no Programa de Recuperação Europeia (conhecido como Plano Marshall), desenvolvido na Conferência de Paris, em 1947, com o objetivo de reconstruir as nações da Europa, trazendo suas economias a um estágio em que fosse possível crescer. Na interpretação de Simonsen, o Plano tinha um caráter de "defesa da civilização ocidental" da ameaça da coletivização, tendo em vista o poder da União Soviética no pós-guerra, com o alargamento da sua área de influência na Europa Oriental. ${ }^{501}$

Mais uma vez, caberia ao Brasil e aos países latino-americanos um papel subordinado. Dentro do Plano, que previa auxílio de capitais e suprimentos externos, cooperação econômica, esforço interior de produção e estabilidade financeira interna, para os países europeus, deveria ser feito um esforço, por parte dos Estados Unidos e do resto do mundo, de fornecimento, à Europa, dos recursos necessários à sua reconstrução. Isso passaria por um grande contingente de importações, por parte dos países europeus, do continente americano como um todo. A distribuição dessas importações seria, entretanto, desfavorável à América Latina: caberia ao subcontinente o fornecimento de alimentos, forragens, fertilizantes e madeira.

Seremos chamados a expandir nossas atividades extrativas, agrícolas e mineradoras,
para colaborar nesse plano com a contribuição de matérias primas e produtos semi-
coloniais. (...) Conhecemos, por outro lado, por penosa experiência recente, os
graves danos que sofrerão as nossas economias com êsse deslocamento de nossos
fatôres de produção, para atividades sem garantia de continuidade e de baixo
rendimento econômico. Poderemos ser atingidos, na previsão do relatório de Paris,
por severa diminuição no fornecimento de bens de produção, por parte dos Estados
Unidos, porque a Europa, certamente, reclamará prioridade para suas
necessidades. ${ }^{502}$ a tala

Além deste problema do tipo de inserção baseado em atividades "semi-coloniais" e "sem garantia de continuidade", haveria um outro, relacionado a ele. Sendo necessário expandir as exportações, seria também preciso encontrar financiamento que desse conta desse incremento: esses recursos, todavia, não existiam, de acordo com Simonsen. "A América Latina, entretanto, não está em condições de financiar, com seus próprios recursos, parte da reconstrução da Europa". ${ }^{503}$ Simonsen concluiu com uma série de críticas e reivindicações com relação ao Plano de Reconstrução Europeia. O Plano traduzia apenas os interesses dos países europeus, não incluindo, como um plano de reconstrução internacional deveria, os

\footnotetext{
${ }^{500}$ SIMONSEN, Roberto. O Plano Marshall e suas prováveis repercussões econômicas na América Latina. Rio de Janeiro: [s/n], 1947. Relatório apresentado pelo Senador Roberto Simonsen na XXVI Reunião Plenária da Comissão Executiva do Conselho Interamericano de Produção. p. 12.

${ }^{501}$ SIMONSEN, 1947, p. 4.

${ }^{502}$ SIMONSEN, 1947, p. 11.

${ }^{503}$ SIMONSEN, 1947, p. 15.
} 
anseios das "nações pouco desenvolvidas economicamente". ${ }^{504}$ Embora devam aplaudir os desígnios norte-americanos, expressos no Plano, os países latino-americanos deveriam pleitear fossem atendidas as suas aspirações, por meio do fornecimento de produtos que de fato concorressem para a intensificação de sua economia. Simonsen também advogava a maior cooperação entre os países americanos, propondo a organização de uma Comissão de Cooperação Econômica, que estudasse os meios para se promover tal cooperação de forma mais eficiente e efetiva. ${ }^{505}$

Simonsen certamente estava inserido no ambiente intelectual e político que redundou na criação da Comissão Econômica para América Latina, a CEPAL. Simonsen faleceu em 1948, portanto antes ainda da publicação do primeiro estudo significativo produzido na CEPAL, por Raúl Prebisch, em 1949. Suas reivindicações, no entanto, expressas de forma enfática no Relatório apresentado em 1947, refletiam esse ambiente em que se passou a pensar os interesses latino-americanos e a se incluir o Brasil nessa realidade econômica da América Latina. Esse processo de criação de uma identidade econômica latino-americana estava ligado, como bem demonstra o texto de Simonsen, ao contexto mundial de reconstrução econômica pós-guerra.

O pós-guerra determinou mudanças importantes na política externa dos Estados Unidos, no que se refere à América do Sul. Ao longo do conflito mundial, prevalecera a Política da Boa-Vizinhança, iniciada ainda no anos 1930, baseada na ideia de que a cooperação econômica e cultural entre os EUA e os países ao sul do Rio Grande seria a melhor forma de os Estados Unidos reforçarem sua hegemonia continental. O temor de que a pobreza latinoamericana resultasse em revoluções de inclinação socialista ou comunista e de que a fragilidade militar dos países do subcontinente favorecesse a uma invasão do Eixo no hemisfério americano fizeram com que, durante o período de guerra, as autoridades norteamericanas se preocupassem ainda mais com as questões latino-americanas. Em 1940, o governo norte-americano criou o Office of the Coordinator of Inter-American Affairs. ${ }^{506} \mathrm{O}$ coordenador para assuntos inter-americanos era Nelson Rockfeller, cujo plano de política externa para a América Latina fora aceito pelo presidente Roosevelt, cioso de reforçar os laços entre as "duas Américas", num contexto em que a Alemanha estava se expandindo e o alinhamento de países sul-americanos com o Eixo parecia uma ameaça real, ao menos a julgar

\footnotetext{
${ }^{504}$ SIMONSEN, 1947, p. 15.

${ }^{505}$ SIMONSEN, 1947, p. 15.

${ }^{506} \mathrm{O}$ nome original do órgão era Office for Coordination of Commercial and Cultural Relations between the Americas, mudado no ano seguinte para o nome citado acima. Sobre esta fase das relações entre Brasil e Estados Unidos, que teria tido papel importante no processo de americanização da sociedade brasileira, ver TOTA, Antonio Pedro. $O$ imperialismo sedutor: a americanização do Brasil na época da Segunda Guerra. São Paulo: Companhia das Letras, 2000. pp. 49-53.
} 
pelos alguns discursos do presidente Vargas. A estratégia de Rockfeller para região era simples: afastar da América Latina produtos alemães, possíveis concorrentes dos americanos e debelar as ameaças socialistas (e fascistas) por meio da intensa propaganda do modelo norte-americano: consumo, progresso material e bons salários.

O fim da guerra e a emergência dos Estados Unidos como superpotência mundial promoveriam mudanças significativas nessa política. A ênfase e, a partir do governo Truman, empossado em 1945, passava a ser o combate à ameaça soviética, no âmbito da Guerra Fria que se iniciava: a reconstrução europeia fazia parte desse projeto de contenção ao socialismo soviético. A cooperação estreita, que resultara, por exemplo, no encaminhamento da questão siderúrgica no Brasil, com a construção da usina de Volta Redonda, não existiria mais, ao menos naqueles termos. A crítica de Simonsen ao Plano Marshall aparece nesse momento de arrefecimento de relações muito promissoras nos anos anteriores.

A criação de uma região econômica latino-americana, no âmbito das instituições internacionais, esteve associada, segundo Leslie Bethell, à emergência dos Estados Unidos como potência mundial fortalecida e à formação, ainda durante a guerra, do Ethnographic Board, entidade que reunia especialistas de diversas áreas do conhecimento com o objetivo de formular políticas e promover o ensino e a pesquisa, sobre as diversas regiões do globo. Uma das tarefas do Board foi a divisão do mundo em "continentes": o continente americano foi dividido em Estados Unidos e América Latina. Essa divisão foi acompanhada de uma regionalização, que apresentava as áreas que possuíam coesão política e cultural. A América Latina foi apresentada pelo Board como uma das regiões mais homogêneas do globo, do ponto de vista da história, da língua, da religião e das estruturas políticas. Essa visão oficial norte-americana teria influenciado, segundo Bethell, vários organismos internacionais, inclusive a própria ONU, no âmbito da qual foi criada a CEPAL. ${ }^{507}$

Dessa forma, a argumentação de Simonsen, no tocante à América Latina, estava inserida nesse quadro de construção de uma identidade econômica e cultural homogênea para a América Latina, que já não seria mais a grande prioridade de política externa dos Estados Unidos. A incorporação de interesses enfaticamente latino-americanos - e não mais exclusivamente brasileiros - à formulação de Simonsen reflete esse cenário do pós-guerra, em que a América Latina surgia como área internacionalmente reconhecida como homogênea, sobre a qual os Estados Unidos exerceriam domínio político e econômico. Ao mesmo tempo, a noção de que a América Latina seria um todo coeso, que era a posição oficial norte-

\footnotetext{
${ }^{507}$ BETHELL, Leslie. “O Brasil e a ideia de 'América Latina' em perspectiva histórica. IN: Estudos Históricos. vol. 22; n. 44. Rio de Janeiro: CPDOC, 2009. pp. 289-321.
} 
americana, fomentou o surgimento de ideias questionadoras do domínio estadunidense: o próprio relatório de Simonsen sobre o Plano Marshall é um exemplo desse tipo de questionamento. Se deixou de contar com as oportunidades de política externa oferecidas pela Política da Boa-Vizinhança, uma América Latina que se pensava mais coesa passava a refletir sobre seus problemas econômicos de forma mais integrada por meio, por exemplo, de instituições como a CEPAL, criada em 1948. 


\section{Conclusão}

Roberto Simonsen faleceu em 1948, quando se iniciavam as articulações e reflexões que culminariam na formação da CEPAL e na produção de um pensamento econômico latinoamericano, que, por meio das obras de Prebisch e Furtado, granjeou um lugar na história do pensamento econômico, em nível mundial. Essa coincidência de datas e as afinidades de ideias fizeram com que Simonsen fosse visto como "antecipador" da economia do desenvolvimento no Brasil. Mais ainda, Simonsen tem sido visto como pioneiro do “desenvolvimentismo" no Brasil.

Entendida por Bielschowsky como ideologia de transformação social, baseada na industrialização induzida pelo Estado, a categoria "desenvolvimentismo" mostrou-se operacional para o estudo feito pelo autor do pensamento econômico brasileiro do período 1930-64. Este conceito, todavia, nem sempre tem sido historicizado: tem sido utilizado para caracterizar o projeto político de governos brasileiros dos anos Vargas até o início do século XXI. ${ }^{508}$ Esse tipo de procedimento - encontrar traços de "desenvolvimentismo", ou ausência dele, em projetos políticos de governos da Primeira República ao pós-Regime Militar - não parece producente, do ponto de vista da construção do conhecimento histórico. Escamoteiamse assim as especificidades dos desafios que se apresentavam, em cada conjuntura, aos governos, aos formuladores de política econômica e aos intelectuais. Oblitera-se também a diversidade das respostas dadas e de tipos de reflexão intelectual ensejados por cada situação conjuntural.

Essa busca por "desenvolvimentismo" parece refletir, no fundo, uma busca por um projeto político em que haja uma convergência de interesses. É certo que a Era Vargas e o interregno democrático 1945-64 foram períodos em que, com o patrocínio do Estado, o capitalismo que se instalava no Brasil fez concessões à classe trabalhadora. Também foi um período em que se buscaram formas estratégicas de relacionamento com o capital estrangeiro, que, com a mediação do Estado, facilitou, de algum modo, a implantação do capitalismo no país. Como legado desse período em que o Estado agiu como árbitro do compromisso entre as classes sociais e das disputas com o capital externo, parece ter ficado a noção de que a simples presença do Estado na economia - como empresário ou como planejador - é sinônimo de um projeto político desenvolvimentista. Mais ainda, busca-se reencontrar essa conjuntura econômica e política muito específica, que deu ensejo ao surgimento da ideologia desenvolvimentista na primeira metade do século XX.

Se, para se fazer uma história dos projetos políticos ou mesmo uma história de política

\footnotetext{
508 Ver BRESSER-PEREIRA, Luiz Carlos. "Do antigo ao novo desenvolvimentismo na América Latina". Texto para Discussão, n. 274. São Paulo: EESP/FGV, 2010.
} 
econômica, o uso não historicizado da categoria desenvolvimentismo é pouco producente, a situação não é diferente no que tange à história do pensamento econômico. Nesse campo, há que diferenciar entre o projeto político ligado à ideologia desenvolvimentista, presente, sobretudo, nos círculos industrialistas e estatais, a partir dos anos 1930, e a construção de um novo conhecimento em economia. Os dois processos estão relacionados, mas não são a mesma coisa. A emergência, na América Latina e nos países centrais, da economia do desenvolvimento (development economics), que incorporou à agenda dos economistas questões como oferta ilimitada de mão-de-obra, escassez de poupança e estrangulamento cambial não foi um processo simétrico ao robustecimento do aparato estatal no Brasil e à utilização do planejamento como estratégia de política econômica.

Ainda assim, a corrente dos economistas ligados à CEPAL, que produziu contribuições teóricas relevantes para a economia do desenvolvimento, nas décadas de 1950 e 1960, é vista como a realização, no plano teórico e intelectual, de aspirações político-ideológicas desenvolvimentistas. Não cabe discutir aqui o quão verdadeira é essa relação: o que se quer frisar é que, a partir dessa associação entre concretização teórica da ideologia desenvolvimentista e corrente cepalina, o pensamento econômico brasileiro não liberal anterior à CEPAL tem sido, em larga medida, avaliado em termos de quanto teria contribuído para que surgisse o estruturalismo cepalino. Mais do que tentar encontrar em Roberto Simonsen germens de ideias posteriores, este trabalho procurou mostrar como Simonsen respondeu às questões econômicas com as quais se defrontou. Essas respostas, como vimos, estiveram associadas à construção de uma interpretação da história econômica do Brasil e à apropriação de ideias de difusão internacional.

Simonsen teve uma trajetória relacionada aos processos econômicos e políticos em curso no Brasil. Iniciou sua trajetória intelectual na Escola Politécnica de São Paulo, onde se formou engenheiro e tomou contato com um conhecimento técnico, ligado às questões da organização da produção. Atuou como empresário do ramo da construção civil, inserido na lógica da modernização no Brasil: um processo ligado à sofisticação da esfera do consumo das elites, sem que se alterasse a estrutura produtiva da economia. A Companhia Construtora de Santos, de propriedade de Simonsen, construiu edifícios como a Bolsa do Café, em Santos, símbolo do Brasil que modernizava sem grandes pretensões à industrialização. Suas preocupações intelectuais iniciais refletiam questões de administração da produção e organização científica do trabalho.

Ao longo dos anos 1920 e 1930, Simonsen foi-se destacando no meio empresarial paulista e nacional. Opositor do regime Vargas nos primeiros anos, esteve ao lado da Frente 
Única Paulista em 1932. A aproximação com os círculos governamentais federais se daria, a partir de 1937, com a participação no Conselho Federal de Comércio Exterior, substituindo Euvaldo Lodi. Os Conselhos Técnicos foram órgãos que permitiram uma participação efetiva de membros da burguesia industrial no governo, o que se articulava aos projetos de uma classe que procurava estabelecer-se como hegemônica no Brasil, fazendo o Estado implantar políticas convergentes com seus interesses.

Os anos 1930 e 1940 foram o período mais fértil da produção intelectual de Simonsen. Em As crises no Brasil (1930), Simonsen estudou a crise que se desenrolava no momento, usando para isso a tipologia de Maurice Ansiaux e reportando-se ao diagnóstico de Albert Aftalion. O texto "As finanças e a indústria" (1931), incluído na coletânea Á margem da profissão, é um marco importante em que Simonsen mostrava seu entusiasmo com a teoria protecionista de Mihail Manoilescu, subsidiada por dados estatísticos compilados por Wladimir Woytinsky. No debate de 1935, em torno do Tratado Comercial Brasil-Estados Unidos, Simonsen fez uma defesa do protecionismo para a qual mobilizou argumentos presentes nos autores alemães Karl Rodbertus e Alfred Wagner, relacionados ao papel do Estado na regulação do mercado e ao questionamento do princípio do livre comércio. Também utilizou, em sua argumentação, argumentos históricos, baseados na reconstituição das políticas tarifárias do Brasil e de nações desenvolvidas como França, Inglaterra e Estados Unidos. A conclusão é que o Brasil não deveria assinar o Tratado: deveria adotar políticas de proteção à indústria e de regulação do comércio exterior, com discriminação de importações.

No âmbito desses embates políticos em defesa dos interesses industriais, Simonsen produziu sua obra mais conhecida, a História econômica do Brasil (1937), como curso a ser ministrado na Escola Livre de Sociologia e Política. A ELSP tinha um projeto pedagógico ligado à ideia de construção de quadros, dentro da elite paulista, capazes de atuar nos negócios do Estado. O livro de Simonsen contém uma interpretação da história do Brasil, plasmada a partir da moldura de João Lúcio de Azevedo, que enfatizava o caráter cíclico da riqueza produzida na economia colonial, baseada na exportação de gêneros primários. As fontes de riquezas estáveis seriam as manufaturas e indústrias, impedidas de vicejar no Brasil, devido às políticas coloniais. Simonsen ia buscar na história, na colonização e na especificidade da evolução econômica do Brasil, as respostas para as perguntas que norteavam suas preocupações: por que o Brasil é um pais atrasado? Por que não se industrializou?

Se a resposta a essa pergunta passa pela história, isto é, se o desenvolvimento econômico é algo historicamente construído, é possível que se proponha a industrialização planejada 
como estratégia de superação dos entraves que dificultavam o progresso brasileiro. Essa proposta de planejamento, apresentada por Simonsen no âmbito do Conselho Nacional de Política Industrial e Comercial, foi severamente criticada por Eugênio Gudin, em 1945. O debate Simonsen-Gudin tem sido reconhecido como momento-chave pela historiografia do pensamento econômico brasileiro, por ter sido uma acirrada discussão de ideias, em que se defrontaram duas maneiras distintas de se pensar os problemas econômicos e, no fundo, duas visões diferentes de Brasil. Ao longo da controvérsia com Gudin, Simonsen lançou mão dos argumentos de Carl Landauer, economista alemão, radicado nos EUA, a cujo livro, pertencente à Coleção Roberto Simonsen, foi possível ter acesso: as anotações manuscritas de Simonsen à margem, bem como seus destaques no texto, conformam um caso em que a sintonia entre os autores pode ser vista concretamente por meio desses registros físicos da apropriação de um livro.

Para além do debate do planejamento, Simonsen preocupou-se, nos anos 1940, com as questões da organização da economia mundial - e latino-americana - no pós-guerra. Utilizou a obra de Colin Clark, considerado um pioneiro da economia do desenvolvimento, para mostrar que o processo de desenvolvimento dos países está relacionado à diminuição proporcional dos setores primários e crescimento do secundário e terciário. Em sua crítica ao Plano Marshall, que beneficiaria apenas os países europeus, em detrimento da América Latina, à qual ficaria reservado o papel de fornecedor de gêneros primários, Simonsen já falava em nome das nações latino-americanas, em consonância com o projeto, presente nos círculos estatais norte-americanos, de se criar uma região econômica e cultural latinoamericana dotada de coesão e homogeneidade. Simonsen questionava a inserção latinoamericana como fornecedora de gêneros primários por meio de um raciocínio que explicitava a dinâmica deterioração dos termos de troca.

Partindo de uma perspectiva de reconstituição histórica das ideias econômicas, procuramos fazer um estudo do pensamento econômico de Roberto Simonsen. A pesquisa incluiu aspectos institucionais e políticos que diversas vezes não caberiam no escopo de uma história da análise econômica, no sentido atribuído por Schumpeter. Muito da riqueza da trajetória intelectual de Simonsen está, de fato, nesses aspectos pouco analíticos: o curso de história que ministrou, sua atuação parlamentar e como empresário, o tipo de cargo público que ocupou - tudo isso foi constitutivo de seu pensamento econômico.

A dimensão de difusão internacional das ideias econômicas, que esta dissertação procurou incluir, permite lidar, de algum modo, com o dilema da construção de um pensamento econômico nacional numa nação em formação. Era um dilema que, como vimos, 
afetava o próprio Simonsen: ao ver-se diante de tantos entraves para que o Brasil se tornasse uma nação rica e industrializada, escreveu uma história econômica do Brasil, buscando na colonização as raízes para o atraso brasileiro. Ao buscar as sintonias de Simonsen com autores estrangeiros contemporâneos e as influências de pensadores anteriores, destacam-se processos de seleção, apropriação e adaptação de ideias, que permitiram identificar os traços de um pensamento econômico brasileiro em formação. 


\section{REFERÊNCIAS}

\section{Fontes}

\section{I.A) Fontes oficiais e de arquivo}

Acervo da Biblioteca Nacional

Atas constantes dos Anais da Câmara dos Deputados. Volumes XV e XVI (1935).

Arquivo Histórico da Escola Politécnica da USP

Pasta do ex-aluno Roberto Simonsen.

Pasta do ex-professor Brazilio de Campos.

Fundo Escola Polytechnica. Caixas 19, 20 e 21.

Arquivo do Centro de Documentação (CEDOC) da ELSP

Dossiê Roberto Simonsen.

Informações e Programas (1933-34).

Currículos do curso de Bacharelado em Ciências Políticas e Sociais.

Biblioteca do Instituto de Filosofia e Ciências Humanas da Unicamp

Obras pertencentes à Coleção Roberto Simonsen.

Presidência da República

Decreto N. 542, de 24 de dezembro de 1935, que promulga o Tratado de Comércio entre os Estados Unidos do Brasil e os Estados Unidos da América.

\section{I.B) Imprensa}

Folha da Manhã, 19/07/1932, 29/07/1932, 23/08/1932, 03/09/1932, 28/05/1933, 26/05/1948.

A Gazeta, 07/04/1935.

Diário de São Paulo, 12/04/1936.

\section{I.C) Publicações dos textos de Roberto Simonsen}

O calçamento de asphalto em São Paulo. São Paulo: Typographia Brazil de Rothschild, 1923. (publicado em coautoria com Luiz Augusto Pereira Queiroz)

As crises no Brasil. São Paulo: São Paulo Editora, 1930.

A construção de quartéis para o Exército. São Paulo: sem editora, 1931.

Á margem da profissão. São Paulo: Ed. São Paulo, 1932.

Rumo à verdade. São Paulo: São Paulo Editora, 1933.

Aspectos da política econômica nacional. São Paulo: Empresa Graphica da "Revista dos Tribunaes", 1935.

Aspects of national political economy. São Paulo: sem editora, 1935. 
Historia economica do Brasil. São Paulo: Companhia Editora Nacional, 1937. (Reedição utilizada nas referências: História econômica do Brasil. 8. ed. São Paulo: Companhia Editora Nacional, 1978).

A industria em face da Economia Nacional. São Paulo: Empresa Graphica da "Revista dos Tribunaes", 1937.

Aspectos da historia economica do café. Instituto Histórico e Geográfico Brasileiro, 1938.

A evolução industrial do Brasil. São Paulo: FIESP, 1939.

Economic resources and population shifts. Washingtion, DC: Eighth American Scientific Congress, 1940.

Alguns aspectos da Política Econômica mais conveniente ao Brasil no período de apósguerra. São Paulo: FIESP, 1943.

Ensaios sociais, políticos e econômicos. São Paulo: FIESP, 1943.

"A planificação da economia brasileira" [1944]. IN: SIMONSEN, Roberto, GUDIN, Eugênio e VON DOELLINGER, Carlos. A controvérsia do planejamento na economia brasileira. $3^{\mathrm{a}}$ edição. Brasília: IPEA, 2010.

"O planejamento da economia brasileira - Réplica ao Sr. Eugênio Gudin" [1945]. IN: SIMONSEN, Roberto, GUDIN, Eugênio e VON DOELLINGER, Carlos. A controvérsia do planejamento na economia brasileira. 3. ed. Brasília: IPEA, 2010.

A engenharia e a indústria. São Paulo: FIESP, 1945.

O Plano Marshall e suas prováveis repercussões econômicas na América Latina. Rio de Janeiro: [s/n], 1947. Relatório apresentado pelo Senador Roberto Simonsen na XXVI Reunião Plenária da Comissão Executiva do Conselho Interamericano de Produção

Evolução industrial do Brasil e outros estudos. São Paulo: Companhia Editora Nacional, 1973. (org. Edgar Carone).

\section{I.D) Escritos contemporâneos ${ }^{509}$}

AFTALION, Albert. Monnaie, prix et change: expériences récentes et théorie. Bordeaux: Cadoret, 1927.

"La Crise Mondiale". IN: La Revue de Paris. vol. 4 (jul-ago), 1930. p. 296. Acervo da Bibliothèque Nationale de France. Disponível em: < http://visualiseur.bnf.fr >. Acesso em: 01/09/2013.

ANSIAUX, Maurice. Traité d'économie politique. Tome troisième. Paris: Marcel Giard, 1926.

\footnotetext{
${ }^{509}$ As traduções para o português dos trechos citados desses escritos, vários deles em língua estrangeira no original, foram feitas pelo autor.
} 
AZEVEDO, João Lúcio de. Épocas de Portugal económico. [1928]. 4 $4^{\mathrm{a}}$ edição. Porto: Imprensa Portuguesa, 1978.

CLARK, Colin. The conditions of economic progress. [1940]. 2. ed. London: Macmillan, 1951.

GUDIN, Eugênio. Princípios de economia monetária. [1943]. 2a edição. Rio de Janeiro: AGIR, 1956.

. "Rumos de política econômica". [1945]. IN: SIMONSEN, Roberto, GUDIN, Eugênio e VON DOELLINGER, Carlos. A controvérsia do planejamento na economia brasileira. $3^{\text {a }}$ edição. Brasília: IPEA, 2010.

LANDAUER, Carl. Theory of national economic planning. Berkeley: University of California, 1944.

LIST, Georg Friedrich. Sistema nacional de economia política. [1841]. São Paulo: Abril Cultural, 1983.

MANOILESCU, Mihail. Theoria do proteccionismo e da permuta intenacional. São Paulo: CIESP, 1931. (Reedição da tradução de 1931: Teoria do protecionismo e da permuta inernacional. Rio de Janeiro: Capax Dei, 2011).

PROKOPOVICH (ou PROKOPOVICZ), Sergei Nikolaievich. L'industrialisation des pays agricoles et la structure de l'économie mondiale après la guerre. Neuchâtel: Éditions de la Baconnière, 1945.

RODBERTUS, Johann Karl. Le capital. Paris: V. Giard \& E. Brière, 1904.

. "Das Kapital. Vierter sozialer Brief an von Kirchmann" [1854/1899]. IN:

$\overline{\text { Gesammelte Werke und Briefe. Abteilung I, Band 2. Osnabrück: Otto Zeller, 1971. (Edição }}$ fac-similar da reedição de 1899, feita por Adolph Wagner).

VARGAS, Getúlio. A nova política do Brasil. I. Da Aliança Liberal às realizações do $1^{\circ}$ ano de governo. Rio de Janeiro: Livraria José Olympio Editora, 1938.

WAGNER, Adolph. Les fondements de l'économie politique. t. II. [1876]. Paris: V. Giard \& E. Brière, 1909.

WOYTINSKY, Wladimir. Les États Unis de l'Europe. Bruxelles: Maison Nationale d'éditions L'Eglantine, 1927.

Stormy Passage. New York: The Vanguard Press, 1961.

\section{Bibliografia geral}

ABREU, Marcelo de Paiva e SOUZA, Pedro Carvalho Loureiro de. "Palatable foreign control': British money doctors and central banking in South America". Texto para Discussão, no 597. Rio de Janeiro: PUC Rio, 2011. 
ABREU, Marcelo de Paiva. "Crise, crescimento e modernização autoritária: 1930-1945". IN: (org.). Ordem do progresso; cem anos de política econômica republicana 18891989. Rio de janeiro: Elsevier, 1990.

O Brasil e a economia mundial, 1930-1945: políticas econômicas externas e relações econômicas internacionais. Rio de Janeiro: Civilização Brasileira, 1999.

AIDAR, José Luiz; CYTRYNOWICZ, Roney; ZURQUIM, Judith. Escola Politécnica 100 anos. São Paulo: Expressão e Cultura, 1993.

ARNDT, H. W. "Clark, Colin Grant (1905-1989)". IN: The New Palgrave Dictionary of Economics. Online Edition. Palgrave Macmillan, 2009.

BACKES, Ana Luíza. Fundamentos da ordem republicana: repensando o Pacto de Campos Sales. Brasília: Plenarium, 2006.

BARROS, Gustavo. "Discurso e contexto: política siderúrgica no primeiro governo Vargas (1930-1937)". Texto de Discussão apresentado no Seminário Hermes \& Clio. São Paulo: FEA/USP, 2012.

BASTOS, Pedro Paulo Zahluth. "O projeto nacionalista de Vargas". IN: BASTOS, Pedro Paulo Zahluth e FONSECA, Pedro Cezar Dutra. (orgs.) A Era Vargas: desenvolvimentismo, economia e sociedade. São Paulo: Editora da Unesp, 2012.

BATALHA, Claudio Henrique de Morais. O movimento operário na Primeira República. Rio de Janeiro: Zahar, 2000.

BEIRED, José Luis Bendicho. Sob o signo da nova ordem: intelectuais autoritários no Brasil e na Argentina (1914-1945). São Paulo: Loyola, 1999.

BETHELL, Leslie. "O Brasil e a ideia de 'América Latina' em perspectiva histórica. IN: Estudos Históricos. vol. 22; n. 44. Rio de Janeiro: CPDOC, 2009.

BIELSCHOWSKY, Ricardo. Pensamento econômico brasileiro: o ciclo econômico do desenvolvimentismo. Rio de Janeiro: Contraponto, 2000.

“Eugênio Gudin”. Estudos avançados. [online]. vol.15, n.41. 2001. pp. 98-99.

BLAUG, Mark. Teoría económica en retropección. [1962] México, D.F.: Fondo de Cultura Económica, 2001.

BOIANOVSKY, Mauro. "Friedrich List and the economic fate of tropical countries". IN: Social Science Research Network, 2011. Disponível em: < SSRN: http://ssrn.com/abstract=1810846 >.

BRESSER-PEREIRA, Luiz Carlos. "Do antigo ao novo desenvolvimentismo na América Latina". Texto para Discussão, n. 274. São Paulo: EESP/FGV, 2010.

BRUZZI CURI, Luiz Felipe e CUNHA, Alexandre Mendes. "Redimensionando a contribuição de Roberto Simonsen à controvérsia do planejamento: pioneirismo e sintonia". IN: Anais do $39^{\circ}$ Encontro Nacional de Economia: Foz do Iguaçu, ANPEC, 2011. 
BURDEAU, François. "Rodbertus, Johann Karl (1805-1875)". IN: Enciclopaedia Universalis. (digital). Consultado em: 18 de março de 2013.

CARDOSO, José Luís. "Reflexões periféricas sobre a difusão internacional do pensamento econômico". Nova Economia, vol. 19, nº 2. Belo Horizonte, 2009.

CARVALHO, Fernando Cardim de. "Bretton Woods aos 60 anos". Texto de discussão do IE/UFRJ. Disponível em: http://www.ie.ufrj.br/moeda/pdfs/bretton_woods_aos_60_anos.pdf . Acesso em: 13/08/2012.

CEPÊDA, Vera Alves. Roberto Simonsen e a formação da ideologia industrial no Brasil: limites e impasses. São Paulo: FFLCH/USP, 2003. Tese de Doutorado.

CHINYAEVA, Elena. Russians outside Russia: the émigré community in Czechoslovakia, 1918-1938. München: Oldenbourg Verlag, 2001.

CLARO, Silene Ferreira. Revista do Arquivo Municipal de São Paulo: um espaço científico e cultural esquecido. São Paulo: FFLCH/USP, 2008. Tese de Doutorado.

CLAVIN, Patricia. " 'Money talks' - Competition and cooperation within the League of Nations". IN: FLANDREAU, Marc. Money doctors: the experience of international financial advising 1850-2000. New York: Routledge, 2003.

CORSI, Francisco Luis. "Brasil e Argentina: uma análise das políticas econômicas do período 1930-1945”. In: Revista de Economia Política e História Econômica, n. 5, julho de 2006.

DEANE, Phyllis. A evolução das ideias econômicas. Rio de Janeiro: Zahar, 1980.

DIAS, Sônia. "Roberto Simonsen". IN: Dicionário histórico-biográfico brasileiro: pós-1930. Rio de Janeiro: FGV/CPDOC, 2001.

DINIZ, Eli. Empresário, Estado e capitalismo no Brasil: 1930-1945. Rio de Janeiro: Paz e Terra, 1978.

DRAIBE, Sônia. Rumos e metamorfoses um estudo sobre a constituição do Estado e as alternativas de industrialização no Brasil (1930-1960). Rio de Janeiro: Paz e Terra, 1985.

ERREYGERS, Guido. "Economics in Belgium". IN: The New Palgrave Dictionary of Economics. Online Edition. Palgrave Macmillan, 2009.

FANGANIELLO, Helena. Roberto Simonsen e o desenvolvimento econômico. São Paulo: FEA/USP, 1970.

FAUSTO, Boris. [1969] A revolução de 1930: historiografia e história. 16 ed. 1997.

História do Brasil. 13. ed. São Paulo: Edusp, 2009.

O pensamento nacionalista autoritário. Rio de Janeiro: Jorge Zahar, 2001.

FLANDREAU, Marc. Money doctors: the experience of international financial advising 1850-2000. New York: Routledge, 2003. 
FONSECA, Pedro Cezar Dutra. Vargas: o capitalismo em construção. Rio de Janeiro: Brasiliense, 1987.

"Sobre a intencionalidade da Política Industrializante do Brasil na Década de 1930". IN: Revista de Economia Política, v. 23, n.1(89), jan-mar/2003.

FRITSCH, Winston, External constraints on economic policy in Brazil (1889-1930). Houndmills: The Macmillan Press, 1988.

FRITSCH, Winston e FRANCO, Gustavo. "Aspects of the Brazilian experience under the gold standard". Texto para discussão $\mathrm{n}^{\circ}$ 286. Rio de Janeiro: Departamento de Economia/PUC-Rio, 1992.

FURTADO, Celso. Formação econômica do Brasil. [1959]. 34 ed. São Paulo: Companhia das Letras, 2007. O mito do desenvolvimento econômico. Rio de Janeiro: Paz e Terra, 1974.

GORENDER, Jacob. "A participação do Brasil na Segunda Guerra Mundial e suas consequências”. IN: SZMRECSÁNYI, Tamás e GRANZIERA, Rui G. (org.). Getúlio Vargas e a economia contemporânea. 2. ed. São Paulo: Hucitec, 2004.

GOUREVITCH, Peter. Politics in hard times. London: Cornell University, 1986.

GRAMSCI, Antonio. Cuadernos de la cárcel. Tomo II. Caderno 4. 2. ed. México, D.F.: Ediciones Era, 1999.

GROSSMAN, Gregory; GRETHER, Ewald T.; LETICHE, John. "1985, University of California: In Memoriam." Berkeley: University of California Academic Senate, 1985. Disponível em: < http://texts.cdlib.org/view?docId=hb4d5nb20m\&doc.view= frames\&chunk.id=div00092\&toc.depth=1\&toc.id= >. Acesso em: 28/09/2013.

GUERREIRO RAMOS, Alberto. A crise do poder no Brasil. Rio de Janeiro: Zahar, 1961.

HILTON, Stanley. O Brasil e as Grandes Potências: os aspectos políticos da rivalidade comercial, 1930-1939. Rio de Janeiro: Civilização Brasileira, 1977.

HOBSBAWM, Eric. A era dos impérios: 1875-1914. 3. ed. Rio de Janeiro: Paz e Terra, 1988. 1995. A era dos extremos: o breve século XX (1914-1991). São Paulo: Cia. das Letras,

IGLÉSIAS, Francisco. “Aspectos políticos e econômicos do Estado Novo". IN: SZMRECSÁNYI e GRANZIERA, 2004.

KELLER, Vilma. "Eugênio Gudin". IN: Dicionário histórico-biográfico brasileiro: pós1930. $2^{\mathrm{a}}$ edição. Rio de Janeiro: FGV/CDPDOC, 2001.

KOJIMA, Shuichi. "Exiled Russian economists and the USSR: Brutzkus and Prokopovich". IN: BARNETT, Vincent e ZWEYNERT, Joachim (ed.). Economics in Russia: studies in intellectual history. Aldershot: Ashgate Publishing, 2008. 
LAMOUNIER, Bolívar. "Formação de um pensamento autoritário na Primeira República, uma interpretação". IN: História geral da civilização brasileira, tomo 3, volume 2. São Paulo: Difel, 1977.

LANNA, Ana Lúcia Duarte. “A transformação urbana: Santos 1870-1920”. IN: Revista USP. n. 41, março-maio. São Paulo: USP, 1999.

LEME, Marisa Saenz. O pensamento industrial no Brasil (1919-1945). São Paulo: FFLCH/USP, 1977. Tese de Doutorado.

LEOPOLDI, Maria Antonieta Parahyba. Política e interesses na industrialização brasileira. São Paulo: Paz e Terra, 2000.

LESSA, Carlos. Quinze anos de política econômica. $4^{\mathrm{a}}$ edição. São Paulo: Brasiliense, 1983

LIEBICH, André. From the other shore: Russian social-democracy after 1921. Cambridge (Massachusets): Harvard Universiy Press, 1999.

LIMA, Heitor Ferreira. Mauá e Roberto Simonsen: dois pioneiros do desenvolvimento. São Paulo: Edaglit, 1963. Ômega, 1976.

3 industrialistas brasileiros: Mauá, Rui Barbosa, Simonsen. São Paulo: AlfaHistória do pensamento econômico no Brasil. São Paulo: Cia. Editora Nacional, 1978.

LIMA, Danilo Barolo Martins de. A hegemonia como processo: elite burocrática, ideias econômicas e a conformação de grupos de interesse sobre o Tratado de Comércio Brasil-EUA (1935). IN: VI Encontro Nacional de Pós-Graduação em História Econômica/ABPHE. São Paulo: ABPHE, 2012.

LIMONGI, Fernando. "A Escola Livre de Sociologia e Polítca em São Paulo". IN: MICELI, Sérgio. História das ciências sociais no Brasil. São Paulo: Vértice/IDESP, 1989.

LOVE, Joseph. A locomotiva: São Paulo e a federação brasileira (1889-1937). Rio de Janeiro: Paz e Terra, 1982.

A construção do Terceiro Mundo: teorias do subdesenvolvimento na Romênia e no Brasil. Rio de Janeiro: Paz e Terra, 1998.

"Economic ideas and ideologies in Latin America since 1930". IN: Cambridge Histories Online. Cambridge University Press, 2008. Disponível em: <http://histories.cambridge.org>. Acesso em: 29/04/2011.

LUZ, Nícia Vilela. A luta pela industrialização do Brasil: 1808-1930. 2. ed. São Paulo: AlfaÔmega, 1975.

MACKIE, Colin. "A directory of British diplomats. 1900-2011”. Disponível em: < http://www.gulabin.com/ >. Acesso em: 26/08/2013. 
MARINGONI, Gilberto. "Liberalismo radical". IN: TEIXEIRA, Aloísio; MARINGONI, Gilberto; e GENTIL, Denise Lobato. Desenvolvimento: o debate pioneiro de 1944-1945. Brasília: IPEA, 2010.

MAZA, Fábio. O idealismo prático de Roberto Simonsen: ciência, tecnologia e indústria na construção da nação. São Paulo: Instituto Roberto Simonsen, 2004

MOURA, Gerson. Autonomia na dependência: a política externa brasileira de 1935 a 1942. Rio de Janeiro: Nova Fronteira, 1980.

NENOVSKY, Nikolay. Exchange Rates and Inflation: France and Bulgaria in the Interwar Period and the Contribution of Albert Aftalion (1874-1956). Sofia: National Bank of Bulgaria, 2006.

ORENSTEIN, Luiz e SOCHACZEWSKY, Antonio Claudio. "Democracia com Desenvolvimento". IN: ABREU, Marcelo de Paiva. Ordem do progresso; cem anos de política econômica republicana 1889-1989. Rio de janeiro: Elsevier, 1990.

PERICÁS, Luiz Bernardo. "José Carlos Mariátegui e o Brasil”. IN: Estudos avançados. (digital). vol. 24, n. 68, 2010.

PERISSINOTTO, Renato M. Classes dominantes e hegemonia na República Velha. Campinas: Ed. da Unicamp, 1994.

RODRIGUES, Carlos Henrique Lopes. A questão do protecionismo no debate entre Roberto Simonsen e Eugênio Gudin. Campinas: Unicamp. 2005. Dissertação de mestrado.

ROLL, Eric. Historia de las doctrinas económicas. México, D.F.: Fondo de Cultura Económica, 1971.

SAES, Alexandre Macchione. Conflitos do capital. Bauru: Edusc, 2010.

SAES, Alexandre Macchione; CYTRYNOVICZ, Monica Mussati; CYTRYNOVICZ, Roney. História da Federação do Comércio do Estado de São Paulo. Fecomércio 70 anos. São Paulo: Federação do Comércio, 2008.

SAES, Alexandre Macchione; CYTRYNOVICZ, Roney; SAES, Beatriz; HESPANHOL, Giancarlo; BRUZZI CURI, Luiz Felipe. FIPE 40 anos. São Paulo: FIPE, 2014. (no prelo)

SAES, Flávio Azevedo Marques de. "Industrialização e desenvolvimento na perspectiva de duas gerações de pensadores brasileiros: Roberto Simonsen e Celso Furtado". IN: COELHO, Francisco da Silva e GRANZIERA, Rui Guilherme. Celso Furtado e a formação econômica do Brasil: Edição Comemorativa dos 50 Anos de Publicação (1959-2009). São Paulo: Atlas, 2009.

SANTA ROSA, Virgínio. [1933]. O sentido do tenentismo. 3. ed. São Paulo: Alfa-Ômega, 1976.

SANTOS, Maria Cecília Loschiavo dos. Escola Politécnica da Universidade de São Paulo (1894-1984). São Paulo: Reitoria da USP/EPUSP, 1985. 
SCHUMPETER, Joseph Alois. [1954]. História da análise econômica. volumes 1, 2 e 3. Rio de Janeiro: Fundo de Cultura, 1964.

SCREPANTI, Ernesto e ZAMAGNI, Stefano. An outline of the history of economic thought. 2. ed. Oxford: Oxford University Press, 2005

SEITENFUS, Ricardo. O Brasil vai à guerra. 3. ed. Barueri: Manole, 2003.

SODRÉ, Nelson Werneck. História da burguesia brasileira. 3. ed. Rio de Janeiro: Civilização Brasileira, 1976.

SOUZA, Maria do Carmo Campello de. "O processo político partidário na Primeira República". IN: MOTA, Carlos Guilherme (org.). Brasil em perspectiva. São Paulo: AlfaÔmega, 1976.

SILVA, Marina Correia Vaz. Da maria-fumaça à fumaça das fábricas - a ELSP de São Paulo. São Paulo: Faculdade de Educação/USP, 1994. Tese de Doutorado.

SUZIGAN, Wilson. Indústria brasileira: origem $e$ desenvolvimento. São Paulo: Hucitec/Unicamp, 2000.

SZMRECSÁNYI, Tamás e GRANZIERA, Rui G. (org.). Getúlio Vargas e a economia contemporânea. 2. ed. São Paulo: Hucitec, 2004.

TEIXEIRA, Palmira Petratti. A fábrica do sonho: trajetória do industrial Jorge Street. Rio de Janeiro: Paz e Terra, 1990.

TOTA, Antonio Pedro. O imperialismo sedutor: a americanização do Brasil na época da Segunda Guerra. São Paulo: Companhia das Letras, 2000.

VIANNA, Sérgio Besserman. "Política econômica externa e industrialização: 1946-1951". IN: ABREU, Marcelo de Paiva (org.). Ordem do progresso; cem anos de política econômica republicana 1889-1989. Rio de janeiro: Elsevier, 1990.

WEFFORT, Francisco. "O populismo na política brasileira". IN: FURTADO, Celso (org.). Brasil: tempos modernos. 2. ed. Rio de Janeiro: Paz e Terra, 1977. 
ANEXOS 


\section{Anexo I.}

Tabela dos autores citados por Roberto Simonsen em História econômica do Brasil. As páginas de citações referem-se à edição de 1978, da Companhia Editora Nacional. Na última coluna à direita, indica-se se o livro pertence ou não à Coleção Roberto Simonsen. As datas indicadas entre parênteses foram determinadas posteriormente, não sendo indicadas por Simonsen em seu livro.

\begin{tabular}{|c|c|c|c|c|c|}
\hline Autor & Obra & Ano & Outras informações & Páginas da citação & $\begin{array}{l}\text { Coleção Roberto } \\
\text { Simonsen }\end{array}$ \\
\hline "Brandônio" & Diálogo das Grandesas do Brasil & ? (1930) & $\begin{array}{l}\text { Escrito em 1618, } \\
\text { introdução de Capistrano } \\
\text { de Abreu. }\end{array}$ & 54,$101 ; 110 ; 148$ & $\begin{array}{l}\text { Coleção Roberto } \\
\text { Simonsen }\end{array}$ \\
\hline $\begin{array}{l}\text { A. César Ferreira } \\
\text { Reis }\end{array}$ & História do Amazonas & ? & & $306 ; 311 ; 338$ & \\
\hline $\begin{array}{l}\text { A. de Morais } \\
\text { Carvalho }\end{array}$ & Companhias de Colonização & ? & & 355 & \\
\hline $\begin{array}{l}\text { A. K. } \\
\text { Manchester }\end{array}$ & $\begin{array}{l}\text { The British Proeminence in Brasiil, } \\
\text { and its Decline }\end{array}$ & ? & & 396 & \\
\hline A. Kirkpatrick & Los Conquistadors Espangnols & ? (1935) & Paris: Payot, 1935. & $131 ; 304 ; 325$ & $\begin{array}{l}\text { Coleção Roberto } \\
\text { Simonsen }\end{array}$ \\
\hline A. P. Newton & $\begin{array}{l}\text { The European Nations in the West } \\
\text { Indies }\end{array}$ & ? & & 129 & \\
\hline Adrien Balbi & $\begin{array}{l}\text { Essai Statistique du Royaume du } \\
\text { Portugal et Algarves }\end{array}$ & 1821 & & $112 ; 362 ; 420$ & \\
\hline Afonso Taunay & São Paulo Seiscentista & ? (1926) & São Paulo: Ideal, 1926. & 213 & \\
\hline Afonso Taunay & $\begin{array}{l}\text { História Geral das Bandeiras } \\
\text { Paulistas }\end{array}$ & ? (1924) & & $218 ; 219$ & $\begin{array}{l}\text { Coleção Roberto } \\
\text { Simonsen }\end{array}$ \\
\hline Afonso Taunay & São Paulo no Século XVI & $?(1921)$ & Tours: Ed. Arrault, 1921. & 207 & \\
\hline Afonso Taunay & Propagação da Cultura Cafeeira & ? & & 436 & \\
\hline $\begin{array}{l}\text { Alcântara } \\
\text { Machado }\end{array}$ & Vida e morte do bandeirante & ? (1930) & $\begin{array}{l}\text { Rio de Janeiro: Revista } \\
\text { dos Tribunais, } 1930 .\end{array}$ & $211 ; 213 ; 220 ; 222$ & $\begin{array}{l}\text { Coleção Roberto } \\
\text { Simonsen }\end{array}$ \\
\hline $\begin{array}{l}\text { Alexandre del } \\
\text { Mar }\end{array}$ & History of the Precious Metals & & & 284 & \\
\hline $\begin{array}{l}\text { Alfredo Ellis } \\
\text { Júnior }\end{array}$ & $\begin{array}{l}\text { O Bandeirismo Paulista e o Recuo } \\
\text { do Meridiano }\end{array}$ & ? (19--) & $\begin{array}{l}\text { São Paulo: Typ. } \\
\text { Piratininga, 19-- }\end{array}$ & 217 & $\begin{array}{l}\text { Coleção Roberto } \\
\text { Simonsen }\end{array}$ \\
\hline Alfredo Pimenta & D. João III e os Franceses & 1936 & & 85 & \\
\hline $\begin{array}{l}\text { André João } \\
\text { Antonil (João } \\
\text { Antônio } \\
\text { Andreoni) }\end{array}$ & Cultura e opulência do Brasil & 1711 & $\begin{array}{l}\text { Nota de rodapé relevante } \\
\text { p. } 104 . \text { Documento } \\
\text { reeditado várias vezes, a } \\
\text { mais próxima de } \\
\text { Simonsen em 1923, em } \\
\text { São Paulo. }\end{array}$ & $\begin{array}{r}104 ; 109 ; 110 ; 154 \\
164 ; 167\end{array}$ & \\
\hline Armitage & History of Brazil & $?$ & & 434 & \\
\hline $\begin{array}{l}\text { Augusto de } \\
\text { Carvalho }\end{array}$ & Brasil. Colonização e Imigração & $?$ & & 415 & \\
\hline $\begin{array}{l}\text { Azevedo } \\
\text { Marques }\end{array}$ & $\begin{array}{l}\text { Apontamentos Históricos da } \\
\text { Província de São Paulo }\end{array}$ & ? & & 213 & \\
\hline Benedito Calixto & Capitanias paulistas & $?$ & & 206 & \\
\hline Bento Carqueja & Capitalismo Moderno em Portugal & 1908 & & 267 & $\begin{array}{l}\text { Coleção Roberto } \\
\text { Simonsen }\end{array}$ \\
\hline Bertrand Russell & $\begin{array}{l}\text { Liberdade e Organização (1814- } \\
\text { 1914) }\end{array}$ & ? & $\begin{array}{l}\text { Publicado no Brasil pela } \\
\text { Cia. Editora Nacional }\end{array}$ & 142 & \\
\hline Borges Fortes & Cristóvão Pereira & $?$ & & $175 ; 179$ & \\
\hline Borges Fortes & Troncos seculares & 1931 & & 415 & \\
\hline C. R. Fay & $\begin{array}{l}\text { Great Britain from Adam Smith to } \\
\text { the Present Day }\end{array}$ & ? & & 65 & \\
\hline
\end{tabular}




\begin{tabular}{|c|c|c|c|c|c|}
\hline $\begin{array}{l}\text { Capistrano de } \\
\text { Abreu }\end{array}$ & Capítulos de História Colonial & ? (1934) & $\begin{array}{l}\text { Rio de Janeiro: Briguiet, } \\
1934 .\end{array}$ & $\begin{array}{r}153 ; 154 ; 157 ; 304 ; \\
336\end{array}$ & $\begin{array}{l}\text { Coleção Rpberto } \\
\text { Simonsen }\end{array}$ \\
\hline $\begin{array}{l}\text { Capistrano de } \\
\text { Abreu }\end{array}$ & $\begin{array}{l}\text { Os Caminhos Antigos e do } \\
\text { Povoamento do Brasil }\end{array}$ & $?$ & & 237 & \\
\hline Carlos Pereira & Breve História da América & $?$ & & 139 & \\
\hline Castro Carreira & $\begin{array}{l}\text { História Financeira do Império do } \\
\text { Brasil }\end{array}$ & $?$ & & 422 & \\
\hline $\begin{array}{l}\text { Charles } \\
\text { Coquelin }\end{array}$ & Companhias Privilegiadas & $?$ & & 356 & \\
\hline Chateaubriand & Estudos Históricos & $?$ & & 137 & \\
\hline $\begin{array}{l}\text { Contreras } \\
\text { Rodrigues }\end{array}$ & $\begin{array}{l}\text { Traços da Economia Social e } \\
\text { Política do Brasil Colonial }\end{array}$ & $?$ & & $166 ; 175 ; 370 ; 374$ & \\
\hline Costa Lobo & $\begin{array}{l}\text { História da Sociedade em Portugal } \\
\text { no século XV }\end{array}$ & $?$ & & 65 & \\
\hline Damião Peres & História de Portugal & $?$ & & $356 ; 361$ & \\
\hline D'Avenel & $\begin{array}{l}\text { La Fortune Privée à Travers Sept } \\
\text { Siècles }\end{array}$ & 1895 & & 64 & \\
\hline David Lopes & $\begin{array}{l}\text { A Expansão da Língua Portuguesa } \\
\text { no Oriente nos Séculos XVI, XVII e } \\
\text { XVIII }\end{array}$ & 1936 & & 40 & \\
\hline Edgar Prestage & The Portuguese Pioneer & 1933 & & 45 & \\
\hline $\begin{array}{l}\text { Edmund O. von } \\
\text { Lipmann }\end{array}$ & História do açúcar & $?$ & & 117 & \\
\hline $\begin{array}{l}\text { Eduardo Castro } \\
\text { Almeida }\end{array}$ & $\begin{array}{l}\text { inventário de documentos do } \\
\text { Arquivo da Marinha e Ultramar }\end{array}$ & $?$ & & 173 & \\
\hline Eschwege & Pluto Brasiliensis & $?$ & $\begin{array}{l}\text { tradução de Rodolfo } \\
\text { Jacob }\end{array}$ & $282 ; 283 ; 284 ; 294$ & \\
\hline $\begin{array}{l}\text { Estêvão Pereira, } \\
\text { S.J. }\end{array}$ & $\begin{array}{l}\text { Descrezão da fazenda que o } \\
\text { Collegio de Santo Antão tem no } \\
\text { Brasil e seus rendimentos }\end{array}$ & 1635 & $\begin{array}{l}\text { Mandado imprimir por } \\
\text { Afonso de Taunay, tomo } \\
\text { IV dos Anais do Museu } \\
\text { Paulista }\end{array}$ & $102 ; 151$ & \\
\hline $\begin{array}{l}\text { Euclides da } \\
\text { Cunha' }\end{array}$ & Da independência à República & $?$ & & & \\
\hline Ferdinand Lot & $\begin{array}{l}\text { La Fin du Monde Antique e le } \\
\text { Début du Moyen }\end{array}$ & $?$ & & 141 & \\
\hline $\begin{array}{l}\text { Fortunato de } \\
\text { Almeida }\end{array}$ & $\begin{array}{l}\text { Subsídios para a História } \\
\text { Econômica de Portugal }\end{array}$ & $?$ & & 354 & \\
\hline $\begin{array}{l}\text { Francisco } \\
\text { Antônio Correia }\end{array}$ & História Econômica de Portugal & $?$ & & $360 ; 409$ & \\
\hline $\begin{array}{l}\text { Frei Vicente do } \\
\text { Salvador }\end{array}$ & História do Brasil (1500-1627) & 1918 & $\begin{array}{l}\text { escrito em 1627, } \\
\text { introdução de Capistrano } \\
\text { de Abreu }\end{array}$ & $\begin{array}{l}\text { 92; } 99 \text { (longa } \\
\text { citação); } 204\end{array}$ & $\begin{array}{l}\text { Coleção Roberto } \\
\text { Simonsen }\end{array}$ \\
\hline $\begin{array}{l}\text { G. Renard et G. } \\
\text { Wenlerse }\end{array}$ & Le travail dans l'Europe Moderne & $?$ & & 141 & \\
\hline G. T. Surface & The Story of Sugar & 1916 & & 115 & \\
\hline $\begin{array}{l}\text { Gentil de Assis } \\
\text { Moura }\end{array}$ & As bandeiras paulistas & 1914 & R.I.H.R.J., tomo especial & 237 & \\
\hline George Scelle & La Traite Negrière & ? (1906) & & $54 ; 129$ & $\begin{array}{l}\text { Coleção Roberto } \\
\text { Simonsen e } \\
\text { bibliotecas USP }\end{array}$ \\
\hline Gilberto Freyre & Casa Grande e Senzala & $?(1936)$ & & $99 ; 131 ; 132$ & \\
\hline Gino Carli & O açucar na economia nacional & $?$ & & 115 & \\
\hline $\begin{array}{l}\text { Gonzalo de } \\
\text { Reparaz }\end{array}$ & Historia de la Colonización & $?$ & & 37 & \\
\hline Henderson & A History of the Brazil & 1821 & & & \\
\hline Henri Raffard & Indústria Sacarífera no Brasil & $?$ & & 151 & \\
\hline
\end{tabular}




\begin{tabular}{|c|c|c|c|c|c|}
\hline $\begin{array}{l}\text { Henrique } \\
\text { Pinheiro de } \\
\text { Vasconcelos }\end{array}$ & $\begin{array}{l}\text { Primeiros Passos do Brasil- } \\
\text { econômico }\end{array}$ & $?$ & & 431 & \\
\hline Horace Say & $\begin{array}{l}\text { Histoire des relations commerciales } \\
\text { entre la France et le Brésil }\end{array}$ & $?$ & & 440 & \\
\hline Humboldt & $\begin{array}{l}\text { Essai Politique de la Nouvelle } \\
\text { Espagne }\end{array}$ & 1811 & & $251 ; 252 ; 255 ; 256$ & \\
\hline Humbolt & $\begin{array}{l}\text { Examen Critique de l'Histoire et de } \\
\text { la Géographie du N. Continent }\end{array}$ & $?$ & & 54 & \\
\hline $\begin{array}{l}\text { J. F. de Almeida } \\
\text { Prado }\end{array}$ & $\begin{array}{l}\text { Primeiros Povoadores do Brasil } \\
(1500-1530)\end{array}$ & 1966 & & $149 ; 205$ & \\
\hline Jayme Cortesão & História de Portugal & $?$ & Portucalense Editora & $86 ; 181$ & \\
\hline $\begin{array}{l}\text { João Batista de } \\
\text { Aguirra }\end{array}$ & & & $\begin{array}{l}\text { R.I.H. de São Paulo, tomo } \\
25\end{array}$ & 215 & \\
\hline $\begin{array}{l}\text { João Cabral do } \\
\text { Nascimento }\end{array}$ & $\begin{array}{l}\text { Documento para a História das } \\
\text { Capitanias da Madeira }\end{array}$ & 1930 & & 97 & \\
\hline $\begin{array}{l}\text { João Francisco } \\
\text { de Lisboa }\end{array}$ & História do Maranhão & $?$ & & 311 & \\
\hline $\begin{array}{l}\text { João Lúcio de } \\
\text { Azevedo }\end{array}$ & Épocas de Portugal Econômico & $?$ & & $\begin{array}{r}26 ; 65 ; 81 ; 263 ; \\
366 ; 369 ; 432\end{array}$ & \\
\hline $\begin{array}{l}\text { João Lúcio de } \\
\text { Azevedo }\end{array}$ & História de Portugal & & Portucalense Editora & 111 & \\
\hline $\begin{array}{l}\text { João Lúcio de } \\
\text { Azevedo }\end{array}$ & Os Jesuítas no Grão-Pará & $?$ & & $\begin{array}{r}309 ; 317 ; 319 ; 327 ; \\
330 ; 334 ; 339\end{array}$ & \\
\hline João Ribeiro & $\begin{array}{l}\text { Rebelião contra o monpólio. } \\
\text { Beckmann }\end{array}$ & $?$ & & 319 & \\
\hline Joaquim Nabuco & $\begin{array}{l}\text { A Bacia do Amazonas, 1ạ Memória } \\
\text { sobre o litígio anglo-brasileiro }\end{array}$ & $?$ & & 303 & \\
\hline $\begin{array}{l}\text { Knight, Barnes e } \\
\text { Flügel }\end{array}$ & Economic History of Europe & 1928 & & $28 ; 249 ; 254 ; 268$ & \\
\hline L. Simonin & L'or et l'argent & 1880 & & $270 ; 285$ & \\
\hline La Condamine & $\begin{array}{l}\text { Relation Abregée d'um Voyage fait } \\
\text { dans l'interieur de l'Amérique } \\
\text { Meridionale }\end{array}$ & $?$ & & 328 & \\
\hline Lemos Brito & $\begin{array}{l}\text { Pontos de partida para História } \\
\text { Econômica do Brasil }\end{array}$ & $?$ & & $393 ; 439$ & \\
\hline $\begin{array}{l}\text { Louis de } \\
\text { Freycinet }\end{array}$ & Voyage autour du monde & 1825 & Paris, 1825. & $420 ; 437$ & \\
\hline $\begin{array}{l}\text { Luís Figueiredo } \\
\text { Falcão }\end{array}$ & $\begin{array}{l}\text { Livro de toda a fazenda e Real } \\
\text { Patrimônio }\end{array}$ & $?$ & & 365 & \\
\hline $\begin{array}{l}\text { M. E. Gomes de } \\
\text { Carvalho }\end{array}$ & D. João III e os Franceses & 1909 & & 56 & \\
\hline M. Gorceix & Minéralogie. Le Brésil & 1899 & & 287 & \\
\hline $\begin{array}{l}\text { Machado de } \\
\text { Oliveira }\end{array}$ & & ? & R.I.H.S.P., tomo 18 & 234 & \\
\hline Manuel Barata & $\begin{array}{l}\text { A Jornada de Francisco Caldeira } \\
\text { Castelo Branco }\end{array}$ & $?$ & & 307 & \\
\hline Manuel Barata & $\begin{array}{l}\text { A Antiga Produção e Exportação do } \\
\text { Pará }\end{array}$ & $?$ & & 346 & \\
\hline Maria Graham & ? (Journal of a voyage to Brazil) & 1824 & & 348 & \\
\hline $\begin{array}{l}\text { Mário } \\
\text { Vasconcelos e } \\
\text { Sá }\end{array}$ & Os navios dos descobrimentos & 1984 & & 46 & \\
\hline Max Fleiuss & Apostilas de História do Brasil & 1933 & R.I.H.R.J. & 86 & FEA 981 F596 \\
\hline
\end{tabular}




\begin{tabular}{|c|c|c|c|c|c|}
\hline Melo Morais & Coreografia histórica & ? & & 311 & \\
\hline Molinari & L'Esclavage & ? & & 143 & \\
\hline Mulhall & The Dictionary of Statistics & $?$ & & 141 & \\
\hline $\begin{array}{l}\text { Navarra y } \\
\text { Lamarca }\end{array}$ & Historia Geral da América & $?$ & & 129 & \\
\hline Navarrete & Viagem de Cristóvão Colombo & $?$ & & 54 & \\
\hline Nussbaum & $\begin{array}{l}\text { A History of the Economic } \\
\text { Institutions of Modern Europe }\end{array}$ & 1933 & & 251 & \\
\hline Octave Noel & Histoire du Commerce du Monde & $?$ & & $204 ; 208$ & \\
\hline Oliveira Lima & D. João VI no Brasil, 1808-1821 & ? & & $\begin{array}{r}400 ; 402 ; 403 ; 410 ; \\
413 ; 414 ; 415 ; 416 ; \\
417 ; 418 ; 419 ; 438\end{array}$ & \\
\hline Oliveira Martins & O Brasil e as Colônias Portuguesas & ? & & 292 & \\
\hline Oliveira Viana & A evolução do povo brasileiro & $?$ & & 153 & \\
\hline Oliveira Viana & Populações Meridionais do Brasil & ? & & 211,272 & \\
\hline $\begin{array}{l}\text { Pandiá } \\
\text { Calógeras }\end{array}$ & Formação Histórica do Brasil & & $\begin{array}{l}\text { Usado para qualificar } \\
\text { Antonil }\end{array}$ & $\begin{array}{r}88 ; 104 ; 273 ; 281 ; \\
290 ; 392\end{array}$ & $\begin{array}{l}\text { Coleção Roberto } \\
\text { Simonsen }\end{array}$ \\
\hline $\begin{array}{l}\text { Pandiá } \\
\text { Calógeras }\end{array}$ & Política Exterior do Império & $\begin{array}{r}?(1927- \\
33)\end{array}$ & $\begin{array}{l}\text { São Paulo: Cia. Editora } \\
\text { Nacional, 1927-1933. }\end{array}$ & $137 ; 338$ & $\begin{array}{l}\text { Coleção Roberto } \\
\text { Simonsen }\end{array}$ \\
\hline $\begin{array}{l}\text { Pandiá } \\
\text { Calógeras }\end{array}$ & As Minas do Brasil & $\begin{array}{r}?(1904- \\
05)\end{array}$ & $\begin{array}{l}\text { Rio de Janeiro: Imprensa } \\
\text { Nacional, 1904-05. }\end{array}$ & $\begin{array}{r}282 ; 442 ; 445 ; 447 ; \\
448 ; 449\end{array}$ & \\
\hline $\begin{array}{l}\text { Pandiá } \\
\text { Calógeras }\end{array}$ & La politique monetaire du Brésil & ? (1910) & $\begin{array}{l}\text { Rio de Janeiro: } \\
\text { Imprimerie Nationale, } \\
1910\end{array}$ & $407 ; 409 ; 413 ; 439$ & $\begin{array}{l}\text { Coleção Roberto } \\
\text { Simonsen }\end{array}$ \\
\hline Paul Gaffarel & Histoire du Brésil français & 1878 & & $56 ; 58$ & \\
\hline Paulo Prado & O caminho do mar & $?$ & & 207 & \\
\hline Paulo Prado & Paulística & $?$ & & 209 & \\
\hline $\begin{array}{l}\text { Pedro de } \\
\text { Magalhães } \\
\text { Gandavo }\end{array}$ & Tratado da Terra do Brasil & $?$ & & 61 & \\
\hline $\begin{array}{l}\text { Pedro Taques } \\
\text { de Almeida Pais } \\
\text { Leme }\end{array}$ & Inf. Sobre as Minas de S. Paulo & $?$ & & 219 & \\
\hline $\begin{array}{l}\text { Perdigão } \\
\text { Malheiros }\end{array}$ & A escravidão no Brasil & $?$ & & 138 & \\
\hline Pereira Pinto & $\begin{array}{l}\text { Apontamentos de Direito } \\
\text { Internacional }\end{array}$ & ? & & 398 & \\
\hline Pierre Brizon & Histoire du Travail & $?$ & & 141 & \\
\hline Pitaval e Ganet & Mineraux et Metaux & $?$ & & 292 & \\
\hline $\begin{array}{l}\text { Quirino da } \\
\text { Fonseca }\end{array}$ & $\begin{array}{l}\text { A Caravela Portuguesa e a } \\
\text { Prioridade das Navegações } \\
\text { Henriquinas }\end{array}$ & 1934 & & 46,54 & \\
\hline Raynal & $\begin{array}{l}\text { Hist. Philosophique et Politique } \\
\text { (vol. 8) }\end{array}$ & 1792 & & 265 & \\
\hline $\begin{array}{l}\text { Roberto } \\
\text { Simonsen }\end{array}$ & $\begin{array}{l}\text { Aspectos da Política Econômica } \\
\text { Nacional }\end{array}$ & 1935 & & 406 & \\
\hline Rocha Pita & História da América Portuguesa & $\begin{array}{r}1750 \\
(1730 ?)\end{array}$ & $\begin{array}{l}\text { Documento reeditado em } \\
1880 \text { (provável consulta } \\
\text { de Simonsen) }\end{array}$ & $108 ; 358$ & \\
\hline Rocha Pombo & História do Brasil & $?$ & & $46 ; 84$ & FFLCH, IEB, etc. \\
\hline $\begin{array}{l}\text { Roërie et } \\
\text { Vivielle }\end{array}$ & Navires et Marines & 1930 & & 46 & \\
\hline Rosa Lagoa & O Brasil, Estudo Econômico & ? & & 360 & \\
\hline
\end{tabular}




\begin{tabular}{|c|c|c|c|c|c|}
\hline $\begin{array}{l}\text { Sebastião } \\
\text { Ferreira Soares }\end{array}$ & Elementos de Estatística & 1865 & & 265 & \\
\hline Sombart & Le Bourgeois & $?$ & & 268 & \\
\hline Sousa Viterbo & $\begin{array}{l}\text { Trabalhos Náuticos dos } \\
\text { Portugueses nos séculos XVI e XVII }\end{array}$ & $?$ & & 54 & \\
\hline Southey & History of Brazil & $?$ & & 160 & \\
\hline $\begin{array}{l}\text { Varnhagen } \\
\text { (Porto Seguro e } \\
\text { Rodolfo Garcia) }\end{array}$ & História Geral do Brasil & ? (19--) & $\begin{array}{l}\text { São Paulo: } \\
\text { Melhoramentos, 19--. }\end{array}$ & $\begin{array}{r}80 ; 98 ; 113 ; 133 ; \\
180 ; 185 ; 286 ; 310 ; \\
373 ; 447\end{array}$ & $\begin{array}{l}\text { Coleção Roberto } \\
\text { Simonsen }\end{array}$ \\
\hline $\begin{array}{l}\text { Visconde de } \\
\text { Santarém }\end{array}$ & $\begin{array}{l}\text { Quadro elementar das relações } \\
\text { diplomáticas }\end{array}$ & $?$ & & 366 & \\
\hline Vítor Viana & Formação Econômica do Brasil & ? (1922) & & $98 ; 405 ; 435$ & $\begin{array}{l}\text { Coleção Roberto } \\
\text { Simonsen }\end{array}$ \\
\hline Warden & Histoire de l'Empire du Brésil & $?$ & & 441 & \\
\hline $\begin{array}{l}\text { Warren and } \\
\text { Pearson }\end{array}$ & $\begin{array}{l}\text { History of the English Pound } \\
\text { Sterling }\end{array}$ & $?$ & & 65 & \\
\hline $\begin{array}{l}\text { Warren and } \\
\text { Pearson }\end{array}$ & Gold and Prices & 1935 & & 254 & \\
\hline Washington Luís & $\begin{array}{l}\text { estudo sobre a vida de Raposo } \\
\text { Tavares }\end{array}$ & 1904 & $\begin{array}{l}\text { Revista do Instituto } \\
\text { Histórico e Geográfico de } \\
\text { SP }\end{array}$ & 212 & \\
\hline$?$ & $\begin{array}{l}\text { Roteiro do Maranhão a Goiás } \\
(1770-1780)\end{array}$ & $?$ & $\begin{array}{l}\text { Publicado na Revista do } \\
\text { IHGB, vol. } 62\end{array}$ & & \\
\hline ? & $\begin{array}{l}\text { Documentos Interessantes do } \\
\text { Archivo do Estado de São Paulo }\end{array}$ & $?$ & $\begin{array}{l}\text { Os ANEXOS documentais } \\
\text { aos capítulos que tratam } \\
\text { da pecuária foram } \\
\text { tirados, em sua maioria, } \\
\text { dessa publicação do } \\
\text { Arquivo do Estado de SP. }\end{array}$ & $177 ; 219 ; 223 ; 230$ & \\
\hline
\end{tabular}




\section{Anexo II.}

Reproduções de duas páginas do livro Theory of national economic planning (1944), de Carl Landauer, presente na Coleção Roberto Simonsen, com sublinhados e anotações de Roberto Simonsen.

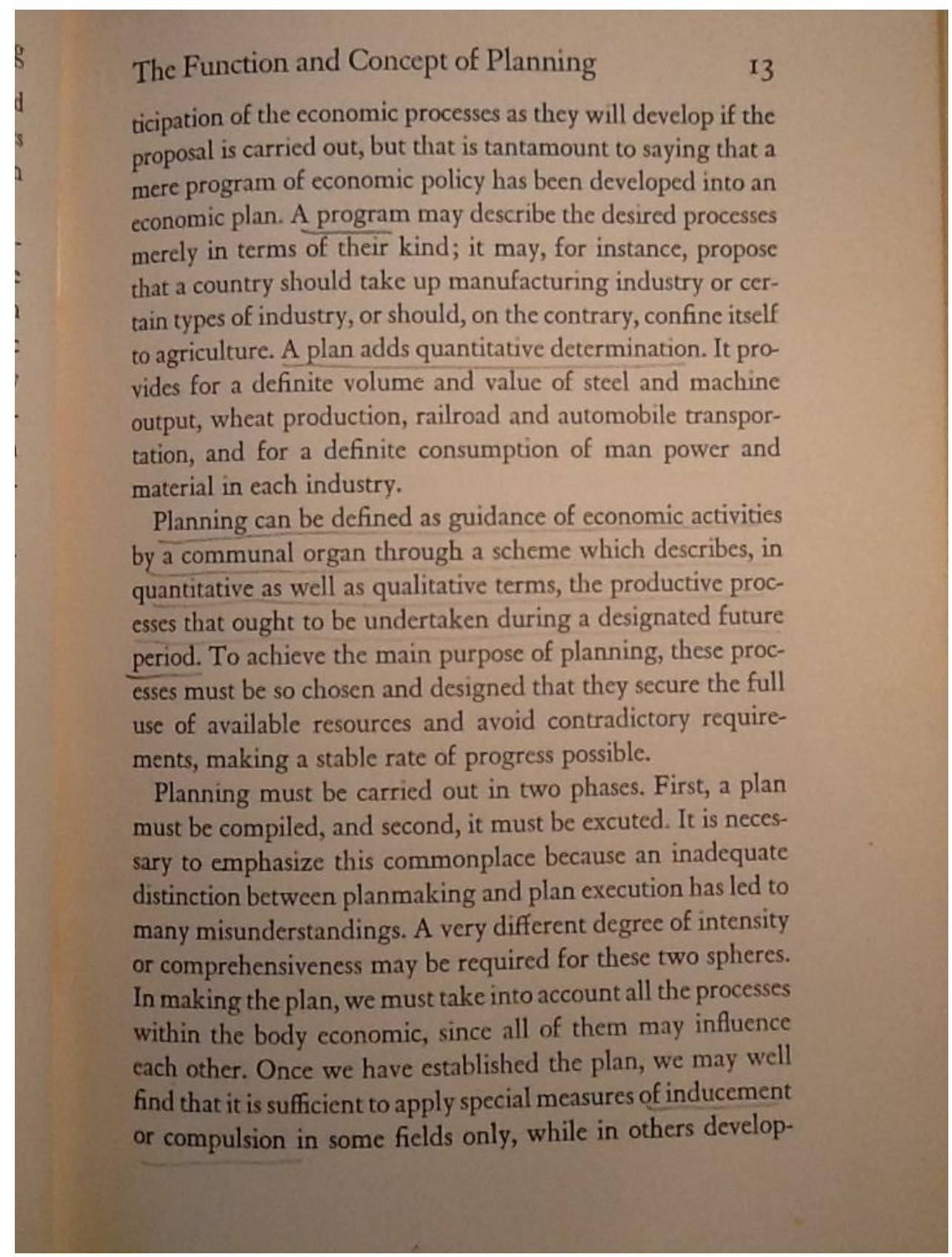

Figura 5. Página 13 do livro de Landauer.

O trecho sublinhado, como referido no texto do capítulo 3, é a definição apresentada por Simonsen em sua segunda contribuição à controvérsia do planejamento. 


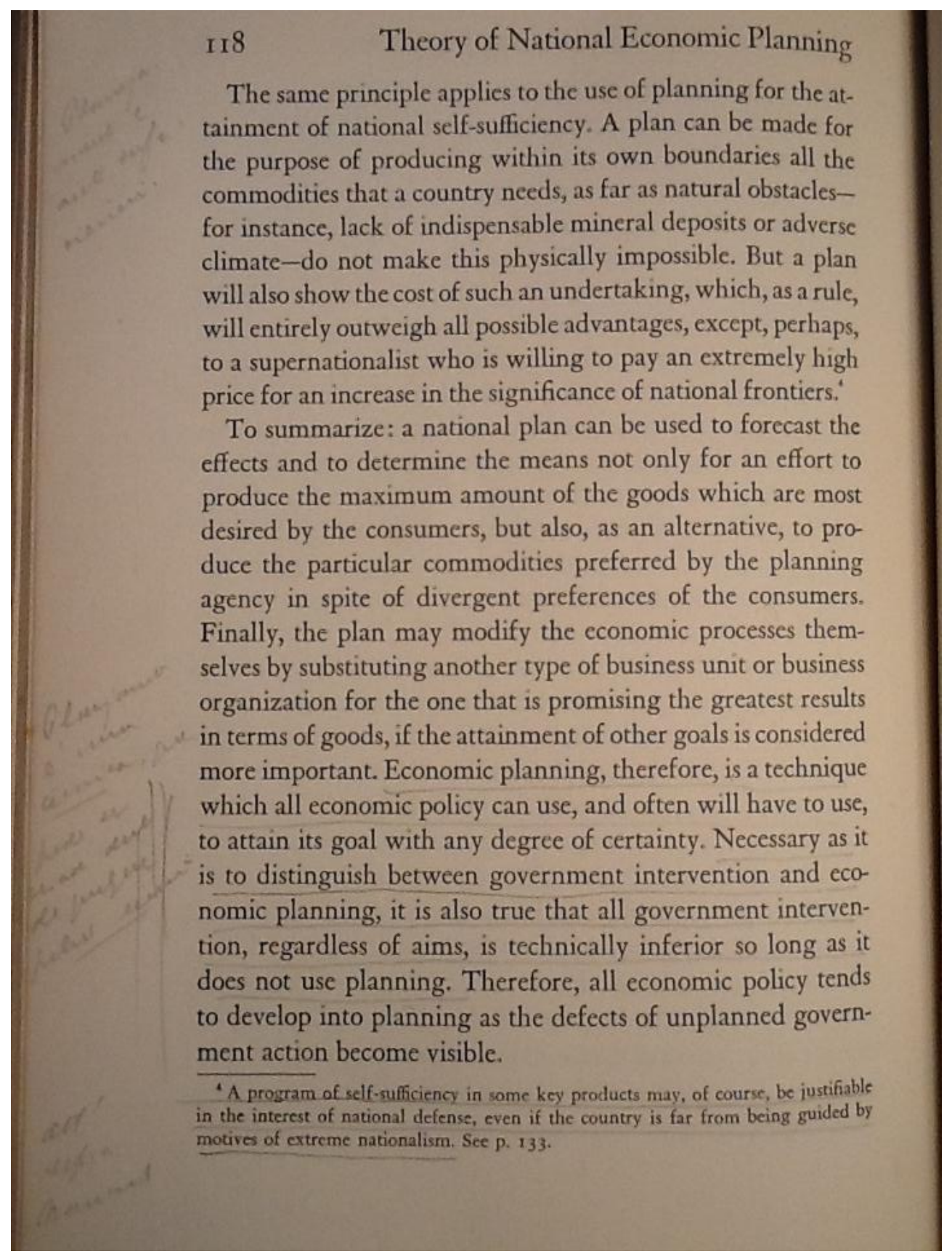

Figura 6. Página 118 do livro de Landauer.

Aqui aparece o trecho em que Landauer atribui ao planejamento o caráter de técnica, que poderia ser utilizada por quaisquer governos. A anotação de Simonsen à margem diz: "O planejamento é uma técnica, que pode ser usada dentro de qualquer política econômica". 